MELISSA DI LASCIO SAMPAIO

\title{
A ADOÇÃO INTER-RACIAL E O DESENVOLVIMENTO SÓCIO-PESSOAL RECÍPROCO
}

Dissertação de Mestrado

Orientadora:

Prof. Associada ELZA A. P. CUNHA BOITEUX

FACULDADE DE DIREITO DA UNIVERSIDADE DE SÃO PAULO ÁREA DE CONCENTRAÇÃO: DIREITOS HUMANOS

SÃO PAULO

2014 


\section{A ADOÇÃO INTER-RACIAL E O DESENVOLVIMENTO SÓCIO-PESSOAL RECÍPROCO}

Dissertação de Mestrado apresentada ao Departamento de Filosofia e Teoria Geral do Direito da FACULDADE DE DIREITO DA UNIVERSIDADE DE SÃO PAULO LARGO SÃO FRANCISCO, como exigência parcial para a obtenção do título de Mestre em Direito, sob orientação da Professora Associada Elza Antonia Pereira Cunha Boiteux. 
MELISSA DI LASCIO SAMPAIO

\section{A ADOÇÃO INTER-RACIAL E O DESENVOLVIMENTO SÓCIO-PESSOAL RECÍPROCO}

\section{TERMO DO EXAME DE DEFESA}

Defesa realizada em ___

BANCA EXAMINADORA

Profa. Associada Elza A. Pereira Cunha Boiteux (orientadora)

Universidade de São Paulo

Universidade de São Paulo

Examinador Externo 


\section{Dedicatória}

À memória de Maria Antônia de Oliveira, prova de que o amor ultrapassa as barreiras da raça.

À Victoria, com amor. 


\section{SUMÁRIO}

INTRODUÇÃO

\section{CAPÍTULO 1 DOS DIREITOS FUNDAMENTAIS}

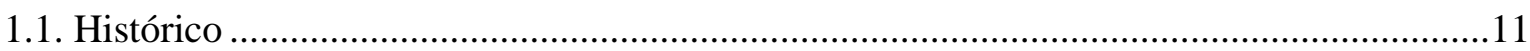

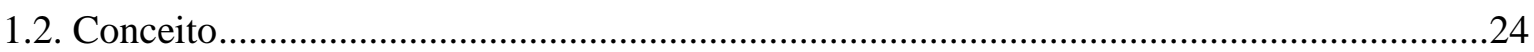

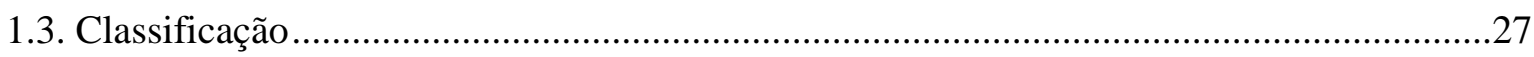

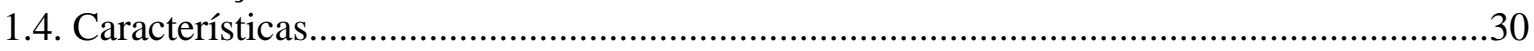

\section{CAPÍTULO 2 ABERTURA DOS DIREITOS FUNDAMENTAIS: TRATADOS INTERNACIONAIS}

2.1. Conceito.

2.2. Eficácia das normas dos tratados internacionais incorporados ao direito interno ................46

2.3. Tratados internacionais de direitos humanos: hierarquia normativa e interpretação ...........48

2.4. A interpretação dos tratados internacionais de direitos humanos e o diálogo das Cortes ..........56

2.5. Proteção internacional dos direitos das crianças e dos adolescentes ...................................60

\section{CAPÍtUlO 3 PROTEÇÃO DOS DIREITOS DAS CRIANÇAS NA ESFERA NACIONAL}

3.1. Linhas introdutórias

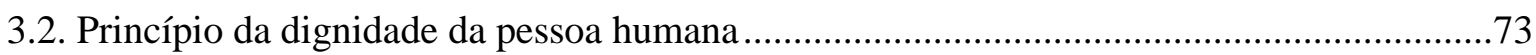

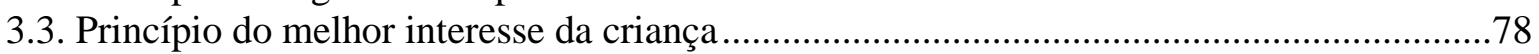

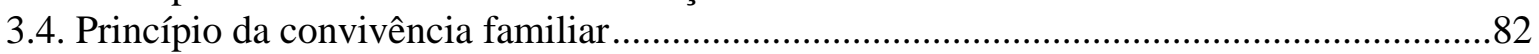

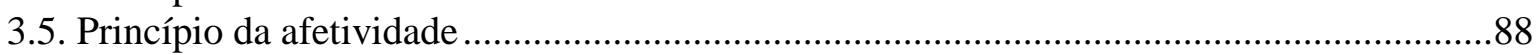

\section{CAPÍTULO 4 DO PROCESSO DE ADOÇÃO}

4.1. Breves considerações a respeito da adoção ..........................................................................97

4.2. Procedimento e peculiaridades do processo de adoção .....................................................101

4.3. Características dos adotantes, dos adotados e dos pais biológicos ..................................118

4.4. Adoção inter-racial: argumentos contrários e favoráveis à medida....................................130

4.5. O amparo psicológico como mecanismo de esclarecimento e de estímulo às adoções inter-

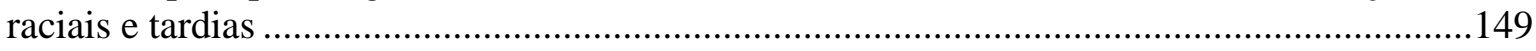

4.6. A educação em direitos humanos como mecanismo de esclarecimento e de estímulo às

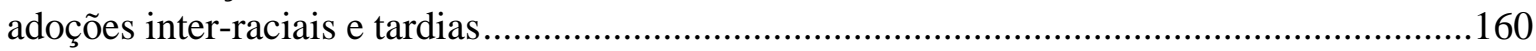

\section{CAPÍTULO 5 A ADOÇÃO INTER-RACIAL COMO MECANISMO DE DESENVOLVIMENTO PESSOAL RECÍPROCO E DE INCLUSÃO SOCIAL}

5.1. A realidade brasileira.

5.2. A adoção inter-racial como mecanismo de desenvolvimento humano recíproco ..............178

5.3. A adoção inter-racial como medida preventiva da violência e da exclusão social............188

CONCLUSÃO

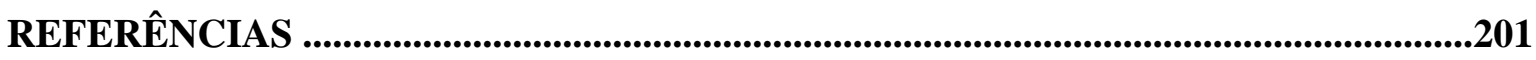




\section{RESUMO}

O presente trabalho se dedica ao estudo da adoção inter-racial, como importante mecanismo de preservação dos interesses das crianças e dos adolescentes abandonados e institucionalizados no país, dos adotantes e da sociedade em geral. A pesquisa tem início com a análise das normas nacionais e internacionais destinadas à proteção dos direitos das crianças, com especial enfoque aos princípios da dignidade da pessoa humana, do melhor interesse da criança, da convivência familiar e da afetividade. Fixado o regramento jurídico geral a respeito do tema, passa-se à análise do processo de adoção, com especial ênfase ao perfil dos interessados e à adoção inter-racial. Após detalhado estudo das teses favoráveis e contrárias a esta modalidade de adoção, com fundamento na doutrina norte-americana, comprova-se que, uma vez ultrapassados o preconceito racial e a resistência dos interessados à transparência da paternidade afetiva, a medida é extremamente vantajosa aos interesses não apenas dos adotados, como também dos adotantes, dos pais biológicos e da sociedade brasileira. Por fim, a pesquisa conclui que a adoção inter-racial, por promover um reconhecimento positivo dos envolvidos, representa importante mecanismo de inclusão social, de desenvolvimento humano, de prevenção da violência e de combate ao racismo.

Palavras-chave: Direitos humanos. Criança e adolescente. Adoção inter-racial. Desenvolvimento humano. Inclusão social. 


\begin{abstract}
The present study aims to examine transracial adoption as an important mechanism to preserve the interests of abandoned and foster care children and adolescents in the country, the adopters and society in general. The research begins with the analysis of national and international standards for the protection of children's rights, with a special focus on the principles of human dignity, the best interest of the child, family coexistence and affection. Once the general legal rules on the subject are set, the study goes forward to the analysis of the adoption process itself, with special emphasis on the profile of all the involved in the process and on transracial adoption. After a detailed study of the pros and cons of this type of adoption, based on North American doctrine, it was proven that, once overcome racial prejudice and resistance to the acceptance of affective paternity, this source is extremely advantageous to the interests of both adoptees and adopters, biological parents and Brazilian society. Finally, the research concludes that transracial adoption is an important mechanism of social inclusion, human development, violence prevention and combating racism as it promotes a positive recognition of those involved in this process.
\end{abstract}

Key-words: Human rights. Children and adolescents. Transracial adoption. Human development. Social inclusion. 


\section{INTRODUÇÃO}

De acordo com as pesquisas realizadas pelo Instituto de Pesquisa Econômica Aplicada- IPEA $(2003)^{1}$ e pela Secretaria de Assistência Social de São Paulo, ${ }^{2}$ o número de crianças institucionalizadas no país pode chegar a cem mil, distribuídas pelos 630 abrigos cadastrados pela Rede de Serviços de Ação Continuada, sendo que, deste número, pelo menos, 4.847 crianças estão abrigadas na cidade de São Paulo.

A institucionalização prolongada, em razão da ausência de formação de vínculos afetivos, permanentes e duradouros, traz consequências extremamente danosas ao desenvolvimento pessoal e social destas crianças.

Muitas são as causas que levam ao abandono e à institucionalização das crianças brasileiras, podendo ser citados como exemplos, dentre outros, a carência financeira, a desestabilidade emocional, a falta de perspectivas, a repetição de condutas negativas, a violência doméstica e o vício em substâncias entorpecentes ou em álcool. O conhecimento destas causas e das pessoas diretamente atingidas por elas é essencial para a solução do problema da institucionalização prolongada.

A Constituição Federal de 1988, inspirada na Declaração de Direitos Humanos e em outros documentos internacionais destinados à proteção dos direitos humanos, estabeleceu ser a família direito fundamental de todos os indivíduos, merecendo especial atenção do Estado.

Em cumprimento a esta norma, o legislador pátrio elaborou o Estatuto da Criança e do Adolescente- ECA, com a finalidade de preservar os interesses das crianças (aqui entendidas no sentido amplo, abrangendo também os adolescentes), não apenas no campo civil, com também no campo penal.

\footnotetext{
${ }^{1}$ INSTITUTO DE PESQUISA ECONÔMICA AVANÇADA- IPEA. Levantamento nacional dos abrigos para crianças e adolescentes da rede de Serviço de Ação Continuada (SAC). Relatório de Pesquisa n.01, Brasília: IPEA, 2003.

${ }^{2}$ SECRETARIA MUNICIPAL DE ASSISTÊNCIA SOCIAL - SAS [et al.] (2004). Reordenamento de abrigos infanto-juvenis da cidade de São Paulo: construção da política interinstitucional de defesa dos direitos de convivência familiar e comunitária das crianças e adolescentes de São Paulo. São Paulo: SAS, 2004.
} 
A este trabalho interessam especialmente os princípios voltados à proteção da criança no seio familiar (dignidade da pessoa humana, convivência familiar, melhor interesse da criança e afetividade), responsáveis pelo desenvolvimento saudável da personalidade do indivíduo.

O nosso sistema jurídico busca preservar os interesses das crianças abrigadas através da adoção de medidas tendentes à reaproximação com a sua família biológica e à reconstrução dos vínculos afetivos.

Estas medidas, entretanto, apesar de ideais, nem sempre são viáveis, quer porque os pais biológicos não tenham condições físicas e emocionais de cuidar de seus filhos, quer porque não possuam nenhum interesse pela paternidade. Dessa maneira, a recolocação destas crianças em sua família de sangue representaria riscos à integridade física, moral, emocional e espiritual das mesmas.

Em hipóteses como tais, em que a convivência destas crianças no seio de sua família de origem se mostra inviável, a adoção se mostra a medida mais indicada para a proteção dos interesses destes seres em desenvolvimento.

Neste contexto, esta pesquisa busca demonstrar que a adoção é uma alternativa não apenas válida, como também a mais adequada, para a garantia dos princípios da afetividade, do melhor interesse da criança, da convivência familiar e da dignidade da pessoa humana, sempre que for inviável a manutenção da criança em sua família de origem.

A adoção, entretanto, para que seja bem sucedida e garanta da forma mais ampla possível os interesses dos envolvidos, deve levar em consideração o perfil não apenas dos adotados, como também dos adotantes e dos pais biológicos.

Em razão do contexto histórico e econômico brasileiro, a grande maioria das crianças institucionalizadas no país é negra (em sentido lato), ao passo que a maior parte dos interessados na adoção é branca. Estes dados deixam claro que a adoção inter-racial é a que melhor atende às necessidades dos envolvidos. 
O tema da adoção inter-racial foi pouco abordado pela doutrina brasileira, muito provavelmente em razão do mito da democracia racial e da negação da existência de discriminação no país. Em razão desta ausência de produção científica, não restou a esta pesquisa senão a alternativa de utilização de dados da doutrina norte-americana, que, ao contrário da nossa, dedica-se há anos ao estudo do tema.

Após a análise da regulamentação dos direitos das crianças e dos adolescentes, no âmbito nacional e internacional (Capítulos I e II) e dos princípios voltados à proteção destes direitos (Capítulo III), este trabalho se dedica à análise do processo de adoção (Capítulo IV), com especial enfoque ao perfil dos interessados à adoção inter-racial.

Especificamente no que se refere à adoção inter-racial, esta dissertação analisa, de forma detalhada, as teses favoráveis e contrárias à medida, com a finalidade de demonstrar que esta modalidade de adoção, ademais de ser a mais adequada para a realidade brasileira, é vantajosa não apenas aos interesses das crianças envolvidas, como também aos interesses dos pais biológicos e dos adotantes.

Não se nega que a concretização da adoção inter-racial no Brasil apresenta dificuldade e desafios, em razão do preconceito racial e da resistência dos adotantes em assumirem a paternidade afetiva de forma aberta e irrestrita. Este trabalho, entretanto, demonstra que estas dificuldades podem ser ultrapassadas através da assistência social e psicológica dos diretamente interessados e da promoção da educação em direitos humanos na sociedade brasileira.

As medidas acima mencionadas, de cunho individual e coletivo, destinam-se ao preparo e ao incentivo da adoção inter-racial no país, tendo por destinatários não apenas os adotantes e os adotados, como também os pais biológicos e a sociedade. É preciso que todos os envolvidos no processo de adoção, de forma direta ou indireta, sejam preparados e instruídos a respeito da importância da paternidade afetiva e de suas particularidades.

Ultrapassados estes desafios, este trabalho demonstra, em seu Capítulo V, que a adoção inter-racial representa importante mecanismo de inclusão, por permitir às crianças institucionalizadas a retomada do convívio familiar e social e a aquisição, neste processo, de estima e de valores positivos. 
O reconhecimento, nas esferas do amor, do direito e da estima social, conforme se demonstrará neste trabalho, previne que os seres humanos adotem comportamentos violentos. Dessa maneira, em última análise, a valorização da família, através da adoção inter-racial, mostra-se como importante mecanismo de prevenção da violência no país.

Por fim, não há como se negar que a adoção inter-racial, por permitir o convívio de pessoas de raças diversas, a valorização do outro e o respeito à diferença, representa, também, importante mecanismo de combate ao racismo e à discriminação.

Todos estes aspectos positivos, de âmbito não apenas individual como coletivo, demonstram que a adoção inter-racial é uma medida extremamente vantajosa aos interesses dos envolvidos, em especial das crianças institucionalizadas e abandonadas no Brasil.

Em um âmbito mais amplo, o presente trabalho visa comprovar que a proteção da família, seja ela natural ou afetiva, é essencial para o desenvolvimento da sociedade brasileira, merecendo especial atenção do Poder Público. ${ }^{3}$

\footnotetext{
${ }^{3}$ Como bem lembrado pelo Relatório de Direitos Humanos, "As famílias são frequentemente deixadas de lado na formação das políticas públicas, não como beneficiárias, mas como protagonistas. Pensa-se muitas vezes em políticas para as famílias, mas não em políticas com as famílias, em que elas possam exercer seu papel de agente na construção do desenvolvimento humano e da justiça social no país. No debate sobre a formação de valores a família exerce papel fundamental. Quando entendemos que esses valores são formados pelas práticas e estilos parentais, como visto no Capítulo 8 deste relatório, é natural que o foco das políticas esteja na construção de vivências e experiências que promovam práticas de valores públicos. Mais ainda, quando se elegem os problemas da baixa qualidade de educação e da violência como prioritários para o desenvolvimento do país, passa a ser fundamental pensar de maneira transversal a importância da família como elemento transformador das relações sociais com impacto no que acontece nas escolas e no cotidiano de todos. A explicação é simples: a promoção de valores públicos é peça-chave na melhoria do cotidiano e da convivência nas escolas; isso pode contribuir também para a melhoria da qualidade da educação, ao fazer da escola um espaço mais atraente, motivador e acolhedor para os alunos" (ONU. Programa das Nações Unidas para o Desenvolvimento. Relatório de Desenvolvimento Humano Brasileiro 2009/2010. Brasília: PNUD, 2010. p. 208).
} 


\title{
CAPÍTULO 1 DOS DIREITOS FUNDAMENTAIS ${ }^{4}$
}

\subsection{Histórico}

O reconhecimento dos direitos fundamentais, de forma escrita e expressa, pode ser visto como uma conquista recente.

A maioria dos doutrinadores aponta a Carta Magna de 1215, documento imposto pelos barões feudais ao Rei João Sem-Terra, como o marco histórico da aceitação dos direitos fundamentais.

De acordo com os ensinamentos de Fábio Konder Comparato:

\begin{abstract}
Em que pese a sua forma de promessa unilateral, feita pelo rei, a Magna Carta constitui, na verdade, uma convenção passada entre o monarca e os barões feudais, pela qual se lhes reconheciam certos foros, isto é, privilégios especiais (...). No caso, não se tratou de delegações de poderes reais, mas sim do reconhecimento de que a soberania do monarca passava a ser substancialmente limitada por franquias ou privilégios estamentais, que beneficiavam, portanto, de modo coletivo, todos os integrantes das ordens privilegiadas. ${ }^{5}$
\end{abstract}

Percebe-se pela leitura da citação acima que a Carta Magna, ao contrário de alcançar todos os seres humanos, teve como destinatários somente a camada mais privilegiada da sociedade, motivo pelo qual não se pode atribuir-lhe caráter universal. Neste sentido:

$\mathrm{O}$ documento que a maioria dos autores considera o antecedente direto, mais remoto, das Declarações de Direitos é a Magna Carta da Inglaterra, de 1215. Na realidade, não se pode dizer que as normas da Magna Carta constituem uma afirmação de caráter universal de direitos inerentes à pessoa humana e oponíveis a qualquer governo. $\mathrm{O}$ que ela consagrou, de fato, foram os direitos dos barões e prelados ingleses, restringindo o poder absoluto do monarca. Todavia, essa afirmação de direitos, feita em caráter geral e obrigando o rei da Inglaterra no seu relacionamento com os súditos, representou um avanço, tendo fixado alguns

\footnotetext{
${ }^{4}$ Algumas das ideias defendidas neste Capítulo foram extraídas do trabalho de conclusão de curso apresentado na pós-graduação lato sensu em Direito Constitucional, intitulado "A inconstitucionalidade do processo judicial de adoção", em 2006.

${ }^{5}$ COMPARATO, Fábio Konder. A Afirmação Histórica dos Direitos Humanos. $4^{a}$ ed. São Paulo: Saraiva, 2005. p. 77.
} 
princípios que iriam ganhar amplo desenvolvimento, obtendo a consagração universal. ${ }^{6}$

Apesar de não possuir caráter universal, os ditames da Carta Magna serviram como inspiração para diversas declarações elaboradas nos anos seguintes e geraram muitos instrumentos jurídicos utilizados até os dias atuais, como é o caso do Habeas Corpus.

Nos Estados Unidos, o reconhecimento dos direitos fundamentais teve início com a Declaração de Independência, aos 04 de julho de 1776, caracterizada como o primeiro documento a afirmar os princípios democráticos na história moderna.

Ressalte-se que o conceito de democracia está intimamente ligado aos direitos fundamentais. Isto porque, a democracia pressupõe a participação direta do povo na vida política da Nação, que só se faz possível quando os indivíduos tiverem seus direitos civis e políticos garantidos pela ordem jurídica vigente. Nesse sentido:

\footnotetext{
Para que um Estado seja democrático precisa atender à concepção dos valores fundamentais de certo povo numa época determinada. Como essas concepções são extremamente variáveis de povo para povo, de época para época, é evidente que o Estado deve ser flexível, para se adaptar às exigências de cada circunstância. ${ }^{7}$
}

Dessa maneira, como bem lembrado por Fábio Konder Comparato, ${ }^{8}$ a importância histórica da Declaração de Independência dos Estados Unidos está não somente no fato de que ela reconhece a legitimidade da soberania popular, como também e principalmente na previsão de direitos inerentes a todo ser humano.

Não obstante os avanços obtidos com a Declaração de Independência, a universalidade da proteção dos direitos humanos só foi alcançada, efetivamente, com a Declaração de Direitos do Homem e do Cidadão, em 1789. Isto porque, os americanos estavam mais interessados em estabelecer seu próprio regime político do que em levar a conquista da liberdade aos demais povos.

\footnotetext{
${ }^{6}$ DALLARI, Dalmo de Abreu. Elementos da Teoria Geral do Estado. $25^{\mathrm{a}}$ ed. São Paulo: Saraiva, 2003. pp. 106-107.

${ }^{7}$ Idem, ibidem, p. 307.

${ }^{8}$ COMPARATO, Fábio Konder. A Afirmação Histórica dos Direitos Humanos. $4^{\mathrm{a}}$ ed. São Paulo: Saraiva, 2005. p. 103.
} 
Os franceses, por outro lado, tinham a intenção de promover a efetiva igualdade entre os indivíduos e grupos sociais existentes na época. Apesar do lema da Revolução Francesa ser a tríade liberdade, igualdade e fraternidade, sem sombra de dúvidas, foi a igualdade o ponto central do movimento revolucionário.

A falta de preocupação da Declaração de Independência norte-americana com o direito à igualdade se deveu ao fato de as treze colônias inglesas não terem enfrentado os problemas de desigualdade social que preocupavam a Europa na época. Muito pelo contrário, o princípio da igualdade jurídica entre os homens livres foi considerado o traço marcante da sociedade norte-americana.

Nesta linha de raciocínio, merecem destaque as lições de Fábio Konder Comparato:

\begin{abstract}
Ainda neste particular, por conseguinte, a Revolução Francesa distinguiu-se nitidamente do movimento de independência dos Estados Unidos. A sociedade norte-americana jamais conhecera as divisões estamentais ou as guerras de religião, que convulsionaram a Europa. Tirando a escravidão negra, ela era, portanto, juridicamente igualitária. Ao rejeitarem a proposta de Jefferson- esta sim revolucionária- para a imediata abolição da escravatura, os convencionais de Filadélfia puseram em marcha o processo histórico que levaria inexoravelmente à guerra civil, no século seguinte.
\end{abstract}

Os anos que seguiram estas duas importantes declarações de direitos foram marcados pela tentativa de se voltar a atenção da comunidade internacional para o $\underline{\text { ser }}$ $\underline{\text { humano, }}$ relativizando-se a até então dominante lógica de Westfália, que norteava as relações internacionais. Nesse sentido:

No século XIX as necessidades da interdependência no relacionamento entre os
Estados foram diminuindo a efetividade da lógica de Westfália e de suas normas
de mútua abstenção e propiciando normas de mútua colaboração. Este é um dos
motivos pelo qual o pós-Primeira Guerra Mundial foi além da informalidade do
equilíbrio do poder que caracterizara o Concerto Europeu. Assinalou, com a
Sociedade das Nações de 1919, uma primeira tentativa de criar um pactum
societatis (pacto de sociedade) no plano internacional. Este pactum societatis, de
vocação universal, estava voltado para regular o uso da força e evitar o que fora
a inédita surpresa técnica da destrutividade da guerra moderna. Buscou
institucionalizar a comunidade internacional, criando um tertius inter-partes
(terceiro entre as partes) por meio de organização internacional. Esta, no seu
tratado constitutivo, expressa técnicas e valores de Direito Constitucional, que
inspiraram, no século XIX, a expansão do constitucionalismo no plano interno
dos Estados. O Pacto da Sociedade das Nações teve como motivação central
propiciar a independência das nacionalidades, a segurança coletiva e a paz
individual. Entretanto, no seu contexto, em função das realidades internacionais

${ }^{9}$ COMPARATO, Fábio Konder. A Afirmação Histórica dos Direitos Humanos. $4^{\mathrm{a}}$ ed. São Paulo: Saraiva, 2005. p. 135. 
da época e dos cuidados na preservação dos valores da soberania, o papel atribuído aos direitos humanos era circunscrito. ${ }^{10}$

Observa-se, assim, que as lutas pelo reconhecimento dos direitos fundamentais que marcaram os Estados Unidos e a França, no século XVIII, e tiveram como foco os direitos civis e políticos (ainda que com enfoque diverso em cada país), ${ }^{11}$ trouxeram consequências importantes para o direito internacional, a partir do século XIX.

Tanto isso é verdade que as declarações de direitos decorrentes destas Revoluções internas mostraram a necessidade de limitação do poder do Estado, em prol do ser humano, colocando à prova as ideias de soberania absoluta até então existentes.

Foi também no século $\mathrm{XIX}^{12}$ que teve início a luta pelo reconhecimento dos direitos sociais, inspirados no movimento socialista, que tinha como principal objetivo a proteção dos direitos dos trabalhadores. Estes direitos, entretanto, em razão da resistência política da época, só foram expressamente previstos no final do século $\mathrm{XX}$, quando os detentores do capital viram-se forçados a entrar em composição com os trabalhadores, sob pena de perderem a força de trabalho e os lucros.

${ }^{10}$ LAFER, Celso. Declaração Universal dos Direitos Humanos (1948). In MAGNOLI, Demétrio (org.). História da Paz. São Paulo: Contexto, 2008. pp. 297-298.

11 “A chamada Revolução Americana foi essencialmente, no mesmo espírito da Glorious Revolution inglesa, uma restauração das antigas franquias e dos tradicionais direitos de cidadania, diante dos abusos e usurpações do poder monárquico. Na Revolução Francesa, bem ao contrário, todo o ímpeto do movimento político tendeu ao futuro e representou uma tentativa de mudança radical das condições de vida em sociedade. O que se quis foi apagar completamente o passado e recomeçar a História do marco zero- reinício muito bem simbolizado pela mudança de calendário. Ademais, enquanto os norte-americanos mostraram-se mais interessados em firmar sua independência em relação à coroa britânica do que em estimular igual movimento em outras colônias européias, os franceses consideraram-se investidos de uma missão universal de libertação dos povos. E, efetivamente, o espírito da Revolução Francesa difundiu-se, em pouco tempo, a partir da Europa, a regiões tão distantes quanto o subcontinente indiano, a Ásia Menor e a América Latina" (COMPARATO, Fábio Konder. A Afirmação Histórica dos Direitos Humanos. $4^{\mathrm{a}}$ ed. São Paulo: Saraiva, 2005. p. 51).

${ }^{12}$ Cumpre lembrar que a Constituição mexicana (1917) foi a primeira a prever os direitos dos trabalhadores como direitos fundamentais, seguida pela Constituição Alemã de Weimar (1919). Nesse sentido: “O que importa, na verdade, é o fato de que a Constituição mexicana, em reação ao sistema capitalista, foi a primeira a estabelecer a desmercantilização do trabalho, ou seja, a proibição de equipará-lo a uma mercadoria qualquer, sujeita à lei da oferta e da procura no mercado. Ela firmou o princípio da igualdade substancial de posição jurídica entre trabalhadores e empresários na relação contratual de trabalho, criou a responsabilidade dos empregadores por acidentes do trabalho e lançou, de modo geral, as bases para a construção do moderno Estado Social de Direito. Deslegitimou, com isso, as práticas de exploração mercantil do trabalho e, portanto da pessoa humana, cuja justificativa se procurava fazer, abusivamente, sob a invocação da liberdade de contratar" (COMPARATO, Fábio Konder. A Afirmação Histórica dos Direitos Humanos. $4^{a}$ ed. São Paulo: Saraiva, 2005. p. 177). 
Como decorrência desses acontecimentos históricos, as declarações de direito do século XX mesclaram duas tendências fundamentais: o universalismo, implícito na Declaração dos Direitos do Homem e do Cidadão, e o socialismo (aqui entendido como movimento voltado à proteção dos direitos sociais e à resistência ao individualismo). ${ }^{13}$

Dessa maneira, os movimentos sociais e os documentos que deles decorreram procuraram combater o individualismo marcante do século XVIII e garantir os direitos da coletividade como um todo, através da limitação dos direitos individuais, antes tidos como absolutos, e da maior intervenção do Estado na vida privada.

A Segunda Guerra Mundial, entretanto, alterou completamente o paradigma das declarações de direitos até então existentes. As atrocidades cometidas durante a guerra e a total desconsideração da dignidade humana demonstraram que a previsão dos direitos fundamentais, não apenas nas Constituições de cada país, mas principalmente pela ordem internacional, era indispensável para a própria existência dos Estados.

Se a Primeira Guerra Mundial demonstrou que os seres humanos eram frágeis e extremamente vulneráveis aos avanços tecnológicos da indústria armamentista, a Segunda Guerra Mundial deixou claro que a tecnologia aliada à banalidade do mal poderia causar a destruição em massa da humanidade.

Com a finalidade preservar a humanidade, foram editados dois importantes documentos internacionais, a saber: a Declaração Universal dos Direitos Humanos (aprovada pela Assembléia Geral das Nações Unidas em 10 de dezembro de 1948) e a Convenção Internacional sobre a Prevenção e Repressão do Crime de Genocídio (1948). A partir destes documentos, teve início uma nova fase na sistemática de proteção dos direitos humanos: a da internacionalização dos direitos humanos.

\footnotetext{
${ }^{13}$ Nesse sentido, conferir: SILVA, José Afonso da. Curso de Direito Constitucional Positivo. $37^{\mathrm{a}}$ ed. São Paulo: Malheiros, 2014, p. 164: “(...) As declarações de direito do século XX procuraram consubstanciar duas tendências fundamentais: universalismo, implícito já na Declaração francesa de 1789, e socialismo (tomada essa expressão em sentido amplo, ligado a social, e não técnico-científico), com a extensão do número dos direitos reconhecidos, o surgimento dos direitos sociais, uma inclinação ao condicionamento dos direitos de propriedade e aos demais direitos individuais, propensão que refletiu no Direito Constitucional contemporâneo".
} 
Antes de se adentrar na análise destes documentos internacionais, é importante mencionar que eles foram antecedidos pela Carta da Organização das Nações Unidas, assinada em São Francisco aos 26 de junho de 1945, cujo preâmbulo assim dispôs:

\begin{abstract}
NÓS, OS POVOS DAS NAÇÕES UNIDAS, RESOLVIDOS a preservar as gerações vindouras do flagelo da guerra, que por duas vezes, no espaço da nossa vida, trouxe sofrimentos indizíveis à humanidade, e a reafirmar a fé nos direitos fundamentais do homem, na dignidade e no valor do ser humano, na igualdade de direito dos homens e das mulheres, assim como das nações grandes e pequenas, e a estabelecer condições sob as quais a justiça e o respeito às obrigações decorrentes de tratados e de outras fontes do direito internacional possam ser mantidos, e a promover o progresso social e melhores condições de vida dentro de uma liberdade ampla. E PARA TAIS FINS, praticar a tolerância e viver em paz, uns com os outros, como bons vizinhos, e unir as nossas forças para manter a paz e a segurança internacionais, e a garantir, pela aceitação de princípios e a instituição dos métodos, que a força armada não será usada a não ser no interesse comum, a empregar um mecanismo internacional para promover o progresso econômico e social de todos os povos.

RESOLVEMOS CONJUGAR NOSSOS ESFORÇOS PARA A CONSECUÇÃO DESSES OBJETIVOS. Em vista disso, nossos respectivos Governos, por intermédio de representantes reunidos na cidade de São Francisco, depois de exibirem seus plenos poderes, que foram achados em boa e devida forma, concordaram com a presente Carta das Nações Unidas e estabelecem, por meio dela, uma organização internacional que será conhecida pelo nome de Nações Unidas.
\end{abstract}

Conforme se pode perceber pela leitura de seu preâmbulo, a Carta das Nações Unidas encontrou inspiração nos horrores das duas Grandes Guerras e teve como objetivo a criação de uma organização internacional voltada para a proteção do ser humano e não dos Estados soberanos,

De acordo com os ensinamentos de Celso Lafer,

A Carta da ONU como um texto jurídico que aspira a uma "constitucionalização" das relações internacionais, e cuja fonte material foi buscar "preservar as gerações vindouras do flagelo da guerra"- é muito mais abrangente, em matéria de direitos humanos, do que foi o Pacto da Sociedade das Nações, que é o seu antecedente jurídico. Com efeito, é com a Carta da ONU quer os direitos humanos passam a ser, para recorrer a uma formulação de J.A. Lindgren Alves, um tema global inserido na agenda internacional. Adquirem uma hierarquia axiológica que comporta um paralelismo com o que vinha ocorrendo no plano interno, na experiência do direito constitucional.

(...)

Em síntese: a Carta da ONU tem uma amplitude que o Pacto da Sociedade das Nações não tinha. Representou um "direito novo" axiologicamente sensível a uma visão kantiana, seja na sua abertura a uma razão abrangente da humanidade, seja porque desenhou a possibilidade de efetivar um jus cosmopoliticum, um direito cosmopolita. Este traduz a conjetura de uma contenção de 
discricionariedade da "razão de estado" ex parte principis das soberanias impeditivas da tutela jurídica internacional da pessoa humana. ${ }^{14}$ (grifos do autor)

Alguns anos depois da assinatura da Carta das Nações, a Organização das Nações Unidas, por ela criada, proclamou a Declaração dos Direitos Humanos, que "logrou um surpreendente consenso inter-estatal sobre a relevância dos direitos humanos, considerando a diversidade dos regimes políticos, dos sistemas filosóficos e religiosos e das tradições culturais dos Estados-membros da ONU (...)". ${ }^{15}$

Dessa maneira, pode-se afirmar que esta Declaração de Direitos Internacional teve como mérito consagrar o caráter universal dos direitos humanos, através do reconhecimento de que todos os seres humanos, independentemente de suas características pessoais ou crenças, são iguais em dignidade. ${ }^{16}$

Neste contexto, Norberto Bobbio lembra que, com a promulgação da Declaração Universal de $1948^{17}$, os direitos humanos passaram da qualidade de particulares e positivos, provenientes das declarações de direitos do século XVIII, à qualidade de universais e positivos. Nesse sentido:

\footnotetext{
${ }^{14}$ LAFER, Celso. A Internacionalização dos Direitos Humanos: O Desafio do Direito a Ter Direitos. Revista do Tribunal Regional Federal da $3^{a}$ Região, vol. 75, pp. 44-45, jan. e fev./2006.

${ }^{15}$ LAFER, Celso. Declaração Universal dos Direitos Humanos (1948). In MAGNOLI, Demétrio (org.). História da Paz. São Paulo: Contexto, 2008. p. 301.

${ }^{16}$ De acordo com a lição de Fábio Konder Comparato, "Inegavelmente, a Declaração Universal de 1948 representa a culminância de um processo ético que, iniciado com a Declaração de Independência dos Estados Unidos e a Declaração dos Direitos do Homem e do Cidadão, da Revolução Francesa, levou ao reconhecimento da igualdade essencial de todo ser humano em sua dignidade de pessoa, isto é, como fonte de todos os valores, independentemente das diferenças de raça, cor, sexo, língua, religião, opinião, origem nacional ou social, riqueza, nascimento, ou qualquer outra condição, como se diz em seu artigo II. E esse reconhecimento universal da igualdade humana só foi possível quando, ao término da mais desumanizadora guerra de toda a História, percebeu-se que a superioridade de uma raça, de uma classe social, de uma cultura ou de uma religião, sobre todas as demais, põe em risco a própria sobrevivência da humanidade" (COMPARATO, Fábio Konder. A Afirmação Histórica dos Direitos Humanos. $4^{\mathrm{a}}$ ed. São Paulo: Saraiva, 2005. p. 225).

${ }^{17}$ Como bem lembrado por Celso Lafer, “A Declaração de 1948 não é uma soma de Declarações nacionais nem uma ampliação em escala mundial dessas Declarações, por mais completas e aprofundadas que possam ser. Ela inova ao formular, no plano universal, direitos humanos que não estão ao alcance de uma jurisdição nacional, pois leva em conta a tutela internacional dos direitos que permitem o arendtiano direito a ter direitos. Nessa linha, cabe destacar o art. $6^{\circ}$ da Declaração: "Toda a pessoa tem o direito de ser em todos os lugares reconhecida como pessoa perante a lei". Esse artigo afirma o indispensável laço do ser humano com a ordem jurídica, que é o núcleo duro de todo processo de positivação dos direitos humanos. $\mathrm{O}$ art. $6^{\circ}$ dá combate ao aniquilamento jurídico da pessoa humana, sobre o qual Hannah Arendt refletiu ao discutir a experiência dos displaced people" (LAFER, Celso. Direitos Humanos em Hannah Arendt: Considerações sobre as Fontes Materiais da Declaração Universal de 1948. São Paulo, Justitia, n. 65, p. 113, jan./jun. 2008).
} 
Com a Declaração de 1948 tem início uma terceira e última fase, na qual a afirmação dos direitos é, ao mesmo tempo, universal e positiva: universal no sentido de que os destinatários dos princípios nela contidos não são mais os cidadãos deste ou daquele Estado, mas todos os homens; positiva no sentido de que põe em movimento um processo em cujo final os direitos do homem deverão ser não mais apenas proclamados ou apenas idealmente reconhecidos, porém efetivamente protegidos até mesmo contra o próprio Estado que os tenha violado. No final deste processo, os direitos do cidadão terão se transformado, realmente, positivamente, em direitos do homem. Ou, pelo menos, serão os direitos do cidadão daquela cidade que não tem fronteiras, porque compreende toda a humanidade; ou, em outras palavras, serão os direitos do homem enquanto direitos do cidadão do mundo. Somos tentados a descrever o processo de desenvolvimento que culmina da Declaração Universal também de um outro modo, servindo-nos das categorias tradicionais do direito natural e do direito positivo: os direitos do homem nascem como direitos naturais universais, desenvolvem-se como direitos positivos particulares, para finalmente encontrarem sua plena realização como direitos positivos universais. A Declaração Universal contém em germe a síntese de um movimento dialético, que começa pela universalidade abstrata dos direitos naturais, transfigura-se na particularidade concreta dos direitos positivos, e termina na universalidade não mais abstrata, mas também concreta, dos direitos positivos universais. ${ }^{18}$ (grifos do autor)

Cumpre lembrar, entretanto, que a universalidade dos direitos humanos, afirmada pela Declaração dos Direitos Humanos, foi contestada por países do Oriente, em especial após a Guerra Fria, sob o argumento de que estes direitos espelhavam os valores individualistas do Ocidente. Esta divergência de pensamento ficou clara nos debates que antecederam a Conferência de Viena, conforme pontuado por Benoni Belli:

O consenso era improvável em função das dificuldades oriundas desse cenário internacional pós-Guerra Fria, com o surgimento de conflitos étnicos, a revalorização das particularidades culturais e religiosas, os episódios de ódio racial e violência contra imigrantes africanos na Europa e em outras partes do mundo desenvolvido, os massacres na África, a disseminação da xenofobia, a exacerbação de uma globalização econômica que não oferecia garantia de bemestar para vastas camadas da população mundial e o reforço do etnocentrismo ocidental.

(...)

A ideia dos chamados "valores asiáticos" havia se manifestado com força no processo preparatório da Conferência de Viena. Países como Cingapura e Malásia foram particularmente ativos na defesa da especificidade asiática e no caráter ocidental e limitado da Declaração Universal dos Direitos Humanos. Em geral, o que se notava nos discursos desses países e de outros, como a China, Indonésia e Mianmar, era a visão segundo a qual a concepção ocidental de direitos humanos privilegiava o individualismo, em detrimento da coletividade ou das obrigações dos membros da sociedade perante a comunidade. Além disso, não eram incomuns alegações de que os direitos individuais faziam pouco sentido em meio à pobreza extrema e à falta de desenvolvimento. Nesse sentido, o sacrifício de direitos civis e políticos no estilo ocidental seria necessário para a estabilidade e para a garantia da satisfação de necessidades mais básicas. A essa voz asiática contra a ideia de universalidade dos direitos humanos, somou-se a contestação islâmica, que já se havia manifestado em 1948 por meio da

\footnotetext{
${ }^{18}$ BOBBIO, Norberto. A Era dos Direitos. Rio de Janeiro: Elsevier, 2004. pp. 29-30.
} 
abstenção da Arábia Saudita na consideração da Declaração Universal dos Direitos Humanos pela Assembleia Geral. ${ }^{19}$

A Conferência de Viena (1993), entretanto, conseguiu sedimentar qualquer dúvida que ainda existisse a respeito da universalidade dos direitos humanos (ao menos na teoria), conforme se verifica do disposto no parágrafo $5^{\circ}$ da Declaração e Programa de Ação de Viena:

Todos os direitos humanos são universais, indivisíveis, interdependentes e interrelacionados. A comunidade internacional deve tratar os direitos humanos globalmente de forma justa e equitativa, em pé de igualdade e com a mesma ênfase. As particularidades nacionais e regionais devem ser levadas em consideração, assim como os diversos contextos históricos, culturais e religiosos, mas é dever do Estado promover e proteger todos os direitos humanos e liberdades fundamentais, independentemente de seus sistemas políticos, econômicos e sociais.

Ressalte-se, porém, que, conforme se percebe pela leitura do dispositivo acima transcrito, o reconhecimento da universalidade dos direitos humanos não implica na desconsideração das particularidades históricas, culturais e religiosas de cada indivíduo. Muito pelo contrário, a comunidade internacional busca garantir o respeito a todos os seres humanos, em suas igualdades e diferenças. Afinal, foi justamente a desconsideração do outro e a falta de respeito às diferenças que justificaram o genocídio de milhares de judeus durante a Segunda Guerra Mundial e impulsionaram a proteção internacional do ser humano.

Dessa maneira, a Declaração de Viena ${ }^{20}$ representou um grande avanço na luta pelos direitos humanos, ainda que na prática a dicotomia entre a universalidade e o relativismo cultural ainda exista.

${ }^{19}$ BELLI, Benoni. A politização dos Direitos Humanos. O Conselho de Direitos Humanos das Nações Unidas e as Resoluções sobre países. São Paulo: Perspectiva, 2009. pp. 97-99.

20 "A Conferência de Viena, neste aspecto, conseguiu aprovar texto que afirma a universalidade dos direitos humanos, sem deixar de reconhecer a importância das particularidades culturais. Buscou transcender o debate simplificador e o monolitismo que se nutre de estereótipos. É claro que, como texto de compromisso, é possível fazer distintas leituras e o estilo é um tanto 'barroco', com circunlóquios que tendem a confundir o leitor desavisado. Não obstante, o avanço foi real e a linguagem, em que pese a 'ambigüidade construtiva' própria do discurso político multilateral, estabeleceu determinados parâmetros que favorecem a universalidade de todos os direitos humanos" (BELLI, Benoni. A politização dos Direitos Humanos. O Conselho de Direitos Humanos das Nações Unidas e as Resoluções sobre países. São Paulo: Perspectiva, 2009. p. 101). 
Ademais de reafirmar o caráter universal dos direitos humanos, a Declaração de Viena previu a indivisibilidade destes direitos, na mesma linha da Declaração Universal dos Direitos Humanos, espancando qualquer dúvida ou resistência política que ainda pudesse existir quanto ao reconhecimento dos direitos sociais. Dessa maneira, essas duas Declarações partiram do princípio de que a garantia dos direitos humanos só é eficaz quando são garantidos os direitos civis, políticos e sociais, de forma una e indissociável.

Nesse sentido:

\begin{abstract}
A Declaração de 1948 introduz a concepção contemporânea de direitos humanos, marcada pela universalidade e a indivisibilidade desses direitos. Universalidade porque a condição de pessoa é o requisito único e exclusivo para a titularidade de direitos, sendo a dignidade humana o fundamento dos direitos humanos. Indivisibilidade porque, ineditamente, o catálogo dos direitos civis e políticos é conjugado ao catálogo dos direitos econômicos, sociais e culturais. Ao consagrar direitos civis e políticos e direitos econômicos, sociais e culturais, a Declaração ineditamente combina o discurso liberal e o discurso social da cidadania, conjugando o valor da liberdade ao valor da igualdade. ${ }^{21}$
\end{abstract}

Por outro lado, a Convenção para a Prevenção e a Repressão do Crime de Genocídio (1948), acima mencionada como um dos documentos internacionais que marcaram o início da preocupação da comunidade internacional com a preservação da humanidade, diversamente dos documentos que a antecederam, trata do genocídio como crime autônomo, não vinculado necessariamente à guerra.

Esta Convenção se valeu do conceito de genocídio utilizado pela Assembleia Geral das Nações Unidas, em 1946, quando da aprovação da Resolução n. 96 (I), que assim dispõe:

O genocídio é a denegação do direito à existência de grupos humanos inteiros, assim como o homicídio é a denegação do direito à vida de indivíduos humanos. Essa denegação do direito à existência choca a consciência da humanidade, provoca grandes perdas humanas sob a forma de contribuições culturais ou de outra espécie, feitas por estes grupos humanos, contrariando a lei moral, bem como o espírito e os objetivos das Nações Unidas.

Vários casos de tais crimes de genocídio têm ocorrido, quando grupos raciais, religiosos, políticos ou de outra natureza são destruídos, no todo ou em parte. A punição do crime de genocídio é uma questão de interesse internacional.

A Assembléia Geral, em conseqüência,

Afirma que o genocídio é um crime segundo o direito internacional, o qual é condenado pelo mundo civilizado, e cujos autores principais ou cúmplicessejam eles indivíduos privados, funcionários públicos ou agentes do Estado,

${ }^{21}$ PIOVESAN, Flávia. Temas de Direitos Humanos. $4^{\text {a }}$ ed. São Paulo: Saraiva, 2010. p. 40. 
quando o crime é cometido por razões religiosas, raciais, políticas ou de outra natureza- devem ser punidos;

Convida os Estados-Membros a promulgar as leis competentes para a preservação e punição de tais crimes;

Recomenda seja organizada a cooperação entre os Estados com o fito de facilitar a rápida prevenção e punição do crime de genocídio e, com esse objetivo,

Requer que o Conselho Econômico e Social envide os necessários estudos, a fim de elaborar um projeto de convenção sobre o crime de genocídio, a ser submetido à Assembléia Geral, em sua próxima sessão ordinária. (grifos no original)

Percebe-se, assim, que a Declaração Universal dos Direitos Humanos, ao reconhecer o caráter universal e indivisível dos direitos humanos, aliada à Convenção para a Prevenção e a Repressão do Crime de Genocídio, que prevê o genocídio como crime contra a humanidade, traça as linhas básicas da concepção contemporânea dos direitos humanos, que se funda: (1) na revisão da noção tradicional de soberania e (2) no reconhecimento de que o ser humano merece proteção internacional (até mesmo contra si próprio).

Dessa maneira, pode-se afirmar que, após anos de lutas e conflitos, a comunidade jurídica chegou à conclusão de que a proteção dos direitos humanos não deveria ficar restrita ao domínio do Estado. A proteção dos direitos fundamentais passou a ser vista como matéria de competência internacional, sendo que as decisões advindas de sua violação produzem efeitos nos ordenamentos jurídicos de todos os países.

Tanto isso é verdade que as constituições internas, promulgadas após o início do processo de internacionalização dos direitos humanos, foram direta e inegavelmente influenciadas pelas normas previstas na Declaração Universal dos Direitos Humanos, nos Pactos que a regulamentaram e nos demais tratados internacionais de direitos humanos, de alcance geral ou específico.

No caso brasileiro, especificamente, estes documentos internacionais tiveram influência direta no processo de democratização do país (ou vice-versa), como bem lembrado por Flávia Piovesan:

No caso brasileiro, o processo de incorporação do Direito Internacional dos Direitos Humanos e de seus importantes instrumentos é conseqüência do processo de democratização, iniciado em 1985. O processo de democratização possibilitou a reinserção do Brasil na arena internacional dos direitos humanos- 
embora relevantes medidas ainda necessitem ser adotadas pelo Estado brasileiro para o completo alinhamento do país à causa da plena vigência dos direitos humanos.

Não obstante ações serem essenciais para o completo alinhamento do país à causa dos direitos humanos, há que se reiterar que na experiência brasileira fazse clara a relação entre o processo de democratização e a reinserção do Estado brasileiro no cenário internacional de proteção dos direitos humanos. Percebe-se a dinâmica e a dialética da relação entre democracia e direitos humanos, tendo em vista que, se o processo de democratização permitiu a ratificação de relevantes tratados internacionais de direitos humanos, por sua vez a incorporação desses tratados permitiu o fortalecimento do processo democrático, mediante a ampliação e o reforço do universo de direitos por ele assegurado. Se a busca democrática não se atém apenas ao modo pelo qual o poder político é exercido, mas envolve também a forma pela qual direitos fundamentais são implementados, é manifesta a contribuição da sistemática internacional de proteção dos direitos humanos para o aperfeiçoamento do sistema de tutela desses direitos no Brasil. Nesse prisma, o aparato internacional permite intensificar as respostas jurídicas em face dos casos de violação dos direitos humanos e, consequentemente, ao reforçar a sistemática de proteção de direitos, o aparato internacional permite o aperfeiçoamento do próprio regime democrático. Atenta-se, assim, para modo pelo qual os direitos humanos internacionais inovam a ordem jurídica brasileira, complementando e integrando o elenco dos direitos nacionalmente consagrados e nele introduzindo novos direitos, até então não previstos pelo ordenamento jurídico interno. ${ }^{22}$

Feitas estas considerações, resta claro que os direitos humanos encontram guarida em nosso sistema jurídico interno e no sistema jurídico internacional, de forma complementar, não havendo dúvidas de que os indivíduos estão plenamente amparados no plano normativo.

Resta saber, entretanto, se este aparato normativo é eficaz e suficiente para proteger os indivíduos das possíveis violações a seus direitos. No campo específico do direito internacional, Celso Lafer afirma que a aplicação efetiva das normas de direitos humanos encontra barreiras na vontade política de cada país, na intolerância e nas tensões internacionais. Nesse sentido:

Qual é a efetividade da ambição normativa proveniente do direito internacional dos direitos humanos? A relação entre o dever ser das normas e o ser da realidade na qual incidem é sempre problemática e mais ainda no sistema internacional, no qual o Poder, que torna o direito realizável, está distribuído individual e desigualmente entre os seus protagonistas. Daí o desafio da efetividade que, em matéria de direitos humanos, provém das tradicionais suscetibilidades das soberanias diante da intrusiva ação que representam no campo dos valores; das conhecidas seletividades da "razão de Estado" na condução das políticas externas; da multiplicação das difusas tensões internacionais de hegemonia e de equilíbrio; da dinâmica interação contemporânea entre as forças centrípetas da globalização e das forças centrífugas que alimentam a sublevação dos particularismos; do ímpeto

${ }^{22}$ PIOVESAN, Flávia. Temas de Direitos Humanos. $4^{\mathrm{a}}$ ed. São Paulo: Saraiva, 2010. pp. 73-74. 
intolerante dos fundamentalismos e dos ódios públicos; dos unilateralismos políticos degeneradores do multilateralismo e do valor do pluralismo na sociedade internacional (...). ${ }^{23}$ (grifos do autor)

Norberto Bobbio, por sua vez, chama a atenção para as conjecturas internas e externas e para as limitações econômicas enfrentadas pelos países na concretização dos direitos humanos, em especial dos direitos sociais:

(...) Nem tudo que é desejável e merecedor de ser perseguido é realizável. Para a realização dos direitos do homem são frequentemente necessárias condições objetivas que não dependem da boa vontade dos que os proclamam, nem das boas disposições dos que possuem os meios para protegê-los. Mesmo o mais liberal dos Estados se encontra na necessidade de suspender alguns direitos de liberdade em tempos de guerra; do mesmo modo o mais socialista dos Estados não terá condições de garantir o direito a uma retribuição justa em épocas de carestia. Sabe-se que o tremendo problema diante do qual estão hoje os países em desenvolvimento é o de se encontrarem em condições econômicas que, apesar dos programas ideais, não permitem desenvolver a proteção da maioria dos direitos sociais. O direito ao trabalho nasceu com a Revolução Industrial e é estreitamente ligado à sua consecução. Quanto a este direito, não basta fundamentá-lo ou proclamá-lo. Nem tampouco basta protegê-lo. O problema de sua realização não é nem filosófico nem moral. Mas tampouco é um problema jurídico. É um problema cuja solução depende de um certo desenvolvimento da sociedade e, como tal, desafia até mesmo a Constituição mais evoluída e põe em crise até mesmo o mais perfeito mecanismo de garantia jurídica. ${ }^{24}$

Percebe-se pela leitura dos ensinamentos acima que a eficácia de suas normas ainda encontra desafios de ordem política e econômica, apesar de o sistema de proteção dos direitos humanos, tanto no plano interno como no internacional, ser satisfatório e voltado à proteção dos indivíduos não só contra os abusos do Estado, como também contra as violações perpetradas por seus semelhantes. ${ }^{25}$

Estes desafios e entraves, entretanto, não são e nem deveriam ser capazes de apagar a evolução dos direitos humanos nos últimos séculos ou de diminuir o otimismo da

${ }^{23}$ LAFER, Celso. A Declaração Universal dos Direitos Humanos - Sua Relevância para a Afirmação da Tolerância e do Pluralismo. In MARCÍLIO, Maria Luiza et al (org.). A Declaração Universal dos Direitos Humanos. Sessenta Anos. Sonhos e Realidades. São Paulo: Editora da Universidade de São Paulo, 2008. p. 41.

${ }^{24}$ BOBBIO, Norberto. A Era dos Direitos. Rio de Janeiro: Elsevier, 2004. pp. 43-44.

${ }^{25}$ Conforme lembrado por Benoni Belli, a própria divergência a respeito do caráter universal dos direitos humanos acaba acarretando um enfraquecimento destes direitos e a politização do sistema de proteção dos direitos humanos da ONU: “(...) Formou-se, assim, pelo efeito de reforço mútuo que as polarizações simplistas costumam acarretar, círculo vicioso que contribui para agravar a politização do sistema dos direitos humanos da ONU. O etnocentrismo hedonista de determinados círculos ocidentais e o relativismo cultural de seus adversários internos e externos serviram, ambos à sua maneira, para emprestar caráter de profecia que se autocumpre às teorias pós-modernas sobre o fim do potencial utópico dos direitos humanos como grande campo de realização da humanidade em sua trajetória histórica" (BELLI, Benoni. A politização dos Direitos Humanos. O Conselho de Direitos Humanos das Nações Unidas e as Resoluções sobre países. São Paulo: Perspectiva, 2009. p. 95). 
humanidade com relação a estas conquistas. Afinal, a proteção dos direitos humanos é resultado de um processo constante e progressivo de lutas e vitórias.

\title{
1.2. Conceito
}

Conceituar direitos fundamentais não é tarefa fácil, já que seu conteúdo e sua abrangência são diretamente influenciados pelas constantes alterações sociais e políticas, como lembrado por José Afonso da Silva: ${ }^{26}$

\begin{abstract}
A ampliação e a transformação dos direitos fundamentais do homem no evolver histórico dificulta definir-lhes um conceito sintético e preciso. Aumenta essa dificuldade a circunstância de se empregarem várias expressões para designá-los, tais como: direitos naturais, direitos humanos, direitos do homem, direitos individuais, direitos públicos subjetivos, liberdades fundamentais, liberdades públicas e direitos fundamentais do homem. (grifos do autor)
\end{abstract}

A transcrição acima deixa claro que a definição dos direitos fundamentais esbarra não somente em óbices materiais, como também em empecilhos semânticos. Tanto isso é verdade que a doutrina e a legislação, nacional e internacional, ao se referirem aos direitos fundamentais, se utilizam de terminologias diversas, a saber: "direitos humanos", "direitos naturais", “direitos morais", “liberdades públicas" e "direitos individuais", exemplificativamente.

Apesar de as expressões aqui mencionadas serem tratadas, por vezes, como sinônimas pela doutrina e utilizadas de forma aleatória pelo nosso ordenamento jurídico, ${ }^{27}$ existem diferenças substanciais entre algumas delas, que merecem consideração.

\footnotetext{
${ }^{26}$ SILVA, José Afonso da. Curso de Direito Constitucional Positivo. 37 ed. São Paulo: Malheiros, 2014. p. 177.

27 "Alguns desses termos são utilizados na própria Constituição Federal, que não foi consequente na terminologia. Isso é lamentável, pois aqui temos uma 'questão terminológica essencial' em dois sentidos. Primeiro porque os vários termos adquiriram significados diferentes na história constitucional mundial, segundo, porque o emprego de certo termo pela Constituição Federal pode oferecer argumentos sistemáticos a favor ou contra a tutela de certos direitos, por exemplo, sugerindo a exclusão dos direitos sociais quando há referência a 'direitos individuais' ou a 'liberdades fundamentais"' (DIMOULIS, Dimitri; MARTINS, Leonardo. In LEITE, George Salomão; SARLET, Ingo Wolfgang (Org.). Direitos Fundamentais e Estado Constitucional. Estudos em Homenagem a J.J. Gomes Canotilho. Coimbra: Coimbra Editora, 2009. pp. 118119 (grifos dos autores).
} 
Os direitos naturais, que tiveram como inspiração a teoria jusnaturalista de John Locke, são a fase inicial do reconhecimento dos direitos fundamentais, encontrando fundamento em concepções religiosas e éticas do Direito. Estes direitos são inerentes à própria natureza do homem e anteriores à existência do Estado.

Em razão da historicidade dos direitos humanos, os direitos naturais, apesar de ainda fazerem parte do conteúdo dos direitos humanos, perderam espaço para o direito positivado. $^{28}$

Os direitos individuais, por sua vez, são espécies de direitos fundamentais, referindo-se exclusivamente aos direitos de primeira geração (direitos civis e políticos). Em outras palavras, os direitos individuais integram os direitos fundamentais, mas neles não se esgotam.

Da mesma forma, a expressão "liberdades públicas" tão utilizada pela doutrina francesa não pode ser vista como sinônimo de direitos fundamentais, por não abarcar os direitos sociais, mostrando-se restritiva e insuficiente.

Por fim e não menos importante, deve ser analisada a equiparação entre os direitos humanos e os direitos fundamentais. ${ }^{29}$

\footnotetext{
${ }^{28}$ Nos dizeres de Norberto Bobbio, “(...) a idéia de que o homem enquanto tal tem direitos, por natureza, que ninguém (nem mesmo o Estado) lhe pode subtrair, e que ele mesmo não pode alienar (mesmo que, em caso de necessidade, ele os aliene, a transferência não é válida), essa idéia foi elaborada pelo jusnaturalismo moderno. Seu pai John Locke. (...) A liberdade e a igualdade dos homens não são um dado de fato, mas um ideal a perseguir; não são uma existência, mas um valor; não são um ser, mas um dever ser. Enquanto teorias filosóficas, as primeiras afirmações dos direitos do homem são pura e simplesmente a expressão de um pensamento individual: são universais em relação ao conteúdo, na medida em que se dirigem a um homem racional fora do espaço e do tempo, mas são extremamente limitadas em relação à sua eficácia, na medida em que são (na melhor das hipóteses) propostas para um futuro legislador" (BOBBIO, Norberto. A Era dos Direitos. Rio de Janeiro: Elsevier, 2004. pp. 28-29).

29 "Há quem separe direitos humanos de direitos fundamentais. Mas não é de ser aceito esse entendimento de que os direitos humanos e os direitos fundamentais constituem dois institutos jurídicos distintos. Essa separação retira humanidade do fundamental e fundamentalidade do humano, ao passo que na realidade do mundo jurídico o que se verifica é que, contrariando essa dissociação doutrinária, os direitos humanos se associam, ora como direitos mais fundamentais, ora como direitos mais operacionais, colocando em ação um só e mesmo instituto para atender a uma só e mesma finalidade: realizar o ser humano em todos os indivíduos humanos, nas condições de dignidade próprias de cada época da história da sua civilização. Em verdade, não só realizar, mas também garantir a humanidade assim realizada" (BARROS, Sérgio Resende de. Direitos Humanos e Direito de Família. Palestra proferida em 29/08/2003, na XII Jornada de Direito de Família, realizada no Auditório da Assembleia Legislativa do Estado do Rio Grande do Sul. Disponível em <www.srbarros.com.br>. Acesso em 09/01/2013).
} 
Apesar de grande parte dos estudiosos considerarem as expressões "direitos humanos" e "direitos fundamentais" como sinônimas ${ }^{30}$, existem juristas que defendem que a expressão "direitos fundamentais" se aplica somente àqueles direitos positivados no ordenamento jurídico, ao passo que a expressão "direitos humanos" é reservada aos direitos presentes fora do plano estatal, de conotação jusnaturalista. ${ }^{31}$ Outros, ainda, sustentam que os direitos humanos são aqueles previstos nos tratados internacionais de direitos humanos, ao passo que os direitos fundamentais são os positivados pelo Direito Constitucional de cada Estado. ${ }^{32}$

Percebe-se, assim, que o elemento de distinção entre os direitos humanos e os direitos fundamentais é a positivação, podendo se referir à sua existência ou à sua forma, a depender da corrente doutrinária adotada.

Com a finalidade de solucionar este impasse, José Afonso da Silva sugere que seja utilizada a expressão "direitos fundamentais do homem", ${ }^{33}$ nos seguintes termos:

\begin{abstract}
Direitos fundamentais do homem constituem a expressão mais adequada a este estudo, porque, além de referir-se a princípios que resumem a concepção do mundo e informam a ideologia política de cada ordenamento jurídico, é reservada para designar, no nível do direito positivo, aquelas prerrogativas e instituições que ela concretiza em garantias de uma convivência digna, livre e igual de todas as pessoas. No qualificativo fundamentais acha-se a indicação de que se trata de situações jurídicas sem as quais a pessoa humana não se realiza, não convive e, às vezes, nem mesmo sobrevive; fundamentais do homem no sentido de que todos, por igual, devem ser, não apenas formalmente reconhecidos, mas concreta e materialmente efetivados. Do
\end{abstract}

\footnotetext{
${ }^{30}$ Nesse sentido: "Por direitos humanos entendemos um conjunto de faculdades e instituições que, em determinado momento histórico, concretiza as exigências da dignidade, da liberdade e da dignidade humana, as quais devem ser reconhecidas positivamente pelos ordenamentos jurídicos em nível nacional e internacional. São concebidos de forma a incluir aquelas reivindicações morais e políticas que, no consenso contemporâneo, todo ser humano tem o dever de ter, perante sua sociedade ou governo, reconhecidas como direito". (MALUF, Adriana Caldas do Rego Freitas Dabus. Direito das famílias. Amor e bioética. Rio de Janeiro: Elsevier, 2012. p. 60). Percebe-se, assim, que a autora entende que os direitos humanos devem ser reconhecidos pelo ordenamento jurídico nacional ou internacional, em clara demonstração de que a positivação dos direitos não se restringe à expressão "direitos fundamentais".

${ }^{31}$ Conferir TAVARES, André Ramos. Princípio da Dignidade da Pessoa Humana. In Luiz Alberto David Araújo; SEGALlA, José Roberto Martins (coords.). 15 anos da Constituição Federal em busca da efetividade. Bauru: EDITE, 2003, p. 13: "Os direitos fundamentais seriam aqueles direitos positivados no ordenamento jurídico de um determinado Estado, enquanto os direitos humanos seriam aqueles presentes fora do plano estatal (dele independentes) e, assim, de conotação essencialmente jusnaturalista. Pode-se dizer que os direitos humanos, ao contrário dos direitos fundamentais, inferem que o homem, por ser homem, já possui, de per si, direitos inerentes à sua natureza, independentes de sua positivação".

${ }^{32}$ Sobre o assunto, conferir CARVALHO RAMOS, André. Teoria Geral dos Direitos Humanos na Ordem Internacional. $2^{\mathrm{a}}$ ed. São Paulo: Saraiva, 2012. p. 35.

${ }^{33}$ SILVA, José Afonso da. Curso de Direito Constitucional Positivo. $37^{\mathrm{a}}$ ed. São Paulo: Malheiros, 2014. p. 180.
} 
homem, não como o macho da espécie, mas no sentido de pessoa humana (...).

Não restam dúvidas de que a solução apresentada acima leva em consideração elementos centrais do conceito dos direitos fundamentais, como a sua essencialidade e a sua titularidade. Entretanto, por entender que tanto a expressão "direitos humanos", como a expressão "direitos fundamentais" atendem à finalidade aqui pretendida, remetendo o leitor ao conceito exato do instituto, elas serão utilizadas indistintamente, nos moldes defendidos por André de Carvalho Ramos. ${ }^{34}$

Pelo exposto, pode-se afirmar que os direitos humanos são

Direitos próprios de todos os homens, enquanto homens, à diferença dos demais direitos, que só existem e são reconhecidos, em função de particularidades individuais ou sociais do sujeito. Trata-se, em suma, pela sua própria natureza, de direitos universais e não localizados, ou diferenciais. ${ }^{35}$

\subsection{Classificação}

Os direitos fundamentais podem ser classificados tanto pela sua posição formal, quanto pela sua natureza. A abertura material do rol dos direitos fundamentais encontra respaldo no artigo $5^{\circ}, \S 2^{\circ}$ da Constituição Federal vigente, ${ }^{36}$ que prevê a possibilidade de reconhecimento de direitos desta categoria em outra parte do texto constitucional, ${ }^{37}$ sediados em tratados internacionais, implícitos ou decorrentes do sistema. A sistemática dos tratados internacionais de direitos humanos será mencionada novamente adiante, por questão de estruturação lógica.

\footnotetext{
${ }^{34}$ CARVALHO RAMOS, André. Teoria Geral dos Direitos Humanos na Ordem Internacional. $2^{\mathrm{a}}$ ed. São Paulo: Saraiva, 2012. p. 37.

${ }^{35}$ COMPARATO, Fábio Konder. Fundamentos dos Direitos Humanos. São Paulo: Instituto de Estudos Avançados da Universidade de São Paulo, 1997, p. 19. Texto disponível em <www.iea.usp.br/artigos>. Acesso em 19/03/2012.

36 “Os direitos e garantias expressos nesta Constituição não excluem outros decorrentes do regime e dos princípios por ela adotados, ou dos tratados internacionais em que a República Federativa do Brasil seja parte”.

${ }^{37}$ Discute-se a possibilidade de reconhecimento de direitos fundamentais legais. No Brasil, parece que a posição dominante rejeita essa assertiva, por dois motivos, em especial: a) à legislação ordinária cumpre o papel de concretizar e regulamentar os direitos fundamentais positivados na Constituição, tornando-os diretamente aplicáveis; b) a nossa tradição constitucional aponta para a exclusão da legislação infraconstitucional como fonte de direitos materialmente constitucionais.
} 
A par da classificação dos direitos fundamentais em formais e materiais, a doutrina apresenta diversos outros critérios de sistematização da matéria. Ao presente trabalho mostram-se interessantes os critérios que classificam os direitos fundamentais de acordo com seu conteúdo ou segundo suas gerações.

A classificação com base no primeiro critério acima mencionado (conteúdo) subdivide os direitos fundamentais da seguinte maneira, a saber:

a) direitos fundamentais do homem indivíduo, que são aqueles que reconhecem autonomia aos particulares, garantindo iniciativa e independência aos indivíduos diante dos demais membros da sociedade política e do próprio Estado, por isso são denominados direitos individuais, como é de tradição do Direito Constitucional brasileiro (artigo $5^{\circ}$ ), e ainda por liberdades civis e liberdades-autonomia (liberdade, igualdade, segurança, propriedade); b) direitos fundamentais do homem nacional, que são os que têm por conteúdo e objeto a definição da nacionalidade e suas faculdades; c) direitos fundamentais do homem-cidadão, que são os direitos políticos (art. 14, direito de eleger e ser eleito), chamados também direitos democráticos ou direitos de participação política e, ainda, inadequadamente, liberdades políticas (ou liberdadesparticipação), pois estas constituem apenas aspectos dos direitos políticos; d) direitos fundamentais do homem-social, que constituem os direitos assegurados ao homem em suas relações sociais e culturais (art. $6^{\circ}$ : saúde, educação, seguridade social etc.); e) direitos fundamentais do homemmembro de uma coletividade, que a Constituição adotou com direitos coletivos; f) uma nova classe que se forma é a dos direitos fundamentais do homem-solidário, ou direitos fundamentais do gênero humano (direito à paz, ao desenvolvimento, comunicação, meio ambiente, patrimônio comum da humanidade). (grifos nossos). ${ }^{38}$

Levando em consideração a classificação acima apresentada, nossa atual Constituição Federal dispõe sobre os direitos fundamentais da seguinte forma: 1) direitos individuais (art. $5^{\circ}$ ); 2) direitos à nacionalidade (art. 12); 3) direitos políticos (arts. 14 a 17); 4) direitos sociais (arts. $6^{\circ}$ e 193 e ss.); 5) direitos coletivos (art. $5^{\circ}$ ); 6) direitos solidários (arts. $3^{\circ}$ e 225$)$.

A divisão dos direitos fundamentais em gerações (teoria geracional- Karel Vasak, 1979), por outro lado, apresenta-se da seguinte maneira, a saber: a) os direitos de primeira geração, que abrangem os direitos de resistência ou oposição perante o Estado ${ }^{39}$; b) os

${ }^{38}$ SILVA, José Afonso da. Curso de Direito Constitucional Positivo. $37^{\mathrm{a}}$ ed. São Paulo: Malheiros, 2014. pp.185-186.

${ }^{39}$ Os direitos de $1^{\circ}$ geração decorrem do pensamento filosófico do século XIX, tendo como base a liberdade civil e política. Identificam-se com os direitos individuais, que têm como função primordial a limitação do poder do Estado. Dalmo de Abreu Dallari ilustra, com perfeição, o período histórico que identifica a $1^{\circ}$ Geração dos direitos fundamentais: "No final do século XVIII consagrou-se a liberdade como o valor supremo do indivíduo, afirmando-se que se ela fosse amplamente assegurada, todos os valores estariam 
direitos de segunda geração, que se referem às prestações exigidas do Estado, em prol do bem-estar e da igualdade material ${ }^{40}$ e c) os direitos de terceira geração, que visam à proteção do gênero humano e encontram fundamento na fraternidade. São exemplos destes direitos o direito ao desenvolvimento, o direito à paz, o direito ao meio ambiente, o direito de propriedade sobre o patrimônio comum da humanidade e o direito de comunicação.

Ressalte-se que Paulo Bonavides ${ }^{41}$ admite a existência de uma quarta geração de direitos fundamentais, provenientes da globalização política na esfera da normatividade jurídica. São exemplos destes direitos o direito à democracia, o direito à informação e o direito ao pluralismo.

A utilização da terminologia gerações de direitos fundamentais enfrentou diversas críticas por parte da doutrina. Paulo Bonavides defende que a palavra geração transmite a ideia de sucessão ${ }^{42}$ de uma geração pela outra, sendo que, na verdade, o que ocorre, na prática, é a cumulação dos direitos. Em razão disso, propõe a utilização do termo "dimensão" de direitos fundamentais. ${ }^{43}$

protegidos, inclusive a igualdade. $\mathrm{O}$ que se considerava indispensável era que não houvesse qualquer interferência do Estado, deixando-se todos os indivíduos igualmente livres para cuidarem de seus próprios interesses. Mas a experiência demonstrou com muita eloqüência que tal regime, na realidade, só assegurava a liberdade para os que participavam do poder econômico. Os que dependiam do próprio trabalho para viver foram ficando cada vez mais distanciados dos pouco que detinham o capital, mal ganhando para sobreviver e sem a mínima possibilidade de progredir econômica e socialmente".

${ }^{40} \mathrm{O}$ reconhecimento da liberdade como valor supremo gerou grande desnível social, que se acentuou após a Revolução Industrial. Os trabalhadores chegavam a trabalhar mais de dez horas por dia, ganhando um salário insuficiente para suprir suas necessidades básicas. Foi então que, com base nas ideias de Karl Marx, o proletariado inglês passou a reivindicar seus direitos. Queriam melhores condições de trabalho, exigindo a intervenção estatal em favor dos hipossuficientes. Em consequência, os direitos fundamentais de $2^{\circ}$ geração surgiram através do reconhecimento dos direitos sociais, no século XX, encontrando na igualdade o seu fundamento.

${ }^{41}$ BONAVIDES, Paulo. Curso de Direito Constitucional. $28^{\mathrm{a}}$ ed. São Paulo: Malheiros, 2013. p. 590.

${ }^{42}$ Verificar SILVA, José Afonso da. Curso de Direito Constitucional Positivo. $37^{\mathrm{a}}$ ed. São Paulo: Malheiros, 2014. pp. 186-187: “A Constituição, agora, fundamenta o entendimento de que as categorias de direitos humanos fundamentais, nela previstos, integram-se num todo harmônico, mediante influências recíprocas, até porque os direitos individuais, consubstanciados no seu artigo $5^{\circ}$, estão contaminados de dimensão social, de tal sorte que a previsão dos direitos sociais, entre eles, e os direitos de nacionalidade e políticos, lhes quebra o formalismo e o sentido abstrato. Com isso, transita-se de uma democracia de conteúdo basicamente políticoformal para a democracia de conteúdo social, se não de tendência socializante (...). A antítese inicial entre direitos individuais e direitos sociais tende a resolver-se numa síntese de autêntica garantia para a democracia, na medida em que os últimos forem enriquecendo-se de conteúdo e eficácia".

43 'Força é dirimir, a esta altura, um eventual equívoco de linguagem: o vocábulo 'dimensão' substitui, com vantagem lógica e qualificativa, o termo 'geração', caso este último venha a induzir apenas sucessão cronológica e, portanto, suposta caducidade dos direitos das gerações antecedentes, o que não é verdade. Ao contrário, os direitos da primeira geração, direitos individuais, os da segunda, direitos sociais, e os da terceira, direitos ao desenvolvimento, ao meio ambiente, à paz e à fraternidade, permanecem eficazes, são infraestruturais, formam a pirâmide cujo ápice é o direito à democracia; coroamento daquela globalização política para a qual, como no provérbio chinês da grande muralha, a Humanidade parece caminhar a todo 
Em suma, as categorias ou dimensões de direitos fundamentais não se excluem, devendo ser vistas como um todo harmônico, fruto do processo de evolução do Direito.

Por fim, na ordem internacional, os direitos humanos são classificados em (i) direitos civis, (ii) direitos políticos, (iii) direitos econômicos, (iv) direitos culturais e, finalmente (v) direitos sociais. Estas espécies de direitos humanos foram definidas, de forma sucinta, acima, e são objeto de proteção pelo Pacto Internacional de Direitos Civis e Políticos e pelo Pacto Internacional de Direitos Econômicos, Sociais e Culturais.

\subsection{Características}

Partindo do pressuposto acima mencionado, de que os direitos humanos e os direitos fundamentais são expressões sinônimas, pode-se apontar como suas principais características as seguintes: (i) historicidade; (ii) irrenunciabilidade; (iii) imprescritibilidade; (iv) inalienabilidade; (v) indivisibilidade e (vi) universalidade; (vii) limitabilidade e (viii) aplicabilidade imediata de suas normas.

A característica da historicidade está intimamente ligada ao fato de os direitos fundamentais terem sofrido (e continuarem sofrendo) grande influência das mudanças sociais e políticas, conforme mencionado no tópico anterior.

Para se compreender a real extensão dos direitos fundamentais, necessária se faz uma incursão nos seus antecedentes históricos. Conforme já mencionado neste trabalho, a partir da Segunda Guerra Mundial, houve uma considerável evolução destas prerrogativas. Pode-se afirmar, inclusive, que o conteúdo destes direitos foi ampliado em razão do reconhecimento da pessoa como pertencente a três categorias diversas: a) a pessoa como ser humano; b) a pessoa como ser político e c) a pessoa como ser trabalhador.

A irrenunciabilidade, a imprescritibilidade e a inalienabilidade são atributos decorrentes do caráter não patrimonial e indisponível dos direitos fundamentais. Dessa maneira, ainda que o indivíduo queira abrir mão de um direito fundamental seu, o sistema 
de proteção dos direitos humanos não o permite, em clara demonstração de que a garantia dos direitos humanos transcende a vontade de seu titular. ${ }^{44}$

Ressalte-se que a indisponibilidade dos direitos humanos acarreta a sua irreversibilidade e, consequentemente, a impossibilidade jurídica de denúncia, por determinado Estado, de tratados que tenham por objeto a proteção dos direitos humanos (os quais serão objeto de estudo no próximo capítulo). Nesse sentido, merece menção a lição de Fábio Konder Comparato:

A consciência ética coletiva, como foi várias vezes assinalado aqui, amplia-se e aprofunda-se com o evolver da História. A exigência de condições sociais aptas a propiciar a realização de todas as virtualidades do ser humano é, assim, intensificada no tempo, e traduz-se, necessariamente, pela formulação de novos direitos humanos. É esse movimento de ampliação e aprofundamento que justifica o princípio da irreversibilidade dos direitos já declarados oficialmente, isto é, do conjunto de direitos fundamentais em vigor (...). Uma das conseqüências desse princípio é a proibição de pôr fim, voluntariamente, à vigência de tratados internacionais de direitos humanos. (...) Ora, o poder de denunciar uma convenção internacional só faz sentido quando esta cuida de direitos disponíveis. Em matéria de tratados internacionais de direitos humanos, não há nenhuma possibilidade jurídica de denúncia, ou de cessação convencional da vigência, porque se está diante de direitos indisponíveis e, correlatamente, de deveres insuprimíveis. ${ }^{45}$

A indivisibilidade dos direitos humanos, por sua vez, implica no reconhecimento de que "a garantia dos direitos civis e políticos é a condição para a observância dos direitos

\footnotetext{
${ }^{44} \mathrm{~A}$ indisponibilidade absoluta dos direitos fundamentais é combatida por parte da doutrina, que defende a posição de Alexy, conforme se percebe adiante: "Em algumas teorias dos direitos fundamentais, a disponibilidade ou a indisponibilidade fazem parte do próprio conceito de direito fundamental. Tal não é o que acontece na teoria alexyana, que apresenta uma versão bastante neutralizada dos direitos fundamentais, uma vez que os conceitua a partir de sua estrutura. Desta feita, pôde-se asseverar que, estruturalmente, as posições jurídicas subjetivas de direitos fundamentais não são nem disponíveis, nem indisponíveis. Disto se conclui que a disposição de posições jurídicas de direito fundamental é normativa e não conceitual. (...) Em suma, a conclusão é singela. Quando for aceita a tese da jusfundamentalidade do direito geral de liberdade em um ordenamento jurídico que não possuir enunciado normativo na Constituição estabelecendo a indisponibilidade dos Direitos Fundamentais, as posições jurídicas subjetivas de tais direitos são prima facie disponíveis. A proibição da disposição exigirá do Estado a apresentação dos motivos, que deverão ser argumentação suficiente para configurar uma restrição a direitos fundamentais. Caso não seja cumprido o ônus argumentativo, a proibição será uma violação e, portanto, inconstitucional" (MARTEL, Letícia de Campos Velho. São os Direitos Fundamentais Disponíveis? Reflexões à Luz da Teoria dos Direitos de Robert Alexy. In MARTEL, Letícia de Campos Velho. Estudos Contemporâneos de Direitos Fundamentais. Rio de Janeiro: Lumen Juris, 2009. Vol. II, pp. 65-66).

${ }^{45}$ COMPARATO, Fábio Konder. A Afirmação Histórica dos Direitos Humanos. $4^{\mathrm{a}}$ ed. São Paulo: Saraiva, 2005. p. 66-67.
} 
sociais, econômicos e culturais e vice-versa. Quando um deles é violado, os demais também o são". 46

Como bem lembrado por André de Carvalho Ramos, ${ }^{47}$ a indivisibilidade possui duas facetas: o reconhecimento de que os direitos humanos formam uma unidade incindível em si e que a proteção de um direito implica na garantia dos demais.

A universalidade é a característica dos direitos fundamentais que causa mais divergências na doutrina, apesar de vir expressamente prevista na Declaração Universal dos Direitos Humanos (1948), nos seguintes termos: “Todos os seres humanos nascem livres e iguais em dignidade e direitos. São dotados de razão e consciência e devem agir em relação uns aos outros com espírito de fraternidade" $\left(\operatorname{artigo~} 1^{\circ}\right)$.

A universalidade dos direitos humanos, nos dizeres de André de Carvalho Ramos, pode ser entendida em três planos:

O primeiro plano é o da titularidade. Assim, os direitos humanos são universais porque seus titulares são os seres humanos, sem distinção de qualquer ordem (religião, gênero, convicção política, raça, nacionalidade, entre outros). $\mathrm{O}$ segundo plano é temporal, no qual os direitos humanos são universais, pois os homens o possuem em qualquer época da história. Por fim, há o plano dito cultural, no qual os direitos humanos são universais porque permeiam todas as culturas humanas, em qualquer parte do globo. Os dois últimos planos advêm do reconhecimento do primeiro (...). ${ }^{48}$

Dessa maneira, o simples fato de os homens serem dotados de racionalidade e de dignidade os torna titulares de direitos humanos, vistos como um mínimo ético irredutível.

Frise-se que a universalidade dos direitos humanos, conforme abordado no item “a”, foi confirmada pela Declaração de Direitos Humanos de Viena (1993), ao estabelecer, em seu $\S 5^{\circ}$, que "Todos os direitos humanos são universais, interdependentes e interrelacionados. A comunidade internacional deve tratar os direitos humanos globalmente de forma justa e equitativa, em pé de igualdade e com a mesma ênfase".

\footnotetext{
${ }^{46}$ PIOVESAN, Flávia. Direitos Humanos: Desafios da Ordem Internacional Contemporânea. In PIOVESAN, Flávia (coord.). Direitos Humanos. Curitiba: Juruá, 2009. Vol. I, p. 18.

${ }^{47}$ CARVALHO RAMOS, André. Teoria Geral dos Direitos Humanos na Ordem Internacional. $2^{\mathrm{a}}$ ed. São Paulo: Saraiva, 2012. p. 163.

${ }^{48}$ CARVALHO RAMOS, André. Teoria Geral dos Direitos Humanos na Ordem Internacional. $2^{\mathrm{a}}$ ed. São Paulo: Saraiva, 2012. p. 146.
} 
A positivação da universalidade dos direitos humanos, entretanto, apesar de representar importante avanço, não foi suficiente para impedir as críticas doutrinárias, conforme se pode perceber pela leitura dos ensinamentos de Boaventura de Souza Santos:

\begin{abstract}
Mas serão os direitos humanos universais enquanto artefacto cultural, um tipo de invariante cultural ou transcultural, ou seja, parte de uma cultura global? A minha resposta é não. Em minha opinião, o único facto transcultural é a relatividade de todas as culturas. A relatividade cultural (não o relativismo) exprime também a incompletude e a diversidade cultural. Significa que todas as culturas tendem a definir como universal os valores que consideram fundamentais. $O$ que é mais elevado e importante é também o mais abrangentemente válido. Deste modo, a questão específica sobre as condições de universalidade numa dada cultura é, em si mesma, não-universal. A questão da universalidade dos direitos humanos é uma questão cultural do Ocidente. Logo, os direitos humanos são universais apenas quando olhados de um ponto de vista ocidental. Por isso mesmo, a questão da universalidade dos direitos humanos trai a universalidade do que questiona ao questioná-lo. O conceito de direitos humanos assenta num bem conhecido conjunto de pressupostos, todos eles tipicamente ocidentais, designadamente: existe uma natureza humana universal que pode ser conhecida racionalmente; a natureza humana é essencialmente diferente e superior à restante realidade; o indivíduo possui uma dignidade absoluta e irredutível que tem de ser defendida da sociedade ou do Estado; a autonomia do indivíduo exige que a sociedade esteja organizada de forma não hierárquica, como soma de indivíduos livres (PANIKKAR, 1984, p. 30 apud SANTOS, 2010). (...) A marca ocidental, ou melhor, a marca ocidental liberal do discurso dominante dos direitos humanos pode ser facilmente identificada: na Declaração Universal de 1948, elaborada sem a participação da maioria dos povos do mundo; no reconhecimento exclusivo de direitos individuais, como única excepção do direito colectivo à autodeterminação, o qual, no entanto, foi restringido aos povos subjugados pelo colonialismo europeu; na prioridade concedida aos direitos cívicos e políticos sobre os direitos económicos, sociais e culturais; e no reconhecimento do direito de propriedade como o primeiro e, durante muitos anos, o único direito económico. ${ }^{49}$
\end{abstract}

Os críticos do universalismo (sejam eles adeptos do relativismo ou não) negam a natureza universal dos direitos humanos, com base nos seguintes fundamentos: (i) filosófico: existem várias percepções valorativas do mundo, sendo os direitos humanos fundados única e exclusivamente na sua visão antropocêntrica; (ii) formal: a Declaração Universal dos Direitos Humanos não contou com a participação da maioria dos povos do mundo; (iii) geopolítico: os direitos humanos não passam de discurso político de relações exteriores de diversos Estados, em especial dos Estados Ocidentais, que se omitem sempre que o seu interesse particular demandar; (iv) cultural: os direitos humanos refletem a visão ocidental do mundo, sem considerar as particularidades culturais do Oriente e (v)

49 SANTOS, Boaventura de Souza. Para uma Concepção Intercultural dos Direitos Humanos. In SARMENTO, Daniel et al (coord). Igualdade, Diferença e Direitos Humanos. Rio de Janeiro: Lumen Juris, 2010. pp. 14-15. 
desenvolvimentista: os direitos humanos exigem um estágio mais avançado de desenvolvimento para a sua efetiva implementação. ${ }^{50}$

A leitura das observações acima deixa claro que o argumento cultural dos críticos ao universalismo dos direitos humanos deu origem e serviu de fundamento para a teoria do relativismo cultural. ${ }^{51}$ Como bem lembrado por Flávia Piovesan, ${ }^{52}$ para os relativistas,

Cada cultura possui seu próprio discurso acerca dos direitos fundamentais, que está relacionado às específicas circunstâncias culturais e históricas de cada sociedade. Não há moral universal, já que a história do mundo é a história de uma pluralidade de culturas.

Os óbices ao reconhecimento da universalidade dos direitos humanos, porém, não subsistem, quer porque é perfeitamente possível conciliar a natureza absoluta dos direitos humanos e a diversidade cultural, ${ }^{53}$ quer porque o Oriente estava devidamente representado

${ }^{50}$ Sobre o tema, conferir CARVALHO RAMOS, André. Teoria Geral dos Direitos Humanos na Ordem Internacional. $2^{\mathrm{a}}$ ed. São Paulo: Saraiva, 2012. pp. 150-156.

${ }^{51}$ A respeito do relativismo dos direitos humanos, conferir Jack Donnelly: “(...) Se os direitos humanos são baseados na natureza humana, no simples fato de que somos seres humanos, e se a natureza humana é universal, então como os direitos humanos podem ser relativos de uma maneira fundamental? A simples resposta para esta pergunta é que a natureza humana é, em alguma medida, culturalmente relativa (...). A natureza humana, nas perspectivas individual, do grupo e de espécies semelhantes, representa uma gama de possibilidades, variando em parte em resposta à cultura, sem limites psicobiológicos aparentes (...). Mesmo que todo comportamento fosse genético, a expressão do talento- que também é chamado de natureza humanaé, em sua grande maioria, determinada culturalmente" (DONNELLY, Jack. Cultural Relativism and Universal Human Rights. In Human Rights Quarterly, vol. 6, nº 4 , p. 403, 1994. Tradução livre).

${ }^{52}$ PIOVESAN, Flávia. Direitos Humanos: Desafios da Ordem Internacional Contemporânea. In PIOVESAN, Flávia. Direitos Humanos. Curitiba: Juruá, 2009. V1 I, p. 22.

53 Sobre a diversidade cultural, conferir MAZZUOLI, Valério de Oliveira. Tratados Internacionais de Direitos Humanos e Direito Interno. São Paulo: Saraiva, 2010, pp. 37-38: "Esse talvez seja o elemento mais complexo presente no mundo pós-moderno: a diversidade cultural. Daí a constante crítica filosófica e política que se tem voltado contra o emprego de um consenso 'como fundamento de qualquer construção teórica ou como elemento de legitimação de estruturas sociais e jurídicas, não apenas na esfera internacional, mas também no âmbito do direito interno', e cujo fundamento 'repousa, em última análise, na percepção de uma sociedade (interna e internacional) cada vez mais plural, dividida por concepções as mais diversas acerca de definições valorativas (o que é a justiça, o bem ou o belo), tendências políticas e ideológicas, opções pessoais de vida, dentre tantos outros aspectos'. Se é certo que os 'diferentes' obtiveram consideráveis vitórias desde o final da Segunda Guerra, não é menos certo que os seus problemas ainda não terminaram, principalmente quando se sabe que os conflitos surgidos entre essas 'diferenças' ainda têm sido resolvidos de modo a não respeitá-las (ou, melhor diríamos, de modo a não compreender que a diferença exige métodos também desiguais de solução de antinomias). Ao menos os sistemas (global e regionais) de proteção dos direitos humanos têm feito a sua parte, podendo-se mesmo dizer que se a igualdade internacionalmente postuladasobretudo pelas Convenções a ONU - ainda não é real, ela ao menos 'existe de jure em quase todos os países'. A diversidade cultural, cuja visualização tem se mostrado muito mais nítida após a revolução nas comunicações- a partir de quando povos e continentes então distantes passam a se aproximar-, tem causado grande impacto no direito em geral e no direito internacional em especial, o qual tem tido de se adaptar a tais 'diferenças' e procurado 'resolver' (até o momento sem muita metodologia, ainda que com certa dose de boa vontade) os conflitos que entre elas estão a surgir. É nítida, assim, a conexão entre cultura e direito, dado que 'os aspectos culturais influenciam decisivamente na validade e eficácia das normas jurídicas', além de reforçarem ou diminuírem "o grau de comprometimento em face dos três complexos de normas que constituem o direito internacional: as regras constitucionais ou princípios normativos fundamentais da 
quando da elaboração da Declaração Universal dos Direitos Humanos (1948). E, ainda que assim não fosse com relação ao segundo aspecto aqui mencionado, a universalidade dos direitos humanos, conforme já visto, foi confirmada pela Declaração de Viena (1993), que contou com a assinatura de diversos países do Ocidente e do Oriente. ${ }^{54}$

Ressalte-se, ademais, que os universalistas não negam a pluralidade cultural e a necessidade de se proteger a diversidade. Tanto isso é verdade que a Declaração Universal sobre a Diversidade Cultural (2002), em complementação à Declaração de Viena, ${ }^{55}$ previu, em seu artigo 4, que "A defesa da diversidade cultural é um imperativo ético, inseparável do respeito à dignidade humana. Ela implica o compromisso de respeitar os direitos humanos e as liberdades fundamentais (...)”.

Resta claro, assim, que a proteção da diversidade cultural pressupõe e é compatível com a universalidade dos direitos humanos, devendo haver um diálogo entre as duas concepções aqui mencionadas, de forma a melhor atender aos interesses dos indivíduos.

De acordo com o entendimento de Boaventura de Souza Santos ${ }^{56}$, o diálogo intercultural depende do reconhecimento das seguintes premissas, a saber: (i) superação do debate sobre o universalismo e o relativismo cultural; (ii) aceitação de que todas as

política mundial; as regras de coexistência e as regras de cooperação. De qualquer forma, o certo é que o direito internacional (notadamente o direito internacional dos direitos humanos) não tem permanecido imune a esse complexo de transformações atuais. Contudo, deve-se avançar no tema (e esse também é o papel da doutrina) e transformar a proteção de jure presente nas normas internacionais de direitos humanos também em proteção de facto, para somente assim garantir às diferenças a sua mais completa proteção".

${ }^{54}$ Foram signatários da Convenção de Viena os seguintes países: África do Sul, Albânia, Alemanha, Angola, Argélia, Argentina, Austrália, Áustria, Azerbaidjão, Bahamas, Barein Belarus (Bielo-Rússia), Bélgica, Bolívia, Bósnia-Herzegovina, Bulgária, Cabo-Verde, Cazaquistão, Chile, Cingapura, Colômbia, Coreia do Sul, Costa do Marfim, Costa Rica, Croácia, Cuba, Dinamarca, El Salvador, Equador, Eslováquia, Eslovênia, Estados Unidos, Estônia, Federação Russa, Filipinas, Finlândia, França, Gabão, Gana, Geórgia, Grécia, Guatemala, Guiana, Guiné-Bissau, Haiti, Holanda, Honduras, Hungria, Kuwait, Letônia, Líbia, Lituânia, Luxemburgo, Macedônia, Marrocos, México, Moldávia, Mônaco, Mongólia, Namíbia, Nicarágua, Níger, Noruega, Nova Zelândia, Panamá, Paquistão, Paraguai, Peru, Polônia, Portugal, Reino Unido (Inglaterra, Irlanda do Norte, Escócia e País de Gales), República Centro-Africana, República Democrática do Congo, República Checa, República Dominicana,

Romênia, San Marino, São Tomé e Príncipe, Seichelles, Senegal, Sérvia e Montenegro, Suécia, Suíça, Tadjiquistão,Tunísia, Turcomenistão, Ucrânia, Uruguai, Uzbequistão, Venezuela e Zimbábue.

55،A Declaração de Viena admitiu que as particularidades locais devem ser levadas em consideração, assim como os diversos contextos históricos, culturais e religiosos, mas é dever do Estado promover e proteger todos os direitos humanos, independentemente de seus sistemas políticos, econômicos e culturais. Logo, peculiaridades locais ou ocasionais não poderiam justificar a violação ou amesquinhamento desses direitos (...)" (CARVALHO RAMOS, André. Teoria Geral dos Direitos Humanos na Ordem Internacional. $2^{\mathrm{a}}$ ed. São Paulo: Saraiva, 2012. p. 148).

56 SANTOS, Boaventura de Souza. Para uma Concepção Intercultural dos Direitos Humanos. In SARMENTO, Daniel et al (coord). Igualdade, Diferença e Direitos Humanos. Rio de Janeiro: Lumen Juris, 2010. pp. 16-18. 
culturas possuem concepções de dignidade da pessoa humana, mas nem todas a enxergam como direito fundamental; (iii) todas as culturas são incompletas na sua concepção de dignidade humana; (iv) todas as culturas possuem versões diferentes da dignidade humana e (v) todas as culturas tendem a distribuir as pessoas e as classes sociais entre dois princípios: o da igualdade e o da diferença.

Frise-se que, apesar do autor mencionado negar a adoção quer da teoria da universalidade dos direitos humanos, quer da teoria do relativismo dos direitos humanos, a sua ideia do diálogo intercultural pode ser utilizada pelos adeptos do universalismo, que reconhecem a possibilidade de respeito e de garantia da diversidade cultural.

Ultrapassada a questão da universalidade dos direitos humanos, pode-se afirmar que esta modalidade de direitos, ademais de indivisível e universal, é interdependente. Isto significa que o conteúdo de um direito está relacionado ou decorre do conteúdo de outro, em clara demonstração de complementaridade.

Outrossim, os direitos humanos não são absolutos, no sentido de que admitem limitação em prol de direitos da mesma natureza.

A concepção de que os direitos fundamentais são absolutos resta ultrapassada, há anos, consoante demonstram os ensinamentos abaixo transcritos:

Os direitos humanos fundamentais, dentre eles os direitos e garantias individuais e coletivos consagrados no artigo $5^{\circ}$ da Constituição Federal, não podem ser utilizados como um verdadeiro escudo protetivo da prática de atividades ilícitas, nem tampouco como argumento para afastamento ou diminuição da responsabilidade civil ou penal por atos criminosos, sob pena de total consagração ao desrespeito a um verdadeiro Estado de Direito.

Os direitos e garantias fundamentais consagrados pela Constituição Federal, portanto, não são ilimitados, uma vez que encontram seus limites nos demais direitos igualmente consagrados pela Carta Magna (Princípio da relatividade ou convivência das liberdades públicas).

Desta forma, quando houver conflito entre dois ou mais direitos ou garantias fundamentais, o intérprete deve utilizar-se do princípio da concordância prática ou da harmonização, de forma a coordenar e combinar os bens jurídicos em conflito, evitando o sacrifício total de uns em relação aos outros, realizando uma redução proporcional do âmbito de alcance de cada qual (contradição dos princípios), sempre em busca do verdadeiro significado da norma e da harmonia do texto constitucional com sua finalidade precípua. ${ }^{57}$ (grifo no original)

\footnotetext{
${ }^{57}$ MORAES, Alexandre de. Direito Constitucional. $30^{a}$ ed. São Paulo: Atlas, 2014. pp. 30-31.
} 
Pode-se afirmar, assim, que havendo conflito entre direitos fundamentais cabe ao magistrado se valer da aplicação do princípio da proporcionalidade, fazendo prevalecer a norma que mais se adequar ao caso concreto, sem, contudo, nulificar a remanescente. $\mathrm{O}$ conflito de princípios constitucionais, diversamente do que ocorre na hipótese do conflito de regras, resolve-se com o sopesamento dos interesses em jogo. Nesse sentido:

Princípios contêm, normalmente, uma maior carga valorativa, um fundamento ético, uma decisão política relevante, e indicam uma determinada direção a seguir. Ocorre que, em uma ordem pluralista, existem outros princípios que abrigam decisões, valores ou fundamentos diversos, por vezes contrapostos. A colisão de princípios, portanto, não só é possível, como faz parte lógica do sistema, que é dialético. Por isso a sua incidência não pode ser posta em termos de tudo ou nada, de validade ou invalidade. Deve-se reconhecer aos princípios uma dimensão de peso ou importância. À vista dos elementos do caso concreto, o intérprete deverá fazer escolhas fundamentadas, quando se defronte com antagonismos inevitáveis, como os que existem entre a liberdade de expressão e o direito de privacidade, a livre iniciativa e a intervenção estatal, o direito de propriedade e a sua função social. A aplicação dos princípios se dá, predominantemente, mediante ponderação. ${ }^{58}$

Dessa maneira, o princípio da proporcionalidade representa um dos principais instrumentos de solução de conflitos entre normas de direitos fundamentais e vem sendo aplicado, com frequência, por nossos Tribunais ${ }^{59}$ e pelos Tribunais Internacionais, ${ }^{60}$ sendo o pilar da hermenêutica jurídica contemporânea.

58 BARROSO, Luis Roberto; BARCELLOS, Ana Paula de. O começo da história: a nova interpretação constitucional e o papel dos princípios no Direito Brasileiro. In SILVA, Virgílio Afonso da (org.). Interpretação Constitucional. São Paulo: Malheiros, 2005. p. 284.

59 "EMENTA. DNA. Submissão compulsória ao fornecimento de sangue para pesquisa do DNA. Estado da questão do direito comparado: precedente do STF que libera do constrangimento o réu em ação de investigação de paternidade (HC 71.373) e o dissenso dos votos vencidos: deferimento, não obstante o HC na espécie, em que se cuida de situação atípica na qual se pretende- de resto apenas para obter prova de reforçosubmeter o pai presumido, em processo que tem por objeto a pretensão de terceiro de ver-se declarado o pai biológico da criança nascida na constância do casamento do paciente. Hipótese na qual, à luz do princípio da proporcionalidade ou da razoabilidade, se impõe evitar a afronta à dignidade pessoal que, nas circunstâncias, a sua participação na perícia substantivaria" (STF, HC 76060-4-SC, $1^{\circ}$ Turma, DJ 15/05/1998, Ministro Relator Sepúlveda Pertence).

${ }^{60}$ Nas palavras de André de Carvalho Ramos, “A mais expressiva jurisprudência internacional sobre o uso do princípio da proporcionalidade na interpretação de direitos humanos é da Corte Europeia de Direitos Humanos, em que pese que a Convenção Europeia de Direitos Humanos não possui expressamente menção a esse princípio (...). A mecânica da aplicação do juízo de proporcionalidade pela Corte Europeia é a seguinte: em primeiro lugar, indaga se a intervenção estatal está prevista em lei e é eficaz em tese. Após, comprova se tal intervenção está justificada pela busca de fins legítimos. E, finalmente, analisa se a limitação ao direito era necessária em uma sociedade democrática. Em resumo, o uso da proporcionalidade concatena-se do seguinte modo: legalidade e idoneidade, necessidade em uma sociedade democrática e justo equilíbrio entre o benefício e o sacrifício gerado" (CARVALHO RAMOS, André. Teoria Geral dos Direitos Humanos na Ordem Internacional. $2^{\mathrm{a}}$ ed. São Paulo: Saraiva, 2012. p. 177). 
Por fim, as normas de direitos humanos possuem aplicabilidade imediata, com a finalidade de se garantir a efetividade de sua defesa. Neste contexto, o artigo $5^{\circ}, \S 1^{\circ}$, da Constituição de 1988 estabelece que "as normas definidoras dos direitos e garantias fundamentais têm aplicação imediata”.

Alguns doutrinadores sustentam que, apesar de a Constituição Federal estabelecer, de forma expressa, que as normas que veiculam os direitos e garantias fundamentais possuem aplicabilidade imediata, isto só ocorrerá se essas mesmas normas forem completas. Nesse sentido é o entendimento de Manoel Gonçalves Ferreira Filho: ${ }^{61}$

Louve-se a intenção dos constituintes, qual seja a de tentar impedir que os direitos não permaneçam como letra morta na Constituição, mas ganhem efetividade.

Contudo, o caminho escolhido não é suficiente em si para atender o objetivo colimado.

É lição da doutrina clássica, totalmente aceita, a de que nem toda norma constitucional é suscetível de aplicação imediata.

Donde se pode perfeitamente inferir que uma norma constitucional, mesmo definidora de direitos ou garantias fundamentais, somente pode ser aplicada se for completa.

(...)

A leitura dos vários incisos do art. $5^{\circ}$ facilmente demonstra a existência das normas definidoras de direitos "bastantes em si", ao lado de muitas outras normas "não bastantes em si".

A aplicação imediata das normas definidoras de direitos e garantias fundamentais tem por limite a natureza das coisas. Isto é, não pode ter aplicação imediata, diga o que disser a Constituição, uma norma incompleta. E a melhor prova disto é que a Constituição, que no art. $5^{\circ}, \S 2^{\circ}$, afirma solenemente a aplicação imediata das normas definidoras de direitos e garantias fundamentais, prevê no mesmo art. $5^{\circ}$, LXXI, um mandado de injunção para o caso em que direitos, liberdades e prerrogativas fundamentais inerentes à nacionalidade, à soberania e à cidadania não podem ser exercidos por falta de norma regulamentadora... (grifos do autor)

Percebe-se, assim, que para o autor aqui citado, as normas definidoras de direitos fundamentais, de qualquer categoria, podem não ser aplicáveis de forma imediata, em virtude de sua incompletude.

A posição acima mencionada, entretanto, sofre algumas variações. Alguns juristas sustentam que as normas que veiculam direitos individuais possuem aplicabilidade imediata, ao passo que as normas que veiculam direitos sociais ficam na dependência da

${ }^{61}$ FERREIRA FILHO, Manoel Gonçalves. Curso de Direito Constitucional. 24a ed. São Paulo: Saraiva, 1997. pp. 305-306. 
edição de lei regulamentadora para produzir efeitos jurídicos. Esta é a tese defendida por José Afonso da Silva: ${ }^{62}$

\begin{abstract}
A eficácia e aplicabilidade das normas que contêm os direitos fundamentais dependem muito de seu enunciado, pois se trata de assunto que está em função do Direito positivo. A Constituição é expressa sobre o assunto, quando estatui que as normas definidoras dos direitos e garantias fundamentais têm aplicação imediata. Mas certo é que isso não resolve todas as questões, porque a Constituição mesma faz depender de legislação ulterior a aplicabilidade de algumas normas definidoras de direitos sociais, enquadradas dentre os fundamentais. Por regra, as normas que consubstanciam os direitos fundamentais democráticos e individuais são de eficácia contida e aplicabilidade imediata, enquanto as que definem os direitos econômicos e sociais tendem a sê-lo também na Constituição vigente, mas algumas, especialmente as que mencionam uma lei integradora, são de eficácia limitada, de princípios programáticos e de aplicabilidade indireta, mas são tão jurídicas como as outras e exercem relevante função, porque quanto mais se aperfeiçoam e adquirem eficácia mais ampla, mais se tornam garantias da democracia e do efetivo exercício dos demais direitos fundamentais. (grifos do autor)
\end{abstract}

Em contraposição aos posicionamentos anteriormente mencionados, Ingo Wolfgang Sarlet defende que as normas que veiculam direitos sociais, da mesma forma que as normas que veiculam direitos individuais, possuem aplicabilidade imediata, uma fez que o Constituinte não fez qualquer distinção quanto aos regimes jurídicos a ela aplicáveis.

Desta feita, a aplicabilidade imediata das normas que veiculam direitos sociais (e, também, culturais e econômicos) encontra respaldo em argumentos literais e teleológicos, conforme se percebe pela leitura da citação abaixo:

(...) É possível partir da premissa de que a despeito da circunstância de que a localização topográfica do dispositivo poderia sugerir uma aplicação da norma contida no art. $5^{\circ}, \S 1^{\circ}$, da $\mathrm{CF}$ apenas aos direitos individuais e coletivos, o fato é que esse argumento não corresponde sequer à expressão literal do dispositivo, visto que esta utiliza a formulação genérica "normas definidoras de direitos e garantias fundamentais" (...).

(...) é possível verificar que também uma interpretação sistemática e teleológica conduzirá aos mesmos resultados. Nesse sentido, percebe-se, desde logo, que o Constituinte não pretendeu (nem é legítimo presumir isto!) excluir os direitos políticos de nacionalidade do âmbito do art. $5^{\circ}, \S 1^{\circ}$, de nossa Carta, que, assim como os direitos sociais, integram o conjunto dos direitos cuja fundamentalidade foi expressamente afirmada na Constituição. ${ }^{63}$ (grifos do autor)

${ }^{62}$ SILVA, José Afonso da. Curso de Direito Constitucional Positivo. $37^{\mathrm{a}}$ ed. São Paulo: Malheiros, 2014. p. 182.

${ }^{63}$ SARLET, Ingo Wolfgang. Os direitos sociais como direitos fundamentais: seu conteúdo, eficácia e efetividade no atual marco jurídico-constitucional brasileiro. In LEITE, George Salomão; SARLET, Ingo Wolfgang. Direitos Fundamentais e Estado Constitucional. Estudos em Homenagem a J.J. Gomes Canotilho. Coimbra: Coimbra Editora e Revista dos Tribunais, 2009. pp. 224-225. 
Dessa maneira, de acordo com a concepção acima exposta, mais garantista, todos os direitos fundamentais, estejam eles previstos ou não no corpo do artigo $5^{\circ}$, da $\mathrm{CF}$ ou, até mesmo, previstos ou não no texto constitucional, estão sujeitos ao mesmo regime jurídico, em virtude de sua fundamentalidade. Este regime jurídico determina que todas as normas que veiculam os direitos fundamentais possuem aplicabilidade imediata e funcionam como limites ao poder de reforma constitucional.

O próprio autor reconhece, porém, que a afirmação de que as normas que veiculam os direitos sociais possuem aplicabilidade imediata não é capaz de colocar uma pá de cal em todos os problemas referentes à matéria. Isto porque, a aplicabilidade imediata destas normas não dispensa, muitas vezes, a necessidade de edição de lei para a sua regulamentação.

Como justificativa para a solução do entrave aqui apresentado, Ingo Wolfgang Sarlet argumenta que as normas que veiculam direitos sociais possuem, muitas vezes, uma normatividade diferenciada- mais fraca-, por consagrarem, "em vez de direitos, normas impositivas de programas, fins e tarefas na esfera social". ${ }^{64}$ Este fato, entretanto, não impede a sua aplicabilidade imediata.

${ }^{64}$ SARLET, Ingo Wolfgang. Os direitos sociais como direitos fundamentais: seu conteúdo, eficácia e efetividade no atual marco jurídico-constitucional brasileiro. In LEITE, George Salomão; SARLET, Ingo Wolfgang. Direitos Fundamentais e Estado Constitucional. Estudos em Homenagem a J.J. Gomes Canotilho. Coimbra: Coimbra Editora e Revista dos Tribunais, 2009, p. 233. 


\title{
CAPÍTULO 2
}

\section{ABERTURA DOS DIREITOS FUNDAMENTAIS: TRATADOS INTERNACIONAIS ${ }^{65}$}

\subsection{Conceito}

\begin{abstract}
A Convenção de Viena ${ }^{66}(1969)$, em seu artigo $2^{\circ}$, dispõe que o tratado consiste no "acordo internacional celebrado por escrito entre Estados e regido pelo direito internacional, quer conste de um instrumento único, quer de dois ou mais instrumentos conexos, qualquer que seja a sua denominação particular”.
\end{abstract}

Do conteúdo de tratado, fornecido pela Convenção de Viena, podem ser extraídos os seguintes elementos, a saber:

(a) acordo internacional: a vontade é fundamental para a celebração dos tratados internacionais;

(b) celebrado por escrito: os tratados são acordos essencialmente formais, não podendo ser celebrados de forma diversa da escrita;

(c) concluído entre Estados ou organizações internacionais: apesar da Convenção de Viena de 1969 mencionar como sujeito de Direito Internacional apenas os Estados, a Convenção de Viena de 1986 ampliou a capacidade internacional para a celebração de

\footnotetext{
${ }^{65}$ Algumas das ideias defendidas neste Capítulo foram extraídas do trabalho de conclusão de curso apresentado na pós-graduação lato sensu em Direito Constitucional, intitulado "A inconstitucionalidade do processo judicial de adoção", em 2006.

66 "Chamada Lei dos Tratados, Código dos Tratados ou ainda Tratado dos Tratados, a Convenção de Viena de 1969 é um dos mais importantes documentos já concluídos na história do Direito Internacional Público. Ela não se limitou apenas à codificação do conjunto de regras gerais referentes aos tratados concluídos entre Estados, mas também se preocupou em regular todo tipo de desenvolvimento progressivo daquelas matérias ainda não consolidadas na arena internacional. A Convenção regula desde questões pré-negociais (capacidade para concluir tratados e plenos poderes), até o processo de formação dos tratados (adoção, assinatura, ratificação, adesão, reservas etc.), sua entrada em vigor, aplicação provisória, observância e interpretação, bem assim a nulidade, extinção e suspensão de sua execução (...). É curioso observar que a Convenção de Viena de 1969 reveste-se de autoridade jurídica mesmo para aqueles Estados que dela não são signatários, em virtude de ser ela geralmente aceita como norma "declaratória de Direito Internacional geral", expressando direito consuetudinário vigente, consubstanciado na prática reiterada dos Estados no que diz respeito à matéria nela contida. (...) mais de quarenta anos se passaram (de maio de 1969 a setembro de 2009) até que a Convenção de Viena sobre o Direito dos Tratados fosse formalmente ratificada pelo governo brasileiro. No entanto, mesmo antes de tal ratificação, o Itamaraty (de forma oficial) sempre pautou sua atividade na negociação de tratados pelas regras da Convenção de 1969 (e também pelas da Convenção de 1986)" (MAZZUOLI, Valerio de Oliveira. Curso de Direito Internacional Público. $7^{\mathrm{a}}$ ed. São Paulo: Revista dos Tribunais, 2013. pp. 183-185).
} 
tratados internacionais. Frise-se, porém, que as organizações internacionais só podem celebrar tratados relacionados às suas finalidades precípuas;

(d) regido pelo Direito Internacional: esta é uma das principais diferenças entre tratados e contratos internacionais, já que estes últimos são regidos "prioritariamente pelas normas do ordenamento jurídico interno de determinado Estado"; 67

(e) celebrado em instrumento único ou em dois ou mais instrumentos conexos: é possível que o tratado seja acompanhado de protocolos e/ou anexos e

(f) ausência de denominação específica: a configuração de um tratado depende da presença dos elementos aqui tratados e não da nomenclatura que lhe é dada.

Com fundamento na definição dada pela Convenção aqui referida, José Francisco Rezek afirma que "Tratado é todo acordo formal concluído entre sujeitos de direito internacional público, e destinado a produzir efeitos jurídicos "(...). ${ }^{68}$

Como se pode perceber pela leitura do conceito acima mencionado, apenas os sujeitos de direito internacional (Estados soberanos e organizações internacionais) podem celebrar tratados internacionais.

Frise-se que os Estados soberanos, ao firmarem um tratado internacional, devem ser representados pelos chefes de Estado (ou de Governo, dependendo do sistema adotado em cada país), uma vez que carecem de personalidade jurídica para tanto. No caso das organizações internacionais, o secretário-geral, ou o funcionário que, sob título diverso, encabeça o quadro administrativo da organização, é quem, em geral, e sob a autoridade da Assembleia Geral, conclui seus tratados. Esta prática tem sido adotada pela OEA e pelas congêneres de alcance regional.

No caso brasileiro, compete ao Chefe do Poder Executivo, de forma privativa, a celebração de tratados, nos termos do que dispõe o artigo 84, VII da Constituição Federal. Esta competência, porém, pode (e efetivamente o é) ser delegada aos Ministros das Relações Exteriores (Ministros dos Negócios Estrangeiros ou Assuntos Estrangeiros) ou

\footnotetext{
${ }^{67}$ MAZZUOLI, Valerio de Oliveira. Curso de Direito Internacional Público. $7^{\mathrm{a}}$ ed. São Paulo: Revista dos Tribunais, 2013. p. 193

${ }^{68}$ REZEK, José Francisco. Direito Internacional Público: curso elementar. $8^{a}$ ed. São Paulo: Saraiva, 2000. p. 14.
} 
aos Chefes de Missão Diplomática. Todo funcionário de carreira, entretanto, acreditado ou credenciado pelo país estrangeiro, pode ser agente plenipotenciário.

Neste sentido, o Decreto n. 99.578, de 10 de outubro de 1990, que regula a organização e o funcionamento do Ministério das Relações Exteriores, diz incumbir ao Itamaraty "negociar e celebrar, com a cooperação de outros órgãos interessados, tratados, acordos e demais atos internacionais" (art. $2^{\circ}, \mathrm{VI}$ ), sendo verdadeiro auxiliar do Presidente da República."69

Após a assinatura, entendida pela doutrina como "um aceite precário e formal, que não acarreta (saldo exceção do art. 12 da Convenção de 1969) efeitos jurídicos vinculantes", 70 pode o Presidente da República remeter o tratado internacional ao Congresso Nacional, a fim de que este o aprecie e dê sua aprovação. A assinatura do tratado, por si só, não obriga o Chefe do Executivo a submetê-lo à apreciação do Parlamento, podendo o processo de celebração ser interrompido.

Uma vez referendado pelo Congresso Nacional, o tratado retorna ao Poder Executivo para ratificação, nos seguintes termos:

\begin{abstract}
Concluída a negociação de um tratado, é certo que o Presidente da República está livre para dar curso, ou não, ao processo determinante do consentimento. Tudo quanto não pode o Presidente da República é manifestar o consentimento definitivo, em relação ao tratado, sem o abono do Congresso Nacional. Este abono, porém, não o obriga à ratificação. Isto significa, noutras palavras, que a vontade nacional, afirmativa quanto à assunção de um compromisso externo, repousa sobre a vontade conjugada de dois poderes políticos. A vontade individualizada de cada um deles é necessária, porém não suficiente. O êxito na Câmara e, em seguida, no Senado, significa que o compromisso foi aprovado pelo Congresso Nacional. Incumbe formalizar esta decisão do parlamento, e sua forma, no Brasil contemporâneo, é a de um decreto legislativo, promulgado pelo Presidente do Senado Federal, que o faz publicar no Diário Oficial da União. ${ }^{71}$
\end{abstract}

Consagra-se, assim, a colaboração entre Executivo e Legislativo na conclusão de tratados internacionais, que não se aperfeiçoa enquanto a vontade do Poder Executivo, manifestada pelo Presidente da República, não se somar à vontade do Congresso Nacional. Logo, os tratados internacionais demandam, para o seu aperfeiçoamento, um ato complexo, onde se integram a vontade do Presidente da

\footnotetext{
${ }^{69}$ MAZZUOLI, Valério de Oliveira. Direitos Humanos, Constituição e os Tratados Internacionais. Estudo analítico da situação e aplicação do Tratado na Ordem Jurídica Brasileira. São Paulo: Juarez de Oliveira, 2001.

${ }^{70}$ MAZZUOLI, Valerio de Oliveira. Curso de Direito Internacional Público. $7^{\text {a }}$ ed. São Paulo: Revista dos Tribunais, 2013. p. 230.

${ }^{71}$ REZEK, José Francisco. Direito Internacional Público: curso elementar. 8a ed. São Paulo: Saraiva, 2000. p. 64.
} 
República, que os celebra, e a do Congresso Nacional, que os aprova, mediante decreto legislativo. ${ }^{72}$

Há que se ressaltar, porém, que a conjugação das vontades do Poder Executivo e do Poder Legislativo, mencionadas acima, por si só, não é suficiente para que um tratado internacional passe a vigorar no território nacional. É necessário, ademais, que o tratado seja promulgado por um decreto do Presidente da República (ato de ratificação) e publicado no Diário Oficial da União.

A ratificação, conceituada como

$\mathrm{O}$ ato por meio do qual a mais alta autoridade do Estado, com competência constitucional para concluir tratados, confirma a assinatura do acordo elaborado pelos seus plenipotenciários e exprime, definitivamente, no plano internacional, a vontade do Estado em obrigar-se pelo tratado ${ }^{73}$

caracteriza-se como ato expresso, político, circunstancial, discricionário, irretroativo e irretratável.

Ultrapassadas estas etapas (assinatura, referendo do Poder Legislativo e ratificação, com posterior troca ou depósito), discute-se se o tratado internacional estaria automaticamente incorporado ao sistema interno, nele gerando efeitos jurídicos. Parte da doutrina sustenta que, após a ratificação, os tratados produzem efeitos jurídicos no plano interno e no plano internacional (teoria monista, adotada por diversos países da Europa), ao passo que outra parte defende que a ratificação só irradia efeitos no plano internacional, sendo necessário um ato jurídico interno para a incorporação do tratado no plano nacional (teoria dualista).

Não restam dúvidas de que a forma de incorporação dos tratados internacionais defendida pela teoria monista é "considerada como a mais efetiva e avançada sistemática de assegurar implementação aos tratados internacionais no plano interno". ${ }^{74}$ Entretanto, em razão da lacuna constitucional quanto a este assunto, grande parte da doutrina ${ }^{75}$ vem

\footnotetext{
${ }^{72}$ PIOVESAN, Flávia. Temas de Direitos Humanos. $4^{\mathrm{a}}$ ed. São Paulo: Saraiva, 2010. p. 109.

${ }^{73}$ MAZZUOLI, Valerio de Oliveira. Curso de Direito Internacional Público. $7^{\mathrm{a}}$ ed. São Paulo: Revista dos Tribunais, 2013. p. 237.

${ }^{74}$ PIOVESAN, Flávia. Temas de Direitos Humanos. $4^{\mathrm{a}}$ ed. São Paulo: Saraiva, 2010. p.108.

${ }^{75}$ Em sentido contrário, verificar MAZZUOLI, Valerio de Oliveira. Curso de Direito Internacional Público. $7^{a}$ ed. São Paulo: Revista dos Tribunais, 2013, p. 382: "Nunca houve regra expressa na história do constitucionalismo brasileiro a determinar que tratados ratificados pelo Presidente da República devessem ser
} 
defendendo que o Brasil adotou a teoria dualista no que se refere à incorporação dos tratados internacionais ao plano interno, sendo necessária a edição de um decreto de execução pelo Presidente da República.

A sistemática aqui mencionada não se aplica, no entanto, aos tratados internacionais de direitos humanos, em razão da existência de norma específica sobre a matéria, que dispõe sobre a sua aplicabilidade imediata (artigo $5^{\circ}, \S 1^{\circ}$ da Constituição Federal).

Nesse sentido, merecem destaque as palavras de Valerio de Oliveira Mazzuoli:

\begin{abstract}
Os tratados e instrumentos internacionais de proteção desenvolveram-se como resposta às arbitrariedades e violações de direitos humanos de diversos tipos. Esse conjunto normativo forma hoje um corpus juris totalmente autônomo de proteção, dotado de especificidade e de princípios próprios, sendo contrário à lógica do direito internacional clássico, feito pelos Estados e em prol dos próprios Estados. A lógica dos instrumentos internacionais de direitos humanos é diversa, à medida que visa a salvaguarda das pessoas e não das relações recíprocas entre os Estados. Daí ser a integração dessa normativa protetiva diversa da inserção formal de instrumentos internacionais no âmbito doméstico. Se, para estes últimos, se tem exigido uma formalidade executiva subsequente à ratificação, que no Brasil consiste na expedição de um decreto presidencial de execução antes da publicação do seu texto na imprensa oficial, para aqueles (para os tratados de direitos humanos) não se exige mais que a sua ratificação, que já é apta a internalizar- com aplicabilidade imediata- o tratado na órbita interna com efeitos vinculantes, no sentido de exigir diretamente do Estado que cumpra os direitos que ali se consagram e proteja as pessoas sujeitas à sua jurisdição de sua possível violação.

Contudo, não obstante este fato constatado, a integração de toda essa normativa internacional no Brasil nunca foi serena, tendo surgido problemas dos mais diversos relativamente à interpretação da Constituição em confronto com os tratados internacionais de direitos humanos já ratificados pelo governo, bem como problemas de ordem jurisprudencial deflagrados pela própria Suprema Corte, quando da aplicação prática desses mesmos instrumentos nos casos concretos em questão perante ela. Parece ainda faltar aos tribunais nacionais a correta compreensão dessa nova arquitetura internacional de proteção de direitos humanos veio exigir também novos princípios hermenêuticos e de resolução de controvérsias, em virtude da especialidade da matéria "direitos humanos" relativamente às demais normas dos ordenamentos interno e internacional, fato este que deve levar os jus-internacionalistas a propor novos métodos de solução
\end{abstract}

promulgados internamente, via decreto executivo, para que somente assim pudessem ter vigência e aplicabilidade internas. O Direito Internacional só necessita ser transformado em Direito interno quando o texto constitucional do país assim estabelece. Se a Constituição silencia a respeito, os tribunais nacionais estão aptos a aplicar, imediatamente, os tratados celebrados, se eles forem autoaplicáveis, a partir da ratificação. Neste caso, seria supérflua a promulgação, em virtude da inexistência de mandamento constitucional regulador da matéria. Ademais, não é correto dizer que a falta de promulgação executiva viola o princípio publicidade, pois uma vez ratificado o tratado deve o mesmo considerar-se público desde a data em que o Congresso Nacional o referendou, por meio de decreto legislativo, este sim previsto no rol das espécies normativas do art. 59 da Constituição. Nem se diga, ademais, que a publicação de qualquer norma é de competência exclusiva do Presidente da República (...)”. 
de antinomias quando se trata de conflitos entre normas de direito interno e de Direito Internacional dos Direitos Humanos. ${ }^{76}$ (grifo do autor)

Feitas estas considerações sobre o regime dos tratados internacionais, passa-se à análise da eficácia de suas normas.

\title{
2.2. Eficácia das normas dos tratados internacionais incorporados ao direito interno
}

Em razão da ausência de norma constitucional expressa a respeito da posição hierárquica dos tratados comuns perante o Direito Interno, a doutrina e a jurisprudência pátrias se dedicaram, durante anos, ao estudo do tema.

De acordo com a posição defendida por Hely Lopes Meirelles, os tratados internacionais, devidamente incorporados ao ordenamento jurídico interno, possuem eficácia de norma infraconstitucional, podendo se submeter ao controle de constitucionalidade. Nesse sentido:

\begin{abstract}
Os atos e tratados internacionais para serem incorporados ao ordenamento jurídico brasileiro necessitam de referendo do Congresso Nacional, via decreto legislativo e posterior edição de Decreto Presidencial, promulgando e publicando o ato. Devidamente incorporado, este ato normativo caracteriza-se como infraconstitucional para efeitos de controle de constitucionalidade. Conclui-se, portanto, pela supremacia das normas constitucionais em relação aos tratados a atos internacionais, mesmo que devidamente ratificados pelo Congresso Nacional e promulgados e publicados pelo Presidente da República e, consequentemente, plena possibilidade de incidência do controle de constitucionalidade. $^{77}$
\end{abstract}

Na mesma linha de raciocínio, o Supremo Tribunal Federal reconheceu a paridade hierárquica entre as normas previstas nos tratados internacionais comuns incorporados ao Direito Interno e as leis infraconstitucionais. Tanto isso é verdade, que, ao julgar a ADIN n. 1480 MC/DC ${ }^{78}$, que teve como relator o Ministro Celso de Melo, admitiu o controle de constitucionalidade dos tratados internacionais.

\footnotetext{
${ }^{76}$ MAZZUOLI, Valério de Oliveira. Tratados Internacionais de Direitos Humanos e Direito Interno. São Paulo: Saraiva, 2010. p. 27-28.

${ }_{77}^{77}$ SILVA, José Afonso da. Mandado de Segurança. $28^{\mathrm{a}}$ ed. São Paulo: Malheiros, 2005. p. 373.

78 Ementa: "Ação direta de inconstitucionalidade. Convenção no 158 OIT. Proteção do trabalhador contra a despedida arbitrária ou sem justa causa. Argüição de ilegitimidade dos atos que incorporaram esta convenção ao direito positivo interno do Brasil (decreto legislativo 68/92 e decerto 1855/96). Possibilidade de controle abstrato de constitucionalidade de tratados ou convenções internacionais em face da Constituição da
} 
A posição acima mencionada - de que os tratados internacionais comuns incorporados pelo ordenamento jurídico interno possuem validade e eficácia de lei ordinária federal -, entretanto, encontra resistência em parte da doutrina, que defende a supralegalidade destas normas. Nesse sentido:

\begin{abstract}
Dúvidas poderiam surgir quanto à consideração de serem os tratados comuns instrumentos de nível supralegal no Brasil. Poder-se-ia objetar não ter a Constituição disciplinado a hierarquia desses tratados em confronto com as demais leis da República. Mas basta verificar, num estudo comparativo, alguns dispositivos legais brasileiros para se poder concluir que o nosso sistema jurídico privilegia a superioridade de quaisquer tratados na ordem jurídica interna. Um desses dispositivos é o art. 5 do Código Penal Brasileiro, que desde 1940 acolhe essa tese, assim estatuindo: "Aplica-se a lei brasileira, sem prejuízo de convenções, tratados e regras de direito internacional, ao crime cometido no território nacional". Essa orientação da lei penal brasileira, de superioridade dos tratados internacionais em relação à legislação infraconstitucional foi seguida e reafirmada em 1941, também pelo Código de Processo Penal, que deixou assente, no seu art. $1^{\circ}$, inc. I, que o "processo penal reger-se-á, em todo o território brasileiro, por este Código, ressalvados os tratados, as convenções e regras de direito internacional". Ou seja, se o direito processual penal, no Brasil, rege-se pelo Código de Processo Penal, ressalvados os tratados, as convenções e regras de Direito Internacional, é porque tais instrumentos e regras de direito das gentes prevalecem sobre a legislação infraconstitucional, em relação a tais matérias. E, se prevalecem às regras do Código, é porque, evidentemente, estão acima delas. ${ }^{79}$ (grifos do autor)
\end{abstract}

Para aqueles que defendem a supralegalidade das normas previstas nos tratados comuns, o seu desrespeito dá causa ao que parte da doutrina convencionou denominar de controle de supralegalidade das normas. Nesse sentido:

República. Alegada a transgressão ao artigo $7^{\circ}$, I da Constituição da República e ao artigo 10, I do ADCT/88. Regulamentação normativa da proteção contra a despedida arbitrária ou sem justa causa, posta sob reserva constitucional de lei complementar. Conseqüente impossibilidade jurídica de tratado ou convenção internacional atuar como sucedâneo da lei complementar exigida pela Constituição. (...) CONTROLE DE CONSTITUCIOALIDADE DE TRATADOS INTERNACIONAIS NO SISTEMA JURÍDICO BRASILEIRO. O Poder Judiciário, fundado na supremacia da Constituição da República, dispõe de competência para, quer em sede de fiscalização abstrata, quer no âmbito do controle difuso, efetuar o exame de constitucionalidade dos tratados ou convenções internacionais já incorporados ao sistema de direito positivo interno. Doutrina e jurisprudência. PARIDADE NORMATIVA ENTRE ATOS INTERNACIONAIS E NORMAS INFRACONSTITUCIONAIS DE DIREITO INTERNO. Os tratados ou convenções internacionais, uma vez incorporados no direito interno, situam-se, no sistema jurídico brasileiro, nos mesmos planos de validade, de eficácia e de autoridade em que se posicionam as leis ordinárias, havendo, em conseqüência, entre estas e os atos de direito internacional público, mera relação de paridade normativa. Precedentes. No sistema jurídico brasileiro, os atos internacionais não dispõem de primazia hierárquica sobre as normas de direito interno. A eventual precedência de tratados ou convenções internacionais sobre as regras infraconstitucionais de direito interno somente se justificará quando a situação de antinomia com o ordenamento doméstico impuser, para a solução do conflito a aplicação alternativa do critério cronológico ou, quando cabível, do critério da especialidade. Precedentes (...). (grifo nosso).

${ }^{79}$ MAZZUOLI, Valerio de Oliveira. Curso de Direito Internacional Público. $7^{\mathrm{a}}$ ed. São Paulo: Revista dos Tribunais, 2013. p. 402. 


\begin{abstract}
A compatibilização das normas infraconstitucionais com os tratados internacionais comuns faz-se por meio do chamado controle de supralegalidade. Não se trata de controle de convencionalidade pelo fato de se reservar esta última expressão à compatibilidade vertical que devem ter as normas infraconstitucionais com os tratados de direitos humanos, que têm índole e nível constitucionais. Também não se trata de controle de legalidade, pelo fato de não estar em jogo a compatibilidade de norma infralegal com uma lei ordinária (v.g., a compatibilidade de um decreto com uma lei). No caso dos tratados internacionais comuns, estes estão abaixo da Constituição, mas acima das leis internas. Assim, eles passam a servir de paradigma de supralegalidade das normas domésticas, as quais também serão inválidas se violarem suas disposições.

(...) Pelo fato de não existir na Constituição qualquer menção expressa sobre o grau hierárquico dos tratados internacionais comuns, a outra solução não se pode chegar senão atribuir valor infraconstitucional (mas supralegal) a tais instrumentos. Assim, em relação aos tratados comuns o entendimento passa a ser o de que a lei interna não sucumbe ao tratado por ser ele posterior ou especial em relação a ela (pela aplicação daqueles critérios clássicos de solução de antinomias), mas sim em decorrência do status da supralegalidade desses tratados no plano doméstico. Nessa ordem de ideias, a lei posterior seria inválida (e, consequentemente, ineficaz) em relação ao tratado internacional, que não obstante anterior é hierarquicamente superior a ela. ${ }^{80}$
\end{abstract}

No que se refere aos tratados internacionais que tenham como objeto os direitos humanos, a posição acima mencionada não é pacífica, conforme se verá no tópico a seguir. $^{81}$

2.3. Tratados internacionais de direitos humanos: hierarquia normativa e interpretação

Com a edição da Carta de São Francisco (1945), após o final da Segunda Guerra Mundial, teve início o processo de internacionalização dos direitos humanos e a consequente sedimentação do Direito Internacional dos Direitos Humanos como ramo autônomo do Direito, assim definido por André de Carvalho Ramos: "O Direito Internacional dos Direitos Humanos consiste no conjunto de direitos e faculdades que garante a dignidade do ser humano e se beneficia de garantias internacionais institucionalizadas ". 82

\footnotetext{
${ }^{80}$ MAZZUOLI, Valerio de Oliveira. Teoria geral do controle de convencionalidade no direito brasileiro. In PIOVESAN, Flávia et al (coord.). Estudos Avançados de Direitos Humanos. Democracia e Integração Jurídica: Emergência de um novo Direito Público. Rio de Janeiro: Elsevier, 2013. pp. 775-776.

81 "No que diz respeito à hierarquia dos tratados, também percebe-se que a Carta Constitucional acolhe um sistema misto, de modo a conjugar regimes jurídicos diferenciados- um atinente aos tratados de direitos humanos e outros aos tratados internacionais" (PIOVESAN, Flávia. Temas de Direitos Humanos. $4^{\mathrm{a}}$ ed. São Paulo: Saraiva, 2010. p. 112).

${ }^{82}$ CARVALHO RAMOS, André. Teoria Geral dos Direitos Humanos na Ordem Internacional. $2^{\mathrm{a}}$ ed. São Paulo: Saraiva, 2012. p. 49.
} 
Antes da Carta de São Francisco foram editados alguns tratados sobre direitos humanos, mas estes eram específicos e não tinham alcance universal. Como exemplo, podem ser citadas as primeiras Convenções de Genebra, para a proteção de feridos e enfermos em tempo de Guerra.

A Carta de São Francisco, posteriormente regulamentada pela Declaração Universal de Direitos Humanos, foi o primeiro documento de caráter universal, que tinha como objeto a proteção da dignidade de todos os seres humanos. Nesse sentido:

(...) o passo decisivo para a internacionalização da temática dos direitos humanos foi a edição da Carta de São Francisco, que além de mencionar expressamente o dever de promoção de direitos humanos por parte dos Estados signatários, estabeleceu tal promoção como sendo um dos pilares da Organização das Nações Unidas (ONU), então criada. No preâmbulo da Carta, reafirma-se a fé nos direitos fundamentais do homem, na dignidade e no valor da pessoa humana, na igualdade de direitos de homens e mulheres. Os artigos 55 e 56, por seu turno, explicitam o dever de todos os Estados de promover os direitos humanos.

Assim, é a Carta de São Francisco, sem dúvida, o primeiro tratado de alcance universal que reconhece os direitos fundamentais de todos os seres humanos, impondo o dever dos Estados de assegurar a dignidade e o valor do ser humano. Pela primeira vez, o Estado era obrigado a garantir direitos básicos a todos sob a sua jurisdição, quer nacional ou estrangeiro. ${ }^{83}$

As atrocidades cometidas durante a Segunda Guerra Mundial e a posterior edição da Carta de São Francisco, que impôs aos Estados a promoção dos direitos humanos, representaram um giro copernicano nas relações internacionais ${ }^{84}$, que, até então, tinham como finalidade exclusiva o estabelecimento de direitos e deveres recíprocos aos Estados. $^{85}$

\footnotetext{
${ }^{83}$ Idem, ibidem. p. 49-50.

84 "A lógica que move a ratificação pelos Estados de um tratado internacional é a lógica das vantagens recíprocas. Grosso modo, em semelhança com a maioria dos contratos de Direito Privado, os tratados têm, em geral, natureza sinalagmática. Tal característica é estranha aos tratados de direitos humanos, pois neles há o objetivo de proteger os direitos dos indivíduos e estabelecer deveres aos Estados contratantes. Criou-se no contemporâneo Direito Internacional dos Direitos Humanos o chamado regime objetivo (não sinalagmático) dos tratados multilaterais de direitos humanos, pelo qual um Estado assume obrigações internacionais para com os indivíduos sob a sua jurisdição e não para os demais Estados" (CARVALHO RAMOS, André. Teoria Geral dos Direitos Humanos na Ordem Internacional. 2a ed. São Paulo: Saraiva, 2012. p. 63).

${ }^{85}$ Nesse sentido: CANÇADO TRINDADE, Antônio Augusto. A Humanização do Direito Internacional. Belo Horizonte: Del Rey, 2006, p. 27. "As sucessivas atrocidades e abusos que nas últimas décadas têm vitimado milhões de seres humanos em todas partes têm em definitivo despertado a consciência jurídica universal (como fonte material última de todo Direito) para a presente necessidade de reconceitualizar as próprias bases do direito internacional. Este último não se reduz, em absoluto, a um instrumental a serviço do poder; seu destinatário final é o ser humano, devendo atender a suas necessidades básicas, entre as quais se destaca a da realização da justiça. A emancipação da pessoa humana vis-à-vis o próprio Estado avança
} 
Como bem observado por Flávia Piovesan, ${ }^{86}$ o cenário acima narrado implicou na revisão da noção tradicional de soberania ${ }^{87}$ e no reconhecimento de que o ser humano deve ter os seus direitos protegidos na esfera internacional, independentemente da existência de vínculo de nacionalidade com determinado Estado. Em outras palavras,

As obrigações contidas nos tratados internacionais de direitos humanos extrapolam os limites físicos sobre os quais se assenta a soberania estatal, para ir além das fronteiras estatais e atingir toda a sociedade internacional de maneira erga omnes. ${ }^{88}$

Resta claro, assim, que a prioridade da ordem internacional passou a ser a proteção e a promoção dos direitos humanos e não a garantia dos interesses dos Estados soberanos. Nessa linha de raciocínio, merece destaque a lição de A. A. Cançado Trindade: ${ }^{89}$

Movida pela consciência humana, a própria dinâmica da vida internacional contemporânea tem cuidado de desautorizar o entendimento tradicional de que as relações internacionais se regem por regras derivadas inteiramente da livre vontade dos próprios Estados. O positivismo voluntarismo se mostrou incapaz de explicar o processo de formação das normas de Direito internacional geral, e se tornou evidente que só se poderia encontrar uma resposta ao problema dos fundamentos e da validade deste último na consciência jurídica, a partir da afirmação da idéia de uma justiça objetiva. Neste início de século XXI, temos o privilégio de testemunhar e o dever de impulsionar o processo de humanização do Direito Internacional, que, de conformidade com o novo ethos de nossos tempos, passa a se ocupar mais diretamente da identificação e realização de valores e metas comuns superiores.

Em atenção à relevância dos direitos humanos para o cenário interno e internacional, parte da doutrina sustenta que as normas dos tratados internacionais, que têm como objeto a proteção do ser humano, possuem a mesma eficácia das normas

lentamente, mas avança. Os avanços do ordenamento jurídico internacional correspondem à ascensão da consciência humana orientada à necessidade da realização do bem comum e da justiça".

${ }^{86}$ PIOVESAN, Flávia. Temas de Direitos Humanos. $4^{\text {a }}$ ed. São Paulo: Saraiva, 2010. p. 39.

87 "No campo das relações internacionais, a Declaração Universal, na esteira da Carta da ONU, alterou a clássica lógica da Paz de Westfália (1648). Esta lógica de Estados soberanos e independentes não atribuía peso a povos e indivíduos. Baseava-se nas relações de coexistência e conflito entre entes soberanos num sistema internacional de natureza intra-estatal. Este sistema criou as normas de mútua abstenção do Direito Internacional Público tradicional. (...) A Declaração é o primeiro texto de alcance internacional que trata de maneira abrangente da importância dos direitos humanos. É um marco na afirmação histórica da plataforma emancipatória do ser humano, representada pela promoção destes direitos como critério organizador e humanizador da vida coletiva na relação governante-governados. No plano internacional, representa um evento inaugural, à semelhança do que foi, a seu tempo, no plano interno, a passagem do dever dos súditos para os direitos dos cidadãos (...)" (LAFER, Celso. Declaração Universal dos Direitos Humanos (1948). In MAGNOLI, Demétrio (org.). História da Paz. São Paulo: Contexto, 2008. p. 297-299).

${ }^{88}$ MAZZUOLI, Valério de Oliveira. Tratados Internacionais de Direitos Humanos e Direito Interno. São Paulo: Saraiva, 2010. p. 31.

${ }^{89}$ CANÇADO TRINDADE, Antônio Augusto. A Humanização do Direito Internacional. Belo Horizonte: Del Rey, 2006. p. 96. 
constitucionais, não havendo que se falar em hierarquia entre estes tratados e a Carta Política vigente. Esta posição, porém, não é pacífica, convivendo com outras correntes doutrinárias que defendem (1) a eficácia legal dos tratados internacionais de direitos humanos; (2) a eficácia supralegal dos tratados internacionais de direitos humanos e, finalmente, (3) a eficácia supraconstitucional dos tratados internacionais de direitos humanos.

No Brasil, a eficácia constitucional dos tratados de direitos humanos é defendida, principalmente, pela professora Flávia Piovesan, nos seguintes termos:

\begin{abstract}
Neste debate, sustenta-se em prol da hierarquia constitucional dos tratados de proteção dos direitos humanos. Entende-se que, à luz do artigo $5^{\circ}$, parágrafo segundo, da Carta de 1988, os direitos fundamentais podem ser classificados em três distintos grupos: a) o dos direitos expressos na Constituição; b) o dos direitos implícitos, decorrentes do regime e dos princípios adotados pela Carta constitucional e c) o dos direitos expressos nos tratados internacionais subscritos pelo Brasil. A Constituição de 1988 inova, assim, ao incluir, dentre os direitos constitucionalmente protegidos, os direitos enunciados nos tratados internacionais de que o Brasil seja signatário. Ao efetuar tal incorporação, a Carta está a atribuir aos direitos internacionais uma hierarquia especial e diferenciada, qual seja a de norma constitucional (...). Esse tratamento jurídico diferenciado aos tratados de direitos humanos se justifica, na medida em que apresentam um caráter especial, distinguindo-se dos tratados internacionais comuns. Enquanto estes buscam o equilíbrio e a reciprocidade de relações entre Estados-partes, aqueles transcendem os meros compromissos recíprocos entre os Estados pactuantes, tendo em vista que objetivam a salvaguarda dos direitos do ser humano e não das prerrogativas dos Estados (...). Conclui-se, portanto, que o direito brasileiro faz opção por um sistema misto, que combina regimes jurídicos diferenciados: um regime aplicável aos tratados de direitos humanos e outro aplicável aos tratados tradicionais. Enquanto os tratados internacionais de proteção aos direitos humanos, por força do artigo $5^{\circ}$, parágrafo segundo, apresentam natureza de norma constitucional, os demais tratados internacionais apresentam natureza infraconstitucional. ${ }^{90}$
\end{abstract}

A posição acima, porém, ainda não foi acolhida pela jurisprudência majoritária do Supremo Tribunal Federal, que defende a tese de que os tratados internacionais de direitos humanos são dotados de supralegalidade. Nesse sentido, merece destaque a decisão abaixo transcrita, que trata da prisão civil do depositário infiel:

PRISÃO CIVIL DO DEPOSITÁRIO INFIEL EM FACE DOS TRATADOS INTERNACIONAIS DE DIREITOS HUMANOS. INTERPRETAÇÃO DA PARTE FINAL DO INCISO LXVII DO ART. 5O DA CONSTITUIÇÃO BRASILEIRA DE 1988. POSIÇÃO HIERÁRQUICO-NORMATIVA DOS

${ }^{90}$ PIOVESAN, Flávia. Reforma do Judiciário e Direitos Humanos. In TAVARES, André Ramos; LENZA, Pedro; ALARCÓN, Pietro de Jesús Lora (coords.). Reforma do Judiciário: analisada e comentada. São Paulo: Método, 2005. pp. 69-71. 
TRATADOS INTERNACIONAIS DE DIREITOS HUMANOS NO ORDENAMENTO JURÍDICO BRASILEIRO. Desde a adesão do Brasil, sem qualquer reserva, ao Pacto Internacional dos Direitos Civis e Políticos (art. 11) e à Convenção Americana sobre Direitos Humanos - Pacto de San José da Costa Rica (art. $7^{\circ}, 7$ ), ambos no ano de 1992, não há mais base legal para prisão civil do depositário infiel, pois o caráter especial desses diplomas internacionais sobre direitos humanos lhes reserva lugar específico no ordenamento jurídico, estando abaixo da Constituição, porém acima da legislação interna. $\mathrm{O}$ status normativo supralegal dos tratados internacionais de direitos humanos subscritos pelo Brasil torna inaplicável a legislação infraconstitucional com ele conflitante, seja ela anterior ou posterior ao ato de adesão. Assim ocorreu com o art. 1.287 do Código Civil de 1916 e com o Decreto-Lei ${ }^{\circ}$ 911/69, assim como em relação ao art. 652 do Novo Código Civil (Lei $\mathrm{n}^{\circ}$ 10.406/2002). ALIENAÇÃO FIDUCIÁRIA EM GARANTIA. DECRETO-LEI N ${ }^{\circ}$ 911/69. EQUIPAÇÃO DO DEVEDOR-FIDUCIANTE AO DEPOSITÁRIO. PRISÃO CIVIL DO DEVEDOR-FIDUCIANTE EM FACE DO PRINCÍPIO DA PROPORCIONALIDADE. A prisão civil do devedor-fiduciante no âmbito do contrato de alienação fiduciária em garantia viola o princípio da proporcionalidade, visto que: a) o ordenamento jurídico prevê outros meios processuais-executórios postos à disposição do credor-fiduciário para a garantia do crédito, de forma que a prisão civil, como medida extrema de coerção do devedor inadimplente, não passa no exame da proporcionalidade como proibição de excesso, em sua tríplice configuração: adequação, necessidade e proporcionalidade em sentido estrito; e b) o Decreto-Lei $\mathrm{n}^{\circ}$ 911/69, ao instituir uma ficção jurídica, equiparando o devedor-fiduciante ao depositário, para todos os efeitos previstos nas leis civis e penais, criou uma figura atípica de depósito, transbordando os limites do conteúdo semântico da expressão "depositário infiel" insculpida no art. $5^{\circ}$, inciso LXVII, da Constituição e, dessa forma, desfigurando o instituto do depósito em sua conformação constitucional, o que perfaz a violação ao princípio da reserva legal proporcional. RECURSO EXTRAORDINÁRIO CONHECIDO E NÃO PROVIDO. (RE 349703, Relator(a): Min. CARLOS BRITTO, Tribunal Pleno, julgado em 03/12/2008, DJe-104 DIVULG 04-06-2009 PUBLIC 05-06-2009 EMENT VOL-02363-04 PP-00675) (grifos nossos).

Com a finalidade de colocar uma pá de cal nas discussões doutrinárias travadas em torno da eficácia das normas dos tratados internacionais de direitos humanos incorporadas ao Direito Interno, a Emenda Constitucional 45/2004 acrescentou um parágrafo $3^{\circ}$ ao artigo $5^{\circ}$ da Carta Maior, nos seguintes termos: "Os tratados e convenções internacionais sobre direitos humanos aprovados, em cada Casa do Congresso Nacional, em dois turnos, por três quintos dos votos dos respectivos membros, serão equivalentes às emendas da Constituição".

Pela leitura do texto acima transcrito, pode-se concluir que, uma vez preenchidas as formalidades legais (aprovação, em cada casa do Congresso Nacional, em dois turnos, por três quintos dos votos dos respectivos membros), os tratados internacionais de direitos humanos terão a mesma eficácia das emendas constitucionais, que são normas constitucionais advindas do Poder Constituinte Reformador. Como bem elucida a teoria geral, as normas decorrentes do poder de reforma possuem o mesmo nível de eficácia das 
normas decorrentes do Poder Constituinte Originário. Afinal, para que uma norma constitucional se revista de eficácia máxima, basta que ela venha prevista na Constituição Formal. $^{91}$

Ressalte-se, porém, que, não obstante a boa vontade do legislador, a previsão da reforma não dirimiu os conflitos existentes acerca da hierarquia normativa dos tratados internacionais sobre direitos humanos. Há quem sustente, aliás, que a norma acabou por confirmar a posição de que os tratados internacionais possuem eficácia de lei ordinária, só se revestindo de caráter constitucional se for respeitado o mesmo procedimento legislativo das emendas constitucionais.

Dessa maneira, a inovação trazida pela Emenda Constitucional 45/2004 acabou fomentando as divergências já existentes acerca da recepção dos tratados internacionais de direitos humanos, em especial no que se refere aos tratados celebrados antes de sua promulgação. Alguns autores optaram pela interpretação meramente literal do texto da reforma, ao passo que outros se filiaram à interpretação sistemática. ${ }^{92}$

91 Nesse sentido, DALLARI, Pedro Bohomoletz de Abreu. Tratados Internacionais na Emenda Constitucional 45. In TAVARES, André Ramos et al (coord.). Reforma do Judiciário analisada e comentada. São Paulo: Método, 2005, p. 89: “Com o novo parágrafo $3^{\circ}$ do artigo $5^{\circ}$, estabelece-se, de forma inequívoca, conforme preceituado de forma literal, a possibilidade de que os tratados internacionais em matéria de direitos humanos tenham equivalência com a emenda constitucional, podendo acarretar, portanto, a agregação de novas normas ao sistema da Constituição ou mesmo a derrogação de normas que nele figurem. Mas isto desde que, quando da apreciação do tratado pelo Congresso Nacional, haja a aprovação na Câmara dos Deputados e no Senado Federal, em dois turnos em cada uma das Casas, e por pelo menos três quintos dos votos dos respectivos membros. Acolheu-se, assim, a tese de que os tratados sobre direitos humanos, dada a relevância da matéria, devem merecer acolhida diferenciada no direito brasileiro, mas procurou-se igualmente contemplar, por meio do quorum previsto para essa excepcionalidade, a lógica do processo legislativo, que exige maior endosso político à aprovação de normas jurídicas de maior posição hierárquica".

92 Dando primazia à interpretação sistemática, e não meramente literal do texto da reforma, Flávia Piovesan dispõe da seguinte maneira: "Desde logo, há que se afastar o entendimento de que, em face do parágrafo $3^{\circ}$ do artigo $5^{\circ}$, todos os tratados de direitos humanos já ratificados seriam recepcionados como lei federal, pois não teriam obtido o quorum qualificado de três quintos, demandado pelo aludido parágrafo. Reitere-se que, por força do artigo $5^{\circ}$, parágrafo $2^{\circ}$, todos os tratados de direitos humanos, independentemente do quorum de sua aprovação, são materialmente constitucionais. O quorum qualificado está tão-somente a reforçar tal natureza constitucional, ao adicionar um lastro formalmente constitucional. Na hermenêutica dos direitos há que se imperar uma lógica material e não formal, orientada por valores, a celebrar o valor fundante da prevalência da dignidade humana. Isto porque não seria razoável sustentar que os tratados de direitos humanos já ratificados fossem recepcionados como lei federal, enquanto os demais adquirissem hierarquia constitucional exclusivamente em virtude de seu quórum de aprovação" (PIOVESAN, Flávia. Reforma do Judiciário e Direitos Humanos. In TAVARES, André Ramos; LENZA, Pedro; ALARCÓN, Pietro de Jesús Lora (coords.). Reforma do Judiciário: analisada e comentada. São Paulo: Método, 2005. p. 72). 
Apesar de a controvérsia estar longe de ser dirimida, a posição que sustenta a eficácia constitucional de todos os tratados internacionais que versam sobre direitos humanos - acolhida neste trabalho - guarda mais compatibilidade com o sistema jurídico interno e com as normas de direito internacional que versam sobre direitos humanos.

Felizmente, quando teve a chance de reexaminar o assunto, após a promulgação da EC 45/2204, no julgamento do Habeas Corpus n. 87.585/TO, o Ministro Celso de Melo deixou de lado a posição de que os tratados internacionais de direitos humanos possuem eficácia legal e passou a defender que estes tratados, independentemente do quórum de sua aprovação no Congresso Nacional, possuem eficácia constitucional, sinalizando uma possível mudança de posicionamento da Corte Suprema sobre esse assunto. Diante da relevância e do pioneirismo deste voto, transcreve-se abaixo parte do mesmo:

\begin{abstract}
Após muita reflexão sobre esse tema, e não obstante anteriores julgamentos desta Corte de que participei como relator (RTJ 174/463-465 e RTJ 179/493-496) inclino-me a acolher essa orientação, que atribui natureza constitucional às convenções internacionais de direitos humanos, reconhecendo, para efeito de outorga dessa especial qualificação jurídica, tal como observa CELSO LAFER, a existência de três distintas situações concernentes a referidos tratados internacionais: (1) tratados internacionais de direitos humanos celebrados pelo Brasil (ou aos quais o nosso país aderiu), e regularmente incorporados à ordem interna, em momento anterior ao da promulgação da Constituição de 1988 (tais convenções internacionais revestem-se de índole constitucional, porque formalmente recebidas, nesta condição, pelo $\S 2^{\circ}$ do art. $5^{\circ}$ da Constituição); (2) tratados internacionais de direitos humanos que venham a ser celebrados pelo Brasil (ou aos quais o nosso país venha a aderir) em data posterior à da promulgação a EC 45/2004 (essas convenções internacionais, para se impregnarem de natureza constitucional, deverão observar o "iter" procedimental estabelecido pelo $\S 3^{\circ}$ do art. $5^{\circ}$ da Constituição); e (3) tratados internacionais de direitos humanos celebrados pelo Brasil (ou aos quais o nosso país aderiu) entre a promulgação da Constituição de 1988 e a superveniência da EC 45/2004 (referidos tratados assumem caráter materialmente constitucional, porque essa qualidade hierárquica jurídica lhes é transmitida por efeito de sua inclusão no bloco de constitucionalidade, que é "a somatória daquilo que se adiciona à Constituição escrita, em função dos valores e princípios nela consagrados).
\end{abstract}

Dessa maneira, pode-se afirmar que nosso ordenamento jurídico possibilita a convivência harmônica de duas categorias de tratados internacionais de direitos humanos: os tratados materialmente constitucionais e aqueles material e formalmente constitucionais (aprovados após a EC 45/2004).

Cumpre não olvidar, porém, que a adoção de uma ou outra teoria da hierarquia normativa dos tratados internacionais estudada neste item, longe de possuir consequências 
apenas acadêmicas, influencia diretamente no controle dos conflitos entre normas jurídicas. Isto porque, caso se admita que os tratados internacionais de direitos humanos possuam eficácia constitucional, as leis e demais atos normativos terão que guardar com eles relação de compatibilidade vertical, sob pena de serem objeto do controle de convencionalidade.

Nesta linha de raciocínio, “a compatibilidade do direito doméstico com os tratados internacionais de direitos humanos em vigor no país faz-se por meio do controle de convencionalidade" ${ }^{93}$, que, ao lado do controle de constitucionalidade, tem como finalidade compatibilizar as normas internas com aquelas incorporadas pelos tratados de direitos humanos ratificados pelo Brasil, antes ou após a nova normativa introduzida pela Emenda Constitucional n. 45/2004.

O controle de convencionalidade, a exemplo do que ocorre com o controle de constitucionalidade, pode ser difuso ou concentrado, a depender do fato de o tratado de direitos humanos, incorporado no plano interno, ser formal e materialmente constitucional ou apenas materialmente constitucional. Se o referido tratado for incorporado ao sistema interno por meio do procedimento previsto no parágrafo $3^{\circ}$ do artigo $5^{\circ}$ da Constituição Federal, o controle de convencionalidade poderá ser difuso (por qualquer órgão do Poder Judiciário) ou concentrado (pelo STF, sendo legitimados os mesmos órgãos ou entidades que podem requerer o controle de constitucionalidade concentrado). Caso o tratado seja apenas materialmente constitucional, o controle de convencionalidade poderá ser somente difuso. $^{94}$

\footnotetext{
${ }^{93}$ MAZZUOLI, Valerio de Oliveira. Teoria geral do controle de convencionalidade no direito brasileiro. In PIOVESAN, Flávia et al (coord.). Estudos Avançados de Direitos Humanos. Democracia e Integração Jurídica: Emergência de um novo Direito Público. Rio de Janeiro: Elsevier, 2013. p. 764.

${ }^{94}$ Nesse sentido, conferir MAZZUOLI, Valério de Oliveira. Tratados Internacionais de Direitos Humanos e Direito Interno. São Paulo: Saraiva, 2010, pp. 220-221: "Os tratados internacionais de direitos humanos ratificados pelo Brasil- independentemente de aprovação com quorum qualificado- tem "nível" de normas constitucionais e servem de paradigma de controle de constitucionalidade/convencionalidade, sendo a única diferença a de que os tratados aprovados pela maioria qualificada do $\S 3^{\circ}$ do art. $5^{\circ}$ da Constituição servirão de paradigma ao controle concentrado (para além, evidentemente, do difuso), enquanto os demais (tratados de direitos humanos não internalizados com aprovação congressual qualificada) apenas servirão de padrão interpretativo ao controle difuso (exceção ou defesa) de constitucionalidade/convencionalidade".
} 


\subsection{A interpretação dos tratados internacionais de direitos humanos e o diálogo das Cortes (ou das Fontes)}

Feitas as considerações acima, pode-se afirmar que questão relativa à recepção dos tratados internacionais de direitos humanos, apesar de ser dotada de extrema relevância e de ser objeto de inúmeros estudos jurídicos, não esgota o tema da aplicação dos direitos internacionais de direitos humanos no plano interno. Isto porque, ademais de se definir qual a eficácia da norma incorporada pelo ordenamento jurídico interno, é preciso garantir que o direito nela veiculado seja interpretado de acordo com as decisões emanadas das Cortes Internacionais.

Afinal, de nada adiantaria consolidar a tese de que as normas dos tratados internacionais de direitos humanos, devidamente incorporados pelo sistema interno, possuem eficácia de normas constitucionais, se a interpretação a elas dada pelo Poder Judiciário pátrio (especificamente pelo Supremo Tribunal Federal) for divergente daquela conferida pelos Tribunais Internacionais. Isto porque, a desconsideração da interpretação internacional dos direitos humanos acaba por acarretar violação à universalidade dos direitos humanos.

Como bem lembrado por André de Carvalho Ramos: ${ }^{95}$

De que adiantaria a Constituição pregar o respeito a tratados internacionais de direitos humanos se o Brasil continuasse a interpretar os direitos humanos neles contidos nacionalmente?

Nem preciso dizer que se todos os países que pregam o respeito à Declaração Universal de Direitos Humanos ou aos tratados de direitos humanos pudessem interpretar livremente seus comandos, então não existiria padrão universal de direitos, abrindo-se as portas para o relativismo.

Essa interpretação nacional desconectada da interpretação internacional destrói a própria essência da internacionalização dos direitos humanos, que consiste em impedir que as paixões de momento das maiorias - mesmo aquelas entronizadas nos órgãos judiciais máximos - possam sacrificar os direitos de todos. Por isso, a proteção de direitos humanos passou a ser tema internacional, em especial após a Carta da Organização das Nações Unidades de 1945 e a Declaração Universal de Direitos Humanos (1948).

95 CARVALHO RAMOS, André de. A Interpretação Internacional dos Direitos Humanos: Choque ou Diálogo com o Supremo Tribunal Federal? In BAPTISTA, Luiz Olavo; FERRAZ JUNIOR, Tércio Sampaio (coords.). Novos Caminhos do Direito no Século XXI. Direito Internacional, Filosofia Jurídica e Política, Dogmática Jurídica e Direitos Fundamentais. Uma Homenagem a Celso Lafer. Curitiba: Juruá, 2012. pp. 282-283. 
Sendo assim, a solução para a efetividade e a promoção dos direitos humanos em território nacional não é apenas a incorporação de suas normas internacionais, com eficácia de normas constitucionais, mas também e principalmente o diálogo entre as Cortes. ${ }^{96}$

Outrossim, a questão da interpretação dos tratados internacionais de direitos humanos não envolve apenas a conformidade do órgão julgador com as decisões internacionais. Quando se fala em interpretação internacional dos direitos humanos vêm à mente, também, os princípios que devem nortear a atividade jurisdicional.

Os métodos de interpretação, nos últimos anos, estão sendo objeto de diversos estudos, não só pela doutrina nacional como pela internacional. Com o reconhecimento da força normativa dos princípios, muito se falou na "nova interpretação constitucional" (“normatividade dos princípios", "ponderação de valores" ou "teoria da argumentação"). ${ }^{97}$

\footnotetext{
${ }^{96}$ Ainda sobre o tema, verificar Flávia Piovesan: “O diálogo jurisdicional em matéria de direitos humanos assume especial relevância e complexidade na ordem contemporânea, compreendendo o diálogo entre os sistemas regionais interamericano e europeu; entre os sistemas regionais e nacionais; e entre os sistemas nacionais. De um lado, constata-se a crescente tendência de abertura ao diálogo entre as Cortes Europeia e Interamericana baseado na referência recíproca de precedentes jurisprudenciais, no intercâmbio de argumentação jurídica e de experiências no enfrentamento de violações de direitos, culminando nos fenômenos da 'interamericanização' do sistema regional europeu e da 'europeização' do sistema regional interamericano. Por outro lado, no âmbito do diálogo entre as Cortes regionais e nacionais, emerge o instigante fenômeno do 'controle de convencionalidade', envolvendo o modo pelo qual as Cortes regionais exercem o controle de convencionalidade com relação às ordens jurídicas nacionais, bem como o modo pelo qual as Cortes nacionais exercem o controle de convencionalidade na esfera doméstica, mediante a incorporação da normatividade, da principiologia e da jurisprudência protetiva internacional em matéria de direitos humanos no contexto latino-americano. No campo dos direitos humanos e do diálogo jurisdicional também se destaca o diálogo horizontal a envolver jurisdições nacionais" (PIOVESAN, Flávia. Direitos Humanos e Diálogo Jurisdicional no Contexto Latino-americano. In BOGDANDY, Armin von; PIOVESAN, Flávia; ANTONIAZZI, Mariela Morales. Direitos Humanos. Democracia e Integração Jurídica: Emergência de um Novo Direito Público. Rio de Janeiro: Elsevier, 2013. p. 389).

97 “(...) a grande virada na interpretação constitucional deu-se a partir da difusão de uma constatação que, além de singela, sequer era original: não é verdadeira a crença de que as normas jurídicas em geral- e as normas constitucionais em particular - tragam sempre em si um sentido único, objetivo, válido para todas as situações sobre as quais incidem. E que, assim, caberia ao intérprete uma atividade de mera revelação do conteúdo preexistente na norma, sem desempenhar qualquer papel criativo na sua concretização. A nova interpretação constitucional assenta-se no exato oposto de tal proposição: as cláusulas constitucionais, por seu conteúdo aberto, principiológico e extremamente dependente da realidade subjacente, não se prestam ao sentido unívoco e objetivo que uma certa tradição exegética lhes pretende dar. O relato da norma, muitas vezes, demarca apenas uma moldura dentro da qual se desenham diferentes possibilidades interpretativas. À vista dos elementos do caso concreto, será determinado o sentido da norma, com vistas à produção da solução constitucionalmente adequada para o problema a ser resolvido" (BARROSO, Luis Roberto; BARCELLOS, Ana Paula de. O começo da história: a nova interpretação constitucional e o papel dos princípios no Direito Brasileiro. In SILVA, Virgílio Afonso da (org.). Interpretação Constitucional. São Paulo: Malheiros, 2005. p. 274-275).
} 
Na lição de Luís Roberto Barroso, ${ }^{98}$ os princípios de interpretação constitucional, considerados instrumentais, não estão expressamente previstos na Constituição (mas são amplamente reconhecidos pela doutrina e pela jurisprudência) e podem ser assim sistematizados: (i) princípio da supremacia da constituição; (ii) princípio da presunção de constitucionalidade das leis e atos do Poder Público; (iii) princípio da interpretação conforme a constituição; (iv) princípio da unidade da constituição; (v) princípio da razoabilidade ou da proporcionalidade e (vi) princípio da efetividade. ${ }^{99}$

O fato, entretanto, de as normas previstas nos tratados internacionais de direitos humanos, pela posição defendida neste trabalho, serem incorporadas ao sistema interno com eficácia de normas constitucionais não significa que os princípios de interpretação acima são os únicos que lhe são aplicáveis. Aplicam-se, também, aos tratados internacionais de direitos humanos os critérios previstos pela Convenção de Viena e os princípios extraídos da jurisprudência internacional.

De acordo com o artigo 32 da Convenção de Viena, os tratados internacionais devem ser interpretados de acordo com o texto, o momento de sua interpretação, o seu objeto e a sua finalidade, bem como a boa-fé das partes contratantes.

Percebe-se que os critérios estabelecidos pela Convenção de Viena para a interpretação dos tratados internacionais em muito se assemelham aos critérios tradicionais, previstos por nosso ordenamento jurídico interno (representado, exemplificativamente, pela Lei de Introdução do Código Civil, pelo Código Civil e pelo Código de Defesa do Consumidor).

Ademais dos critérios acima expostos, as Cortes Internacionais, no decorrer dos anos, entenderam que os tratados devem ser interpretados pelos seguintes princípios: (i) princípio da interpretação pro homine; (ii) princípio da efetividade; (iii) princípio da interpretação autônoma; (iv) princípio da interpretação evolutiva dos tratados de direitos

\footnotetext{
98 BARROSO, Luis Roberto; BARCELLOS, Ana Paula de. O começo da história: a nova interpretação constitucional e o papel dos princípios no Direito Brasileiro. In SILVA, Virgílio Afonso da (org.). Interpretação Constitucional. São Paulo: Malheiros, 2005. pp. 299-303.

99 Apesar da relevância destes princípios, a sua definição, por questões meramente didáticas, não será feita neste tópico, mas sim no decorrer do trabalho.
} 
humanos; (v) princípio da primazia da norma mais favorável ao indivíduo ${ }^{100}$. Frise-se, ademais, que a Corte Europeia de Direitos Humanos menciona como valioso instrumento de interpretação dos tratados internacionais a teoria da margem da apreciação.

Considerando-se que a ideia desse trabalho é buscar um entrosamento entre o ordenamento jurídico interno e o ordenamento jurídico internacional, com a finalidade de se garantir, da forma mais ampla possível, a efetividade dos direitos humanos- em especial, dos direitos das crianças e dos adolescentes- parece razoável sustentar que os Tribunais internos, ao se depararem com violações de normas de direitos humanos, previstas em tratados internacionais incorporados pelo Brasil, devem se valer dos princípios de interpretação constitucional e daqueles extraídos das decisões das Cortes Internacionais, a fim de alcançar a mais ampla proteção ao ser humano.

Nesta linha de raciocínio e com a finalidade de concluir este item, merecem menção os ensinamentos de Valerio de Oliveira Mazzuoli, ${ }^{101}$ acerca do diálogo das fontes:

\begin{abstract}
As relações pós-modernas entre o direito internacional e o direito interno devem afastar a excludência de uma norma pela outra e ceder à coexistência entre elas, além de também rechaçar todo tipo de intransigência quando o sujeito de direitos for um ser humano, dando então lugar ao "diálogo" entre tais fontes heterogêneas, para que melhor se proteja esse sujeito de direitos (...).

Estamos convictos de que o diálogo das fontes é condição necessária para a unidade sistêmica das ordens jurídicas à base dos direitos humanos, pois é sabido que "a paz, a estabilidade e a previsão dos comportamentos estão associadas ao valor da ordem na vida social, tais objetivos não se realizam se normas contraditórias fornecerem aos homens orientações opostas, deixando-os em situação de permanente incerteza". (...) Portanto, o que o diálogo entre as fontes faz é quebrar as barreiras que impedem a justiça no caso concreto, dando ao juiz a possibilidade de aplicar a norma que, no caso em exame, melhor atende aos direitos da pessoa humana (princípio internacional pro homine) e de julgar da maneira que lhe parece mais adequada. Evita-se, novamente, a solução única (ou mono-solução), para se permitir uma possibilidade plúrima de soluções, muito mais apta a reger o ordenamento jurídico pós-moderno. (grifos do autor)
\end{abstract}

Em suma, o diálogo entre as Cortes (ou diálogo das fontes, nos dizeres de Mazzuoli), aqui defendido, deve se dar no plano formal (instrumentos e princípios de

\footnotetext{
${ }^{100}$ Nesse sentido, conferir CARVALHO RAMOS, André. Teoria Geral dos Direitos Humanos na Ordem Internacional. $2^{\mathrm{a}}$ ed. São Paulo: Saraiva, 2012. pp. 80-100.

${ }^{101}$ MAZZUOLI, Valério de Oliveira. Tratados Internacionais de Direitos Humanos e Direito Interno. São Paulo: Saraiva, 2010, pp. 149-150. O autor classifica o diálogo das fontes em horizontal, quando as normas internacionais complementam o direito interno, por não serem contrárias a ele, e vertical, quando a norma internacional conflita com o direito interno ou prevê norma que o direito interno não vislumbrou.
} 
interpretação) e no plano material (decisão extraída da interpretação), com a finalidade de se garantir, da forma mais ampla possível, a proteção do ser humano.

\subsection{Proteção Internacional dos Direitos das Crianças e dos Adolescentes}

A proteção internacional ${ }^{102}$ dos direitos das crianças e dos adolescentes se dá de forma geral e específica e de forma global e regional. ${ }^{103}$

No plano geral e global, a Declaração Universal dos Direitos Humanos, promulgada em 1948 pela Assembleia Geral da Organização das Nações Unidas, com a finalidade de regulamentar a Carta de São Francisco, estabeleceu que "Todos os seres humanos nascem livres e iguais em dignidade e direitos. São dotados de razão e

102 O professor Gustavo Ferraz de Campos Mônaco, em sua obra A Proteção da Criança no Cenário Internacional, se vale de classificação da proteção internacional parcialmente divergente da aqui adotada. Nas palavras do autor: “(...) As normas de direito internacional dos direitos humanos podiam ser normas de vocação ou origem global ou normas de vocação ou origem regional. Essa classificação tem o condão de esgotar todos os instrumentos internacionais de proteção dos direitos humanos, posto que em cada um deles seja possível reconhecer a sua vocação para vigorar em todo o globo ou a sua vocação para vigorar em uma região delimitada do planeta. Por outro lado, esses mesmos instrumentos internacionais podem ser divididos, novamente, segundo o alcance subjetivo que podem ter, ou seja, segundo a sua aptidão para proteger direitos reconhecidos a todos os seres humanos (de todo o globo ou de uma região do planeta) ou a apenas algum grupo em especial (grupo este que pode gozar tanto de proteção global quanto de proteção regional para seus direitos humanos). Essas classificações, portanto, não se excluem, mas antes se complementam, admitindo uma combinação de seus traços característicos que acaba por permitir a formação de quatro grandes sistemas de proteção: um sistema global e homogêneo (que encerra em si o verdadeiro universalismo), um sistema global e heterogêneo (como é o sistema que esse trabalho se propõe sistematizar em sua segunda parte), um sistema regional e homogêneo e, por fim, um outro sistema, de mais difícil verificação factual, que é regional e heterogêneo" (MÔNACO, Gustavo Ferraz de Campos. A Proteção da Criança no Cenário Internacional. Belo Horizonte: Del Rey, 2005. pp. 118-119).

103 “O processo de universalização dos direitos humanos permitiu a formação de um sistema internacional de proteção desses direitos. Esse sistema é integrado por tratados internacionais de proteção que refletem, sobretudo, a consciência ética contemporânea compartilhada pelos Estados, na medida em que invocam o consenso internacional acerca de temas centrais aos direitos humanos, na busca da salvaguarda de parâmetros protetivos mínimos- do 'mínimo ético irredutível'. Ao lado do sistema normativo global, surgem os sistema regionais de proteção, que buscam internacionalizar os direitos humanos nos planos regionais, particularmente na Europa, América e África. Consolida-se, assim, a convivência do sistema global da ONU com instrumentos do sistema regional, por sua vez, integrado pelos sistemas interamericano, europeu e africano de proteção aos direitos humanos.Os diversos sistemas de proteção dos direitos humanos interagem em benefício dos indivíduos protegidos. Ao adotar o valor da primazia da pessoa humana, esses sistemas se complementam, somando-se ao sistema nacional de proteção, a fim de proporcionar a maior efetividade possível na tutela e promoção dos direitos fundamentais. Essa é inclusive a lógica e principiologia próprias do Direito dos Direitos Humanos. No que se refere à posição do Brasil, em relação ao sistema internacional de proteção dos direitos humanos, cabe realçar que somente a partir do processo de democratização do país, deflagrado em 1985, é que o Estado brasileiro passou a ratificar relevantes tratados internacionais de direitos humanos" (SARMENTO, Daniel. Direito Constitucional e Igualdade Étnico-Racial. In PIOVESAN, Flávia; SOUZA, Douglas Martins de. Ordem Jurídica e Igualdade Étnico-Racial. Rio de Janeiro: Lumen Juris, 2008. pp. 21-22). 
consciência e devem agir em relação uns aos outros com espírito de fraternidade" (artigo $1^{\mathrm{o})}$.

Em outras palavras, a Declaração Universal de Direitos Humanos reconheceu que toda pessoa é titular de direitos, independentemente da existência de vínculo de nacionalidade com determinado Estado, ${ }^{104}$ pela simples razão de ser dotada de dignidade.

Percebe-se, assim que a Declaração Universal de Direitos Humanos tem como finalidade garantir a proteção da pessoa humana, independentemente de sexo, cor, idade, religião ou opinião política.

No que diz respeito ao objeto deste trabalho, a Declaração Universal dos Direitos Humanos demonstra preocupação com a proteção da família e da infância nos artigos XVI e XXV, item 2, nos seguintes termos, respectivamente:

1. Os homens e mulheres de maior idade, sem qualquer restrição de raça, nacionalidade ou religião, têm direito a contrair matrimônio e fundar uma família, Gozam de iguais direitos em relação ao casamento, sua duração e sua dissolução.

2. O casamento não será livre senão com o livre e pleno consentimento dos nubentes.

3. A família é o núcleo natural e fundamental da sociedade e tem direito à proteção da sociedade e do Estado.

4. A maternidade e a infância têm direito a cuidados e assistência especiais. Todas as crianças, nascidas dentro ou fora do matrimônio, gozam da mesma proteção social.

O Pacto Internacional sobre Direitos Civis e Políticos, adotado pela Assembleia Geral das Nações Unidas em 1966, com a finalidade de desenvolver de forma pormenorizada a Declaração Universal dos Direitos Humanos, prevê, em seu artigo 23, dispositivo muito semelhante ao mencionado acima. Acrescenta, entretanto, a necessidade de proteção dos filhos quando da dissolução do casamento.

Para melhor comparação das duas disposições, transcreve-se abaixo a redação integral do artigo 23, mencionado acima:

\footnotetext{
${ }^{104}$ Conferir ALMEIDA, Guilherme Assis de. Mediação, proteção local dos direitos humanos e prevenção da violência. In Revista Brasileira de Segurança Pública, ano 1, edição 2, pp. 137-138, 2007.
} 
1. A família é o elemento natural e fundamental da sociedade e terá o direito de ser protegida pela sociedade e pelo Estado.

2. Será reconhecido o direito do homem e da mulher de, em idade núbil, contrair casamento e constituir família.

3. Casamento algum será celebrado sem o consentimento livre e pleno dos futuros esposos.

4. Os Estados-Partes do presente Pacto deverão adotar as medidas apropriadas para assegurar a igualdade de direitos e responsabilidade dos esposos quanto ao casamento, durante o mesmo e por ocasião de sua dissolução. Em caso de dissolução, deverão adotar-se disposições que assegurem a proteção necessária para os filhos.

Outrossim, diversamente do que ocorreu com a DUDH, o Pacto Internacional de Direitos Civis e Políticos previu um artigo específico (artigo 24) destinado à proteção das crianças, consideradas como sujeitos de direitos e não como meros instrumentos da vontade dos pais. Nesse sentido:

1. Toda criança terá direito, sem discriminação alguma por motivo de cor, sexo, língua, religião, origem nacional ou social, situação econômica ou nascimento, às medidas de proteção que a sua condição de menor requer por parte de sua família, da sociedade e do Estado.

2. Toda criança deverá ser registrada imediatamente após o seu nascimento e deverá receber um nome.

3. Toda criança terá o direito de adquirir uma nacionalidade.

De forma complementar, o Pacto Internacional sobre Direitos Econômicos, Sociais e Culturais, adotado pela Assembleia Geral das Nações Unidas também em 1966, prevê a garantia dos direitos sociais e assistenciais da família e das crianças, nos seguintes termos:

Os Estados-Partes do presente Pacto reconhecem que:

1. Deve-se conceder à família, que é o elemento natural e fundamental da sociedade, a mais ampla proteção e assistência possíveis, especialmente para a sua constituição e enquanto ela for responsável pela criação e educação dos filhos. O matrimônio deve ser constituído com o livre consentimento dos futuros cônjuges.

2. Deve-se conceder proteção especial às mães por um período de tempo razoável antes e depois do parto. Durante esse período, deve-se conceder às mães que trabalham licença remunerada ou licença acompanhada de benefícios previdenciários adequados.

3. Devem-se adotar medidas especiais de proteção e assistência em prol de todas as crianças e adolescentes, sem distinção alguma por motivo de filiação ou qualquer outra condição. Devem-se proteger as crianças e adolescentes contra a exploração econômica e social. O emprego de crianças e adolescentes em trabalhos que lhes sejam nocivos à moral e à saúde ou que lhes façam correr perigo de vida, ou ainda que lhes venham a prejudicar o desenvolvimento normal, será punido por lei.

4. Os Estados devem também estabelecer limites de idade sob os quais fique proibido e punido por lei o emprego assalariado da mão-de-obra infantil. 
A leitura comparativa destes dispositivos deixa claro que, em razão da existência de um lapso temporal de dezoito anos entre os documentos que os veiculam, os direitos das crianças vêm regulamentados de forma mais específica nos Pactos promulgados pela Assembleia Geral das Nações Unidas. Nestes fica evidente que se a família é elemento fundamental da sociedade, a criança é seu elemento central.

Por óbvio, os demais direitos previstos nos documentos acima mencionados também se aplicam às crianças e aos adolescentes, em razão da natureza geral dos mesmos. Como exemplo, é possível citar o direito à vida, à liberdade, à igualdade, ao devido processo legal, ao contraditório, à educação, ao trabalho, ao lazer, à cultura, dentre outros.

No plano geral e regional, deve ser mencionada a Convenção Americana de Direitos do Homem, aprovada na Conferência de São José da Costa Rica, aos 22 de novembro de 1969, que repete, quase na íntegra, os dispositivos mencionados pelos Pactos aprovados pela Assembleia Geral das Nações Unidas.

Analisadas algumas das normas previstas no plano geral, que não esgotam o âmbito de proteção do ser humano, é possível se adentrar no estudo das normas internacionais específicas, ${ }^{105}$ voltadas à proteção das crianças e dos adolescentes, em virtude do reconhecimento de sua condição de vulnerabilidade. ${ }^{106}$

\footnotetext{
105 “A primeira fase de proteção dos direitos humanos foi marcada pela tônica da proteção geral, que expressava o temor da diferença (que no nazismo havia sido orientada para o extermínio), com base na igualdade formal. Torna-se, contudo, insuficiente tratar o indivíduo de forma genérica, geral e abstrata. Fazse necessária a especificação do sujeito de direito, que passa a ser visto em sua peculiaridade e particularidade. Nesta ótica, determinados sujeitos de direitos, ou determinadas violações de direitos, exigem uma resposta específica e diferenciada. Neste cenário, as mulheres, as crianças, a população afrodescendente, os migrantes, as pessoas portadoras de deficiência, dentre outras categorias vulneráveis, devem ser vistas nas especificidades e peculiaridades de sua condição social. Ao lado do direito à igualdade, surge, também, como direito fundamental, o direito à diferença. Importa o respeito à diferença e à diversidade, o que lhes assegura um tratamento especial" (PIOVESAN, Flávia. Direitos Humanos: Desafios da Ordem Internacional Contemporânea. In PIOVESAN, Flávia. Direitos Humanos. Curitiba: Juruá, 2009. V1 I, p. 31-32).

${ }^{106}$ Como bem lembrado por Gustavo Ferraz de Campos Mônaco; “(...) não bastará que um dado grupo de seres humanos se mostre minoritário para que receba a proteção especializada do sistema heterogêneo de direitos humanos. Por outro lado, mesmo grupos minoritários poderão ser objeto de proteção heterogênea, sem que disso advenha qualquer conclusão definitiva. Ou seja, não são as minorias que são protegidas, muito embora elas possam receber proteção diferenciada, de natureza heterogênea. Basta, para tanto, que os grupos minoritários estejam em uma situação que autorize a discriminação positiva ou afirmativa (é o que se passa, por exemplo, no âmbito do direito humanitário). Essa situação autorizadora pode ser genericamente chamada de situação de hipossuficiência, em que o grupo social se mostra, aos olhos da sociedade, como um grupo que necessita de cuidados especiais, que desemboca numa proteção, também ela especial. Nesse sentido, então, as crianças não constituem um grupo minoritário. As crianças são, isso sim, uma categoria de seres humanos que faz jus, segundo a decisão da sociedade internacional, à proteção heterogênea dispensada a
} 
A Convenção sobre os Direitos da Criança, adotada pela ONU em 1989, com a finalidade de regulamentar a Declaração sobre os Direitos da Criança (1959), ${ }^{107}$ reconhece a criança como sujeito de direitos e prevê o princípio do melhor interesse da criança em

diversos dispositivos. Como exemplo, podem ser citados os artigos $3^{\circ}, 18,201$ e 21, respectivamente e abaixo transcritos:

1. Todas as ações relativas às crianças, levadas a efeito por instituições públicas ou privadas de bem estar social, tribunais, autoridades administrativas ou órgãos legislativos, devem considerar, primordialmente, o interesse maior da criança.

2. Os Estados Partes se comprometem a assegurar à criança a proteção e o cuidado que sejam necessários para seu bem-estar, levando em consideração os direitos e deveres de seus pais, tutores ou outras pessoas responsáveis por ela perante a lei e, com essa finalidade, tomarão todas as medidas legislativas e administrativas adequadas.

3. Os Estados Partes se certificarão de que as instituições, os serviços e os estabelecimentos encarregados do cuidado ou da proteção das crianças cumpram com os padrões estabelecidos pelas autoridades competentes, especialmente no que diz respeito à segurança e à saúde das crianças, ao número e à competência de seu pessoal e à existência de supervisão adequada.

1. Os Estados Partes envidarão os seus melhores esforços a fim de assegurar o reconhecimento do princípio de que ambos os pais têm obrigações comuns com relação à educação e ao desenvolvimento da criança. Caberá aos pais ou, quando for o caso, aos representantes legais, a responsabilidade primordial pela educação e pelo desenvolvimento da criança. Sua preocupação fundamental visará ao interesse maior da criança (...).

1. As crianças privadas temporária ou permanentemente do seu meio familiar, ou cujo interesse maior exija que não permaneçam nesse meio, terão direito à proteção e assistência especiais do Estado.

2. Os Estados Partes garantirão, de acordo com suas leis nacionais, cuidados alternativos para essas crianças.

3. Esses cuidados poderiam incluir, inter alia, a colocação em lares de adoção, a kafalah do direito islâmico, a adoção ou, caso necessário, a colocação em instituições adequadas de proteção para as crianças. Ao serem consideradas as soluções, deve-se dar especial atenção à origem étnica, religiosa, cultural e

alguns grupos hipossuficientes" (MÔNACO, Gustavo Ferraz de Campos. A Proteção da Criança no Cenário Internacional. Belo Horizonte: Del Rey, 2005. p. 121).

107 “A Declaração dos Direitos da Criança, adotada pela Resolução 1386 (XIV) da AGNU, de 20.11.1959, é composta por dez princípios cuidadosamente elaborados, pois traz tacitamente alguns preceitos já demonstrados pela Declaração de Genebra de 1924, pela Declaração Universal de 1948 e demais legislações, reafirmando o propósito de proporcionar às crianças os devidos cuidados que sua imaturidade necessita, antes e após o nascimento. Relembra, ainda, o compromisso assumido pelos povos de respeitar e defender a pessoa humana nos referidos documentos. A Declaração possui como finalidade garantir o direito a uma infância feliz, objetivando o reconhecimento pelos governos e pela sociedade. A Declaração dos Direitos das Crianças de 1959 marcou o início da nova concepção da criança como sujeito do processo, titular de direitos e obrigações próprios de sua peculiar condição de pessoa em desenvolvimento. Em comparação à Declaração de 24, o documento criado trinta e cinco anos depois, concebe a criança não mais como mero recipiente passivo, e passam a serem concebidos como sujeitos de direitos, capazes de gozar de direitos e liberdades" (RICHTER, Daniela; VIEIRA, Gustavo Oliveira; TERRA, Rosane Mariano da Rocha Barcelos. A Proteção Internacional da Infância e Juventude: Perspectivas, Contextos e Desafios. In PES, João Hélio Ferreira (coord). Direitos Humanos: Crianças e Adolescentes. Curitiba: Juruá, 2010. p. 50). 
lingüística da criança, bem como à conveniência da continuidade de sua educação.

Os Estados Partes que reconhecem ou permitem o sistema de adoção atentarão para o fato de que a consideração primordial seja o interesse maior da criança. Dessa forma, atentarão para que:

a) a adoção da criança seja autorizada apenas pelas autoridades competentes, as quais determinarão, consoante as leis e os procedimentos cabíveis e com base em todas as informações pertinentes e fidedignas, que a adoção é admissível em vista da situação jurídica da criança com relação a seus pais, parentes e representantes legais e que, caso solicitado, as pessoas interessadas tenham dado, com conhecimento de causa, seu consentimento à adoção, com base no assessoramento que possa ser necessário;

b) a adoção efetuada em outro país possa ser considerada como outro meio de cuidar da criança, no caso em que a mesma não possa ser colocada em um lar de adoção ou entregue a uma família adotiva ou não logre atendimento adequado em seu país de origem;

c) a criança adotada em outro país goze de salvaguardas e normas equivalentes às existentes em seu país de origem com relação à adoção;

d) todas as medidas apropriadas sejam adotadas, a fim de garantir que, em caso de adoção em outro país, a colocação não permita benefícios financeiros indevidos aos que dela participarem;

e) quando necessário, promover os objetivos do presente artigo mediante ajustes ou acordos bilaterais ou multilaterais, e envidarão esforços, nesse contexto, com vistas a assegurar que a colocação da criança em outro país seja levada a cabo por intermédio das autoridades ou organismos competentes.

Percebe-se, assim, que a preocupação central da Convenção sobre Direitos da Criança é garantir a proteção prioritária e integral dos interesses das pessoas em desenvolvimento, independentemente de se encontrarem em situação de risco.

Apesar de este tratado haver sido ratificado antes do advento da Reforma Constitucional, que incluiu o $\S 3^{\circ}$ no art. $5^{\circ}$ da $\mathrm{CF}$, é possível que ele seja recepcionado ${ }^{108}$ como norma constitucional, de acordo com o entendimento visto no item anterior.

\footnotetext{
${ }^{108}$ Nos dizeres de José Carlos Francisco: “Acerca da recepção, sabemos que se trata de princípio geral do Direito Constitucional (que independe de previsão expressa), segundo o qual as normas infraconstitucionais validamente editadas (sob o ângulo formal e material) na vigência de ordenamentos constitucionais anteriores continuam vigentes e eficazes em face de novos ordenamentos constitucionais (originários ou reformadores), bastando a compatibilidade material com as regras constitucionais supervenientes. É indiscutível que os atos normativos recepcionados somente podem ser alterados pela forma normativa exigida pelo novo ordenamento constitucional (ou seja, se uma lei ordinária foi validamente editada seguindo as previsões da Constituição pretérita, essa lei ordinária somente poderá ser modificada por lei complementar caso a nova Constituição disponha que o tema correspondente deva ser objeto de lei complementar), sob pena de inobservância da vontade do constituinte que passou a exigir nova modalidade normativa para a matéria. É verdade que a recepção convencional é vista envolvendo regras infraconstitucionais anteriores diante de novas ordens constitucionais (ou seja, a norma anterior tem forma infraconstitucional, e permanecerá como norma infraconstitucional, ainda que de competência ou hierarquia diversa), mas nada impede que o fenômeno da recepção seja aplicado em casos nos quais a ordem constitucional anterior permanece com força de regra constitucional em face do novo ordenamento constitucional (fenômeno denominado recepção material), ou em casos nos quais as regras constitucionais anteriores venham assumir status de normas infraconstitucionais (chamada de desconstitucionalização em sentido estrito). Admitimos que a doutrina e a jurisprudência aceitam a recepção material e a desconstitucionalização apenas mediante previsão
} 
Em outras palavras, todo e qualquer ato normativo infraconstitucional deverá respeitar a referida Convenção, sob pena de ser objeto de controle de convencionalidade.

Para o presente trabalho interessa, principalmente, a previsão normativa que trata da proteção do interesse da criança no desenrolar dos processos de adoção, conforme se verá adiante.

Ressalte-se, ademais, que, antes mesmo da adoção da Convenção acima mencionada, a Organização das Nações Unidas aprovou, em dezembro de 1986, a Declaração sobre os Princípios Sociais e Jurídicos relativos à Proteção e Bem-Estar das Crianças, com especial referência à adoção e colocação em lares substitutos. ${ }^{109}$ Esse documento, entretanto, ainda não foi ratificado pelo Brasil, muito embora suas normas tenham sido consagradas, em grande parte, no texto do Estatuto da Criança e do Adolescente.

A Declaração acima mencionada faz expressa menção à adoção internacional, como opção nos casos em que as demais modalidades de colocação da criança em família substituta forem inviáveis.

A adoção internacional foi regulamentada pela Convenção Relativa à Proteção das Crianças e à Cooperação em Matéria de Adoção Internacional, concluída em Haia em 29 de maio de 1993 e incorporada ao direito interno brasileiro em 21 de junho de 1999, pelo Decreto n. 3.087/99.

constitucional expressa, mas a controvérsia gerada pela Emenda Constitucional 45 em relação aos tratados sobre direitos humanos anteriores a 8 de dezembro de 2004 está mais próxima ou adequada à recepção convencional do que a esses dois outros instrumentos da hermenêutica constitucional, já que a recepção material e a desconstitucionalização pressupõem a ab-rogação da Constituição pretérita, o que não ocorre com os tratados internacionais sobre direitos humanos anteriores à Emenda 45 (os quais seguramente continuam vigendo)". (FRANCISCO, José Carlos. Bloco de Constitucionalidade e Recepção dos Tratados Internacionais. In TAVARES, André Ramos; LENZA, Pedro; ALARCÓN, Pietro de Jesús. Reforma do Judiciário analisada e comentada. São Paulo: Método, 2005. pp. 103-104).

${ }^{109}$ Para melhor compreensão do sistema de proteção dos direitos humanos das crianças e dos adolescentes, segue a transcrição de alguns artigos da Convenção: Artigo 2: "O bem estar da criança depende do bem estar da família". Artigo 3: "Como primeira prioridade, a criança deve receber cuidados de seus próprios pais". Artigo 4: "Quando os pais da criança não possam cuidar dela ou seus cuidados sejam impróprios, deve ser considerada a possibilidade de que os cuidados sejam encarregados a outros familiares dos pais da criança, outra família substitutiva - adotiva ou de guarda - ou caso seja necessário, uma instituição própria". Artigo 5: "Em todas as questões relativas ao cuidado de uma criança por pessoas que não sejam seus próprios pais, os interesses da criança, em particular sua necessidade de receber afeto e seu direito à segurança e aos cuidados contínuo, devem ser a consideração fundamental”. (grifos no original) 
Se a adoção é medida excepcional, pode-se afirmar que a adoção internacional ${ }^{110}$ é a exceção da exceção, podendo ser deferida somente nos casos em que forem esgotadas todas as possibilidades de inclusão da criança ou do adolescente em família de brasileiros ou estrangeiros residentes no país.

Para a grande maioria dos autores, a excepcionalidade da adoção internacional se justifica em razão das dificuldades de adaptação da criança a uma nova cultura, sendo salutar aos seus interesses que ela seja mantida em seu país de origem.

Por fim e não menos importante, deve ser mencionada a Convenção sobre a Eliminação de Todas as Formas de Discriminação Racial (1986), que tem como finalidade garantir a efetiva igualdade dos seres humanos, através da proibição da discriminação e da promoção de ações afirmativas.

Como bem lembrado por Flávia Piovesan, a igualdade e a discriminação pairam sob “o binômio inclusão-exclusão. Enquanto a igualdade pressupõe formas de inclusão social, a discriminação implica violenta exclusão e intolerância à diferença e diversidade". ${ }^{11}$

De acordo com esta Convenção,

\footnotetext{
${ }^{110}$ De acordo com os ensinamentos de Jacob Dolinger, a adoção internacional sofreu impulso com a segunda guerra mundial, sendo estimulada, posteriormente, pelas guerras e conflitos armados que atingiram alguns países da Ásia: "A tragédia da segunda conflagração mundial que sacrificou 50 milhões de vidas, que ocasionou miséria em grande parte da Europa e em alguns países da Ásia, deixando grande número de órfãos, estimulou a adoção internacional, pela qual pais, geralmente sem filhos, vivendo em países que não haviam sido afetados pela guerra, se interessaram por adotar crianças deixadas na orfandade e na penúria nos países europeus e asiáticos afetados pela guerra. A entrada da mulher para o mercado de trabalho sofisticado e para as carreiras profissionais, inclusive o magistério universitário, a liberação da mulher, os novos hábitos sexuais, o controle de natalidade, o crescente uso de anticoncepcionais, a legalização do aborto, a aceitação pela sociedade da mãe solteira, causaram o decréscimo do número de crianças disponíveis para a adoção nos países industrializados, o que afetou, com o tempo, não só os Estados Unidos, mas também os países da Europa Ocidental, já recuperados das conseqüências da guerra, levando em considerável número de famílias, especialmente aquelas em que a mulher se dedica a uma profissão, à procura de oportunidades para adotar uma criança de países onde, por não se praticar o controle de natalidade, e por haver elevado índice de pobreza, encontravam-se menores abandonados, entregues aos cuidados do Estado, ou menores cujos pais se dispunham a entregá-los para serem adotados. Nos decênios que vão de 1955 a 1975 esta foi a realidade asiática, principalmente na Coréia e, mais tarde, no Vietnã, onde se registrou grande número de adoções de crianças por famílias do Ocidente. Nos anos que se seguiram a 1975, e entrando no século XXI, este fenômeno também vem ocorrendo na América Latina, destacando-se o Brasil como país "exportador" de crianças adotadas por estrangeiros (...)" (DOLINGER, Jacob. Direito Internacional Privado. A Criança no Direito Internacional. Rio de Janeiro: Renovar, 2003. pp. 401-402).

${ }^{111}$ PIOVESAN, Flávia. Igualdade, diferença e direitos humanos: perspectivas global e regional. In LEITE, George Salomão; SARLET, Ingo Wolfgang (org.). Direitos Fundamentais e Estado Constitucional. Estudos em Homenagem a J.J. Gomes Canotilho. Coimbra: Coimbra Editora e Revista dos Tribunais, 2009. p. 305.
} 
A discriminação significa toda distinção, exclusão, restrição ou preferência que tenha por objeto ou resultado prejudicar ou anular o reconhecimento, gozo ou exercício, em igualdade de condições, dos direitos humanos e liberdades fundamentais (...). ${ }^{112}$

A análise desta Convenção Internacional será de extrema relevância para a adoção inter-racial, conforme se verá nos capítulos seguintes.

O panorama acima teve como finalidade sistematizar as normas de direito internacional aplicáveis ao presente trabalho, com a ressalva de que elas não esgotam o tema.

Os tratados de direitos humanos aqui mencionados dispuseram sobre diversos princípios voltados à proteção das crianças e dos adolescentes, posteriormente incorporados ao ordenamento jurídico interno, quer em razão da ratificação de seu texto pelo Brasil, quer em virtude de sua previsão expressa pela Constituição Federal (1988) e/ou pelo Estatuto da Criança e do Adolescente (1990).

${ }^{112}$ PIOVESAN, Flávia. Temas de Direitos Humanos. $4^{\mathrm{a}}$ ed. São Paulo: Saraiva, 2010. p. 243. 


\section{CAPÍTULO 3 \\ PROTEÇÃO DOS DIREITOS DAS CRIANÇAS NA ESFERA JURÍDICA NACIONAL ${ }^{113}$}

\subsection{Linhas Introdutórias}

Apesar de não haver muitos escritos a respeito do surgimento da família, não se duvida que o seu conceito sofreu profundas alterações nos últimos séculos.

Na Roma antiga, a palavra família denotava o conjunto de empregados de um senhor, sendo a submissão à autoridade traço marcante do seu conceito. Predominava na época o modelo patriarcal de família (família mais extensa).

Com a evolução do Direito Romano, a figura do patriarca foi perdendo aos poucos a sua força, cedendo espaço à autonomia da mulher e dos filhos. Neste período, o Direito Romano, proveniente do Estado, passa a conviver com o Direito Canônico, oriundo da Igreja.

Durante a Idade Média a família sofreu influência de três ramos diversos do Direito: o Direito Romano, o Direito Canônico e o Direito Bárbaro. Neste período, os laços de sangue e a coabitação eram os elementos constitutivos da família.

Uma análise do nosso Código Civil de 1916 e de algumas leis esparsas, dentre elas as que regulamentaram a união estável, demonstra que o conceito de família com base nos laços de sangue e na convivência prevaleceu, até bem pouco tempo, em nosso ordenamento jurídico.

Foi preciso uma mudança de paradigma, trazida, em especial, pela Constituição Federal, para que o conceito de família deixasse de lado seu perfil individualista e patriarcal.

113 Algumas das ideias defendidas neste Capítulo foram extraídas do trabalho de conclusão de curso apresentado na pós-graduação lato sensu em Direito Constitucional, intitulado "A inconstitucionalidade do processo judicial de adoção”, em 2006. 
Ressalte-se que alguns fatores, introduzidos pela nova ordem constitucional, foram fundamentais para a alteração da estrutura e da base familiar na sociedade contemporânea, conforme se percebe pela transcrição abaixo:

\begin{abstract}
(a) a estatização, ou seja, a crescente ingerência do Estado nas relações familiares; (b) a retração, no sentido da substituição do modelo de família extensa, do tipo patriarcal, pelo modelo de família nuclear, constituída do pai, da mãe e dos filhos menores; (c) a despatrimonialização, a saber, a mudança do caráter das relações patrimoniais da família, determinante da diminuição da importância do seu aspecto financeiro-econômico, dando maior ênfase aos aspectos existenciais; (d) a democratização, ou seja, a tendência em transformar a organização familiar num grupo societário do tipo igualitário, cujo processo acompanha a emancipação dos personagens familiares, como a esposa, a companheira e os filhos menores; (e) repersonalização e a desencarnação, representando a substituição do elemento carnal (ou biológico) pelo elemento psicológico (ou afetivo) e a conscientização de que, na formação da pessoa humana, deve-se atribuir maior valor à educação, ao afeto, à comunicação próxima do que à hereditariedade; (f) a dessacralização do casamento, no sentido de retirar os privilégios odiosos da instituição matrimonial, aproximando-a da realidade sociológica, daí a maior facilidade na dissolução da sociedade e do vínculo conjugal, a admissão do companheirismo como realidade jurídicofamiliar e a indistinção entre filhos matrimoniais e extramatrimoniais (...). ${ }^{114}$
\end{abstract}

De todos os fatores acima mencionados o mais relevante para o presente trabalho é aquele que, de alguma forma, influencia todos os demais: o da despatrimonialização. "Vivenciamos uma família matrizada na afetividade, que busca o seu espaço social, político e jurídico como legítimos instrumentos para a sua plena realização e satisfação pessoal". 115

Dessa maneira, a família ${ }^{116}$ hoje é formada por um grupo pequeno de pessoas (família nuclear), ligadas por laços de amor e de afeto, tendo como função primordial o pleno desenvolvimento de seus membros, em razão do reconhecimento do princípio da dignidade da pessoa humana.

114 GAMA, Guilherme Calmon Nogueira da. Princípios Constitucionais do Direito de Família. Guarda Compartilhada à Luz da Lei $n^{\circ}$ 11.698/08: família, criança, adolescente e idoso. São Paulo: Atlas, 2008. pp. 24-25.

${ }_{115}$ MADALENO, Rolf. Novas Perspectivas do Direito de Família. Porto Alegre: Livraria do Advogado, 2000. p. 19.

116 “Quando se pensa em direitos humanos fundamentais, o que primeiro vem à mente é o direito à vida. Mas não se pode pensar a vida humana sem pensar na família. Uma implica a outra, necessariamente, e por isso que o direito à vida implica o direito à família, fundando-o como o mais fundamental dos direitos familiais. Outros direitos humanos fundamentais também se ligam à família. A liberdade, a igualdade, a fraternidade, a solidariedade, a segurança, o trabalho, a saúde, a educação, enfim, a própria felicidade humana e tantos outros valores que são objeto de direitos humanos fundamentais e operacionais, todos eles se ligam ao direito à família e se realizam mais efetivamente no lar". (BARROS, Sérgio Resende de. Direitos Humanos $e$ Direito de Família. Palestra proferida em 29/08/2003, na XII Jornada de Direito de Família, realizada no Auditória de Assembleia Legislativa do Estado do Rio Grande do Sul, p. 2. Disponível em <www.srbarros.com.br〉. Acesso em 09/01/2013). 
Atenta a esta mudança de paradigma, a Constituição de 1988 previu que "A família, base da sociedade, tem especial proteção do Estado” (art. 226), reconhecendo que a garantia da entidade familiar é essencial para o desenvolvimento da personalidade individual e da coletividade.

Percebe-se, assim, que a família possui dupla função ${ }^{117}$ : a garantia do desenvolvimento saudável dos indivíduos que a compõem e da própria sociedade, por ser responsável pela socialização primária das crianças. Nesse sentido: ${ }^{118}$

\begin{abstract}
A família atual desempenha uma nítida função instrumental, servindo como meio para a realização pessoal dos seus componentes. Ela potencializa o pleno desenvolvimento educacional, sentimental, afetivo e profissional do indivíduo.

O desempenho da assistência moral e psicológica entre os membros da família, embora se possa contar com auxílio de médicos e psicólogos - como lembra Diogo Leite de Campos -, não deve ser transferido a esses profissionais, em sua totalidade, pois é uma função a ser desempenhada pela família.
\end{abstract}

A família contemporânea deixa de lado as funções religiosas, política, econômica e puramente assistencial, que lhe foram atribuídas anteriormente, para ser vista como o núcleo essencial da sociedade, responsável pelo livre desenvolvimento da personalidade de seus membros.

Neste contexto, pode-se afirmar ser a procriação uma função "meramente secundária, e não essencial à concepção da família". ${ }^{119}$ Entretanto, uma vez que a procriação se efetive, os filhos passam a ser o elemento central da família nuclear,

117 “A família, entendida como uma rede de cuidados e afetos, possui funções importantes para garantir o desenvolvimento da pessoa, como a função biológica, psicológica e social. Como função biológica, a família vela pelos primeiros cuidados e necessidades do bebê e da criança, permitindo seu desenvolvimento físico e cognitivo adequado. A função psicológica é central à existência da família por estabelecer interações afetivas ao longo da vida de um indivíduo, essenciais como suporte para seu desenvolvimento emocional e cognitivo. A função social decorre da transmissão dos padrões culturais, educação de valores e princípios de vida e de convivência. A família como instituição caracteriza-se por ser dinâmica e estruturalmente diversa, a qual, ao passo das transformações sociais, econômicas e políticas, vem adaptando-se e configurando-se entre distintos tipos e modelos, como os casais com ou sem filhos, a família monoparental formada por qualquer dos pais e o(s) filho(s), entre outras. Mesmo com a gama e pluralidade de formas e tipos com que a família em se manifestado atualmente, ela identifica-se como um fenômeno universal e histórico, que sustenta uma herança de gerações através do tempo e que permite, a partir de suas vivências e práticas internas, a construção e transmissão de saberes, hábitos, tradições e valores de vida" (ONU. Programa das Nações Unidas para o Desenvolvimento. Relatório de Desenvolvimento Humano Brasileiro 2009/2010. Brasília: PNUD, 2010. pp. 102-103).

118 OLIVEIRA, José Sebastião de. Fundamentos Constitucionais do Direito de Família. São Paulo: Revista dos Tribunais, 2002. pp. 269-271.

${ }^{119}$ OLIVEIRA, José Sebastião de. Fundamentos Constitucionais do Direito de Família. São Paulo: Revista dos Tribunais, 2002. p. 270. 
merecendo toda a proteção dos seus genitores, da sociedade e do Estado, nos termos do que dispõe o artigo 227, caput, da Constituição Federal:

É dever da família, da sociedade e do Estado assegurar à criança, ao adolescente e ao jovem, com absoluta prioridade, o direito à vida, à saúde, à alimentação, à educação, ao lazer, à profissionalização, à cultura, à dignidade, ao respeito, à liberdade e à convivência familiar e comunitária, além de colocá-los a salvo de toda forma de negligência, discriminação, exploração, violência, crueldade e opressão.

Percebe-se que o constituinte atribuiu às crianças e aos adolescentes os mesmos direitos previstos no artigo $5^{\circ}$ da Constituição Federal, que trata dos direitos fundamentais, além de estabelecer direitos específicos de sua condição de seres em desenvolvimento. As crianças e os adolescentes, por sua peculiar condição de seres em desenvolvimento, são merecedores de proteção geral e especial do sistema jurídico.

Em outras palavras, seguindo a tendência internacional, o constituinte brasileiro adotou a doutrina da proteção integral das crianças e dos adolescentes, posteriormente regulamentada pelo Estatuto da Criança e do Adolescente.

Uma das principais consequências desta teoria é o reconhecimento de que, por serem titulares de direitos (gerais, aplicáveis a todos os seres humanos, ou especiais), as crianças e os adolescentes merecem proteção contra toda e qualquer forma de violação, independentemente de estarem em situação de risco ou de abandono.

Frise-se que a análise histórica do sistema de proteção das crianças e dos adolescentes no Brasil deixa claro que a intervenção do Estado tinha como objeto, inicialmente, as crianças em situação irregular, através de sua institucionalização (Código de Menores-1979). Esta medida, porém, se mostrou absolutamente inadequada à proteção destes indivíduos, por ser incapaz de lhes propiciar a devida convivência familiar e o desenvolvimento saudável.

A adoção do princípio da dignidade da pessoa humana, como fundamento da República Federativa do Brasil, e da teoria da proteção integral das crianças e adolescentes, independentemente de estarem em situação de risco, trouxe consequências 
profundas para as relações familiares e para a interpretação dos próprios institutos jurídicos que a precederam.

Busca-se neste capítulo uma análise dos princípios que norteiam as relações familiares, com enfoque na proteção das crianças e adolescentes. Como não poderia deixar de ser, o primeiro princípio a ser estudado é o princípio da dignidade da pessoa humana, responsável pela alteração da própria estrutura familiar.

Conforme visto no capítulo anterior, diversos documentos internacionais se preocuparam com a proteção das crianças e adolescentes, tanto na esfera geral quanto na esfera específica. Estes tratados e convenções produziram efeitos no sistema jurídico interno, conforme se pode perceber pelo texto da Constituição Federal, do Estatuto da Criança e do Adolescente e do Código Civil de 2002, exemplificativamente.

Nos itens abaixo será feita uma abordagem dos princípios do Direito de Família mais relevantes, sob a óptica da proteção dos direitos das crianças e dos adolescentes.

\subsection{Princípio da dignidade da pessoa humana}

Conforme visto acima, é impossível estudar a concepção contemporânea da família e- mais especificamente- o sistema de proteção jurídica das crianças e dos adolescentes sem antes analisar o princípio da dignidade da pessoa humana, reconhecido expressamente pelas ordens jurídicas internacional e nacional.

Uma conceituação clara do que seja dignidade da pessoa humana ${ }^{120}$ se revela difícil e, muitas vezes, em nada satisfatória, como bem lembrado por Ingo Wolfgang Sarlet: ${ }^{121}$

\footnotetext{
120 "A dignidade da pessoa humana põe-se na lágrima vertida sem pressa, sem prece e, principalmente, sem busca de troca. Tal como se tem no pranto de Antígona, a dignidade não provoca, não intimida, não se amedronta. Tem ela a calma da justiça e o destemor da verdade. É por isso que Antígona representa a dignidade do homem para além da vida, a que se acha sem rebuços nos momentos extremos da experiência humana e nos quais desimporta a conduta do outro ou a correspondência de seu sentimento, de sua fé ou de seu pensamento em relação àquele que se conduz dignamente. Dignidade é alteridade na projeção sociopolítica tanto quanto é subjetividade na ação individual" (ROCHA, Carmen Lúcia Antunes. O Princípio da Dignidade da Pessoa Humana e a Exclusão Social. Fortaleza, Revista do Instituto Brasileiro de Direitos Humanos, ano 2, vol. 2, número 2, p.49, 2001).

${ }^{121}$ SARLET, Ingo Wolfgang. Dignidade da Pessoa Humana e Direitos Fundamentais na Constituição Federal de 1988. $4^{\text {a }}$ ed. Porto Alegre: Livraria do Advogado, 2006. pp. 57-58.
} 
Reduzir a uma fórmula abstrata e genérica tudo aquilo que constitui o conteúdo da dignidade da pessoa humana, em outras palavras, a definição de seu âmbito de proteção ou de incidência (em se considerando a sua condição de norma jurídica), não parece ser possível, o que, por sua vez, não significa que não se possa ou deva buscar uma definição, que, todavia, acabará alcançando pleno sentido e operacionalidade em face do caso concreto. Com efeito, para além dos aspectos ventilados, a busca de uma definição necessariamente aberta, mas minimamente objetiva impõe-se justamente em face da exigência de certo grau de segurança e estabilidade jurídica bem como para evitar que dignidade continue a justificar o seu contrário.

A dificuldade de se definir a dignidade da pessoa humana, entretanto, não pode servir de muleta para a sua aplicação irrestrita e sem critérios, sob pena de se ocasionar o efeito inverso do pretendido pelo legislador, a saber, a banalização do seu conteúdo e a não proteção da pessoa humana. ${ }^{122}$

Muitos juristas sustentam que o ponto de partida para se conceituar a dignidade da pessoa humana deve ser, necessariamente, os ensinamentos de Kant. Entretanto, antes mesmo do pensamento kantiano, já se falava em dignidade, ainda que com fundamentos diversos dos adotados pelo filósofo.

Para se compreender o conceito do princípio aqui estudado, faz-se imprescindível analisar a definição de pessoa, elemento central do conceito de dignidade (em todas as suas concepções).

De acordo com os ensinamentos de Fábio Kander Comparato ${ }^{123}$, o conceito de pessoa sofreu constantes alterações nós últimos séculos passando por, pelo menos, cinco

\footnotetext{
${ }^{122}$ Nesse sentido, conferir Iñigo de Miguel Beriain: “(...) lo que ya no está cierto es que todos los que apelan a la dignidad humana como argumento en el que apoyar sus pretensiones sepan verdaderamente de qué están hablando. Y no nos referimos aquí exclusivamente a quienes, alejados de las discusiones filosóficas académicas, apenas tienen la oportunidad de entender todos los significados de aquello que invocan. Son, por el contrario, múltiples los ejemplos contradicciones, incoherencias e incluso puros dislates en la literatura específicamente dedicada a la materia. Tanto es así que no es exagerado afirmar que, a pesar de su enorme importancia en el pensamiento filosófico y jurídico contemporáneo, el concepto de dignidad humana sigue sin ser adecuadamente formulado, ni aclaradas todas las dudas que su propia definición suscita entre aquellos que deben trabajar para su defensa. La consecuencia inmediata de este galimatías es que demasiado frecuentemente realizamos un uso del todo inapropiado del concepto, empleando la dignidad humana como último y aplastante recurso para imponer nuestras ideas o rechazar las de aquellos otros que no las comparten. Se llega a dar, por consiguiente, la humillante paradoja de que, en según que discusiones, personas que sostienen tesis diametralmente opuestas apelan a la misma causa: la defensa de la dignidad humana" (BERIAIN, Miguel. Es digno ser un ser que no es autónomo? Reflexiones acerca del concepto kantiano de dignidad humana. In . Estudios en Homenaje al Profesor Gregorio Peces-Barba. Madrid: Dykinson, 2008. Vol III, pp. 415-416).

${ }^{123}$ COMPARATO, Fábio Konder. A Afirmação Histórica dos Direitos Humanos. $4^{\mathrm{a}}$ ed. São Paulo: Saraiva, 2005. pp. 11-36.
} 
estágios evolutivos, a saber: 1) a vinculação do conceito de pessoa a preceitos religiosos (Deus é a imagem de pessoa para todos os seres humanos); ${ }^{124}$ 2) o entendimento de que a pessoa não é apenas uma exterioridade, mas um conjunto de substância e espírito; 3) a visão da pessoa como ser racional, capaz de autodeterminação; 4) o reconhecimento de que a pessoa, em virtude da razão, é o único ser vivo capaz de criar normas valorativas e se submeter a elas e, finalmente, 5) a compreensão do ser em constante evolução. Estes estágios evolutivos correspondem às três perspectivas que justificaram a excelência do homem no mundo moderno: a religiosa, a filosófica e a científica.

O pensamento kantiano se desenvolveu durante o estágio evolutivo em que a pessoa é vista como ser racional e autônomo, conforme se percebe pela transcrição a seguir:

\begin{abstract}
O homem, e de uma maneira geral, todo ser racional, existe como um fim em si mesmo, não só como meio para o uso arbitrário desta ou daquela vontade. Pelo contrário, em todas as suas acções, tanto nas que se dirigem a ele mesmo como nas que se dirigem a outros seres racionais, ele tem sempre de ser considerado simultaneamente como fim.

(...) Os seres cuja existência depende, não em verdade da nossa vontade, mas da natureza, têm, contudo, se são seres irracionais, apenas um valor relativo como meios e por isso se chama coisas, ao passo que os seres racionais se chamam pessoas, porque a sua natureza os distingue já como fins em si mesmos, quer dizer, como algo que não pode ser empregado como simples meio e que, por conseguinte, limita nessa medida todo o arbítrio. ${ }^{125}$
\end{abstract}

Sendo assim, para Kant, a racionalidade ${ }^{126}$ e a autonomia são as características que atribuem ao homem a titularidade da dignidade. Nas palavras do filósofo, “(...) no reino

\footnotetext{
${ }^{124}$ Conferir PICO DELLA MIRÀNDOLA, Giovanni. Discurso sobre a dignidade do homem. Tradução de Maria de Lurdes Sirgado Ganho. Lisboa: Edições 70, 2001.

${ }^{125}$ KANT, Immanuel. Fundamentação da Metafísica dos Costumes. Rio de Janeiro: Edições 70, 1991. p. 68. ${ }^{126}$ De acordo os ensinamentos de Rodrigo da Cunha Pereira, "A dignidade da pessoa humana é, e sempre será, um valor idêntico que todo ser humano tem porque é racional. Não há relatividade da capacidade que permita eliminar a razão de um ser humano; é por isso que, do ponto de vista ético, no Direito todo ser humano tem o mesmo valor. Se a dignidade é hoje um princípio constitucional, isso é o resultado de uma conquista histórica. É o reconhecimento de que não importa quais sejam as circunstâncias ou qual o regime político, todo ser humano deve ter reconhecido pelo Estado o seu valor como pessoa e a garantia, na prática, de uma personalidade que não deve ser menosprezada ou desdenhada por nenhum poder. Exigir, por meio de preceito constitucional, que o Estado reconheça a dignidade da pessoa humana é exigir que ele garanta a todos direitos que podem ser considerados válidos para um ser humano capaz de compreender o que é o bem" (PEREIRA, Rodrigo da Cunha. Princípios Fundamentais Norteadores do Direito de Família. Belo Horizonte: Del Rey, 2006. p. 98).
} 
dos fins tudo tem um preço ou uma dignidade. (...) quando uma coisa está acima de todo o preço e, portanto não permite equivalente, então tem ela dignidade". ${ }^{127}$

Esta concepção racional da dignidade da pessoa humana foi adotada pela Declaração Universal dos Direitos Humanos (1948), que dispõe, em seu artigo $1^{\circ}$, que “Todos os seres humanos nascem livres e iguais em dignidade e direitos. São dotados de razão e consciência e devem agir em relação uns aos outros com espírito de fraternidade”.

O direito contemporâneo passou a ver na dignidade da pessoa humana o fundamento dos direitos- e dentre eles os direitos humanos-, abandonando as teorias que deitavam as suas raízes em concepções religiosas ou metafísicas. Nesse sentido ${ }^{128}$ :

\begin{abstract}
Uma das tendências marcantes do pensamento moderno é a convicção generalizada de que o verdadeiro fundamento de validade- do direito em geral e dos direitos humanos em particular - já não deve ser procurado na esfera sobrenatural da revelação religiosa, nem tampouco numa abstração metafísica - a natureza - como essência imutável de todos os entes no mundo. Se o direito é uma criação humana, o seu valor deriva, justamente, daquele que o criou. O que significa que esse fundamento não é outro, senão o próprio homem, considerado em sua dignidade substancial de pessoa, diante da qual as especificações individuais e grupais são sempre secundárias.
\end{abstract}

A Constituição Federal de 1988, seguindo a linha das Constituições Alemã (1949), Portuguesa (1976) e Espanhola (1978), estabeleceu que a dignidade da pessoa humana é um dos fundamentos da nossa República.

Não restam dúvidas, assim, que a dignidade da pessoa humana como princípio constitucional é uma conquista histórica. A preocupação com o ser humano, como sujeito de direitos, tornou-se patente com a eclosão da Segunda Guerra Mundial e as atrocidades praticadas pelo regime nazista, ${ }^{129}$ sendo claro que a primeira Constituição a prever o princípio da dignidade da pessoa humana, de forma expressa, foi a Constituição Alemã. ${ }^{130}$

\footnotetext{
${ }^{127}$ KANT, Immanuel. Fundamentação da Metafísica dos Costumes. Rio de Janeiro: Edições 70, 1991. p. $75-$ 77.

${ }^{128}$ COMPARATO, Fábio Konder. Fundamentos dos Direitos Humanos. São Paulo: Instituto de Estudos Avançados da Universidade de São Paulo, 1997, p. 7. Texto disponível em <www.iea.usp.br/artigos>. $19 / 03 / 2012$.

${ }^{129}$ De acordo com a lição de Flávia Piovesan, "Esta é a vertente contemporânea do Direito do Pós-Guerra, tanto no âmbito internacional, como no âmbito local. Ao final da Segunda Guerra-Mundial, emerge o repúdio à ideia de um ordenamento jurídico divorciado de valores éticos. Intenta-se a reaproximação da ética e do Direito e, neste esforço, surge a força normativa dos princípios, especialmente, do princípio da dignidade humana. Há um reencontro com o pensamento kantiano, com as ideias de moralidade, dignidade, Direito
} 
Frise-se que a positivação da dignidade da pessoa humana trouxe consequências importantes para a interpretação e a aplicação das normas jurídicas, a saber:

\begin{abstract}
(...) i) a afirmação solene de que cada pessoa humana constitui um valor eminente (de onde resulta um equivalente e imediato reconhecimento de uma igualdade de princípio entre todos os seres humanos); ii) o estabelecimento de um vínculo positivo entre a decisão político-jurídica e o plano moral (onde foi colhido esse valor); iii) a fundação da comunidade nesta representação (daí lhe advindo a feição de elemento "de base", em especial da ordem constitucional); iv) a declaração de que as normas e instituições estão a serviço do sentido a adscrever a esse elemento de base (trata-se de uma actualização do velho brocardo hominum causa omne ius constitutum est); v) a observação de que o conteúdo da dignidade da pessoa humana é dado, em primeira linha, pelas normas de direitos fundamentais e pelas demais normas e instituições que visem assegurar as condições mínimas de realização do ser humano (num fenómeno que se pode facilmente representar e descrever como "esclarecimento recíproco"). ${ }^{131}$
\end{abstract}

Por fim, cumpre não olvidar que o princípio da dignidade da pessoa humana possui um caráter dúplice. Ele abarca não apenas a garantia de que a pessoa não será alvo de ofensas, como também se encarrega da proteção do desenvolvimento da personalidade do indivíduo. Nesse sentido: ${ }^{132}$

A dignidade humana consiste não apenas na garantia negativa de que a pessoa não será alvo de ofensas ou humilhações, mas também agrega a afirmação positiva do pleno desenvolvimento da personalidade de cada indivíduo. O pleno desenvolvimento da personalidade pressupõe, por sua vez, de um lado, o reconhecimento da total autodisponibilidade, sem interferências ou impedimentos externos, das possíveis atuações próprias de cada homem, de outro, a autodeterminação que surge da livre projeção histórica da razão humana, antes que de uma predeterminação dada pela natureza.

É justamente este caráter dúplice que interessa ao presente trabalho, por representar o ideal de prevenção e promoção dos direitos humanos fundamentais.

Com fundamento nas características até aqui expostas, Ingo Wolfgang Sarlet ${ }^{133}$ conceitua a dignidade da pessoa humana como

cosmopolita e paz perpétua" (PIOVESAN, Flávia. Direitos Humanos, o Princípio da Dignidade Humana e a Constituição Brasileira de 1988. In Revista dos Tribunais, vol. 94, p. 52, mar./2005).

${ }^{130}$ Artigo $1^{\circ}$ da Constituição Alemã: "A dignidade do homem é inviolável. Respeitá-la e protegê-la é dever de todos os Poderes do Estado".

${ }^{131}$ ALEXANDRINO, José de Melo. Os direitos das crianças: linhas para uma construção unitária. In TEIXEIRA, Ana Carolina Brochado et al (coords.). Problemas da Família no Direito. Belo Horizonte: Del Rey, 2012. pp.201-202.

${ }^{132}$ TAVARES, André Ramos. Princípio da Dignidade da Pessoa Humana. In Luiz Alberto David Araújo; SEGALLA, José Roberto Martins (coords.). 15 anos da Constituição Federal em busca da efetividade. Bauru: EDITE, 2003, p. 20.

${ }^{133}$ SARLET, Ingo Wolfgang. Dignidade da Pessoa Humana e Direitos Fundamentais na Constituição Federal de 1988. $4^{\text {a }}$ ed. Porto Alegre: Livraria do Advogado, 2006. p. 60. 


\begin{abstract}
A qualidade intrínseca e distintiva reconhecida em cada ser humano que o faz merecedor do mesmo respeito e consideração por parte do Estado e da comunidade, implicando, neste sentido, um complexo de direitos e deveres fundamentais que assegurem a pessoa tanto contra todo e qualquer ato de cunho degradante e desumano, como venham a lhe garantir as condições existenciais mínimas para uma vida saudável, além de propiciar e promover sua participação ativa e co-responsável nos destinos da própria existência e da vida em comunhão com os demais seres humanos.
\end{abstract}

Neste contexto, pode-se afirmar que a família é a instituição que proporciona o pleno desenvolvimento do ser humano, devendo os seus integrantes ser tratados com respeito e dignidade.

A Constituição Federal de 1988 representou importante avanço para o Direito de Família, ao adotar normas com conteúdo ético. Exemplos desta mudança são: a aceitação da união estável como modalidade de entidade familiar, a igualdade entre marido e mulher, a proibição de se estabelecer diferença entre os filhos havidos fora ou dentro do casamento, o reconhecimento da necessidade de o Estado intervir no planejamento familiar etc.

Feitas estas considerações, torna-se possível a análise dos princípios específicos norteadores do Direito de Família.

\title{
3.3. Princípio do melhor interesse da criança
}

A adoção da doutrina da proteção integral trouxe como consequência a imposição de diversos princípios voltados à proteção dos direitos das crianças e dos adolescentes, dentre eles o princípio do melhor interesse da criança. ${ }^{134}$

Apesar de não previsto de forma explícita na Constituição, este princípio é um desdobramento lógico do princípio da dignidade da pessoa humana, que, aplicado no âmbito do Direito de Família, tem como principal consequência a valorização de cada

\footnotetext{
134 “A origem da noção da noção do princípio do melhor interesse da criança é apontada como sendo a do instituto do parens patriae do direito inglês- na tradição anglo-saxã- em que a Coroa inglesa tinha a prerrogativa de tutelar aqueles sem condições de se proteger sozinhos, ou seja, os incapazes de fato que, desse modo, teriam sua pessoa e seu patrimônio- seus bens- sob a responsabilidade da Coroa, sendo que a partir do século XIV tal responsabilidade passou a ser do Chanceler (...)" (GAMA, Guilherme Calmon Nogueira da. Cuidado e Planejamento Familiar. In PEREIRA, Tânia da Silva; OLIVEIRA, Guilherme de. Cuidado e Vulnerabilidade. São Paulo: Atlas, 2009. p. 241).
} 
membro da entidade familiar e o reconhecimento de que a criança e o adolescente, por sua condição de vulnerabilidade, ${ }^{135}$ merecem especial proteção da família, do Estado e da sociedade. Nesse sentido: ${ }^{136}$

O princípio do melhor interesse da criança - considere-se, também, do adolescente, por força do próprio dispositivo constitucional- representa importante mudança de eixo nas relações paterno-materno-filiais, em que o filho deixa de ser considerado objeto para ser alçado- com absoluta justiça, ainda que tardiamente- a sujeito de direito, ou seja, à pessoa humana merecedora de tutela do ordenamento jurídico, mas com absoluta prioridade comparativamente aos demais integrantes da família de que ele participa. Cuida-se, assim, de reparar um grave equívoco na história da civilização humana em que o menor era relegado a plano inferior, ao não titularizar ou exercer qualquer função na família e na sociedade, ao menos para o Direito. Como pessoas humanas em processo físico e psíquico de desenvolvimento, a criança e o adolescente são portadores de condição peculiar a merecer tratamento diferenciado das outras pessoas.

O desdobramento acima mencionado, entretanto, não é capaz de solucionar o problema da imprecisão do conteúdo do princípio do melhor interesse da criança e do adolescente. Afinal, a definição do que seja melhor para o menor varia de acordo com o caso concreto e com o contexto social e cultural em que a criança está inserida, dependendo sempre da análise da situação real.

Dessa maneira, para se compreender a extensão do princípio do melhor interesse da criança e do adolescente, vale a pena analisar a interpretação a ele conferida pelo Poder Judiciário, quando da análise de casos concretos, em especial nas demandas que envolvem a fixação de custódia, tendo em mente que o melhor interesse está sempre ligado à formação da personalidade dos indivíduos em desenvolvimento. ${ }^{137}$

\footnotetext{
135 "É esta vulnerabilidade que é a noção distintiva fundamental, sob a ótica do estabelecimento de um sistema especial de proteção, eis que distingue crianças e adolescentes de outros grupos de seres humanos simplesmente diversos da noção de homo medio. É ela, outrossim, que autoriza a aparente quebra do princípio da igualdade: porque são portadores de uma desigualdade inerente, intrínseca, o ordenamento confere-lhes tratamento mais abrangente como forma de equilibrar a desigualdade de fato e atingir a igualdade jurídica material e não meramente formal" (PEREIRA, Rodrigo da Cunha. Princípios Fundamentais Norteadores do Direito de Família. Belo Horizonte: Del Rey, 2006. p. 132).

${ }^{136}$ GAMA, Guilherme Calmon Nogueira da. Cuidado e Planejamento Familiar. In PEREIRA, Tânia da Silva; OLIVEIRA, Guilherme de. Cuidado e Vulnerabilidade. São Paulo: Atlas, 2009. pp. 240-241.

137 "De fato, o interesse a ser resguardado nas hipóteses de disputa de guarda, ou de qualquer outra forma de custódia, é o interesse da criança, superior entre eventuais outros interesses em jogo. Por melhor interesse da criança, no entanto, não deve ser pensado apenas um simplório interesse egoístico desse ser que ainda se encontra em estágio formativo. O interesse da criança é o interesse mediato, é aquele interesse em ter a sua personalidade resguardada e bem formada; e não, ao contrário, o interesse imediato, que possa ter se forjadoou que possa ter sido forjado- em seu âmago, dirigindo-se aleatoriamente nesta ou naquela direção. Pode-se afirmar, assim, que o que se visa satisfazer é o desejo da criança enquanto sujeito de direitos, e não a mera satisfação dos objetos de desejo dessa mesma criança (...). Nesse sentido, o interesse da criança pode ser visto como um desejo da sociedade de que a criança seja bem formada" (HIRONAKA, Giselda; MONACO,
} 
Diferentemente do que ocorria em passado próximo, em que a guarda dos filhos era concedida, preferencialmente, em favor da mãe (Tender Years Doctrine), em razão de sua maior disponibilidade para prestar o dever de cuidado e assistência, ${ }^{138}$ hoje, as decisões judiciais levam em consideração o melhor interesse do menor (Tiebreaker). ${ }^{139}$

Nesse sentido, vêm sustentando os nossos Tribunais que em caso "de disputa entre cônjuges separados, não se atende à vontade dos pais, mas à convivência e bem estar dos filhos, de modo a deferir a guarda a quem, realmente, tenha melhores condições de exercêla”. (TJMG, AC 68.891, Rel. Dês. Vaz de Melo. Julgado em 17/04/1986).

Ressalte-se que esta mudança de posicionamento teve como causa as mudanças operadas na estrutura familiar e a conquista de espaço no mercado de trabalho pelas mulheres, não sendo mais possível afirmar que a maternidade, por si só, confere às genitoras melhores condições para exercer a guarda e o cuidado dos filhos.

Em consonância com a posição que já vinha sendo adotada pela jurisprudência e com a finalidade de emprestar mais objetividade ao princípio aqui analisado, o Código Civil de 2002 estabeleceu, em seu artigo 1583, $\S 2^{\circ}$, como fatores preponderantes para se aferir o melhor interesse da criança e do adolescente a afetividade, a saúde, a segurança e a educação.

Gustavo Ferraz de Campos. Síndrome de Alienação Parental. In TEIXEIRA, Ana Carolina Brochado et al (coords.). Problemas da Família no Direito. Belo Horizonte: Del Rey, 2012. p. 239).

${ }^{138}$ Nesse sentido, conferir MADALENO, Rolf Hanssen. A guarda compartilhada pela ótica dos direitos fundamentais. In WELTER, Belmiro Pedro; MADALENO, Pedro Hanssen. Direitos Fundamentais do Direito de Família. Porto Alegre: Livraria do Advogado, 2004. pp. 344-345. “(...) prevalecia a guarda materna nas relações conjugais desfeitas pela crença de ser a mãe a natural guardiã da prole, por dispor do dom de quem abriga o filho desde a sua concepção, e do tempo livre para se dedicar às tarefas domésticas, em contraponto ao trabalho externo, e a menor dedicação do pai”.

139 "Nos Estados Unidos (...) a partir do julgamento ocorrido em 1813, na Corte de Pensilvânia, foi reconhecido o melhor interesse da criança para resolver disputas judiciais relacionadas à guarda jurídica do filho no período pós-dissolução da sociedade conjugal dos pais. O julgamento ensejou a construção jurídica da teoria que passou a prevalecer e tornou-se conhecida como Tender Years Doctrine consistente no reconhecimento de que a criança- devido à pouca idade- necessitava dos cuidados maternos, o que representou o critério da 'presunção de preferência materna', posteriormente alterado para a orientação conhecida como tiebreaker, ou seja, a teoria que recomenda que não há preferência maternal, mas sim a determinação de que todos os elementos devem ser considerados dentro do princípio da neutralidade quanto ao melhor interesse da criança" (GAMA, Guilherme Calmon Nogueira da. Cuidado e Planejamento Familiar. In PEREIRA, Tânia da Silva; OLIVEIRA, Guilherme de. Cuidado e Vulnerabilidade. São Paulo: Atlas, 2009. p. 241). 
Os fatores mencionados expressamente pelo legislador ordinário, por óbvio, não esgotam todas as circunstâncias que devem ser observadas pelo Poder Judiciário no momento da solução de conflitos que envolvem crianças e adolescentes. Entretanto, não restam dúvidas de que estes elementos estão inseridos no conteúdo do que se convencionou chamar de dever de cuidado, visto como uma "forma responsável de se relacionar". 140

Dessa maneira, para que os interesses das crianças e dos adolescentes sejam protegidos, de forma ampla e eficaz, é preciso que sejam resguardadas sua saúde, segurança e educação, em ambiente familiar permeado pelo afeto e no qual se busque garantir a preservação dos referenciais destas pessoas em desenvolvimento.

De acordo com Rodrigo da Cunha Pereira, ${ }^{141}$ o respeito ao princípio do melhor interesse da criança pressupõe a manutenção de três referenciais de continuidade, quais sejam: (i) a continuidade da afetividade; (ii) a continuidade social, que indica a necessidade de preservação do ambiente e do relacionamento social, até então vivido pela criança e (iii) a continuidade espacial, determinando que o espaço da criança deve ser preservado, porque a personalidade do menor é construída dentro de um certo espaço.

Frise-se que estes referenciais de continuidade são levados em consideração nas ações de fixação de guarda e nos processos de adoção, tendendo o magistrado a manter a guarda com a pessoa que já tinha o menor sob seus cuidados, dando prevalência à manutenção do ambiente familiar, cultural e social estabelecido.

Isto porque, as mudanças na vida familiar das crianças e dos adolescentes trazem influência negativa na formação de sua personalidade, como bem lembrado por Silvana Maria Carbonera:

A continuidade na vida da criança é um aspecto a ser considerado. Diante de uma ruptura, o filho terá que aprender a lidar com a sua nova realidade, elaborando o luto pela perda da antiga vida familiar. Este é um momento psicológico delicado, onde terá de ser elaborada a reorganização da vida familiar.

\footnotetext{
${ }^{140}$ OLIVEIRA e TELLES, Marília Campos; COLTRO, Antônio Carlos Mathias. Cuidando do cuidado. In PEREIRA, Tânia da Silva; OLIVEIRA, Guilherme de. Cuidado e Vulnerabilidade. São Paulo: Atlas, 2009. p. 62.

${ }^{141}$ PEREIRA, Rodrigo da Cunha. Princípios Fundamentais Norteadores do Direito de Família. Belo Horizonte: Del Rey, 2006. p. 137.
} 
Uma vez tendo conseguido se adaptar a uma nova situação familiar, onde recebe satisfatoriamente o necessário para o seu desenvolvimento, a alteração da guarda e de seu ambiente quotidiano poderá implicar numa perda desnecessária de referencial, desatendendo seu interesse muitas vezes em benefício do interesse do genitor. Assim, o menor deve ser mantido onde está, desde que aí se encontre bem. A troca do meio ambiente deve ser evitada o quanto possível, para não causar prejuízo psíquico à criança. ${ }^{142}$ (grifos da autora)

Percebe-se, assim, que o resguardo do melhor interesse do menor não está relacionado com a capacidade financeira do guardião, do visitante ou do interessado na adoção, personagens mais corriqueiros na vida forense. Muito pelo contrário, zelar pelo interesse do menor significa proporcionar a ele um ambiente familiar saudável e equilibrado, propício ao desenvolvimento físico, psíquico, emocional e espiritual da criança e do adolescente.

\subsection{Princípio da Convivência Familiar}

Os princípios do melhor interesse da criança e do adolescente e da convivência familiar estão intimamente relacionados, sendo que a análise de ambos de forma separada se deu apenas por questões metodológicas.

Como já afirmado anteriormente, é no seio da família ${ }^{143}$ que o indivíduo colhe os subsídios para a formação de sua personalidade. Em virtude desta circunstância, é importante que o Estado e a sociedade se valham de todos os meios eficazes para propiciar a convivência familiar sadia a todas as crianças e adolescentes.

${ }^{142}$ CARBONERA, Silvana Maria. Guarda de filhos na família constitucionalizada. Porto Alegre: Sergio Antonio Fabris Editor, 2000. p. 132.

${ }^{143 ،(. . .) ~ n o s ~ s e u s ~ v a ́ r i o s ~ a s p e c t o s-~ o ~ f i ́ s i c o, ~ o ~ s o c i a l, ~ o ~ e c o n o ̂ m i c o ~ e ~ o ~ p s i ́ q u i c o-~ o ~ d i r e i t o ~ a o ~ l a r ~ s e ~ a s s o c i a ~ a o s ~}$ demais direitos humanos operacionais da família, os quais se escalonam em diversos graus de fundamentalidade. Primeiramente, o direito ao lar associa-se aos direitos que garantem a infraestrutura física da entidade familiar, como o direito à moradia e ao bem de família. Mas também se associa aos direitos que protegem a estrutura social da família, como o direito a contrair o casamento ou a permanecer na união estável, o direito à igualdade entre marido e mulher, o direito ao planejamento familiar, o direito ao poder familiar, o direito à obediência filial, o direito à paternidade, à maternidade, à adoção, à assistência familiar e outros. Também o direito ao lar está ligado aos direitos que zelam pela estrutura econômica da família, como o direito ao condomínio patrimonial, o direito à gratuidade do casamento, o direito à herança e sucessão, a alimentos e pensões. Enfim, está ligado aos direitos que dizem com a superestrutura cultural e psíquica da entidade familiar, tais como o direito à vivência doméstica e à convivência familiar, o direito ao apoio da família à saúde, educação, edificação e solidificação da pessoa humana, o direito ao reconhecimento da paternidade, maternidade ou da filiação, o direito ao parentesco e à afinidade, assim como o direito ao respeito e à amizade entre os familiares" (BARROS, Sérgio Resende de. Direitos Humanos e Direito de Família. Palestra proferida em 29/08/2003, na XII Jornada de Direito de Família, realizada no Auditório da Assembleia Legislativa do Estado do Rio Grande do Sul, pp. 2-3. Disponível em <www.srbarros.com.br>. Acesso em 09/01/2013). 
Vale ressaltar que quando se fala em convivência familiar, tem-se em mente não somente o convívio no seio da família natural, como também a colocação em família substituta. Afinal, de nada adiantaria conferir aos menores a manutenção da convivência no seio de sua família natural, se esta fosse incapaz de zelar pelos seus interesses e pelo pleno desenvolvimento de sua personalidade.

A Lei n. 12.010/2009 (Lei Nacional de Adoção), entretanto, teve como principal objetivo resguardar a convivência das crianças e adolescentes no seio da família natural, encarando a adoção como medida residual e excepcional. Nesse sentido: ${ }^{144}$

Ao lado da tutela e da guarda, a adoção é uma espécie de medida protetiva de colocação em família substituta. Contudo, diferentemente das primeiras, estabelece o parentesco civil entre o adotante e o adotado. De acordo com a Lei Nacional de Adoção, trata-se de medida excepcional, à qual se deve recorrer somente quando esgotadas todas as possibilidades de manutenção da criança ou do adolescente na família natural ou extensa. É excepcional porque a adoção é irrevogável, isto é, produz efeitos definitivamente. Impossibilita, portanto, a retomada do poder familiar pelos pais biológicos.

Sendo assim, a adoção só será possível quando for inviável a reinserção da criança no seio de sua família natural, sendo a guarda conferida à família extensa medida preferencial nos casos de perda do poder familiar.

Cabe lembrar, ademais, que o princípio da convivência familiar serve como base para a guarda compartilhada, introduzida pela Lei n. 11.698/2008, que deu nova redação aos artigos 1.583 e 1.584 do Código Civil, que assim dispõem, respectivamente:

Artigo 1.583. A guarda será unilateral ou compartilhada.

$\S 1^{\circ}$ Compreende-se por guarda unilateral a atribuída a um só dos genitores ou a alguém que o substitua (art. 1.584, $\S 5^{\circ}$ ) e, por guarda compartilhada a responsabilização conjunta e o exercício de direitos e deveres do pai e da mãe que não vivam sob o mesmo teto, concernentes ao poder familiar dos filhos comuns.

$\S 2^{\circ}$ A guarda unilateral será atribuída ao genitor que revele melhores condições para exercê-la e, objetivamente, mais aptidão para propiciar aos filhos os seguintes fatores:

I - afeto nas relações com o genitor e com o grupo familiar;

II - saúde e segurança;

III - educação.

$\S 3^{\circ}$ A guarda unilateral obriga o pai ou a mãe que não a detenha a supervisionar os interesses dos filhos.

144 TAKAHASHI, Estela Mayumi. A adoção no Brasil. In SILVA, Regina Beatriz Tavares da; CAMARGO NETO, Theodureto de Almeida Camargo. Grandes Temas de Direito de Família e das Sucessões. São Paulo: Saraiva, 2011.p. 297. 
Art. 1.584. A guarda, unilateral ou compartilhada, poderá ser:

I - requerida, por consenso, pelo pai e pela mãe, ou por qualquer deles, em ação autônoma de separação, de divórcio, de dissolução de união estável ou em medida cautelar; II - decretada pelo juiz, em atenção a necessidades específicas do filho, ou em razão da distribuição de tempo necessário ao convívio deste com o pai e com a mãe.

$\S 1^{\circ} \mathrm{Na}$ audiência de conciliação, o juiz informará ao pai e à mãe o significado da guarda compartilhada, a sua importância, a similitude de deveres e direitos atribuídos aos genitores e as sanções pelo descumprimento de suas cláusulas.

$\S 2^{\circ}$ Quando não houver acordo entre a mãe e o pai quanto à guarda do filho, será aplicada, sempre que possível, a guarda compartilhada.

$\S 3^{\circ}$ Para estabelecer as atribuições do pai e da mãe e os períodos de convivência sob guarda compartilhada, o juiz, de ofício ou a requerimento do Ministério Público, poderá basear-se em orientação técnico-profissional ou de equipe interdisciplinar.

$\S 4^{\circ}$ A alteração não autorizada ou o descumprimento imotivado de cláusula de guarda, unilateral ou compartilhada, poderá implicar a redução de prerrogativas atribuídas ao seu detentor, inclusive quanto ao número de horas de convivência com o filho.

$\S 5^{\circ}$ Se o juiz verificar que o filho não deve permanecer sob a guarda do pai ou da mãe, deferirá a guarda à pessoa que revele compatibilidade com a natureza da medida, considerados, de preferência, o grau de parentesco e as relações de afinidade e afetividade.

A leitura dos dispositivos acima transcritos demonstra que a guarda compartilhada deve ser sempre incentivada pelo Poder Judiciário, com a finalidade de resguardar, da forma mais ampla possível, a convivência familiar e, consequentemente, os interesses das crianças e dos adolescentes.

Através da guarda compartilhada, os pais assumem a responsabilidade conjunta pela criação dos seus filhos e pela tomada de decisões a respeito de aspectos fundamentais do desenvolvimento das crianças e/ou adolescentes, evitando-se sobrecarregar um único genitor com todas as obrigações advindas da paternidade, bem como privar um deles de participar ativamente da criação do filho. Neste sentido manifesta-se a doutrina:

\begin{abstract}
A guarda compartilhada é um modelo novo, cuja proposta é a tomada conjunta de decisões mais importantes em relação à vida do filho, mesmo após o término da sociedade conjugal.

(...) $\mathrm{O}$ que se garante é a continuidade da convivência familiar, que é um direito fundamental da criança e, por seu turno, um dever fundamental dos pais. A convivência, neste ínterim, não assume apenas a faceta do conviver e da coexistência, mas vai muito mais além, ou seja, participar, interferir, limitar, enfim, educar. Estes deveres não se rompem com o fim da conjugalidade, por força do artigo 1632 do Código Civil de 2002, por ser atributo inerente ao poder familiar, que apenas se extingue com a maioridade ou a emancipação do filho. Zelar pelo melhor interesse do menor, portanto, é garantir que ele conviva o máximo possível com ambos os genitores, desde que a convivência entre eles seja saudável, ou seja, que não exista nada que os desabone (...). ${ }^{145}$
\end{abstract}

145 PEREIRA, Rodrigo da Cunha. Princípios Fundamentais Norteadores do Direito de Família. Belo Horizonte: Del Rey, 2006. pp. 134-135. 


\begin{abstract}
A guarda compartilhada, por sua vez, importa na soma dos esforços e contribuição desses pais, na medida de suas possibilidades, para o atendimento de todas as necessidades dos filhos, em ambiente harmônico, propiciado pelo necessário equilíbrio nas decisões importantes para a prole, garantindo-lhes o convívio familiar que se estende além das relações de afeto com os genitores, e se projeta para a família que as crianças e adolescentes reconhecem como sua família, apesar do desenlace de seus pais, incluindo-se aí os avós, os tios, os primos e demais parentes paternos e maternos, em condição de igualdade (...). ${ }^{146}$
\end{abstract}

Caso a guarda compartilhada seja inviável, caberá ao magistrado conceder a guarda da criança ou do adolescente ao genitor que possuir mais condições de zelar pelo interesse do menor, levando em consideração os fatores da afetividade, da saúde, da segurança e da educação.

Nas hipóteses de guarda unilateral, deve ser garantido ao genitor que não a detiver o direito de visitas, com a finalidade de se manter o vínculo de afetividade entre pais e filhos, nos termos dispostos no artigo 1.589, do Código Civil:

\footnotetext{
Art. 1.589. O pai ou a mãe, em cuja guarda não estejam os filhos, poderá visitálos e tê-los em sua companhia, segundo o que acordar com o outro cônjuge, ou for fixado pelo juiz, bem como fiscalizar sua manutenção e educação.

Parágrafo único. $\mathrm{O}$ direito de visita estende-se a qualquer dos avós, a critério do juiz, observados os interesses da criança ou do adolescente. (Acrescentado pela L-012.398-2011)
}

Cumpre lembrar que a visita, ademais de ser um direito/dever dos pais, é direito fundamental dos filhos, ${ }^{147}$ sendo ideal que ela seja estabelecida da maneira mais ampla possível, a fim de possibilitar o estreitamento das relações familiares.

Entretanto, o mesmo princípio - princípio do melhor interesse do menor- que embasa a necessidade da fixação de um regime de visitas entre genitores e filhos, possibilita, em situações excepcionais, a sua limitação ou, até mesmo, a sua suspensão. ${ }^{148}$

\footnotetext{
${ }^{146}$ BOULOS, Kátia. Da Guarda "Com-Parte-lhada" à Guarda Compartilhada: Novos Rumos e Desafios. In SILVA, Regina Beatriz Tavares da; CAMARGO NETO, Theodureto de Almeida. Grandes Temas de Direito de Família e das Sucessões. São Paulo: Saraiva, 2011. p. 77.

${ }^{147}$ Como bem lembrado por Rolf Hanssen Madaleno, "São inenarráveis os sofrimentos causados pela privação do convívio do menor, quando um pai se afasta deliberadamente do seu rebento, geralmente movido pelo insano desejo de causar sofrimento à sua ex-mulher, mãe da criança, que nada fez para passar por essa reflexa e tão desumana punição. Noutra ponta, aparecem nos registros forenses demandas geradas pelos obstáculos e embaraços opostos pela mulher ao direito de visita do pai ao filho. São batalhas muitas vezes dramáticas e desgastantes deflagradas pela obstinação de certas mães- guardiãs, inconformadas com o direito do pai de conviver com o filho comum, nos estreitos horários que lhe são reservados no calendário de visita judicialmente fixado" (MADALENO, Rolf Hanssen. A guarda compartilhada pela ótica dos direitos fundamentais. In WELTER, Belmiro Pedro; MADALENO, Pedro Hanssen. Direitos Fundamentais do Direito de Família. Porto Alegre: Livraria do Advogado, 2004. p.349).
} 
Dessa maneira, o direito de visitas não é absoluto, devendo obediência ao princípio da dignidade da pessoa humana e à doutrina da proteção integral das crianças e dos adolescentes. Caso se demonstre que a presença do visitante é prejudicial aos interesses do menor, o magistrado deverá fixar um regime de visitas monitorado ou suspender o exercício do direito até que a situação danosa seja afastada.

Nas situações em que o convívio com o genitor puder representar riscos à integridade física ou mental da criança ou do adolescente, pode o magistrado determinar que as visitas sejam realizadas nas dependências do Poder Judiciário, com constante monitoramento de assistente social e de psicólogo. ${ }^{149}$ Esta medida, por óbvio, por ser extremamente prejudicial à manutenção dos vínculos de afeto entre pais e filhos, deve ser excepcional.

Pelo exposto até o momento, percebe-se que o nosso ordenamento jurídico resguarda a convivência familiar das crianças e adolescentes com sua família natural, valendo-se dos institutos da guarda compartilhada, da guarda extensiva e da visita como mecanismos de manutenção do vínculo afetivo entre pais e filhos, sempre que houver dissolução conjugal ou perda do poder familiar.

A adoção, objeto deste estudo, é vista como medida excepcional, mas não é menos relevante que as demais medidas de proteção previstas pelo nosso sistema jurídico interno (guarda e tutela). Tanto isso é verdade que, na impossibilidade de reinserção do menor em sua família natural, através do instituto da guarda e da tutela- fato, aliás, que não é incomum-, alternativa não resta ao Estado senão a colocação do menor em família substituta, por meio do processo judicial de adoção.

\footnotetext{
${ }^{148}$ Nesse sentido, vide artigo $9^{\circ}$, item 3, da Convenção sobre Direitos da Criança (1989): "Os Estados Partes respeitarão o direito da criança que esteja separada de um ou de ambos os pais de manter regularmente relações pessoais e contato direito com ambos, a menos que isso seja contrário ao interesse maior da criança".

${ }_{149}$ Alguns doutrinadores fazem severas críticas ao direito de visitas no Fórum, por entenderem que o ambiente não é propício à convivência familiar. Nesse sentido, conferir BOSCHI, Fábio Bauabi. Direito de Visita. São Paulo: Saraiva, 2006, p. 189. "A visitação no prédio do Fórum é uma das mais palpáveis imoralidades que, inconsciente e acriticamente, o Poder Judiciário vem repetindo no decorrer dos anos. Sob o aspecto constitucional, fere a fundo o direito da criança de receber a educação 'no lar e na escola', mas jamais, data máxima vênia da expressão pejorativa consagrada no vernáculo popular forense, no chiqueirinho. A rudeza da terminologia corriqueira nos foros bem revela, de imediato, a inconveniência que oferece a visitação naquele ambiente. É constrangedor para um pai consciente ter que visitar seu filho num espaço vigiado. É triste para a criança saber-se tão pouca merecedora de consideração. Como sonhará com a velha (ainda que ruidosa) família (...)". (grifo do autor)
} 
Frise-se que, em razão dos princípios até então analisados, o Estado tem como prioridade a não institucionalização definitiva de crianças e adolescentes, por ter em mente que os abrigos são incapazes de propiciar a estes indivíduos um ambiente saudável e propício ao seu pleno desenvolvimento.

Com a finalidade de minimizar os danos da alienação familiar, os abrigos ou entidades que oferecem acolhimento institucional devem adotar os seguintes princípios (exemplificativamente), de acordo com o disposto no artigo 92 do Estatuto da Criança e do Adolescente:

I - preservação dos vínculos familiares e promoção da reintegração familiar;

II - integração em família substituta, quando esgotados os recursos de manutenção na família natural ou extensa;

III - atendimento personalizado e em pequenos grupos;

IV - desenvolvimento de atividades em regime de co-educação;

V - não-desmembramento de grupos de irmãos;

VI - evitar, sempre que possível, a transferência para outras entidades de crianças e adolescentes abrigados;

VII - participação na vida da comunidade local;

VIII - preparação gradativa para o desligamento;

IX - participação de pessoas da comunidade no processo educativo.

Em 2006, o Governo Federal Brasileiro, reconhecendo a importância da convivência familiar e comunitária para o desenvolvimento das crianças e adolescentes, lançou o Plano Nacional de Promoção, Proteção e Defesa do Direito de Crianças e Adolescentes à Convivência Familiar e Comunitária, que institui diversas metas protetivas, a saber: ${ }^{150}$

a) participação no programa de "mutirão interinstitucional para revisão de casos de crianças e adolescentes sob medida protetiva de abrigo em entidade (art. 101, VII do ECA), iniciando-se pelos programas de acolhimento institucional financiados pelo Governo Federal;

b) implementação de ações de reintegração familiar;

c) adequação dos programas de acolhimento institucional à legislação vigente;

d) aprimoramento e consolidação dos procedimentos de adoção;

\footnotetext{
${ }^{150}$ As metas aqui mencionadas foram extraídas do artigo de Lúcia Maria Teixeira Ferreira e Sávio Renato Bittencourt. A adoção no início do terceiro milênio: para cada criança uma família- primeiros questionamentos. In PEREIRA, Tânia da Silva; OLIVEIRA, Guilherme de. Cuidado e vulnerabilidade. São Paulo: Atlas, 2009. pp. 217-218.
} 
e) regularização da situação de crianças e adolescentes que vivem em famílias com quem não possuem vínculo legalizado;

f) garantia de aplicação dos conceitos de provisoriedade e excepcionalidade dos programas de acolhimento institucional previstos no ECA;

g) aprimoramento dos instrumentos legais de proteção contra a suspensão ou destituição do poder familiar.

Em suma, pode-se constatar que o Estado, ainda que de forma gradativa, vem adotando todas as medidas necessárias, no âmbito dos Poderes Legislativo, Executivo e Judiciário, para a proteção do direito à convivência familiar e comunitária, em prol do pleno desenvolvimento das crianças e dos adolescentes.

\subsection{Princípio da afetividade}

A análise do princípio da afetividade foi deixada para o final do capítulo não pela sua importância diminuta, mas, muito pelo contrário, pela sua relevância e pela necessidade de se colher mais elementos para a sua apreciação.

Conforme visto nos itens anteriores, com o advento da Constituição de 1988 e a introdução do princípio da dignidade da pessoa humana como fundamento da República Federativa do Brasil, o ordenamento jurídico pátrio deixou de lado o caráter puramente patrimonial da família, valorizando o afeto como base do relacionamento entre seus integrantes.

A família moderna tem como principais fundamentos o afeto, o respeito e o estímulo, sendo o ambiente adequado para o desenvolvimento das potencialidades e da personalidade de seus integrantes. Nesse sentido: ${ }^{151}$

(...) a família é o locus de realização da afetividade, pois é nela que se realizam as experiências afetivas que vão moldar a personalidade e determinar a qualidade das relações a serem desenvolvidas pelos indivíduos na vida social e política. Conforme dissemos nas linhas acima, as relações familiares caracterizam-se pela interdependência econômica e afetiva entre os seus membros, de modo que é na família que os indivíduos se experienciam, trocam experiências afetivas,

${ }^{151}$ SANTOS, Romualdo Baptista dos. A Tutela Jurídica da Afetividade. Curitiba: Juruá, 2011.p. 153. 
aprendem a lidar com os afetos, e com isso, se constituem enquanto seres humanos e se desenvolvem com vista à vida em sociedade. Não é por outra razão que se afirma, desde tempos imemoriais, que a família é a célula-mater da sociedade, pois é no seu interior que se formam os indivíduos e, principalmente, que se formata o caráter das pessoas, preparando-as para a vida em sociedade.

A nossa Constituição Federal foi, inegavelmente, influenciada pela Declaração de Direitos da Criança, adotada pela Assembleia Geral da Organização das Nações Unidas (1959) e ratificada pelo Brasil pelo Decreto n. 99.710/1990, que estabelece que:

Princípio $2^{\circ}$ : A criança gozará de proteção social e ser-lhe-ão proporcionadas oportunidades e facilidades, por lei e por outros meios, a fim de lhe facultar o desenvolvimento físico, mental, espiritual, moral e social, de forma sadia e normal e em condições de liberdade e dignidade. $\mathrm{Na}$ instituição das leis visando este objetivo levar-se-ão em conta, sobretudo, os melhores interesses da criança.

Princípio $6^{\circ}$ : Para o desenvolvimento completo e harmonioso de sua personalidade, a criança precisa de amor e de compreensão. Criar-se-á, sempre que possível, aos cuidados e sob a responsabilidade dos pais e, em qualquer hipótese, num ambiente de afeto e de segurança moral e material (...).

Os princípios acima mencionados deixam claro que o desenvolvimento do vínculo de afetividade e de afinidade depende, diretamente, da convivência saudável entre os membros da família, levando-se sempre em consideração o melhor interesse das crianças e dos adolescentes.

À medida que o direito ao afeto ${ }^{152}$ conquistou terreno no ordenamento jurídico nacional- como consequência da dignidade da pessoa humana-, cedeu-se espaço para o reconhecimento da paternidade afetiva, lastrada não em laços de sangue, mas sim em laços de amor.

\footnotetext{
152 "O direito ao afeto é o sentimento maior que garante o agrupamento humano por um laço mais forte do que uma simples conjugação de interesses e, assim, dá consistência aos demais direitos humanos da família. Realmente, desde sua origem, a família é recoberta com um manto de ternura e carinho, de dedicação e empenho, mas também de responsabilidade para com quem se cativa. Esse manto protetor é o afeto, ao qual o direito deve dedicar especial atenção, sob pena de por em risco a própria garantia jurídica da família. Isso porque, o direito ao afeto é o mais imprescindível à saúde física e psíquica, à estabilidade econômica e social, ao desenvolvimento material e cultural de qualquer entidade familiar. Daí, contrario sensu, decorre um direito humano fundamental- que simultaneamente é uma obrigação- importante, a saber: o poder-dever de repelir o desafeto por formas jurídicas que o afastem da família, preventiva ou repressivamente, tais como, por exemplo, a educação e a penalização referentes a todas as formas físicas e psíquicas de violência doméstica, não só entre marido e mulher, mas a partir da efetiva proibição de submeter os filhos a castigos corporais desumanos, que afrontam e corroem o amor" (MALUF, Adriana Caldas do Rego Freitas Dabus. Direito das famílias. Amor e bioética. Rio de Janeiro: Elsevier, 2012. p. 60).
} 
Acerca do tema, importante mencionar a lição de Rodrigo da Cunha Pereira: ${ }^{153}$

Para que um filho verdadeiramente se torne filho, ele deve ser adotado pelos pais, tendo ou não vínculos de sangue que os vinculem. A filiação biológica não é nenhuma garantia da experiência da paternidade, da maternidade ou da verdadeira filiação. Portanto, é insuficiente a verdade biológica, pois a filiação é uma construção que abrange mito mais do que uma semelhança entre os DNA. Afinal, o que é essencial para a formação de alguém, para que possa tornar-se sujeito e capaz de estabelecer laço social é que uma pessoa tenha, em seu imaginário, o lugar simbólico de pai e de mãe. A presença do pai ou da mãe biológicos não é nenhuma garantia de que a pessoa se estruturará como sujeito. O cumprimento de funções paternas e maternas, por outro lado, é o que pode garantir uma estruturação biopsíquica saudável de alguém. Por isso, a família não é apenas um dado natural, genético ou biológico, mas cultural, insiste-se.

Resta claro, assim, que a paternidade não tem como principal fundamento a verdade biológica. Muito pelo contrário, ela está lastreada no afeto e na prestação de cuidado, devendo os pais zelar pelo desenvolvimento físico, psicológico, moral e espiritual de seus filhos.

Em 2004, o Tribunal de Alçada de Minas Gerais reconheceu o direito de afeto como princípio fundamental do Direito de Família, determinando a responsabilidade civil do pai que abandonou o filho, apesar de o menor ter buscado sua atenção. ${ }^{154}$

Em razão da importância e do pioneirismo deste julgamento, insta transcrever parte do voto que reconheceu o direito ao afeto como princípio jurídico:

No seio da família da contemporaneidade, desenvolveu-se uma relação que se encontra deslocada para a afetividade. Nas concepções mais recentes de família, os pais de família têm certos deveres que independem do seu arbítrio, porque agora quem os determina é o Estado.

Assim, a família não deve mais ser entendida como uma relação de poder, ou de dominação, mas como uma relação afetiva, o que significa dar a devida atenção às necessidades manifestas pelos filhos em termos, justamente, de afeto e de proteção.

Os laços de afeto e de solidariedade derivam da convivência e não somente do sangue.

$(\ldots)$

\footnotetext{
153 PEREIRA, Rodrigo da Cunha. Princípios Fundamentais Norteadores do Direito de Família. Belo Horizonte: Del Rey, 2006. p. 184.

154 “INDENIZAÇÃO DANOS MORAIS- RELAÇÃO PATERNO-FILIAL- PRINCÍPIO DA DIGNIDADE DA PESSOA HUMANA- PRINCÍPIO DA AFETIVIDADE. A dor sofrida pelo filho, em virtude do abandono paterno, que o privou do direito à convivência, ao amparo afetivo, moral e psíquico, deve ser indenizável, com fulcro no princípio da dignidade da pessoa humana" (TAMG, AC n ${ }^{0} 408550-7,7^{\mathrm{a}} \mathrm{CC}$, Relator Unias Silva, j. 01.04.04).
} 
O princípio da afetividade especializa, no campo das relações familiares, o macroprincípio da dignidade da pessoa humana, que preside todas as relações jurídicas e submete o ordenamento jurídico nacional.

No estágio atual, o equilíbrio do privado e do público pauta-se exatamente na garantia do pleno desenvolvimento da dignidade das pessoas humanas que integram a comunidade familiar.

No que respeita à dignidade da pessoa da criança, o artigo 227 da Constituição expressa essa concepção, ao estabelecer que é dever da família assegurar-lhe “com absoluta prioridade o direito à vida, à saúde, à alimentação, à educação, ao lazer, à profissionalização, à cultura, à dignidade, ao respeito, à liberdade e à convivência familiar e comunitária", além de colocá-la "à salvo de toda forma de negligência, de discriminação, exploração, violência, crueldade e opressão". Não é um direito oponível apenas ao Estado, à sociedade ou a estranhos, mas a cada membro da própria família.

Assim, depreende-se que a responsabilidade não se pauta tão-somente no dever alimentar, mas se insere no dever de possibilitar o desenvolvimento humano dos filhos, baseado no princípio da dignidade da pessoa humana.

(...)

Assim, ao meu entendimento, encontra-se configurado nos autos o dano sofrido pelo autor, em relação à sua dignidade, a conduta ilícita praticada pelo réu, ao deixar de cumprir seu dever familiar de convívio e educação, a fim de, através da afetividade, formar laço parental com seu filho, e o nexo causal entre ambos.

Alguns óbices foram levantados quando da prolação da decisão aqui mencionada: (i) impossibilidade de se obrigar os pais a amarem seus filhos ${ }^{155}$; (ii) inexistência de dever jurídico de afeto; (iii) existência de consequência jurídica para o abandono na lei civil, a saber: perda do poder familiar e (iv) impossibilidade de quantificação do abandono afetivo.

Na mesma linha dos obstáculos acima- que, diga-se, também foram utilizados, guardadas as devidas proporções, quando da construção da teoria da responsabilidade civil por dano moral-, o Superior Tribunal de Justiça reformou a decisão proferida pelo Tribunal de Alçada de Minas Gerais, em votação por maioria, e decidiu pela impossibilidade da reparação civil em caso de abandono afetivo, nos seguintes termos:

RESPONSABILIDADE CIVIL. ABANDONO MORAL. REPARAÇÃO. DANOS MORAIS. IMPOSSIBILIDADE.

1- A indenização por dano moral pressupõe a prática de ato ilícito, não rendendo ensejo à aplicabilidade da norma do artigo 159 do Código Civil de 1916 o abandono afetivo, incapaz de reparação pecuniária.

\footnotetext{
${ }^{155}$ Nas palavras de Fábio Konder Camparato, “O amor é uma doação completa e sem reservas não só das coisas que nos pertencem, mas da nossa própria pessoa. Aquele que ama torna-se despossuído de si mesmo: ele nada retém para si, mas tudo oferece ao outro. (...) o dever de amar, ao contrário do de ser justo, não engendra direitos, isto é, exigências da parte de outrem. Na ética evangélica, temos todos o dever de amar os outros, quaisquer outros, mesmo os inimigos. Mas, obviamente, nenhum daqueles que devemos amar pode exigir de nós esse comportamento. A grande função social do amor consiste, na verdade, em atuar como fator de permanente aperfeiçoamento da justiça. É o impulso constante no sentido de uma não acomodação com as formas da justiça já existentes; a procura de uma ampliação ilimitada do princípio de dar a todos e a cada um o que a consciência ética sente como devido. Disto, a História nos dá importantes testemunhos (COMPARATO, Fábio Konder. Ética. Direito, Moral e Religião no Mundo Moderno. $3^{\mathrm{a}}$ ed. São Paulo: Companhia das Letras, 2011.p. 534).
} 
2- Recurso especial conhecido e provido.

O voto vencido do Ministro Barros Monteiro, entretanto, representou importante precedente para a responsabilidade civil por abandono afetivo, ao afirmar que o dano decorre do abalo psíquico sofrido pelo filho, sendo o afeto inerente ao poder familiar.

Em outras palavras, o bom pai, diferentemente do que ocorria nos primórdios da humanidade, não tem apenas o dever de prover o sustento e as necessidades materiais da prole. Mais do que isso, os genitores possuem a obrigação de proporcionar aos filhos um ambiente familiar repleto de amor, carinho e compreensão. O suporte moral e o direcionamento espiritual fornecidos pelos genitores são mais relevantes que a mera ajuda financeira, fator que poderia ser obtido por terceiros.

Apesar do julgamento contrário proferido pelo Superior Tribunal de Justiça, muitos Tribunais nacionais, atentos às transformações operadas na entidade familiar e ao bemestar das crianças e dos adolescentes, continuaram reconhecendo o direito de afeto em suas decisões, sedimentando o caminho para uma futura mudança de entendimento do Superior Tribunal de Justiça.

Recentemente (24/04/2012), a Terceira Turma do Superior Tribunal de Justiça, ao julgar o Recurso Especial n. 1.159.242-SP, (Rel. Ministra NANCY ANDRIGHI) reconheceu, em consonância com a jurisprudência majoritária de alguns Tribunais estaduais, a responsabilidade civil por abandono afetivo, ${ }^{156}$ baseada no descumprimento do dever de cuidado. Nesse sentido:

CIVIL E PROCESSUAL CIVIL. FAMÍLIA. ABANDONO AFETIVO. COMPENSAÇÃO POR DANO MORAL. POSSIBILIDADE.

1. Inexistem restrições legais à aplicação das regras concernentes à responsabilidade civil e o consequente dever de indenizar/compensar no Direito de Família.

2. O cuidado como valor jurídico objetivo está incorporado no ordenamento jurídico brasileiro não com essa expressão, mas com locuções e termos que manifestam suas diversas desinências, como se observa do art. 227 da CF/88.

\footnotetext{
${ }^{156}$ O julgamento aqui mencionado não se deu de forma unânime. O Ministro Massami Uyeda votou pela improcedência do pedido, por entender que o reconhecimento da responsabilidade na hipótese de abandono afetivo permitiria a potencialização e a quantificação de mágoas íntimas.
} 
3. Comprovar que a imposição legal de cuidar da prole foi descumprida implica em se reconhecer a ocorrência de ilicitude civil, sob a forma de omissão. Isso porque o non facere, que atinge um bem juridicamente tutelado, leia-se, o necessário dever de criação, educação e companhia de cuidado - importa em vulneração da imposição legal, exsurgindo, daí, a possibilidade de se pleitear compensação por danos morais por abandono psicológico.

4. Apesar das inúmeras hipóteses que minimizam a possibilidade de pleno cuidado de um dos genitores em relação à sua prole, existe um núcleo mínimo de cuidados parentais que, para além do mero cumprimento da lei, garantam aos filhos, ao menos quanto à afetividade, condições para uma adequada formação psicológica e inserção social.

5. A caracterização do abandono afetivo, a existência de excludentes ou, ainda, fatores atenuantes - por demandarem revolvimento de matéria fática - não podem ser objeto de reavaliação na estreita via do recurso especial.

6. A alteração do valor fixado a título de compensação por danos morais é possível, em recurso especial, nas hipóteses em que a quantia estipulada pelo Tribunal de origem revela-se irrisória ou exagerada.

7. Recurso especial parcialmente provido.

Conforme se pode perceber pela leitura da ementa acima transcrita, o fundamento da responsabilidade civil por abandono afetivo foi o descumprimento do dever objetivo de cuidado, previsto em dispositivos esparsos do ordenamento jurídico, dentre eles o artigo 227 da Constituição Federal.

A Ministra relatora esclarece que alçando-se, no entanto, o cuidado "à categoria de obrigação legal supera-se o grande empeço sempre declinado quando se discute o abandono afetivo - a impossibilidade de se obrigar a amar”.

De fato, o descumprimento do dever de cuidado, que abarca em seu conteúdo, conforme já mencionado, a obrigação dos pais de zelar pelo afeto, pela saúde, pela segurança e pela educação dos filhos (deveres mencionados expressamente pelo Código Civil, ao tratar da guarda de crianças e adolescentes), possibilita o desenvolvimento da teoria da responsabilidade civil no campo do Direito de Família, sempre que se comprovar a caracterização do dano.

O Ministro Paulo de Tarso Sanseveriano deixou claro, porém, que a responsabilidade civil no campo do Direito de Família não pode ser equiparada à responsabilidade civil extracontratual, sob pena de se exigir, no trato "familiar diário, uma 
cautela incompatível com as relações que se firmam no âmbito da família, além de se conduzir a uma indesejável patrimonialização das relações pessoais ”.

Apesar da preocupação do i. Ministro ser fundada, não se pode esquecer que também no campo da responsabilidade civil extracontratual se exige que o interessado comprove cabalmente a configuração do dano, não se admitindo a indenização de meros incômodos ou desconfortos.

Frise-se que, na responsabilidade civil por dano afetivo, que envolve a violação de direitos inerentes à personalidade, a prova do dano pode ser obtida através de laudos técnicos, que comprovem que a conduta do genitor foi capaz de causar prejuízos ao pleno desenvolvimento físico e psicológico do filho.

A construção jurisprudencial analisada neste item acabou servindo de inspiração para o Projeto de lei n. 700/2007, de autoria do Senador Marcelo Crivella, que tem como intuito alterar alguns dispositivos do Estatuto da Criança e do Adolescente, para, dentre outras medidas, caracterizar o abandono afetivo como ilícito civil e penal.

Na justificação ao referido projeto de lei, o Senador esclarece que:

A lei não tem o poder de alterar a consciência dos pais, mas pode prevenir e solucionar os casos intoleráveis de negligência para com os filhos. Eis a finalidade desta proposta, e fundamenta-se na Constituição Federal, que, no seu artigo 227, estabelece, entre os deveres e objetivos do Estado, juntamente com a sociedade e a família, o de assegurar as crianças e adolescentes- além do direito à vida, à saúde, à alimentação, à educação, ao lazer- o direito à dignidade e ao respeito.

Mas como conferir dignidade e respeito às crianças e adolescentes, se estes não receberem a presença acolhedora dos genitores? Se os pais não lhes transmitem segurança, senão silêncio e desdém? Podem a indiferença e a distância suprir as necessidades da pessoa em desenvolvimento? Pode o pai ausente- ou a mãe omissa- atender aos desejos de proximidade, de segurança e de agregação familiar reclamados pelos jovens no momento mais delicado de sua formação? São óbvias as respostas a tais questionamentos.

(...)

Amor e afeto não se impõem por lei! Nossa iniciativa não tem essa pretensão. Queremos, tão-somente, esclarecer, de uma vez por todas, que os pais têm o DEVER de acompanhar a formação dos filhos, orientá-los nos momentos mais importantes, restar-lhes solidariedade, e, na medida do possível, fazerem-se presentes quando o menor reclama espontaneamente a sua companhia. 
Apenas a titulo exemplificativo, seguem algumas alterações sugeridas pelo Projeto de lei n. 700/2007:

Art. $1^{\circ} \mathrm{O}$ art. $4^{\circ}$ da Lei $\mathrm{n}^{\circ}$. 8.069, de 13 de julho de 1990 , passa avigorar acrescido dos seguintes $\S \S 2^{\circ}$ e $3^{\circ}$, renumerado o atual parágrafo único como $\S$ $1^{\mathrm{o}}$ :

"Art. $4^{\circ}$

$\S 1^{\mathrm{o}}$.

$\S 2^{\circ}$. Compete aos pais, além de zelar pelos direitos de que trata oart. $3^{\circ}$ desta Lei, prestar aos filhos assistência moral, seja por convívio, seja por visitação periódica, que permitam o acompanhamento da formação psicológica, moral e social da pessoa em desenvolvimento.

$\S 3^{\circ}$. Para efeitos desta Lei, compreende-se por assistência moral devida aos filhos menores de dezoito anos:

I - a orientação quanto às principais escolhas e oportunidades profissionais, educacionais e culturais;

II - a solidariedade e apoio nos momentos de intenso sofrimento ou dificuldade; III - a presença física espontaneamente solicitada pela criança ou adolescente e possível de ser atendida.(NR)"

Art. $2^{\circ}$ Os arts. $5^{\circ}, 22,24,56,58,129$ e 130 da Lei $n^{\circ} .8 .069$, de13 de julho de 1990, passam a vigorar com as seguintes alterações:

"Art. $5^{\circ}$.

Parágrafo único. Considera-se conduta ilícita, sujeita a reparação de danos, sem prejuízo de outras sanções cabíveis, a ação ou a omissão que ofenda direito fundamental de criança ou adolescente previsto nesta Lei, incluindo os casos de abandono moral. (NR)"

O Projeto de lei aqui analisado está na Comissão de Direitos Humanos e Participação Legislativa, sendo que, em 2010, o Relator Gerson Camata proferiu voto favorável à sua aprovação (posteriormente acompanhado pelos Relatores Eduardo Lopes e Demóstenes Torres), nos seguintes termos:

(...) a caracterização do abandono afetivo como conduta ilícita ainda é bastante controversa, causando incerteza quanto à resposta a essa conduta. Além do dever de guarda, os pais têm o dever de ter o filho em sua companhia, cumprindo uma das funções familiares mais importantes para a formação da personalidade dos membros da família: a dedicação de atenção e afeto. E, mesmo sendo consenso que a paternidade não gera apenas deveres de assistência material, mas também de formação moral e afetiva, essa questão ainda não está regulada.

Dessa forma, apesar de o ECA representar real avanço na garantia dos direitos de crianças e adolescentes, ainda faz-se necessário protegê-los contra o descaso afetivo, tão lesivo à sua formação.

Assim, cientes de que responsabilidade dos pais pelos filhos não se resume exclusivamente ao dever de alimentar, mas também ao dever de possibilitar seu desenvolvimento humano pleno, baseado no princípio da dignidade da pessoa humana, entendemos que a proposta corrige uma lacuna em nosso ordenamento jurídico e, por essa razão, é merecedora de nosso apoio.

A intenção do projeto é sedimentar o entendimento de que os pais possuem o dever de cuidar da prole, devendo-se entender por cuidado a obrigação de zelar pela saúde, pela 
segurança, pela educação e pelo afeto das crianças e dos adolescentes. O dever de afeto, assim, faz parte do conteúdo do dever mais abrangente de cuidado, não se confundindo, em absoluto, com a imposição de amar.

Negar a existência do princípio da afetividade, que permeia todo o Direito de Família, seria um retrocesso jurídico e a aceitação da irresponsabilidade dos pais em relação aos filhos. No atual estágio evolutivo da sociedade, é imprescindível que o Direito colabore para que a entidade familiar cumpra a sua função primordial, qual seja, a de formação da personalidade de seus integrantes.

Resta claro, porém, que o reconhecimento do direito de afeto e a consequente responsabilização civil do genitor que o viole é incapaz de remediar todos os problemas estruturais da entidade familiar, apesar de ser fundamental para a conscientização da função que a entidade familiar desempenha na sociedade.

Em hipóteses extremas, em que se constata que o núcleo familiar natural é incapaz de proporcionar à prole os cuidados necessários ao seu desenvolvimento, alternativa não resta ao ordenamento jurídico senão a promoção da família substituta, sob as modalidades de guarda, tutela ou adoção.

Sendo assim, a responsabilidade civil pelo abandono afetivo e a perda do poder familiar, com a consequente colocação das crianças e adolescentes em famílias substitutas, são medidas complementares, que têm como finalidade resguardar o melhor interesse do menor, promover a convivência familiar em ambiente permeado pelo afeto e conscientizar os pais de suas responsabilidades. 


\title{
CAPÍTULO 4 DO PROCESSO DE ADOÇÃO
}

\subsection{Breves considerações a respeito da adoção}

O sistema jurídico vigente, em especial após a edição da Lei n. 12.010/2009, trata a adoção como medida excepcional, privilegiando a manutenção dos vínculos da criança com a sua família natural ou estendida. Esta regra tem como objetivo evitar a institucionalização prolongada ${ }^{157}$ de crianças e adolescentes, incentivando a retomada da convivência familiar em ambiente equilibrado.

De acordo com a pesquisa realizada por Sávio Bittencourt, ${ }^{158}$ junto ao Instituto de Pesquisa Econômica Aplicada- IPEA, com base nos dados do "Levantamento Nacional dos Abrigos para Crianças e Adolescentes da Rede de Serviço de Ação Continuada":

\begin{abstract}
Os motivos de abrigamento da criança são a carência de recursos materiais da família $(24,1 \%)$, o abandono pelos pais ou responsáveis $(18,8 \%)$, a violência doméstica $(11,6 \%)$, a dependência química dos pais ou responsáveis $(11,3 \%)$, a vivência de rua $(7 \%)$, a prisão dos pais ou responsáveis $(3,5 \%)$ e o abuso sexual praticado por pais ou responsáveis $(3,3 \%)$, pais ou responsáveis portadores de deficiência $(2,1 \%)$, criança submetida a exploração no trabalho, tráfico ou mendicância $(1,8 \%)$, dentre outros. A orfandade é causa de abrigamento de apenas 5,2\% dos institucionalizados.

Veja-se que a pobreza, apontada como causa direta da institucionalização, é responsável por um quarto dos casos. Nas demais hipóteses, embora ela possa ser a causa remota da desestrutura emocional que cerca a família de origem, o abrigamento se dá como forma de proteger a criança de sua própria família: abandono, violência, dependência química, manutenção na rua e abuso sexual pelos pais, totalizando estas violações por parte de seus cuidadores diretos mais metade dos casos de abrigamento.
\end{abstract}

\footnotetext{
157 Sobre a institucionalização, conferir BITTENCOURT, Sávio. A Nova Lei de Adoção. Do Abandono à Garantia do Direito à Convivência Familiar e Comunitária. Rio de Janeiro: Lumen Jures, 2010, p. 32: “(...) Digno, do ponto de vista da Lei Maior, é viver em família. Por consequiência, o afastamento da criança desta convivência familiar é uma grave violação a um direito indisponível e deve ser imediatamente objeto de tutela por parte do Ministério Público e da Magistratura. Cada criança abrigada é credora de uma investigação seja em procedimento judicial de jurisdição voluntária, seja em inquérito civil presidido pelo Promotor de Justiça da Infância e Juventude, para levantar as causas de sua institucionalização e as possibilidades de retorno à sua família de origem. Verificada a impossibilidade desse retorno, sem risco e em tempo curto e previsível, o respeito ao mandamento constitucional obriga aos aplicadores da lei que promovam a destituição do poder familiar e que se encontre uma família adotiva para garantir sua criação com amor".

${ }^{158}$ BITTENCOURT, Sávio. A Nova Lei de Adoção. Do Abandono à Garantia do Direito à Convivência Familiar e Comunitária. Rio de Janeiro: Lumen Jures, 2010. p. 10.
} 
Apesar de ser apontada como a principal causa isolada do abrigamento, a pobreza não dá ensejo à destituição do poder familiar, devendo o Poder Público promover políticas de auxílio às famílias carentes, permitindo que as crianças sejam mantidas no seio de sua família natural.

No que se refere às demais causas de institucionalização acima mencionadas, a Nova Lei de Adoção, em consonância com o Plano Nacional de Promoção, Proteção e Defesa do Direito de Crianças e Adolescentes à Convivência Familiar e Comunitária, busca que as crianças sejam reintegradas em sua família biológica, após a solução dos problemas que levaram ao abandono.

Isto porque restou demonstrado que a grande maioria das crianças institucionalizadas possui família e ainda mantém com ela algum tipo de vínculo, sendo a reaproximação familiar a medida mais adequada à proteção dos interesses destas pessoas em situação de vulnerabilidade. Neste sentido:

\begin{abstract}
Segundo dados do Levantamento Nacional de Abrigos para Crianças $e$ Adolescentes da Rede SAC realizado em 2003, apresentados no Plano, $58,2 \%$ das crianças e adolescentes abrigados tinham família e vínculo com ela. Dos que tinham família, mas não tinham vínculo, somavam $22,7 \%$. Apenas $4,6 \%$ não tinham família. Como pressupõe e requer a destituição do poder familiar, somente $10,7 \%$ estavam judicialmente em condições de serem encaminhados para a adoção.

O quadro encontrado levou à conclusão de que o problema não se remetia tão somente à necessidade de encontrar famílias adotivas para essas crianças e adolescentes, mas de resolver também o dilema da maioria deles, que se encontrava numa situação de nem poder ao menos ser adotada. A opção legislativa, nesse sentido, foi a de então tentar primeiro resgatar o vínculo com a família natural, sem o intuito de desmerecer o instituto da adoção.

Por isso, a Lei Nacional de Adoção trata como excepcional a medida da colocação em família substituta, preconizando a permanência da criança [e do adolescente] junto a sua família de origem (...). ${ }^{159}$
\end{abstract}

Neste contexto, vale lembrar que os Grupos de Apoio à Adoção realizam importante trabalho na reaproximação das crianças com suas famílias de origem, por meio do desenvolvimento de projetos que valorizam a convivência familiar e combatem a institucionalização prolongada.

${ }^{159}$ TAKAHASHI, Estela Mayumi. A adoção no Brasil. In SILVA, Regina Beatriz Tavares da; CAMARGO NETO, Theodureto de Almeida Camargo. Grandes Temas de Direito de Família e das Sucessões. São Paulo: Saraiva, 2011. p. 291. 
Somente nos casos em que a reintegração da criança em sua família natural se mostra inviável, em virtude da permanência das causas da institucionalização, é que se pode falar em desconstituição do poder familiar e, consequentemente, em adoção. Em outras palavras, a adoção é vista pelo sistema jurídico vigente como medida excepcional, a ser indicada somente quando inviável a reaproximação da criança com a sua família de origem.

Apesar de excepcional e causada por problemas de desequilíbrio social indesejados, a adoção não deixa de ser uma alternativa válida para a inserção de crianças e adolescentes em famílias equilibradas, capazes de lhes proporcionar as condições adequadas para o seu desenvolvimento. Nesse sentido:

\begin{abstract}
Os relacionamentos das famílias adotivas são frequentemente fundados na miséria humana. Os pais biológicos geralmente entregam seus filhos para adoção ou os abandonam porque são forçados pela pobreza ou pela discriminação ou pelo caos que advém da guerra ou outro desastre. Muitos interessados na adoção são forçados a escolher esta forma de paternidade em razão da infertilidade. Em um mundo ideal, nós iríamos eliminar as doenças sociais que forçam alguns a desistirem de seus filhos e que impedem outros de sua fertilidade. Mas o argumento deste livro é que no mundo em que vivemos hoje e viveremos amanhã, as doenças sociais com as quais somos familiares existem e continuarão existindo. A adoção deveria ser entendida como uma instituição que funciona bem para os pais biológicos, para os adotantes e para as crianças. $\mathrm{O}$ outro argumento é que a adoção não deveria ser vista simplesmente como uma solução parcial para as doenças sociais do mundo. A adoção deveria ser entendida como uma alternativa positiva à família baseada em laços sanguíneos. ${ }^{160}$
\end{abstract}

Dessa maneira, por ser a adoção uma medida válida e positiva, as tentativas de reaproximação da criança com sua família biológica devem encontrar limites nos princípios da proporcionalidade e do melhor interesse da criança. Isto porque não é razoável que a criança passe anos em acolhimento institucional ou familiar, aguardando que seus genitores encontrem o equilíbrio necessário para lhes dar afeto e estabilidade. A

\footnotetext{
${ }^{160}$ BARTHOLET, Elizabeth. Family Bonds: Adoption, Infertility, and the New World of Child Production. Boston: Beacon Press, 1999. pp. xxiv-xxv: "Adoptive family relationships are often built in a foundation of human misery. Birth parents generally surrender children for adoption or abandon them because they feel forced to do so by poverty or discrimination or the chaos that results from war or some other disaster. Many of those interested in becoming adoptive parents feel forced to undertake this form of parenting by infertility. In an ideal world, we would eliminate the social ills that force some to give up the children they bear and that deprive others of their infertility. But the argument of this book is that in the world in which we live today and will live tomorrow, the social ills with which we are familiar do and will exist. Adoption should be understood as an institution that works well for birth parents, for the infertile, and for children. The further argument is that adoption should not be seen simply as a partial solution for some of the world's social ills. Adoption should be understood as a positive alternative to the blood-based family form".
} 
busca pela reaproximação familiar não deve jamais prejudicar os interesses da criança, conforme relatado por Sávio Bittencourt: ${ }^{161}$

\begin{abstract}
$\mathrm{Na}$ verdade sempre se erra contra a criança. Ela pode esperar no abrigo enquanto os adultos são tratados, encontram empregos, largam vícios, se equilibram emocionalmente. Considerando que a recuperação de adultos com problemas não é só uma questão de dinheiro, mas envolve um trabalho com toda a formação psicossocial da pessoa, pode-se prever que as tentativas de reintegração não sejam fáceis, em grande parte dos casos. Aliás, há pessoas que evidentemente não podem ficar com crianças, porque não reúnem condições para garantir sua saúde física e mental, quando não atentam diretamente contra a sua vida ou incolumidade, como demonstraram as pesquisas acima mencionadas. Um violador de direitos fundamentais não pode ficar com a criança em nome de um afeto imaginário, idealizado (...).
\end{abstract}

Atento a esta realidade, o artigo 19, $\S 1^{\circ}$ do Estatuto da Criança e do Adolescente, acrescido pela Lei n. 12.010/2209, prevê que "toda criança ou adolescente que estiver inserido em programa de acolhimento familiar ou institucional terá a sua situação reavaliada, no máximo, a cada seis meses (...)”. Esta análise permitirá que a equipe interdisciplinar emita um parecer sobre a viabilidade da recolocação da criança em sua família de origem ou sobre a conveniência da adoção.

De qualquer forma, a Lei n. 12.010/2009 prevê que a institucionalização de crianças e adolescentes pode perdurar por um período máximo de dois anos, "salvo comprovada necessidade que atenda ao seu superior interesse, devidamente fundamentada pela autoridade judiciária”, deixando claro que o abrigamento deve ser sempre medida provisória, em razão do princípio da convivência familiar e comunitária.

Caso reste comprovado que a recolocação da criança na sua família natural não é a medida mais adequada, sendo viável a adoção, alternativa não resta aos interessados senão a provocação do Poder Judiciário, uma vez que a adoção por escritura pública foi completamente excluída do nosso ordenamento jurídico.

Conforme se verá a seguir, o processo judicial de adoção possui uma série de peculiaridades, em virtude da relevância dos interesses que pretende resguardar. No Brasil, toda e qualquer adoção- seja ela de adolescentes ou de crianças- deve ser precedida de controle judicial, nos termos dos ensinamentos abaixo:

${ }^{161}$ BITTENCOURT, Sávio. A Nova Lei de Adoção. Do Abandono à Garantia do Direito à Convivência Familiar e Comunitária. Rio de Janeiro: Lumen Jures, 2010. p. 42. 
Desde o advento da Constituição Federal, a adoção perdeu a natureza predominantemente contratual, tendo ganhado contornos próprios de instituto de ordem pública. O sucesso da adoção não depende mais tão somente da vontade do adotante e dos pais biológicos, mas também deve atender aos interesses do adotando. Quando se tratar de crianças, a manifestação de vontade delas será suprida pelo Estado, representado pelo juiz. Em se tratando de adolescentes, é necessário o seu consentimento.

Desse modo, o controle judicial passou a integrar o processo de adoção. $\mathrm{O}$ vínculo de filiação constitui-se por meio de sentença e produz efeitos a partir do trânsito em julgado, exceto na hipótese de falecimento do adotante no curso do procedimento, caso em que tem força retroativa à data do óbito. Por haver interesses de incapazes em jogo, é necessária a intervenção do Ministério Público. ${ }^{162}$

Feitas estas considerações preliminares, resta a análise do processo de adoção propriamente dito, regulamentado pelo Estatuto da Criança e do Adolescente.

\subsection{Procedimento e peculiaridades do processo de adoção}

Conforme mencionado acima, a adoção de crianças no Brasil depende da prévia manifestação do Poder Judiciário, nos autos de processo de jurisdição voluntária ou contenciosa, permeado de peculiaridades em razão dos interesses que pretende resguardar.

Os interessados em adotar uma criança ou adolescente devem requerer a sua inscrição nos cadastros mantidos pela autoridade judiciária, em cada comarca ou foro regional, nos termos do artigo 50 do Estatuto da Criança e do Adolescente, cuja redação foi alterada pela Lei n. 12.010/2009.

O pedido de inscrição será analisado por uma equipe interprofissional, bem como pelos órgãos técnicos do Juizado da Infância e da Juventude e pelo Ministério Público, sendo indeferido pelo magistrado quando não preenchidos os requisitos legais ou quando restar claro que os interessados não têm condições de zelar pelos interesses da criança envolvida.

O Juízo da Infância e da Juventude da Comarca deve manter cadastros tanto dos brasileiros e estrangeiros que desejam adotar, como das crianças em condições de serem

162 TAKAHASHI, Estela Mayumi. A adoção no Brasil. In SILVA, Regina Beatriz Tavares da; CAMARGO NETO, Theodureto de Almeida Camargo. Grandes Temas de Direito de Família e das Sucessões. São Paulo: Saraiva, 2011. pp. 303-304. 
adotadas, dando prioridade às adoções nacionais ${ }^{163}$, sendo que a violação desta obrigação implica em sanção administrativa.

Questão interessante diz respeito à necessidade ou não de o Poder Judiciário seguir a ordem cronológica de inscrição dos interessados previamente cadastrados. Como regra, o magistrado somente pode deferir a adoção em favor de pessoa cadastrada.

Entretanto, o artigo 50, $§ 13$ do Estatuto da Criança e do Adolescente, cuja redação foi acrescida pela Lei n. 12.010/2009, prevê o deferimento da adoção em favor de pessoas não cadastradas quando: (1) se tratar de adoção unilateral; (2) o pedido for formulado por parente próximo, que mantenha com a criança vínculos de afinidade e afetividade e (3) os interessados já detiverem a guarda ou tutela da criança maior de três anos, ${ }^{164}$ comprovada a existência de laços de afeto e de afinidade.

Vale lembrar que a doutrina, antes mesmo da edição da Nova Lei de Adoção, já admitia a adoção de crianças e adolescentes por pessoas não cadastradas ou fora da ordem cronológica do cadastro, em respeito ao princípio do melhor interesse da criança. Nesse sentido:

\footnotetext{
${ }^{163}$ Nesse sentido: “A ordem de preferência será a seguinte: em primeiro lugar, a adoção favorecerá os pretensos adotantes cadastrados na Comarca do adotando, obedecida a ordem de cadastro mantido pela Justiça da Infância e da Juventude. Não havendo sucesso, serão consultados o cadastro estadual e, posteriormente, o cadastro nacional de pessoas ou casais habilitados a adotar. Somente depois de esgotadas as possibilidades dentro do país, serão consultados os distintos cadastros de pessoas e de casais residentes em Estado estrangeiro.

Mesmo havendo interessados brasileiros não cadastrados, mas residentes no Brasil e que preenchem os requisitos para habilitação, estes preferem aos estrangeiros cadastrados, se ambos demonstrarem interesse pela mesma criança ou adolescente" (RIBEIRO, Paulo Hermano Soares; SANTOS, Vívian Cristina Maria; SOUZA, Ionete de Magalhães. Nova Lei de Adoção Comentada. $2^{\mathrm{a}}$ ed. Leme: J.H.Mizuno, 2012. pp. 167168).

${ }^{164}$ A previsão de que a criança tenha a idade mínima de três anos para se admitir a aplicação da exceção prevista no inciso III, parágrafo 13 do artigo 50 do ECA foi objeto de críticas pela doutrina: "Na verdade, no afã de regulamentar a matéria de forma peremptória, a lei acabou exagerando ao dispor, no inciso III do artigo em comento, para outra exceção à regra da obediência ao cadastro, contemplando apenas quem tenha a guarda e a tutela de criança maior de 3 (três) anos ou adolescente, desde que o lapso de tempo de convivência comprove a fixação de laços de afinidade e afetividade e que não se vislumbre a má-fé. O dispositivo é bem intencionado, mas peca por estipular uma idade mínima (três anos) para que possa existir a exceção. (...) Não é possível, em função do mandamento constitucional de prioridade absoluta, que se negue uma adoção a uma criança, quando esta solução atender melhor seus interesses, mesmo que não esteja presente o requisito de sua idade mínima de três anos. É uma solução que não pode ser banalizada, é verdade. Mas em casos absolutamente excepcionais, a existência de vínculo da criança com o interessado justifica a solução também excepcional. O vínculo não se cria ou forma apenas após os três anos. Essa suposição legal nem sempre atenderá o comando constitucional, e quando isso acontecer a restrição será inconstitucional e não poderá ser aplicada" (BITTENCOURT, Sávio. A Nova Lei de Adoção. Do Abandono à Garantia do Direito à Convivência Familiar e Comunitária. Rio de Janeiro: Lumen Juris, 2010. pp. 138-139).
} 
É importante ressaltar, todavia, que o cadastro existe para disciplinar a adoção de crianças, evitando que fatores distantes do interesse destas influenciem a escolha de determinado habilitado em detrimento de outros. A compra de crianças, a corrupção de servidores públicos e outras anomalias são dificultadas por este sistema. A obrigatoriedade do cadastro é uma regra salutar, informada pelo princípio da igualdade, mas essencialmente submetida ao princípio do melhor interesse da criança. Vale dizer, nas hipóteses excepcionais em que o cumprimento do cadastro se demonstre inconveniente para a criança, deve ser aplicada ao caso concreto a solução que conferir melhor proteção ao infante, já que seu direito à família é juridicamente superior ao interesse de qualquer pessoa que queira adotá-la, ainda que anteriormente cadastrada.

Com efeito, se uma criança tem características que demonstrem a inconveniência da adoção pelo primeiro habilitado da lista, em função da incompatibilidade entre o perfil da criança e do interessado, deve ele ser preterido, entregando-se a criança aos cuidados de outro habilitado cadastrado, o primeiro que seja subseqüente que tenha melhor condição de assumir a responsabilidade (...). ${ }^{165}$

Na mesma linha de raciocínio, deve ser mencionado o acórdão do Superior

Tribunal de Justiça que reconheceu a relatividade dos cadastros, nos termos da ementa abaixo transcrita:

RECURSO ESPECIAL - ADOÇÃO - CADASTRO DE ADOTANTES RELATIVIDADE - PRINCÍPIO DA PREVALÊNCIA DO INTERESSE DO MENOR - VÍNCULO AFETIVO DA MENOR COM CASAL DE ADOTANTES DEVIDAMENTE CADASTRADOS - PERMANÊNCIA DA CRIANÇA POR APROXIMADAMENTE DOIS ANOS, NA SOMATÓRIA DO TEMPO ANTERIOR E DURANTE O PROCESSO - ALBERGAMENTO PROVISÓRIO A SER EVITADO - ARTIGO 197-E, § $1^{\circ}$, DO ECA PRECEDENTES DESTA CORTE - RECURSO ESPECIAL PROVIDO.

1.- A observância do cadastro de adotantes, ou seja, a preferência das pessoas cronologicamente cadastradas para adotar determinada criança, não é absoluta. A regra comporta exceções determinadas pelo princípio do melhor interesse da criança, base de todo o sistema de proteção. Tal hipótese configura-se, por exemplo, quando já formado forte vínculo afetivo entre a criança e o pretendente à adoção, ainda que no decorrer do processo judicial. Precedente.

2.- No caso dos autos, a criança hoje com 2 anos e 5 meses, convivia com os recorrentes há um ano quando da concessão da liminar (27.10.2011), permanecendo até os dias atuais. Esse convívio, sem dúvida, tem o condão de estabelecer o vínculo de afetividade da menor com os pais adotivos.

3.- Os Recorrentes, conforme assinalado pelo Acórdão Recorrido, já estavam inscritos no CUIDA - Cadastro Único Informatizado de Adoção e Abrigo o que, nos termos do artigo 197-E, do ECA, permite concluir que eles estavam devidamente habilitados para a adoção. Além disso, o $\S 1^{\circ}$, do mesmo dispositivo legal afirma expressamente que "A ordem cronológica das habilitações somente poderá deixar de ser observada pela autoridade judiciária nas hipóteses previstas no $\S 13$ do art.50 desta Lei, quando comprovado ser essa a melhor solução no interesse do adotando".

4.- Caso em que, ademais, a retirada do menor da companhia do casal com que se encontrava há meses devia ser seguida de permanência em instituição de acolhimento, para somente após, iniciar-se a busca de colocação com outra família, devendo, ao contrário, ser a todo o custo evitada a internação, mesmo que em caráter transitório.

165 BITTEnCOURT, Sávio. A Nova Lei de Adoção. Do Abandono à Garantia do Direito à Convivência Familiar e Comunitária. Rio de Janeiro: Lumen Juris, 2010. pp. 130-131. 
5.- A inobservância da preferência estabelecida no cadastro de adoção competente, portanto, não constitui obstáculo ao deferimento da adoção quando isso refletir no melhor interesse da criança.

6.- alegações preliminar de nulidade rejeitadas.

7.- Recurso Especial provido.

(REsp 1347228/SC, Rel. Ministro SIDNEI BENETI, TERCEIRA TURMA, julgado em 06/11/2012, DJe 20/11/2012)

Ressalte-se que o princípio do melhor interesse da criança e a prevalência dos vínculos afetivos são causas, também, para o reconhecimento da validade das chamadas adoções intuitu personae, nas quais os pais naturais selecionam os adotantes que julgam adequados para os seus filhos. ${ }^{166}$ Nesse sentido:

RECURSO ESPECIAL - AFERIÇÃO DA PREVALÊNCIA ENTRE O
CADASTRO DE ADOTANTES E A ADOÇÃO INTUITU PERSONAE -
APLICAÇÃO DO PRINCÍPIO DO MELHOR INTERESSE DO MENOR -
VEROSSÍMIL ESTABELECIMENTO DE VÍNCULO AFETIVO DA MENOR
COM O CASAL DE ADOTANTES NÂO CADASTRADOS -
PERMANÊNCIA DA CRIANÇA DURANTE OS PRIMEIROS OITO MESES
DE VIDA - TRÁFICO DE CRIANÇA - NÃO VERIFICAÇÃO - FATOS QUE,
POR SI, NÃO DENOTAM A PRÁTICA DE ILÍCITO - RECURSO ESPECIAL
PROVIDO. I - A observância do cadastro de adotantes, vale dizer, a preferência das pessoas cronologicamente cadastradas para adotar determinada criança não é absoluta. Excepciona-se tal regramento, em observância ao princípio do melhor interesse do menor, basilar e norteador de todo o sistema protecionista do menor, na hipótese de existir vínculo afetivo entre a criança e o pretendente à adoção, ainda que este não se encontre sequer cadastrado no referido registro;

II - É incontroverso nos autos, de acordo com a moldura fática delineada pelas Instâncias ordinárias, que esta criança esteve sob a guarda dos ora recorrentes, de forma ininterrupta, durante os primeiros oito meses de vida, por conta de uma decisão judicial prolatada pelo i. desembargador-relator que, como visto, conferiu efeito suspensivo ao Agravo de Instrumento n.1.0672.08.277590-5/001. Em se tratando de ações que objetivam a adoção de menores, nas quais há a primazia do interesse destes, os efeitos de uma decisão judicial possuem o potencial de consolidar uma situação jurídica, muitas vezes, incontornável, tal como o estabelecimento de vínculo afetivo;

\footnotetext{
${ }^{166}$ Há autores que entendem que esta é a modalidade de adoção mais justa e que mais atende aos interesses das partes envolvidas. Nesse sentido: "Se a mãe não pode assumir o filho e consente a adoção, seria necessário permitir um encontro entre a mãe e um casal que procura adotar uma criança, ao cabo do qual esta seria registrada em nome dos novos pais. Isso teria como resultado uma mãe tranqüilizada pela doação de seu bebê a um casal feliz e uma criança saudável. Todas as adoções deveriam se dar assim: a criança doada pela mãe, com o tempo e a possibilidade de conversar com ela e lhe dizer: 'Eu te confio a este senhor e a esta senhora, que serão teu pai e tua mãe'. Esse ato é simbolicamente justo e verdadeiro, pois a criança entende que sua mãe a confia a seus pais e que ela é imediatamente registrada no nome deles. Deixa de ser, então, um segredo para a criança e passa a ser um segredo compartilhado com os pais, pois a mãe a pôs a par desde o início. É assim que as crianças deveriam ser adotadas. Esse modo de adoção, atualmente clandestino e ilegal, seria o mais humano. A adoção é um ato privado, íntimo. Uma mãe gestante, que não tem a possibilidade de criar seu filho, se ela o ama por ele mesmo, deve ser ajudada a confiá-lo a um casal que, desde o primeiro dia, está decidido a criá-lo: essas pessoas ficarão reconhecidas à mãe gestante pela alegria que lhes dá confiandolhes seu filho (DOLTO, Françoise. Destinos de crianças: adoção, famílias de acolhimento, trabalho social. São Paulo: Martins Fontes, 1998. pp. 84-85).
} 
III - Em razão do convívio diário da menor com o casal, ora recorrente, durante seus primeiros oito meses de vida, propiciado por decisão judicial, ressalte-se, verifica-se, nos termos do estudo psicossocial, o estreitamento da relação de maternidade (até mesmo com o essencial aleitamento da criança) e de paternidade e o consequente vínculo de afetividade;

IV - Mostra-se insubsistente o fundamento adotado pelo Tribunal de origem no sentido de que a criança, por contar com menos de um ano de idade, e, considerando a formalidade do cadastro, poderia ser afastada deste casal adotante, pois não levou em consideração o único e imprescindível critério a ser observado, qual seja, a existência de vínculo de afetividade da infante com o casal adotante, que, como visto, insinua-se presente;

$\mathrm{V}$ - O argumento de que a vida pregressa da mãe biológica, dependente química e com vida desregrada, tendo já concedido, anteriormente, outro filho à adoção, não pode conduzir, por si só, à conclusão de que houvera, na espécie, venda, tráfico da criança adotanda.

Ademais, o verossímil estabelecimento do vínculo de afetividade da menor com os recorrentes deve sobrepor-se, no caso dos autos, aos fatos que, por si só, não consubstanciam o inaceitável tráfico de criança;

VI - Recurso Especial provido.

(REsp 1172067/MG, Rel. Ministro MASSAMI UYEDA, TERCEIRA TURMA, julgado em 18/03/2010, DJe 14/04/2010).

Cumpre lembrar, porém, que a adoção fora da ordem cronológica de inscrição, por pessoas não cadastradas ou por pessoas escolhidas pelos pais biológicos, deve ser concedida de forma cautelosa, sempre em regime de exceção, sob pena de se admitir a burla do procedimento legal, estabelecido com a finalidade de resguardar os interesses das crianças envolvidas. Não é demais ressaltar que a previsão dos cadastros teve como causa, justamente, a preservação do interesse da criança.

Deferida a inscrição dos interessados, os mesmos devem requerer a adoção por meio de petição dirigida ao juiz, observados os requisitos previstos no artigo 165, do Estatuto da Criança e do Adolescente, nos seguintes termos:

Artigo 165. São requisitos para a concessão de pedidos de colocação em família substituta:

I- qualificação completa do requerente e de seu eventual cônjuge ou companheiro, com expressa anuência deste;

II- indicação de eventual parentesco do requerente e de seu cônjuge, ou companheiro, com a criança ou adolescente, especificando se tem ou não parente vivi;

III- qualificação completa da criança ou adolescente e de seus pais, se conhecidos;

IV- indicação do cartório onde foi inscrito o nascimento, anexando, se possível, uma cópia da respectiva certidão;

V- declaração sobre a existência de bens, direitos ou rendimentos relativos à criança ou adolescente.

Parágrafo único. Em se tratando de adoção observar-se-ão também os requisitos específicos. 
Em se tratando de pedido de colocação de criança em família substituta sob a modalidade de adoção, devem estar presentes, ainda, os requisitos (1) da idade, (2) da aprovação de contas do requerente tutor ou curador, (3) do consentimento dos pais ou representante legal do adotando, (4) do consentimento do adotando, quando maior de 12 anos e (5) da condição eventual de requerente estrangeiro.

Conforme se percebe pela leitura do artigo 165, acima transcrito, o legislador não exige que a inicial seja instruída com atestados de sanidade física e mental e, tampouco, documento que comprove a idoneidade moral do pretenso adotante. Tal omissão encontra fundamento no fato de que estes requisitos serão analisados na fase de instrução do processo, sendo desnecessária e, até mesmo inútil, a juntada dos referidos documentos na fase inicial.

O artigo 166, caput do Estatuto, ${ }^{167}$ permite que os interessados elaborem o pedido de adoção diretamente em cartório, sem o patrocínio de advogado, desde que os pais da criança ou adolescente sejam ignorados, tenham falecido, hajam sido destituídos ou suspensos do pátrio poder ou tenham, de maneira expressa, aderido ao pedido.

Como bem esclarece Antônio Cézar Peluso, ${ }^{168}$ ao comentar o artigo 166, caput do ECA:

Esta concordância pode ser manifestada na mesma petição ou em documento que a instrua; mas, para efeito de controle da eficácia de ato de tamanha magnitude jurídica que, como declaração de vontade, só basta quando seja veraz, consciente, livre e firme, os pais serão ouvidos logo, em audiência especial mas reservada (art. 206, caput), mediante termo de declarações, pelo juiz e, por intermédio dele, pelo representante do Ministério Público. A audiência há de ser imediata, precedendo, de qualquer modo, a deliberação das diligências instrutórias (art. 167), porque concerne a pressuposto de simplificação do procedimento: retratando-se os pais ou não bastando a concordância, o juiz marcará o prazo de 10 dias para que seja a inicial emendada e subscrita por patrono legalmente habilitado, com adoção do rito contraditório (artigo 284 do $\mathrm{CPC})$.

\footnotetext{
167 "Se os pais forem falecidos, tiverem sido destituídos ou suspensos do poder familiar; ou haverem aderido expressamente ao pedido de colocação em família substituta, este poderá ser formulado diretamente em cartório, em petição assinada pelos próprios requerentes, dispensada a assistência de advogado".

${ }^{168}$ PELUSO, Antônio Cézar. Da Colocação em Família Substituta. In CURY, Munir (coord.). Estatuto da Criança e do Adolescente Comentado. Comentários Jurídicos e Socais. 12ª ed. São Paulo: Malheiros, 2013. p. 804 .
} 
Como se pode perceber pela leitura do dispositivo acima mencionado, o legislador teve a intenção de simplificar o procedimento de adoção, nos casos em que não esteja presente a resistência ao pedido, fazendo-se desnecessário o cumprimento dos princípios do contraditório e da ampla defesa.

Frise-se, entretanto, que tal simplificação não chega ao ponto de tornar dispensável a análise dos atributos morais e psicológicos dos interessados, sendo necessária a realização de instrução processual para comprovação de que os pretensos adotantes possuem condições de zelar pelo desenvolvimento saudável e pelo melhor interesse dos adotandos. Nesse sentido:

Artigo 167. A autoridade judiciária, de ofício ou a requerimento das partes ou do Ministério Público, determinará a realização de estudo social ou, se possível, perícia por equipe interprofissional, decidindo sobre a concessão da guarda provisória, bem como, no caso de adoção, sobre o estágio de convivência.

Dessa maneira, os estudos realizados por equipe interprofissional, presentes em todos os processos que visam a colocação de crianças em família substituta, têm como finalidade permitir que o juiz analise se os interessados possuem condições de oferecer ao adotando uma lar estruturado e contínuo.

Estes estudos, que serão objeto de análise mais detalhada neste capítulo, oferecem importante substrato para o magistrado decidir sobre a conveniência da medida e a fixação do período do estágio de convivência.

O estágio de convivência foi regulamentado pelo artigo 46 do Estatuto da Criança e do Adolescente (cujos parágrafos foram alterados pela Lei n. 12.010/2209), que assim prevê:

A adoção será precedida de estágio de convivência com a criança ou adolescente, pelo prazo que a autoridade judiciária fixar, observadas as peculiaridades do caso.

$\S 1^{\circ} \mathrm{O}$ estágio de convivência poderá ser dispensado se o adotando já estiver sob a tutela ou guarda legal do adotante durante tempo suficiente para que seja possível avaliar a conveniência da constituição do vínculo.

$\S 2^{\circ}$ A simples guarda de fato não autoriza, por si só, a dispensa da realização de estágio de convivência.

$\S 3^{\circ} \mathrm{Em}$ caso de adoção por pessoa ou casal residente ou domiciliado fora do país, o estágio de convivência, cumprido no território nacional, será de, no mínimo, 30 (trinta) dias. 
$\S 4^{\circ} \mathrm{O}$ estágio de convivência será acompanhado pela equipe interprofissional a serviço da Infância e da Juventude, preferencialmente com apoio dos técnicos responsáveis pela execução da política de garantia do direito à convivência familiar, que apresentarão relatório minucioso acerca da conveniência do deferimento da medida.

Trata-se do período em que a criança é confiada aos cuidados dos adotantes, para que seja averiguada a conveniência da medida. Leia-se "conveniência" como a capacidade de preservação dos interesses da criança pelos adotantes, por meio de afeto, cuidado, educação, suporte moral etc.

O período do estágio de convivência é fixado pelo magistrado de acordo com as peculiaridades de cada caso, não havendo na lei nenhuma previsão de prazo máximo ou mínimo. Não restam dúvidas, porém, de que as crianças maiores precisam de um período de adaptação mais extenso, em virtude de suas vivências e dos laços mantidos com a sua família de origem, ao passo que as crianças de tenra idade exigem um período menor de adaptação.

Nesta linha de raciocínio, devem ser mencionados os ensinamentos de Maria Josefina Becker: ${ }^{169}$

O estágio de convivência é o período necessário para que seja avaliada a adaptação da criança ou adolescente à sua nova família. A flexibilidade do prazo, e, mesmo, a possibilidade de dispensa do mesmo, no caso de bebês de menos de um ano, está de acordo com a diversidade de situações existentes. No caso de crianças muito pequenas, a adaptação depende fundamentalmente dos pais adotivos e se assemelha bastante à adaptação dos novos pais biológicos com seu recém-nascido. Nesses casos, é mais importante o período de espera, em que o acompanhante técnico é de muita utilidade. Seria como uma gestação psicossocial, em que todos os aspectos relativos à adoção, as necessidades e direitos de uma criança, as expectativas e fantasias dos futuros pais adotivos, devem ser franca e amplamente ventilados. É conveniente que as equipes técnicas que lidam com a adoção sejam bem preparadas, pois de seu trabalho dependerá, e muito, o sucesso da medida.

No caso de crianças mais velhas e de adolescentes, é prudente ficar um estágio de convivência mais dilatado, para que dê tempo, sem pressões, para que o conhecimento mútuo permita o estabelecimento dos vínculos. Não é demais lembrar que essas crianças e adolescentes já vivenciaram rejeições e rupturas e foram, inclusive, muitas vezes, alvo de maus-tratos e abusos. Aqui, mais uma vez, é de inestimável valor a presença da equipe técnica, para acompanhar o processo de adaptação e oferecer o apoio e os esclarecimentos necessários tanto aos pais adotivos quanto às crianças ou adolescentes. O processo adotivo de crianças mais velhas é menos conhecido em nosso País, e certamente necessita especial atenção por parte das autoridades e dos técnicos especializados, para que um número maior de destinatários possa ser beneficiado com a medida.

169 BECKER, Maria Josefina. Da Adoção. In CURY, Munir. Estatuto da Criança e do Adolescente Comentado. Comentários Jurídicos e Sociais. 12a ed. São Paulo: Malheiros, 2013. p. 216. 
Cabe ressaltar, entretanto, que os pareceres técnicos não possuem o condão de vincular o magistrado, que é livre para decidir da maneira mais benéfica aos interesses da criança, de acordo com o seu convencimento (fundado, por óbvio, nos demais elementos constantes dos autos).

Apresentado o relatório social ou o laudo pericial, o juiz deve marcar audiência para a oitiva da criança ou para o consentimento do adolescente. ${ }^{170}$

A regra da obrigatoriedade de oitiva da criança ou do consentimento do adotante, prevista pelos artigos $28, \S \S 1^{\circ}$ e $2^{\circ}$ e $45, \S 2^{\circ}$ do Estatuto da Criança e do Adolescente, está de acordo com o disposto no artigo 12, da Convenção sobre os Direitos da Criança, da Organização das Nações Unidas, que assim dispõe:

1- Os Estados-Partes garantirão à criança, que é capaz de formar a sua própria opinião, o direito de expressá-la livremente em todos os assuntos que afetam-na, sendo esta opinião tomada na devida consideração, de acordo com a sua idade e maturidade.

2- Para esta finalidade, a criança deverá ter a oportunidade de ser ouvida em qualquer processo judicial ou administrativo que lhe diga respeito, seja diretamente, seja por intermédio de um representante ou de uma instituição apropriada, na conformidade das regras processuais da lei local.

Tal prerrogativa é corolário do reconhecimento da criança como sujeito de direito (e não mero objeto, a ser manipulado pelos pais), sendo a sua oitiva (ou o seu consentimento) fundamental para a decisão a ser proferida pelo magistrado nos processos de adoção. Vale lembrar, afinal, que todo o processo de adoção é permeado pelo princípio do melhor interesse da criança, devendo o magistrado considerar a opinião do adotando sobre os adotantes e sobre a própria adoção. ${ }^{171}$

${ }^{170}$ Nesse sentido, prescreve o artigo 168 do ECA: “Apresentado o relatório social ou o laudo pericial e
ouvida, sempre que possível, a criança ou adolescente, dar-se-á vista dos autos ao Ministério Público, pelo
prazo de cinco dias, decidindo a autoridade judiciária em igual prazo".
${ }^{171}$ Como bem lembrado por Sávio Bittencourt, muitas crianças e adolescentes são resistentes à adoção, por
medo de se afeiçoarem aos pais e serem rejeitados. Nesse sentido: "Na experiência de visita a abrigos de
crianças, onde a tônica é a permanência por longos períodos em arrepio ao que determinam a lei e o bom
senso, bem como na vivência das famílias adotivas, pode se perceber que há crianças que se encontram
afastadas sentimentalmente de suas famílias de origem, mas que rechaçam a ideia da adoção. Também no
seio da família substituta, em adaptação, a criança que teve um tempo de abrigamento longo ou sentiu de
forma acentuada seu abandono pela família biológica, costuma ter um comportamento indesejável. Nos casos
que vivenciei pude perceber que- em sua totalidade- a criança ou adolescente testa o amor dos pais adotivos,
criando dificuldades comportamentais e demonstrando dificuldade em entregar-se sentimentalmente. Tanto
nos casos de crianças ainda institucionalizadas como nos casos das que têm dificuldade de adaptação, está
presente um grande medo da entrega de algo tão precioso que é o seu 'querer-bem'. Este bem afetivo tão 
Ocorre, porém, que a norma internacional acima mencionada (Convenção sobre Direitos da Criança, da ONU), não prevê em que idade a criança possui discernimento para expressar a sua opinião, fato que levou o professor Jacob Dolinger a sustentar a aplicação analógica do disposto na Convenção sobre Sequestro, nos seguintes termos:

\begin{abstract}
Sobre a idade em que a criança já tem discernimento para expressar sua opinião, nada foi especificado pelas Convenções, podendo-se fazer a seguinte dedução: como a convenção sobre seqüestro deixa de se aplicar quando a criança atinge 16 anos de idade, por determinação de seu artigo $4^{\circ}$, e como em seu artigo 13 admite ouvir a criança se tiver idade e discernimento, conclui-se que antes de alcançar a idade de 16 anos já pode ser considerada com maturidade suficiente para expressar o que pensa sobre a medida solicitada. A aferição da maturidade da criança dependerá, em cada caso, do entendimento da autoridade judicial $(\ldots) .{ }^{172}$
\end{abstract}

A questão, porém, é controversa. Muitos doutrinadores entendem que a fixação de um limite de idade não soluciona o problema, uma vez que a contribuição da opinião da criança para a decisão judicial depende mais da sua maturidade e do seu discernimento do que da sua idade. ${ }^{173}$ Nesta linha de raciocínio, deve ser transcrito o posicionamento de Eduardo de Oliveira Leite:

\begin{abstract}
A partir de que idade é possível considerar que uma criança pode ser ouvida em um processo que lhe diz respeito?

As opiniões se dividiram, entendo uns que o discernimento só é possível determinar a partir de determinada idade e outros que essa qualidade é possível detectar independentemente de qualquer limite de idade.
\end{abstract}

delicado e essencial, que nós só conseguimos compartilhar quando nossa autoestima se encontra satisfatória. $\mathrm{O}$ que dizer de uma criança cuja história de abandono e desamor trucidou seu amor próprio? Seu comportamento de pirraça e falsa indiferença é um grande pedido de socorro e de amor verdadeiro" (SILVA, Sávio Renato Bittencourt Soares. Guia do Pai Adotivo. Orientações para uma Adoção Feliz. $2^{\mathrm{a}}$ ed. Curitiba: Juruá, 2012. p. 61). (grifo do autor)

${ }_{172}$ DOLINGER, Jacob. Direito Internacional Privado. A Criança no Direito Internacional. Rio de Janeiro: Renovar, 2003. p. 130.

${ }^{173}$ Nas palavras de Gustavo Ferraz de Campos Mônaco e Maria Luiza Ferraz de Campos, “(...) já se pode vislumbrar que embora a questão da maturidade possa ser considerada, quando relacionada com as questões de vínculos paternos-filiais mostra-se extremamente relativa, pois tais vínculos já podem ser estabelecidos e detectados desde os primeiros momentos de vida de uma criança. Se de extrema importância para outras questões, como as relativas à responsabilização criminal, às decisões relativas à própria segurança e às considerações referentes à capacidade de aprendizagem e maturação, já na questão das relações familiares que definam o melhor interesse da criança na convivência familiar com cada uma de seus pais, os indícios de maturidade detectáveis já se encontram presentes desde os primeiros momentos de vida. Decorre daí, a importância da audição da criança, independentemente de sua idade, do domínio da linguagem falada, e de seu grau de maturidade. Até porque, a maturidade, embora conceito amplamente utilizado e que se justifica para as decisões importantes, como as acima citadas, é extremamente vago e relativo para outras questões, como a que define o final da adolescência e o início da vida adulta, o quantum de afeto dirigido a cada pai, ou a escuta e atendimento de necessidade por cada um deles (...) (MÔNACO, Gustavo Ferraz de Campos; CAMPOS, Maria Luiza Ferraz de. O direito de audição de crianças e jovens em processo de regulação do exercício do poder familiar. Arte Jurídica: Biblioteca Científica de Direito Civil e Processo Civil da Universidade Estadual de Londrina, Curitiba, 2006. v. 3, p. 97). 


\begin{abstract}
Alguns juristas chegaram mesmo a sustentar que o limite de idade é sempre arbitrário, invocando como argumento justificador de suas posições a impossibilidade de determinação o discernimento com base no mero elemento idade. Assim, alegam que uma criança com 7 anos de idade pode ser perfeitamente capaz de discernir entre o correto e o errado, entre o que lhe é ou não vantajoso, socorrendo-se das pesquisas feitas pelos assistentes sociais, que demonstram jovens crianças de 6 a 8 anos com uma visão bem clara e sobretudo honesta da situação na qual se encontram, enquanto outras crianças, com mais de 12 anos, manifestam-se completamente alheias ao que está efetivamente ocorrendo (...). ${ }^{174}$
\end{abstract}

O artigo $28, \S 1^{\circ}$ do ECA prevê que a criança ou o adolescente será ouvido pela equipe interdisciplinar, sempre que possível, "respeitado seu estágio de desenvolvimento e grau de compreensão sobre as implicações da medida, e terá sua opinião devidamente considerada”.

Sobressaem-se da análise do dispositivo aqui mencionado três elementos, a saber: (1) o destinatário da oitiva; (2) a obrigatoriedade da oitiva e (3) as qualidades do adotando.

A norma, alterada pela Lei n. 12.010/2009, prevê que a criança ou o adolescente será ouvido por equipe interprofissional, formada por psicólogos e assistentes sociais, e não pelo magistrado. Esta alteração teve como finalidade resguardar, da forma mais ampla possível, o interesse da criança, já que a equipe interprofissional está mais habilitada a avaliar a manifestação do adotando do que o magistrado.

Frise-se, entretanto, que o art. 28 do Estatuto da Criança e do Adolescente não impede que o magistrado opte por ouvir a criança ou o adolescente, a fim de confirmar as percepções dos assistentes sociais e psicólogos e formar a sua convicção. Afinal, somente após ouvir o adotando, poderá o magistrado verificar se ele possui maturidade suficiente para expressar as suas impressões sobre os adotantes.

É conveniente, porém, que o juiz tenha em mente que todo depoimento de crianças oferece pontos de vulnerabilidade, tais como: “(a) a questão das falsas memórias; (b) a suscetibilidade da criança à sugestão de falsa informação e (c) o efeito da emoção negativa

${ }^{174}$ LEITE, Eduardo de Oliveira. Estudos de Direito de Família e Pareceres de Direito Civil. Em homenagem à Dra. Regina Bilac Pinto, a "Grande Dama” da editoração jurídica brasileira. Rio de Janeiro: Forense, 2011.p. 307. 
na memória". ${ }^{175}$ Em razão disso, a avaliação e a consideração da manifestação do adotando devem ser feitas de forma cautelosa, com fundamento não apenas na linguagem, como também no comportamento da criança.

Apesar de o artigo mencionar que a criança e o adolescente serão ouvidos sempre que possível, a interpretação sistemática do Estatuto da Criança e do Adolescente (e do próprio dispositivo legal em análise) demonstra que a oitiva do adotando é um dever e não um poder do Juízo. Tendo em vista que a medida afetará diretamente a vida do adotando, ele deve ser ouvido pelos profissionais- sempre que esta oitiva seja possível, considerandose as suas condições pessoais-, a fim de que a medida seja aplicada da forma mais vantajosa aos seus interesses. ${ }^{176}$

Cumpre lembrar, ademais, que a oitiva da criança e a análise de sua manifestação pela equipe interprofissional devem levar em consideração o estágio de desenvolvimento e o discernimento do adotando quanto às consequências do processo, permitindo a aplicação pelo magistrado da medida mais adequada ao caso concreto, evitando experiências desastrosas e dificuldades de relacionamento.

Na lição de Luiz Paulo Santos Aoki:

Isto implica reconhecer-se como imperativo legal e, portanto, exigível por todos e cada um, o respeito ao estágio de desenvolvimento das crianças ou adolescentes que serão postos em lar substituto, ou seja, exige-se um estudo acurado e fundamentado dos profissionais habilitados que se entrevistarem com tais crianças e adolescentes, que deve explicitar de forma clara e consistente qual o estágio de desenvolvimento em que estes se encontram, de molde a possibilitar ao Promotor de Justiça e ao Magistrado a oportunidade de observar qual a

\footnotetext{
${ }^{175}$ LEITE, Eduardo de Oliveira. Estudos de Direito de Família e Pareceres de Direito Civil. Em homenagem à Dra. Regina Bilac Pinto, a "Grande Dama” da editoração jurídica brasileira. Rio de Janeiro: Forense, 2011. p. 317.

${ }^{176}$ Nesse sentido, conferir Luiz Paulo Santos Aoki: “A expressão Sempre que possível, constante do $\S 1^{\circ}$, informa a freqüência com que deve ser adotada a providência de indagar da criança ou do adolescente sobre a sua opinião a respeito da família a que vai pertencer, isto é, toda vez que houver a possibilidade de eles se manifestarem, deverão sempre ser ouvidos, não se referindo esta possibilidade a atributo pertinente ao juízo ou à ocasião processual, mas a condição de a criança ou adolescente manifestar-se a respeito de ato que vai diretamente influenciá-los dali em diante. É dever do juízo e direito da criança e do adolescente. Isto fica mais claro ainda por seguir-se o mandamento, e não a opção legal, traduzida no termo deverá, sinalizando que trata-se de ordem, obrigação, e não faculdade concedida ao juízo de colher a opinião daquele posto sob uma família substituta. Assim, desde que possível colher-se tal manifestação de vontade, esta deverá ser colhida, pois o mandamento é imperativo quando a criança ou adolescente tem condições de se expressar e, de qualquer modo, manifestar sua preferência (...)” (AOKI, Luiz Paulo Santos. Da Família Substituta. In CURY, Munir. Estatuto da Criança e do Adolescente Comentado. Comentários Jurídicos e Sociais. $12^{\mathrm{a}}$ ed. São Paulo: Malheiros, 2013.p. 143). (grifos nossos).
} 
medida, e quando, será melhor aplicada, atento ainda para a consonância entre aqueles que serão postos sob a responsabilidade de uma família substituta e os entes que a compõe, ou qual delas apresenta melhores condições de receber um novo ser com aquele estágio de desenvolvimento.

Certamente a observância destas condições de desenvolvimento da criança ou adolescente permitirão evitar fracassos desastrosos no ajustamento destes com a família receptora.

(...)

Exige a lei, agora, a expressa observância ao grau de compreensão sobre as implicações da medida, ou seja, o respeito à capacidade da criança e do adolescente de entender o que resultará da aplicação da medida de colocação em família substituta. ${ }^{177}$

Realizada a prova pericial, colhida a manifestação da criança ou do adolescente pela equipe interprofissional e a concordância do adolescente em audiência, o juiz estará apto a proferir sentença, que constituirá o vínculo da filiação.

As regras sobre a sentença no processo de adoção são previstas pelo artigo 47 do Estatuto da Criança e do Adolescente, nos seguintes termos:

O vínculo da adoção constitui-se por sentença judicial, que será inscrita no registro civil mediante mandado do qual não se fornecerá certidão.

$\S 1^{\circ} \mathrm{A}$ inscrição consignará o nome dos adotantes como pais, bem como o nome de seus ascendentes.

$\S 2^{\circ} \mathrm{O}$ mandado judicial, que será arquivado, cancelará o registro original do adotado.

$\S 3^{\circ}$ A pedido do adotante, o novo registro poderá ser lavrado no Cartório de Registro Civil do Município de sua residência.

$\S 4^{\circ}$ Nenhuma observação sobre a origem do ato poderá constar nas certidões de registro.

$\S 5^{\circ}$ A sentença conferirá ao adotado o nome do adotante e, a pedido de qualquer deles, poderá determinar a modificação do prenome.

$\S 6^{\circ}$ Caso a modificação do prenome seja requerida pelo adotante, é obrigatória a oitiva do adotando, observado o disposto nos $\S \S 1^{\circ}$ e $2^{\circ}$ do art. 28 desta Lei.

$\S 7^{\circ}$ A adoção produz seus efeitos a partir do trânsito em julgado da sentença constitutiva, exceto na hipótese prevista no $\S 6^{\circ}$ do art. 42 desta Lei, caso em que terá força retroativa à data do óbito.

$\S 8^{\circ} \mathrm{O}$ processo relativo à adoção assim como outros a ele relacionados serão mantidos em arquivo, admitindo-se o seu armazenamento em microfilme ou por outros meios, garantida a sua conservação para consulta a qualquer tempo.

Conforme se pode perceber pela leitura do dispositivo legal, a sentença judicial constituirá o vínculo da filiação entre adotante e adotando, sendo o seu registro equivalente a um registro de nascimento tardio. Em virtude da proibição de discriminação entre os filhos nascidos ou não do casamento, é vedada qualquer anotação no registro civil sobre a adoção.

177 AOKI, Luiz Paulo Santos. Da Família Substituta. In CURY, Munir. Estatuto da Criança e do Adolescente Comentado. Comentários Jurídicos e Sociais. 12a ed. São Paulo: Malheiros, 2013. p.145. 
A proibição de menção da adoção no registro de nascimento da criança ou do adolescente não impede, porém, que o adotando tenha acesso ao processo de adoção e, consequentemente, à verdade biológica. ${ }^{178}$

Tanto isso é verdade que, com a finalidade de preservar a identidade do adotando (corolário do direito de personalidade), o artigo 48 do Estatuto da Criança e do Adolescente, alterado pela Lei n. 12.010/2009, estabelece a prerrogativa de o adotando conhecer a sua origem biológica, nos seguintes termos:

\begin{abstract}
$\mathrm{O}$ adotado tem direito de conhecer sua origem biológica, bem como de obter acesso irrestrito ao processo no qual a medida foi aplicada e seus eventuais incidentes, após completar 18 (dezoito anos).

Parágrafo único. $\mathrm{O}$ acesso ao processo de adoção poderá ser também deferido ao adotado menor de 18 (dezoito) anos, a seu pedido, assegurada assistência jurídica e psicológica.
\end{abstract}

Ressalte-se que a previsão de assistência jurídica e psicológica ao adotando menor de dezoito anos, que demonstra interesse em conhecer seus pais biológicos ou o seu passado, teve como fundamento, muito provavelmente, a crença fundada em pesquisas realizadas nos Estados Unidos de que estes indivíduos ainda não têm condições de lidar com dois pais e/ou duas mães durante o período da formação de sua identidade. Restou demonstrado que as crianças e os adolescentes ficam um pouco confusos e não sabem a quem devem lealdade.

\footnotetext{
178 "A adoção é o maior exemplo de que os laços de amor não se fundamentam em vínculos biológicos e de que a paternidade tem menos de determinismo genético e mais de escolha. Entretanto, a valorização da paternidade biológica, ainda latente na sociedade atual, implica uma constante e infindável angústia nos pais adotivos quando se trata de revelar ao filho a verdade sobre a adoção. Tal verdade assume dois aspectos diversos: a verdade quanto ao fato da adoção e aquela concernente à identificação dos pais biológicos. Desde a instituição da legitimação adotiva no Brasil, posteriormente convertida em adoção plena, a lei determina que os laços do adotado com a família biológica são rompidos, impondo, inclusive, a modificação do registro civil, para que não conste nenhuma informação sobre a adoção em certidões eventualmente extraídas. As disposições legais mencionadas têm como finalidade integrar o adotado emocionalmente na família dos adotantes, bem como estabelecer a igualdade entre os filhos, biológicos e adotivos. Com o intuito de preservar o adotado e os pais adotivos, o Direito terminou por relegar a verdade a segundo plano. (...) A ruptura dos laços com a família de origem e o estabelecimento do segredo quanto à adoção começaram a sofrer questionamentos no final do século XX. Embora se deva reconhecer o mérito de tais normas, que pretendiam proteger os interesses dos adotados, eles próprios recorreram ao Judiciário para questioná-las. Foram eles que, em número cada vez maior, passaram a pleitear um direito de à informação acerca da sua ascendência biológica.Diante da preocupação atual em garantir sempre o melhor interesse da criança, muitos juristas começaram a defender uma modalidade de adoção que não fundava suas bases na 'reconstrução da identidade do adotado'. Assegurava, ao contrário, que ele pudesse ser acompanhado pela família natural e pela família adotiva. A essa modalidade foi conferido o nome de adoção aberta, em oposição à adoção fechada, ou closed adoption, que rompe os laços com a família biológica" (AULER, Juliana de Alencar. Adoção e direito à verdade sobre a própria origem. Belo Horizonte, Revista de Jurisprudência Mineira, v. 61, n. 194, pp.6-27, jul./set 2010).
} 
Nesse sentido, vale a pena mencionar as observações de Marianne Berry: ${ }^{179}$

O maior risco da adoção aberta, de acordo com os profissionais que militam nesta área, é a possibilidade de interferência no processo de ligação afetiva entre os pais adotivos e a criança, e, como conseqüência, no desenvolvimento e na adaptação saudável do adotado.

(...) crianças pequenas não estão preparadas para lidar com os diferentes valores de dois pais e podem rejeitar ambos, aumentando o risco de patologias psíquicas. Dessa maneira, ao invés de resolver os conflitos de identidade que surgem na adolescência, o contato com os pais biológicos pode aumentar a confusão dos adotados.

Ressalte-se que o Estatuto da Criança e do Adolescente, neste aspecto, foi além da norma internacional. Isto porque, a Convenção Relativa à Proteção das Crianças e à Cooperação em Matéria de Adoção Internacional, apesar da orientação da Conferência da Haia de Direito Internacional privado, perdeu a oportunidade de tratar do direito à informação sobre a adoção, em matéria internacional. Nesse sentido:

Essa convenção (Convenção Relativa à Proteção das Crianças e à Cooperação em Matéria de Adoção Internacional), que teve grande sucesso do ponto de vista de sua aceitação pelos Estados, não conseguiu, todavia, pôr fim a grave problema atinente ao direito de a criança adotada conhecer a sua origem biológica. A Conferência da Haia de Direito Internacional Privado, ainda antes da assinatura da Convenção de 1993, deixou registrada a necessidade de que a futura convenção sobre a adoção tratasse da questão atinente ao direito à informação da criança, dos pais biológicos e dos pais adotivos em matéria internacional.

(...) $\mathrm{O}$ confronto confidencialidade versus abertura decorre primordialmente da contraposição entre a adoção simples e a adoção plena, uma vez que na primeira se mantenham alguns laços entre a família biológica e a criança adotada, ao passo que na segunda forma de adoção mencionada apenas as relações atinentes aos impedimentos matrimoniais mantêm-se presentes, extinguindo-se todas as demais relações. Trata-se, assim, de um problema cultural. Os países em desenvolvimento entendem que a confidencialidade é a melhor regra inclusive para resguardar a família adotiva de possíveis extorsões perpetradas pela família biológica. Aqueles que adotam o sistema de abertura de dados o fazem por privilegiar o suposto direito (não declarado, nem positivado) atinente ao conhecimento da verdade biológica. Fato é que, apesar das expectativas criadas a respeito da pacificação da questão, os Estados partes não chegaram a nenhum acordo quando da assinatura da convenção. ${ }^{180}$

\footnotetext{
${ }^{179}$ BERRY, Marianne. Risks and Benefits of Open Adoption. The Future of Children. Adoption, vol. 3, n.1, p. 129, Spring 1993. "The biggest risk of open adoption postulated by most adoption professionals is that it will interfere with the process of bonding between adoptive parents and child, which in turn will interfere with the adopted child's healthy development and adjustment. (...) young child is not equipped to deal with the differing value systems of two sets of parents and may reject both value systems, increasing the risk of psychopathology. Thus, instead of helping to resolve identity conflicts in adolescence, contact with birthparents may increase an adoptees's confusion".

180 MÔNACO, Gustavo Ferraz de Campos. A Proteção da Criança no Cenário Internacional. Belo Horizonte: Del Rey, 2005. pp. 264-267.
} 
Dessa maneira, pela lei brasileira, a criança tem o direito de conhecer a sua verdade biológica, ${ }^{181}$ não só por motivos pessoais e para a formação de sua identidade, como também por motivos de saúde. ${ }^{182}$

Ocorre que, alguns pais, com medo de perderem o amor e o respeito de seus filhos, preferem esconder as origens de sua filiação. Este comportamento, apesar de compreensível, acaba por prejudicar o desenvolvimento da criança ${ }^{183}$ e abalar a confiança estabelecida entre os adotantes e os adotados. ${ }^{184}$

Como bem lembrado por Maria Josefina Becker:

181 “A partir de um decreto-lei de 1941, a França autorizou as mulheres que assim requeressem dar à luz numa maternidade sem revelar a identidade. O pessoal das maternidades inscrevia um X no lugar do sobrenome, o que foi denominado de 'parto sob X'. Um novo parágrafo da lei, datado de 8 de janeiro de 1993, instituiu o reconhecimento do parto secreto: 'Quando do parto a mãe pode pedir que o segredo de sua internação e de sua identidade seja preservado'. A França, contudo, é o único país europeu, junto com Luxemburgo, a dispor de tal possibilidade, e essa lei se choca com a Convenção Internacional dos Direitos da Criança, que torna obrigatório o acesso de todos às suas origens, estipulado que a criança, 'desde seu nascimento' e 'na medida do possível', tem o direito de conhecer seus pais a ser criada por eles. Os especialistas encarregados de fazer propostas para colocar o direito francês em conformidade com o direito internacional ressaltam a necessidade de não confundir anonimato e segredo. $\mathrm{O}$ anonimato apaga todo vestígio de identidade, não cabendo, pois, ação de busca de maternidade, ao passo que o segredo poderia conciliar o conhecimento da identidade da mãe pela Assistência Social à Infância, que a guardaria secreta, com a possibilidade, para a criança, de apelar mais tarde, se desejar, para um mediador encarregado de aproximá-la da mãe de origem e, em caso de recusa desta, poder consultar seu registro de nascimento, após um prazo de prescrição" (DOLTO, Françoise. Destinos de crianças: adoção, famílias de acolhimento, trabalho social. São Paulo: Martins Fontes, 1998. pp. 79-80).

${ }^{182}$ Nesse sentido, conferir: RIBEIRO, Paulo Hermano Soares; SANTOS, Vívian Cristina Maria; SOUZA, Ionete de Magalhães. Nova Lei de Adoção Comentada. 2a ed. Leme: J.H.Mizuno, 2012. p. 155.

${ }^{183}$ Verificar BERRY, Marianne. Risks and Benefits of Open Adoption. The Future of Children. Adoption, vol. 3, n.1, p. 128, Spring 1993: "For children who are adopted when older and who know and remember their birthparents, continuing contact with their birthparents may be especially appropriate. (...) They are individuals with a past history in another family and the ideas and beliefs about family life that history has spawned. If adoptive parents avoid dealing with their children's history, they are denying those children a part of their identity. Opens adoptions that acknowledge an older child's history and preadoptive genealogy should therefore support a more complete identity development. ("Para as crianças que foram adotadas quando mais velhas e que conhecem e se lembram de seus pais biológicos, a manutenção do contato com os mesmos pode ser a medida mais apropriada. (...) Elas são indivíduos com uma história em outra família e com ideias e crenças que essa mesma família criou. Se os pais adotivos evitarem lidar com a história familiar dos seus filhos, eles estarão negando a estas crianças uma parte de sua identidade. As adoções adoção abertas, que reconhecem o passado da criança e sua genealgogia, acabam por possibilitar um completo desenvolvimento da identidade do adotado").

184 "Certos pais adotivos desejam manter o segredo das origens dos filhos, o que me parece derivar essencialmente do imaginário. Como se a ignorância de suas origens aproximasse mais a criança dos pais adotivos ou, em outro sentido, como se a criança que nada sabe dos pais de nascimento fosse filha biológica da fantasia dos pais adotivos! A experiência nos mostra, porém, o contrário. A terapia dos filhos nos ensina que consciente ou inconscientemente, eles sabem tudo de sua história, e que apenas o não-dito, o mutismo dos terapeutas e dos pais, não os autoriza a tomar consciência dela. O não-dito, as lacunas na história pessoal engendram graves traumatismos, que muitas vezes são a base de neuroses, até de psicoses, dessas crianças" (DOLTO, Françoise. Destinos de crianças: adoção, famílias de acolhimento, trabalho social. São Paulo: Martins Fontes, 1998. pp. 87-88). 
Parece importante, no entanto, considerar que, por mais radical e definitiva, a adoção não tem o poder de revogar o passado. Em que pese a igualdade incontestável de direitos e qualificações em relação aos filhos havidos biologicamente, isto não deve significar que a construção dos vínculos familiares deva-se dar sobre a negação da verdade. Os conhecimentos da Psicologia Clínica e da Psiquiatria Infantil revelam que a presença do segredo familiar é extremamente danosa para a estruturação da personalidade. Por mais bem guardado que seja, o segredo gera sempre muita ansiedade, e essa perpassa as relações familiares, acompanhado do medo de que alguém, por maldade ou inadvertência, revele à criança ou adolescente a sua origem.

É universalmente reconhecido que as adoções bem-sucedidas são aquelas em que os filhos adotivos conhecem suas origens desde o início e em que os pais são capazes de falar livremente sobre o fato. ${ }^{185}$

Neste contexto, os interessados em adotar uma criança ou adolescente devem ser instruídos e orientados sobre a importância da transparência com relação à verdade biológica. É preciso que os adotantes tenham ciência de que a filiação adotiva, ainda que goze das mesmas prerrogativas da filiação biológica, possui algumas peculiaridades que devem ser observadas, sob pena de se acarretar prejuízo ao pleno desenvolvimento do adotando.

Os adotantes precisam entender que a manutenção de um relacionamento aberto e transparente com seus filhos será capaz de criar uma base sólida, incapaz de ser abalada pela vontade do adotado de conhecer as suas origens.

Nos termos dos ensinamentos de Sávio Renato Bittencourt Soares Silva:

É natural que adolescentes adotivos tenham curiosidade sobre sua história e desejem conhecer seus pais biológicos, saber se tiveram outros irmãos de sangue, entre outras coisas. Este fato traz uma dose de insegurança para o pai adotivo, que se sente um pouco desconfortável com a possibilidade de uma certa concorrência afetiva com a família natural. Reafirmo que a criança ou o adolescente tem direito à verdade. Não há motivos para se temer a perda do amor do filho em razão do simples encontro dele com os seus genitores, se isto for factualmente possível. O que foi semeado jamais se perderá, porque as sementes do amor, regadas pelo cuidado de pai, são indestrutíveis. Dê a seu filho a oportunidade do encontro com a sua história, sem chantagens ou chiliques. Fique a postos para atendê-lo neste momento em que sacia sua vontade de esgotar uma grande interrogação na sua imaginação. Na totalidade dos casos que acompanhei, este encontro não gerou danos psicológicos. Em alguns casos o adolescente se sentiu desconfortável diante da situação de degradação da família biológica, ou da pobreza. Nada que possa afetar as bases sólidas que o amor e uma criação responsável constituíram naquela personalidade de filho muito amado. ${ }^{186}$

185 BECKER, Maria Josefina. Da Adoção. In CURY, Munir. Estatuto da Criança e do Adolescente Comentado. Comentários Jurídicos e Sociais. 12a ed. São Paulo: Malheiros, 2013. pp. 221-222.

${ }^{186}$ SILVA, Sávio Renato Bittencourt Soares. Guia do Pai Adotivo. Orientações para uma Adoção Feliz. $2^{\mathrm{a}}$ ed. Curitiba: Juruá, 2012. p. 89. 
Feitas estas considerações, é possível perceber que o processo de adoção, da mesma forma que a filiação adotiva, possui características próprias, que devem ser conhecidas previamente pelos interessados (adotantes, adotandos e pais biológicos), a fim de que façam uma escolha consciente por esta forma de paternidade/filiação.

A edição da Lei n.12.010/2009 trouxe importantes modificações ao Estatuto da Criança e do Adolescente (vistas neste item), com o intuito de preservar, da forma mais ampla possível, os direitos das pessoas em desenvolvimento, garantindo-lhes o direito à convivência no seio de sua família natural, como regra, ou de sua família substituta, sob as modalidades da guarda, tutela ou adoção.

\subsection{Características dos adotantes, dos adotados e dos pais biológicos}

De acordo com o Estatuto da Criança e do Adolescente, podem adotar os maiores de 18 anos, casados ou solteiros, desde que sejam dezesseis anos mais velhos que os adotandos. Para a adoção conjunta, entretanto, diz a lei ser necessário que os adotantes sejam casados ou vivam em união estável, sendo vedada a adoção por descendentes ou por irmãos.

Em razão de a lei estabelecer que a adoção conjunta deve ser feita por pessoas casadas ou que vivam em união estável, parte da doutrina defende não ser possível a adoção por casais formados por pessoas do mesmo sexo, mais conhecidas como adoções homoafetivas. ${ }^{187}$

\footnotetext{
${ }^{187}$ Sobre o assunto, conferir FONSECA, Antônio Cezar Lima da. Direitos da Criança e do Adolescente. $2^{\mathrm{a}}$ ed. São Paulo: Atlas, 2012. pp. 145-146: "Não há regra legal dispondo a respeito da adoção por homossexual, masculino ou feminino, embora houvesse regramento dispondo que a mesma pessoa não podia ser adotada por duas outras, exceto se estas forem marido e mulher ou viverem em união estável, tal como constava no art. 1.622 do CC/02 e no art. 370 do CC/02. O art. 42, § 2 do ECA, mesmo com a redação da Lei 12.010/09, parece ter seguido essa orientação ao dispor: Para adoção conjunta, é indispensável que os adotantes sejam casados civilmente ou mantenham união estável, comprovada a estabilidade da família. A opção sexual ou o sexo do adotante não está em consideração por ocasião do ato de adoção, pelo que, vivendo ou não em união estável, nada impede a adoção por homossexual. Afinal, "o direito dos homossexuais de serem pais e mães, no âmbito dos direitos fundamentais, não encontra óbices, encontrando-se 'garantido pelos princípios da igualdade, do pluralismo e da não discriminação, sendo um direito inerente a todo ser humano, inspirado no respeito à dignidade humana e na sua condição de cidadão'. Há posicionamentos contrários e favoráveis a essas adoções, na doutrina e na jurisprudência. Os posicionamentos contrários olvidam-se de que adoção está para atender o melhor interesse da criança ou adolescente e não para satisfazer mazelas discriminatórias. Parece-nos possível essa adoção, desde que haja vantagem à criança e ao adolescente, uma vez que é preferível uma criança ou adolescente abrigada em um lar e mantida com amor, do que jogada e abandonada nos semáforos do país (...)".
} 
Com o intuito de contornar esta vedação legal, muitas pessoas, apesar de manterem uma relação homoafetiva, formulavam pedido individual de adoção, ignorando o Poder Judiciário a existência do outro companheiro (ou companheira), que participará de forma ativa da criação do adotando.

A solução dada pelos interessados ao problema, porém, não atende aos interesses da criança. Isto porque, é mais adequado que o casal seja avaliado de forma conjunta, a fim de que a equipe interprofissional analise a estabilidade da relação homoafetiva e o ambiente familiar que os interessados podem proporcionar à criança. Ademais, sendo a adoção conjunta, as crianças estarão resguardadas na hipótese de eventual separação ou falecimento de um dos adotantes.

Frise-se que a adoção homoafetiva, atualmente, não encontra nenhum óbice em nosso sistema jurídico, quer porque as uniões homoafetivas foram reconhecidas pela Constituição Federal e pelo Supremo Tribunal Federal como entidade familiar ${ }^{188}$, quer

1881. ARGUIÇÃO DE DESCUMPRIMENTO DE PRECEITO FUNDAMENTAL (ADPF). PERDA PARCIAL DE OBJETO. RECEBIMENTO, NA PARTE REMANESCENTE, COMO AÇÃO DIRETA DE INCONSTITUCIONALIDADE. UNIÃO HOMOAFETIVA E SEU RECONHECIMENTO COMO INSTITUTO JURÍDICO. CONVERGÊNCIA DE OBJETOS ENTRE AÇÕES DE NATUREZA ABSTRATA. JULGAMENTO CONJUNTO. Encampação dos fundamentos da ADPF n ${ }^{\circ} 132-R J$ pela ADI $n^{\circ}$ 4.277-DF, com a finalidade de conferir "interpretação conforme à Constituição" ao art. 1.723 do Código Civil. Atendimento das condições da ação. 2. PROIBIÇÃO DE DISCRIMINAÇÃO DAS PESSOAS EM RAZÃO DO SEXO, SEJA NO PLANO DA DICOTOMIA HOMEM/MULHER (GÊNERO), SEJA NO PLANO DA ORIENTAÇÃO SEXUAL DE CADA QUAL DELES. A PROIBIÇÃO DO PRECONCEITO COMO CAPÍTULO DO CONSTITUCIONALISMO FRATERNAL. HOMENAGEM AO PLURALISMO COMO VALOR SÓCIO-POLÍTICO-CULTURAL. LIBERDADE PARA DISPOR DA PRÓPRIA SEXUALIDADE, INSERIDA NA CATEGORIA DOS DIREITOS FUNDAMENTAIS DO INDIVÍDUO, EXPRESSÃO QUE É DA AUTONOMIA DE VONTADE. DIREITO À INTIMIDADE E À VIDA PRIVADA. CLÁUSULA PÉTREA. O sexo das pessoas, salvo disposição constitucional expressa ou implícita em sentido contrário, não se presta como fator de desigualação jurídica (...). 3. TRATAMENTO CONSTITUCIONAL DA INSTITUIÇÃO DA FAMÍLIA. RECONHECIMENTO DE QUE A CONSTITUIÇÃO FEDERAL NÃO EMPRESTA AO SUBSTANTIVO "FAMÍLIA" NENHUM SIGNIFICADO ORTODOXO OU DA PRÓPRIA TÉCNICA JURÍDICA. A FAMÍLIA COMO CATEGORIA SÓCIO-CULTURAL E PRINCÍPIO ESPIRITUAL. DIREITO SUBJETIVO DE CONSTITUIR FAMÍLIA. INTERPRETAÇÃO NÃO-REDUCIONISTA. O caput do art. 226 confere à família, base da sociedade, especial proteção do Estado. Ênfase constitucional à instituição da família. Família em seu coloquial ou proverbial significado de núcleo doméstico, pouco importando se formal ou informalmente constituída, ou se integrada por casais heteroafetivos ou por pares homoafetivos. A Constituição de 1988, ao utilizar-se da expressão "família", não limita sua formação a casais heteroafetivos nem a formalidade cartorária, celebração civil ou liturgia religiosa. (...). 4. UNIÃO ESTÁVEL. NORMAÇÃO CONSTITUCIONAL REFERIDA A HOMEM E MULHER, MAS APENAS PARA ESPECIAL PROTEÇÃO DESTA ÚLTIMA. FOCADO PROPÓSITO CONSTITUCIONAL DE ESTABELECER RELAÇÕES JURÍDICAS HORIZONTAIS OU SEM HIERARQUIA ENTRE AS DUAS TIPOLOGIAS DO GÊNERO HUMANO. IDENTIDADE CONSTITUCIONAL DOS CONCEITOS DE "ENTIDADE FAMILIAR" E "FAMÍLIA". (...)5. DIVERGÊNCIAS LATERAIS QUANTO À FUNDAMENTAÇÃO DO ACÓRDÃO. Anotação de que os Ministros Ricardo Lewandowski, Gilmar Mendes e Cezar Peluso convergiram no particular entendimento da impossibilidade de ortodoxo 
porque esta modalidade de adoção, por si só, não é prejudicial aos interesses das crianças e adolescentes, principais sujeitos desta relação. Nesse sentido, aliás, merecem destaque os ensinamentos da doutrina:

\begin{abstract}
Ao estabelecer, como premissa, que as relações homoafetivas correspondem a uma entidade familiar, e como tal, são dignas da mesma proteção que o Estado dispensa as famílias formadas pelo casamento ou união estável heteroafetiva, então não haverá impedimento legal para que essa entidade familiar possa adotar.

E para exercício do direito, somente se poderá exigir do casal homoafetivo o mesmo que se puder exigir dos casais heterossexuais por força das previsões do ordenamento, inclusive, a estabilidade da família.

Ou será que podemos dizer que a orientação sexual é fator relevante para a viabilidade da adoção? Convém lembrar que a adoção singular- realizada por uma única pessoa, homem ou mulher- não perscruta nem encontra óbice na orientação sexual do pretenso adotante. Não se indaga, nem se poderia fazê-lo sem negar vigência à Constituição Federal, se o interessado em adotar é heterossexual.

Entender que os companheiros afetivos do mesmo sexo merecem menos que aqueles conviventes de sexo diferente, tão somente porque não protagonizam uma relação heterossexual, tem uma designação inescusável: chama-se preconceito.

(...)

Não parecem existir razões de ordem científica para recusar aos casais homoafetivos a possibilidade de adoção, da mesma forma que é absolutamente incogitável impedir que homossexuais possam gerar naturalmente com o sexo oposto. Não há proibição de serem pais consanguíneos, muito menos civis. Não será a orientação sexual que fará de homens e mulheres pais melhores ou piores. ${ }^{189}$
\end{abstract}

Atento a esta realidade e à necessidade de conformação do direito posto com a realidade e as necessidades sociais, o Superior Tribunal de Justiça reconheceu a possibilidade de adoção por casais homossexuais, deixando claro que os diversos estudos sobre o tema demonstram não haver nenhum prejuízo ao desenvolvimento de crianças adotadas por pessoas do mesmo sexo. Em razão da relevância do tema e do pioneirismo da decisão, transcreve-se abaixo a ementa integral do acórdão:

enquadramento da união homoafetiva nas espécies de família constitucionalmente estabelecidas. Sem embargo, reconheceram a união entre parceiros do mesmo sexo como uma nova forma de entidade familiar. Matéria aberta à conformação legislativa, sem prejuízo do reconhecimento da imediata auto-aplicabilidade da Constituição. 6. INTERPRETAÇÃO DO ART. 1.723 DO CÓDIGO CIVIL EM CONFORMIDADE COM A CONSTITUIÇÃO FEDERAL (TÉCNICA DA "INTERPRETAÇÃO CONFORME"). RECONHECIMENTO DA UNIÃO HOMOAFETIVA COMO FAMÍLIA. PROCEDÊNCIA DAS AÇÕES. Ante a possibilidade de interpretação em sentido preconceituoso ou discriminatório do art. 1.723 do Código Civil, não resolúvel à luz dele próprio, faz-se necessária a utilização da técnica de "interpretação conforme à Constituição". Isso para excluir do dispositivo em causa qualquer significado que impeça o reconhecimento da união contínua, pública e duradoura entre pessoas do mesmo sexo como família. Reconhecimento que é de ser feito segundo as mesmas regras e com as mesmas consequências da união estável heteroafetiva. (ADI 4277, Relator(a): Min. AYRES BRITTO, Tribunal Pleno, julgado em 05/05/2011, DJe-198 DIVULG 13-10-2011 PUBLIC 14-10-2011 EMENT VOL-02607-03 PP-00341 RTJ VOL-00219- PP-00212).

${ }^{189}$ RIBEIRO, Paulo Hermano Soares; SANTOS, Vívian Cristina Maria; SOUZA, Ionete de Magalhães. Nova Lei de Adoção Comentada. $2^{\mathrm{a}}$ ed. Leme: J.H.Mizuno, 2012. pp. 40-50. 
DIREITO CIVIL. FAMÍLIA. ADOÇÃO DE MENORES POR CASAL HOMOSSEXUAL. SITUAÇÃO JÁ CONSOLIDADA. ESTABILIDADE DA FAMÍLIA. PRESENÇA DE FORTES VÍNCULOS AFETIVOS ENTRE OS MENORES E A REQUERENTE. IMPRESCINDIBILIDADE DA PREVALÊNCIA DOS INTERESSES DOS MENORES. RELATÓRIO DA ASSISTENTE SOCIAL FAVORÁVEL AO PEDIDO. REAIS VANTAGENS PARA OS ADOTANDOS. ARTIGOS $1^{\circ}$ DA LEI 12.010/09 E 43 DO ESTATUTO DA CRIANÇA E DO ADOLESCENTE. DEFERIMENTO DA MEDIDA.

1. A questão diz respeito à possibilidade de adoção de crianças por parte de requerente que vive em união homoafetiva com companheira que antes já adotara os mesmos filhos, circunstância a particularizar o caso em julgamento.

2. Em um mundo pós-moderno de velocidade instantânea da informação, sem fronteiras ou barreiras, sobretudo as culturais e as relativas aos costumes, onde a sociedade transforma-se velozmente, a interpretação da lei deve levar em conta, sempre que possível, os postulados maiores do direito universal.

3. O artigo $1^{\circ}$ da Lei $12.010 / 09$ prevê a "garantia do direito à convivência familiar a todas e crianças e adolescentes". Por sua vez, o artigo 43 do ECA estabelece que "a adoção será deferida quando apresentar reais vantagens para o adotando e fundar-se em motivos legítimos".

4. Mister observar a imprescindibilidade da prevalência dos interesses dos menores sobre quaisquer outros, até porque está em jogo o próprio direito de filiação, do qual decorrem as mais diversas consequências que refletem por toda a vida de qualquer indivíduo.

5. A matéria relativa à possibilidade de adoção de menores por casais homossexuais vincula-se obrigatoriamente à necessidade de verificar qual é a melhor solução a ser dada para a proteção dos direitos das crianças, pois são questões indissociáveis entre si.

6. Os diversos e respeitados estudos especializados sobre o tema, fundados em fortes bases científicas (realizados na Universidade de Virgínia, na Universidade de Valência, na Academia Americana de Pediatria), "não indicam qualquer inconveniente em que crianças sejam adotadas por casais homossexuais, mais importando a qualidade do vínculo e do afeto que permeia o meio familiar em que serão inseridas e que as liga a seus cuidadores".

7. Existência de consistente relatório social elaborado por assistente social favorável ao pedido da requerente, ante a constatação da estabilidade da família. Acórdão que se posiciona a favor do pedido, bem como parecer do Ministério Público Federal pelo acolhimento da tese autoral.

8. É incontroverso que existem fortes vínculos afetivos entre a recorrida e os menores - sendo a afetividade o aspecto preponderante a ser sopesado numa situação como a que ora se coloca em julgamento.

9. Se os estudos científicos não sinalizam qualquer prejuízo de qualquer natureza para as crianças, se elas vêm sendo criadas com amor e se cabe ao Estado, ao mesmo tempo, assegurar seus direitos, o deferimento da adoção é medida que se impõe.

10. O Judiciário não pode fechar os olhos para a realidade fenomênica. Vale dizer, no plano da "realidade", são ambas, a requerente e sua companheira, responsáveis pela criação e educação dos dois infantes, de modo que a elas, solidariamente, compete a responsabilidade.

11. Não se pode olvidar que se trata de situação fática consolidada, pois as crianças já chamam as duas mulheres de mães e são cuidadas por ambas como filhos. Existe dupla maternidade desde o nascimento das crianças, e não houve qualquer prejuízo em suas criações.

12. Com o deferimento da adoção, fica preservado o direito de convívio dos filhos com a requerente no caso de separação ou falecimento de sua companheira. Asseguram-se os direitos relativos a alimentos e sucessão, viabilizando-se, ainda, a inclusão dos adotandos em convênios de saúde da requerente e no ensino básico e superior, por ela ser professora universitária. 
13. A adoção, antes de mais nada, representa um ato de amor, desprendimento. Quando efetivada com o objetivo de atender aos interesses do menor, é um gesto de humanidade. Hipótese em que ainda se foi além, pretendendo-se a adoção de dois menores, irmãos biológicos, quando, segundo dados do Conselho Nacional de Justiça, que criou, em 29 de abril de 2008, o Cadastro Nacional de Adoção, $86 \%$ das pessoas que desejavam adotar limitavam sua intenção a apenas uma criança.

14. Por qualquer ângulo que se analise a questão, seja em relação à situação fática consolidada, seja no tocante à expressa previsão legal de primazia à proteção integral das crianças, chega-se à conclusão de que, no caso dos autos, há mais do que reais vantagens para os adotandos, conforme preceitua o artigo 43 do ECA. Na verdade, ocorrerá verdadeiro prejuízo aos menores caso não deferida a medida.

15. Recurso especial improvido.

(REsp 889.852/RS, Rel. Ministro LUIS FELIPE SALOMÃO, QUARTA TURMA, julgado em 27/04/2010, DJe 10/08/2010) (grifos no original)

Além dos requisitos objetivos para a adoção, acima estudados, o Estatuto da Criança e do Adolescente, em seus artigos 29 e 50, $\S 2^{\circ}$ estabelece que os interessados devem ter condições de oferecer um ambiente familiar adequado e que a medida há de representar real vantagem aos interesses do adotando.

Como bem lembrado por Maria Josefina Becker, ${ }^{190}$ quando o Estatuto da Criança e do Adolescente fala em ambiente familiar adequado, "deve ficar claro que se está falando em adequação àquela criança de cuja colocação se está tratando, e isso inclui aspectos afetivos, disponibilidade e desejo de proteger, mais do que recursos materiais e financeiros".

As exigências legais objetivas e subjetivas aqui mencionadas acabam por delinear, ainda que parcialmente, o perfil dos adotantes brasileiros. Afinal, mesmo que assim o desejasse, o menor de 18 anos ou a pessoa com comportamento degradante, por exemplo, não poderia adotar em razão de expressa vedação legal.

Estes requisitos, porém, são insuficientes- por si sós- para determinar, com precisão, o perfil dos adotantes brasileiros, quer por serem extremamente genéricos, quer por não conseguirem abarcar as expectativas dos interessados e os seus desejos mais íntimos.

190 BECKER, Maria Josefina. Da Adoção. In CURY, Munir. Estatuto da Criança e do Adolescente Comentado. Comentários Jurídicos e Sociais. 12a ed. São Paulo: Malheiros, 2013. p. 155. 
A Associação dos Magistrados Brasileiros (AMB), em pesquisa realizada pelo método da telepesquisa, de 10 a 27 de abril de $\underline{\mathbf{2 0 0 8}}$, com o objetivo de verificar o grau de consciência e envolvimento da população com o tema da adoção, medir o nível de interesse versus rejeição quanto à medida e identificar fatores que afetam ou limitam ações proativas no apoio a crianças abrigadas, traçou o perfil dos adotantes brasileiros, de acordo com as categorias a seguir expostas: ${ }^{191}$

(1) idade dos pretendentes: $30,1 \%$ entre 25 a 29 anos; $23,8 \%$ entre 30 a 39 anos; $20,5 \%$ entre 40 a 49 anos e $25,5 \%$ de 50 ou mais;

(2) renda familiar dos pretendentes: $20,1 \%$ se recusaram a informar; $0,8 \%$ não possui rendimentos; 7,9\% possuem renda superior a $\mathrm{R} \$ 7.500,00$ (sete mil e quinhentos reais); 5,0\% possuem renda de $\mathrm{R} \$ 6.000,00$ (seis mil reais) a $\mathrm{R} \$ 7.500,00$ (sete mil e quinhentos reais); 7,9\% possuem renda entre $\mathrm{R} \$ 4.000,00$ (quatro mil reais) e $\mathrm{R} \$ 6.000,00$ (seis mil reais); 15,9\% possuem renda de $\mathrm{R} \$ 2.000,00$ (dois mil reais) a $\mathrm{R} \$ 4.000,00$ (quatro mil reais); $25,9 \%$ possuem renda de $\mathrm{R} \$ 750,00$ (setecentos e cinquenta reais) a $\mathrm{R} \$$ $2.000,00$ (dois mil reais) e 16,3\% possuem renda até $\mathrm{R} \$ 750,00$ (setecentos e cinquenta reais);

(3) estado civil dos pretendentes: $58 \%$ de casados, 28,2\% de solteiros, 5,5\% de separados/divorciados, $5,0 \%$ de pessoas que vivem em união estável, 1,7\% de viúvos e $0,8 \%$ se recusou a prestar esta informação;

(4) perfil da criança que o pretendente adotaria: (a) com relação à idade: $18,7 \%$ adotariam crianças de qualquer idade; $1,1 \%$ adotariam crianças acima de 12 anos; 2,7\% adotariam crianças de 9 a 12 anos; 3,4\% adotariam crianças de 6 a 9 anos; 13,7\% adotariam crianças de 3 a 6 anos; 28,2\% adotariam crianças de 6 meses a 3 anos e 32,1\% adotariam crianças entre 0 e 6 meses; (b) com relação ao sexo: 27,0\% preferem adotar meninas, 9,5\% adotariam meninos e 63,5\% não possuem preferência; (c) com relação à cor ou raça: 79,6\% não possuem preferência; 7,6\% adotariam crianças brancas; 3,8\% preferem crianças negras; $3,1 \%$ recusaram-se a informar; $3,1 \%$ adotariam crianças mulatas e 2,8\% adotariam crianças de outras raças (que não sejam brancas ou negras) e (d) crianças

${ }^{191}$ Dados obtidos da obra de Simone Franzoni Bochnia. Da Adoção. Categorias, Paradigmas e Práticas de Direito de Família. Curitiba: Juruá, 2010. pp. 178-179. 
portadoras de necessidades especiais: $35,0 \%$ dos candidatos afirmaram que não adotariam, $54,9 \%$ afirmaram que adotariam e $10,1 \%$ recusaram-se a informar.

Em setembro de 2011, o Conselho Nacional de Justiça informou, com base nos dados do Cadastro Nacional de Adoção, que (1) existiam 4.760 crianças disponíveis para adoção; (2) 27.478 interessados foram cadastrados até agosto do mencionado ano; (3) apenas 538 pessoas declararam aceitar crianças apenas de raça negra; (4) 10.173 pessoas declararam aceitar crianças apenas de raça branca; (5) 1.537 pretendentes manifestaram interesse em adotar crianças pardas; (6) 9.137 pessoas se mostraram indiferentes à raça da criança; (7) muitos pretendentes declararam não ter interesse em adotar irmãos, apesar de existirem 3.749 irmãos disponíveis para adoção e (8) as crianças disponíveis à adoção se subdividem, de acordo com a raça, da seguinte maneira: 2.230 pardos, 1.656 brancos, 907 negros, 35 amarelos e 28 indígenas. ${ }^{192}$

A leitura das conclusões das pesquisas realizadas pela Associação dos Magistrados Brasileiros- AMB pelo Conselho Nacional de Justiça- CNJ demonstra que o perfil dos adotantes vem sofrendo sensíveis modificações nos últimos anos, em especial para admitir as adoções tardias, inter-raciais e de crianças com deficiências (denominadas de adoções necessárias).

A prova deste fato está no estudo realizado pela psicóloga Lidia Natalia Dobrianskyj Weber, ${ }^{193}$ em $\underline{\mathbf{2 0 0 4}}$, com as seguintes conclusões: 1) a maioria dos adotantes (63\%) adotou uma criança para resolver uma necessidade na sua vida: não pôde gerar filhos genéticos, ainda era solteiro ou um filho seu era falecido; 2) $96 \%$ das mães e $86 \%$ dos pais que adotaram eram brancos; 3) a maioria absoluta (71\%) adotou uma criança de cor branca, 24\% adotaram uma criança de cor parda; 5\% adotaram uma criança de cor negra e $0,5 \%$ adotou uma criança de cor amarela. Como a adoção de uma criança mestiça por adotantes brancos é considerada inter-racial, houve $28 \%$ de adoções inter-raciais, se for considerada a cor da pele da mãe e $26 \%$, se for considerada a cor da pele do pai; desse total de adoções inter-raciais, somente $4 \%$ foram de adotantes brancos e crianças negras; 4) $28 \%$

\footnotetext{
${ }^{192}$ Informações obtidas junto ao site do Conselho Nacional de Justiça: http://www.cnj.jus.br/noticias.

${ }^{193}$ WEBER, Lidia Natalia Dobrianskyj. Aspectos Psicológicos das Famílias por Adoção. In LEITE, Eduardo de Oliveira (org.). Grandes Temas da Atualidade: Adoção. Aspectos Jurídicos e Metajurídicos. Rio de Janeiro: Forense, 2005. pp. 226-229.
} 
dos pais afirmaram que uma criança pode ser adotada com qualquer idade, mas sua exigência era um bebê com até três meses de idade.

Embora as pesquisas acima citadas possuam objetivos diversos, alguns itens abordados, como a preferência pela idade e pela raça da criança, são idênticos e demonstram uma alteração nas expectativas dos adotantes, muito provavelmente em razão do serviço realizado pelos Grupos de Apoio à Adoção.

Conforme se percebe pela leitura dos dados obtidos pelo Conselho Nacional de Justiça, a grande maioria das crianças disponíveis para adoção não é branca.

Apesar da abertura ocorrida nos últimos anos, os interessados (na maioria, brancos) ainda preferem adotar crianças brancas, saudáveis e de tenra idade. ${ }^{194}$ Dessa maneira, ainda que as pesquisas não fossem claras, este fato, aliado à condição de pobreza, discriminação e violência dos negros brasileiros, permitiria a conclusão de que a grande maioria das crianças disponíveis para adoção é negra (no sentido lato) e maior de três anos. ${ }^{195}$

Ademais, levando-se em consideração que a adoção depende da destituição do poder familiar ou da concordância dos pais biológicos, pode-se afirmar que as crianças abrigadas, quase sempre, são fruto de relações familiares desestruturadas, muitas vezes marcadas pela violência física e psíquica. Esta realidade, como regra, delineia o perfil

194 Conforme bem lembrado pela professora da Universidade de Harvard, Elizabeth Bartholet (BARTHOLET, Elizabeth. Where do Black children belong? The politics of race matching in adoption. University of Pennsylvania Law Review, n. 05, vol. 139, p. 1166, may 1991), "The familiar refrain that there is no children available for adoption is a reflection of the racial policies of many adoption agencies and the racial preferences of many adoptive parents. The reality is that there are very few white children by comparison to the large pool of would-be white adopters. But there are many non-white children available to this pool, both through independent adoption in this country and through international adoption. And there are many non-white children waiting in foster care who are unavailable solely because of adoption agency insistence that they not be placed transracially" ("A afirmação de que não existem crianças disponíveis para adoção é um reflexo das políticas raciais de muitas agências de adoção e das preferências raciais de muitos pais adotivos. A realidade é que existem pouquíssimas crianças brancas em comparação com o grande número de pretensos adotantes brancos. Mas existem muitas crianças não brancas disponíveis, tanto para as adoções internas quanto internacionais. E existem muitas crianças não brancas aguardando em instituições, que estão disponíveis somente em razão da insistência das agências de adoção em não efetivar adoções transraciais").

${ }^{195}$ Nas palavras de Simone Franzoni Bochnia: "Sabe-se que o Brasil é um país de típica miscigenação de negros, pardos, índios e brancos, e estes são os nossos filhos abandonados e institucionalizados, características que muitas vezes não correspondem às desejadas pelos casais pretendentes" (BOCHNIA, Simone Franzoni. Da Adoção. Categorias, Paradigmas e Práticas do Direito de Família. Curitiba: Juruá, 2010. p. 190). 
psicológico dos adotandos e é responsável pelas dificuldades enfrentadas pelos adotantes no estabelecimento e na manutenção do vínculo afetivo com a criança.

Por fim, e não menos importante, deve ser analisado o perfil dos pais biológicos das crianças colocadas para adoção. Raros são os estudos que se dedicam a este tema.

Conforme já mencionado acima, o sistema jurídico nacional exige que o Poder Público se valha de todos os meios disponíveis para a manutenção da criança em sua família biológica, através do restabelecimento dos vínculos afetivos, sendo a adoção uma medida excepcional.

Dessa maneira, a análise do perfil dos pais biológicos do adotando possibilita que o magistrado avalie se a adoção é, de fato, a medida mais adequada ao caso concreto. Caso reste comprovado que os motivos que levaram ao abandono da criança ou à suspensão do poder familiar não mais persistem, o juiz tem o dever de fomentar a permanência da mesma com sua família de origem.

Se, entretanto, as condições que levaram ao abrigamento persistirem, alternativa não restará ao Poder Judiciário senão a colocação da criança em família substituta, nas modalidades de tutela, guarda ou adoção.

De acordo com o disposto no artigo45, $\S 1^{\mathrm{o}}$ do Estatuto da Criança e do Adolescente, caso não haja concordância dos pais da criança, a adoção pressupõe a destituição do poder familiar, a ser declarada em processo judicial, permeado pelos princípios do contraditório e da ampla defesa, e instaurado por provocação do Ministério Público ou de parentes do infante.

As hipóteses de suspensão ou perda do poder familiar estão previstas nos artigos 1.637 e 1.638 do Código Civil e no artigo 22 do Estatuto da Criança e do Adolescente, que prevê as obrigações inerentes ao poder familiar, nos seguintes termos:

Artigo 1.637. Se o pai, ou a mãe, abusar de sua autoridade, faltando aos deveres a ele inerentes ou arruinando os bens dos filhos, cabe ao juiz, requerendo algum parente, ou o Ministério Público, adotar a medida que lhe pareça reclamada pela segurança do menor e seus haveres, até suspendendo o poder familiar, quando convenha. 
Parágrafo único: Suspende-se igualmente o exercício do poder familiar ao pai ou à mãe condenados por sentença irrecorrível, em virtude de crime cuja pena exceda a dois anos de prisão.

Artigo 1.638. Perderá por ato judicial o poder familiar o pai ou a mãe que:

I- castigar imoderadamente o filho

II- deixar o filho em abandono;

III- praticar atos contrários à moral e aos bons costumes;

IV-incidir, reiteradamente, nas faltas previstas no artigo antecedente.

Artigo 22. Aos pais incumbe o dever de sustento, guarda e educação dos filhos menores, cabendo-lhes, ainda, no interesse destes, a obrigação de cumprir e fazer cumprir as determinações judiciais.

A leitura dos dispositivos legais que tratam do tema demonstra que a perda ou a suspensão do poder familiar pressupõe a prática de ato praticado intencionalmente pelos genitores, por negligência ou omissão, contrário ao bem-estar e ao melhor interesse dos filhos.

Resta claro, assim, que os processos de destituição do poder familiar possuem como objetivo a preservação dos interesses da criança, sujeito em desenvolvimento, devendo as suas causas ser investigadas e analisadas por equipe interprofissional.

Sendo assim, na maioria das vezes, os pais biológicos das crianças entregues à adoção ou desvinculadas do poder familiar são pessoas despreparadas para a paternidade, por demonstrarem um comportamento inadequado e a incapacidade de zelar pelos interesses dos filhos.

As pesquisas aqui estudadas, entretanto, não trazem estatísticas sobre as características dos pais biológicos das crianças disponíveis para adoção, faltando dados empíricos para a delimitação de um perfil detalhado destas pessoas, considerando-se a sua idade, sua raça e as causas que levaram à destituição do poder familiar.

Conforme acima mencionado, a única informação que se tem quanto ao perfil destes pais biológicos está vinculada às causas do abrigamento de crianças e adolescentes, apuradas por Sávio Bittencourt, ${ }^{196}$ junto ao Instituto de Pesquisa Econômica AplicadaIPEA. Os dados desta pesquisa demonstram que os pais naturais deixam seus filhos em abrigos (ou estas crianças são para lá dirigidas), em virtude de ausência de recursos

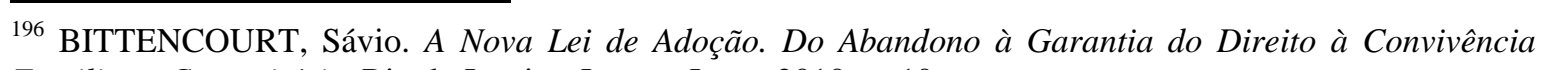
Familiar e Comunitária. Rio de Janeiro: Lumen Jures, 2010. p. 10. 
materiais, dependência química, vivência de rua, encarceramento, deficiências, puro abandono, dentre outras causas.

Estes dados apenas confirmam (1) que estes pais não possuem condições de cuidar de seus filhos, quer porque precisam- antes de mais- se tratar e estruturar a própria vida, quer por total ausência de interesse na paternidade e (2) que as pesquisas disponíveis não trazem um perfil detalhado destas pessoas.

Ressalte-se, porém, que a entrega de um filho à adoção, ainda quando os pais biológicos não vêem alternativa, representa uma escolha difícil, que causa para alguns uma sensação de culpa por toda a vida. Em razão disso, é importante que o Estado propicie acompanhamento psicológico a estes pais, como forma de amenizar-lhes o sofrimento.

No Brasil, conforme visto acima, o adotado tem o direito de buscar os seus pais biológicos quando completa dezoito anos. A lei, porém, não admite que os pais biológicos tenham acesso ao paradeiro do filho que entregaram à adoção (voluntariamente ou não, nas hipóteses de destituição familiar). Parece que a abertura da adoção é uma via de mão única, estabelecida somente no interesse da criança.

Nos Estados Unidos, a abertura da adoção vem sendo defendida nos últimos anos e tem como fundamento não apenas os interesses do adotado, como também do adotante e dos pais biológicos. ${ }^{197}$

\footnotetext{
197 "Until very recently, adopted children when reaching adulthood had no way of finding their biological parents. Today adoption professionals are generally supportive of giving adoptees access to records holding details of their genealogical and biological past and information necessary to pursue reunion with their biological parents if they had made known their availability for contact. (...) The call for continuing access is based on two distinct developments in adoption practice. First, many professionals have expressed a concern about adoptees' heightened identity confusion in adolescence arising from the secrecy attached to information about the past and have advocated openness as a way of ameliorating this confusion. Second, continuing contact is more common because the decreasing availability of adoptable infants has bolstered the involvement of the birthmother in adoption decision making and practice. AS the number of infants in adoption has decreased over the past three decades, the influence and control of birthparents in the adoption process has increased dramatically. In independent adoptions, which have flourished in the recent past, attorneys and agencies have strengthened the role of the birthmother in the adoption process, allowing her to participate in the selection of the adoptive parents and supporting requests that she be allowed continuing access to the adopted child" "Até muito recentemente, as crianças adotadas, até atingirem a maioridade, não tinham meios de encontrar os seus pais biológicos. Hoje, entretanto, os profissionais que trabalham com adoção são, como regra, favoráveis a fornecer aos adotados acesso aos bancos de dados que armazenam detalhes do seu passado biológico e genealógico, além de informações necessárias à localização de seus pais biológicos, caso eles tenham deixado dados para contato. (...) Este pleito pelo acesso contínuo é baseado em dois distintos aspectos da experiência da adoção. Primeiramente, muitos profissionais expressaram preocupação pela confusão na formação da identidade dos adotados, ocasionada pelo segredo com relação às
} 
De acordo com Annete Baran e Reuben Pannor, ${ }^{198}$

O abandono de uma criança pequena pode ser extremamente prejudicial aos pais
biológicos e causar-lhes sofrimento e dor por toda a vida. Mesmo quando a
entrega da criança é fruto de uma decisão cuidadosamente tomada, mães
biológicas- e frequentemente pais biológicos- podem sofrer de um imenso senso
de desvalia. É possível que eles se sintam culpados por sua conduta. Estes pais
podem acreditar que seus filhos não entenderão as causas desta conduta e culpá-
los e odiá-los por abandoná-los. Os pais biológicos podem querer que seus filhos
saibam que eles ainda se importam com seu bem-estar e, ademais, podem querer
saber que espécie de pessoa seus filhos se tornaram. Independentemente da
quantidade de filhos que os pais naturais tiverem após a adoção, é possível que
queiram manter contato com aquele filho do qual desistiram. Nas adoções
tradicionais fechadas, este contato não é possível. Os pais biológicos não sabem
quem adotou o seu filho, onde ele vive ou, até mesmo, se ele ainda é vivo (...).

A defesa da abertura da adoção, entretanto, encontra resistência até mesmo na doutrina norte-americana. Alguns pesquisadores entendem que o contato entre os envolvidos pode (1) impedir que a criança forme laços de afeto com os adotantes; (2) criar prejuízos à formação da identidade do adotado, especialmente quando ele é pequeno; (3) desestimular a adoção por casais que preferem o anonimato e (4) impedir que os pais biológicos superem o desligamento de seus filhos. ${ }^{199}$

informações de seu passado, e passaram a defender a abertura como forma de amenizar esta confusão. Ademais, a manutenção do contato é mais comum em razão da diminuição do número de crianças disponíveis para adoção e da participação da mãe biológica na tomada de decisões a respeito do assunto. Como o número de crianças disponíveis sofreu uma queda nas últimas três décadas, a influência e o controle exercidos no processo de adoção pelos pais biológicos aumentaram dramaticamente. Nas adoções independentes, que ganharam importância nos últimos anos, os advogados e agências permitiram que a mãe biológica desempenhasse um papel mais ativo no processo de adoção, admitindo, inclusive, que ela participasse da escolha dos pais adotivos e amparando-a nos pedidos de acesso ao filho"). (BERRY, Marianne. Risks and Benefits of Open Adoption. The Future of Children. Adoption, vol. 3, n.1, p. 126, Spring 1993).

198“"Relinquishment of a newborn child may be profoundly damaging to birthparents and cause lifelong pain and suffering. Even when relinquishment is carefully considered and chosen option, birthmothers- and often birthfathers - may suffer from a heightened sense of worthlessness after giving away a child. They may feel guilty about their actions. These birthparents may believe that their offspring will not understand the reasons for relinquishment and that these offspring will blame and hate their birthparents for rejecting and abandoning them. The birthparents may want their children to know that they continue to care about them and, in turn, may wish to know about the kind of people their children have become. No matter how many children they may have subsequently, birthparents may still desire knowledge and contact with the one they gave up. In traditional closed adoptions, such knowledge and contact is not possible. Birthparents do not know who adopted their child, where he or she lives, or even whether the child is alive or dead (...)" (BARAN, Anette; PANNOR, Reuben. Perspectives on Open Adoption. The Future of Children. Adoption, vol. 3, n.1, p. 120, Spring 1993).

${ }^{199}$ Conferir BERRY, Marianne. Risks and Benefits of Open Adoption. The Future of Children. Adoption, vol. 3, n.1, Spring 1993 e BARAN, Anette; PANNOR, Reuben. Perspectives on Open Adoption. The Future of Children. Adoption, vol. 3, n.1, Spring 1993. 
As vantagens e desvantagens da adoção aberta ainda não foram amplamente debatidas em nosso país, mas é bem provável que o Poder Judiciário logo seja instado a se manifestar sobre o direito dos pais biológicos de manterem contato com os filhos que foram entregues à adoção, em razão de interpretação analógica da lei vigente.

Seja como for, as consideração feitas neste item deixaram claro que, mesmo não havendo dados empíricos suficientes sobre todos os sujeitos envolvidos nos processos de adoção, é possível se afirmar que a delimitação do perfil destas pessoas permite que os advogados, os membros do Poder Judiciário, do Ministério Público, da Defensoria Pública e a equipe técnica multidisciplinar tratem dos problemas advindos da filiação afetiva de forma mais ampla e consciente, detectando os pontos vulneráveis da medida e estimulando a convivência familiar (no seio da família de origem ou da família substituta).

\subsection{Adoção inter-racial: argumentos contrários e favoráveis à medida}

Conforme visto no item acima, os adotantes- na grande maioria brancos- preferem adotar crianças que tenham características genéticas muito semelhantes às suas, resistindo às chamadas adoções inter-raciais. ${ }^{200}$

Apesar das estatísticas aqui apresentadas e dos riscos da institucionalização prolongada, a adoção inter-racial ainda não mereceu a devida atenção dos nossos juristas, psicólogos e assistentes sociais. Muito embora a medida tenha sido incentivada nos últimos anos, até mesmo em razão da experiência positiva de "celebridades" divulgada pela mídia, o tema não foi explorado em seus aspectos jurídicos e sociais.

\footnotetext{
${ }^{200}$ Como bem lembrado por BARTHOLET, Elizabeth. Where do Black children belong? The politics of race matching in adoption. University of Pennsylvania Law Review, n. 05, vol. 139, p. 1250, may 1991, "Many adoptive parents are infertile, and they turn to adoption only after discovering they cannot reproduce themselves biologically. It is understandable in this context that in adoption their first instinct would be to look for a biologic and racial look-alike. (...) They are simultaneously conditioned by a variety in forces in our society to think of biological parenting as preferable to adoptive parenting. All adoptions require parents to transcend this kind of conditioning. The evidence similarly indicates that when whites arrive at the point of consciously choosing transracial parenthood and enter into parenting relationships with black children, the relationships work, and indeed, appear to work as well as same-race biologic parenting relationships". ("Muitos pais adotivos são inférteis e buscam a adoção apenas após descobrir que não podem se reproduzir biologicamente. Neste contexto, é compreensível que eles procurem, de início, crianças da mesma raça que a sua. (...) Eles são condicionados por diversas forças de nossa sociedade a pensar que a paternidade biológica é preferível à paternidade adotiva. Entretanto, todas as adoções exigem que os interessados transcendam este tipo de condicionamento. As evidências demonstram que os pais adotivos são capazes de agir dessa forma e que as adoções transraciais dão certo. As evidências também indicam que, quando os interessados decidem adotar de forma transracial, os relacionamentos funcionam e, ademais, parecem ser tão exitosos quanto aqueles estabelecidos entre pessoas da mesma raça").
} 
Em razão da falta de produção científica nacional, com a finalidade de analisar as peculiaridades e os desafios da adoção inter-racial de forma adequada e abrangente, alternativa não há senão a consulta da literatura estrangeira, em especial das pesquisas e estudos realizados nos Estados Unidos (com as devidas adaptações para a realidade brasileira).

A adoção inter-racial nos Estados Unidos ganhou força com o final da Segunda Guerra Mundial (1945) e a ascensão do movimento dos direitos civis, na década de $60 .^{201}$ Em 1971, o país registrou o número de 2.574 adoções inter-raciais. ${ }^{202}$

Apesar de existirem vozes contrárias à adoção entre pessoas de raças diversas desde o início de sua prática, em 1948, a oposição ganhou força apenas em 1972, quando a The National Association of Black Social Workers (NABSW) declarou, publicamente, que a adoção inter-racial (transracial) representava um genocídio da identidade negra. Esta

${ }^{201}$ De acordo com os ensinamentos de BARTHOLET, Elizabeth. Where do Black children belong? The politics of race matching in adoption. University of Pennsylvania Law Review, n. 05, vol. 139, p. 1178, may 1991, "The 1960s represented a period of relative openness to transracial adoption. Foreign adoptions helped paved the way. In the aftermath of the Korean War, South Korea made many of its abandoned and orphaned children available for adoption. Large numbers of these were mixed race children who had been fathered by black American soldiers stationed in Korea. Adoption agencies and prospective parents looked increasingly to Korea and to Third World countries in a trend that has continued to this day. The children they brought here for adoption, many of whom had identifiably foreign features and dark skin, began to accustom people to the idea of adoptive families that involved mixed racial and ethnic backgrounds. The civil rights movement in the country brought increasing attention to the plight of the minority children, who had languished in the foster care system over the years. This movement's integrationist ideology made transracial adoption a sympathetic idea to many adoption workers and prospective parents. Tranracial adoption also served the needs of the waiting white parents, for whom there were not enough color-matched children available, as well as interests of the agencies in putting together adoptive families and reducing the foster care population. And so agencies began to place waiting black children with white parents when there were no black parents apparently available. The reported number of transracial placements rose gradually to 733 in 1968, and it more than tripled in the next three years, to reach a peak of 2574 in 1971". "Os anos 60 foram um período de relativa abertura para a adoção transracial. As adoções internacionais ajudaram a pavimentar o caminho. Após a guerra da Coréia, o Sul da Coréia colocou à disposição para adoção muitas de suas crianças abandonadas e órfãs. Um grande número destas crianças era de raça mista, que tinham sido geradas por soldados americanos negros. As agências de adoção e os pretensos pais passaram a olhar para a Coréia e para os países de terceiro mundo, em um hábito que permanece até os dias de hoje. As crianças que eles trouxeram ao país para adoção, muitas das quais possuíam traços estrangeiros e pela "escura", começaram a acostumar as pessoas com a ideia de famílias adotivas que envolviam uma mistura de raças e etnias. O movimento dos direitos civis neste país causou crescente atenção ao pleito das crianças que haviam permanecido em abrigos por anos. A ideologia integracionista do movimento fez da adoção transracial uma ideia atraente para muitos trabalhadores da área social e interessados na adoção. Ademais, a adoção transracial serviu aos interesses dos adotantes brancos, para quem não estava disponível um número suficiente de crianças da mesma raça, bem como aos interesses das agências em encontrar famílias adotivas às crianças disponíveis e diminuir a população institucionalizada. Dessa maneira, as agências passaram a colocar crianças negras em famílias brancas, sempre que não houvesse pais negros disponíveis. O número de adoções transraciais aumentou gradualmente para 733, em 1968, e mais do que triplicou nos três anos seguintes, atingindo o pico de 2.574, em 1971").

${ }^{202}$ Nesse sentido, MORRISON, Andrew. Transracial Adoption: The Pros and Cons and The Parent's Perspective. Harvard BlackLetter Law Journal, vol. 20, pp.166-67, 2004. 
declaração impulsionou a publicação de diversos trabalhos sobre a matéria e permitiu a criação de uma política contrária à mistura de raças pelas agências de adoção, públicas e privadas do país.

Passados quase cinquenta anos da primeira declaração contrária à medida, as controvérsias sobre a viabilidade da adoção inter-racial nos Estados Unidos continuam as mesmas.

Em trabalho publicado em 2004, Andrew Morrison ${ }^{203}$ menciona que os oponentes da adoção inter-racial afirmam, com fundamento nos argumentos apresentados pelos membros da The National Association of Black Social Workers, que esta medida é prejudicial aos interesses do adotando, da comunidade negra e do adotante, não devendo ser incentivada pelas agências de adoção ou pela sociedade.

No que se refere aos prejuízos causados ao adotando, sustentam os oponentes que somente pais negros têm condições de (1) ensinar às crianças negras como lidar com o preconceito racial; (2) avaliar, diante de insultos raciais, se a criança deve reagir ou recuar; (3) enfatizar a "força negra" sempre que a criança se deparar com insultos raciais e (4) avaliar, objetiva e subjetivamente, as diferenças de oportunidades entre grupos raciais, no que se refere à educação, ao trabalho e aos negócios.

Como se não bastasse, as pessoas contrárias à adoção inter-racial alegam que as crianças negras acolhidas por famílias brancas enfrentarão, mais cedo e necessariamente, o estigma da adoção, uma vez que não conseguirão esconder o fato de não serem filhos biológicos dos adotantes. Neste aspecto, os defensores da adoção entre pessoas da mesma raça afirmam que a adoção sempre traz a ideia de que a criança foi abandonada, não desejada ou sofreu abusos físicos e psicológicos, razão pela qual o seu conhecimento por terceiros prejudica a aceitação social do adotando.

${ }^{203}$ MORRISON, Andrew. Transracial Adoption: The Pros and Cons and The Parent's Perspective. Harvard BlackLetter Law Journal, vol. 20, pp.177-187, 2004. 
Com fundamento nos argumentos acima, os oponentes concluem que a adoção inter-racial prejudica o desenvolvimento da criança, impedindo que ela construa uma identidade racial adequada. ${ }^{204}$

No que se refere aos prejuízos causados à "comunidade negra", sustentam estes estudiosos que a aceitação da adoção inter-racial representa um genocídio da cultura negra, uma vez que apenas os pais negros conseguem transmitir a identidade cultural negra aos seus filhos e que o incentivo desta medida permite a formação da impressão de que os negros são incapazes de criar os seus próprios filhos.

Por fim, no que diz respeito aos danos causados aos adotantes, alegam os oponentes que estas pessoas (1) certamente sofrerão hostilidade e preconceito, da sociedade e da própria família, por terem adotado crianças negras, (2) terão que responder perguntas sobre a adoção muito mais cedo do que aqueles pretendentes que escolheram adotar crianças da mesma raça que a sua, (3) sofrerão o estigma da infertilidade, uma vez que serão incapazes de ocultar o fato de terem adotado uma criança e (4) serão incapazes de cuidar, de forma adequada, do cabelo e da pele da criança, submetendo-a a situações vexatórias.

Corroborando parte dos argumentos acima mencionados, porém sob outra perspectiva, a pesquisadora Gina Miranda Samuels, ${ }^{205}$ da Universidade de Chicago, esclarece porque os casais brancos preferem adotar crianças ao menos parcialmente brancas. Dentre os motivos, são citados os seguintes: (1) eles terão mais em comum com crianças com características multirraciais; (2) eles sentem um vínculo mais legítimo com crianças com quem compartilham uma herança genética semelhante; (3) eles se sentem menos culpados em "tirar" uma criança da comunidade negra e (4) uma criança mestiça será menos diferente visualmente e mais "fácil de explicar" aos parentes.

Entretanto, após avaliar os pontos contrários da adoção inter-racial, Andrew Morrison defende, com base em estatísticas e trabalhos científicos, que as vantagens da medida superam, em muito, as suas desvantagens, não causando a medida prejuízos ao desenvolvimento das crianças e adolescentes nela envolvidos, aos adotantes e à sociedade.

\footnotetext{
${ }^{204}$ Nesse sentido, vide também SILVERMAN, Arnold R. Outcomes of Transracial Adoption. The Future of Children. Adoption, n. 1, vol. 3, pp.110-11 Spring 1993.

${ }^{205}$ SAMUELS, Gina Miranda. Being Raised by White People: Navigating Racial Difference Among Adopt Multiracial Adults. In Journal of Marriage and Family 71, p. 81, February 2009.
} 
Quanto aos adotandos, as pesquisas ${ }^{206}$ realizadas nos Estados Unidos demonstram que as crianças negras adotadas por pessoas brancas não apresentam problemas de identidade ou de baixa-estima. Muito pelo contrário, constatou-se que: (1) a adoção interracial permite que a criança perceba que os seus pais não pretendem imitar a família biológica, estimulando este fato o desenvolvimento de sua identidade racial; (2) a adoção inter-racial é fundada no afeto e não nos laços de sangue, deixando claro que a criança é deseja pelos pais. Este fato possibilita um relacionamento saudável entre adotante e adotado; (3) os pais que adotam crianças de raça diversa da sua estão mais aptos à adoção, já que entendem que brancos e negros merecem ser tratados de forma igualitária e aceitam as diferenças raciais. ${ }^{207}$

Ademais, os adeptos da adoção inter-racial sustentam que a medida apresenta vantagens também à sociedade, uma vez que ajuda a aliviar o racismo e a tensão racial. Neste contexto, o contato social ${ }^{\mathbf{2 0 8}}$ contínuo entre pessoas de raças diversas permite a redução do racismo, por meio da aceitação das diferenças e da compreensão de que todas as pessoas, independentemente de sua raça, devem ser tratadas de forma digna.

Finalmente, no que diz respeito aos adotantes, Andrew Morrison sustenta que a adoção inter-racial (1) permite que os adotantes conheçam uma nova cultura, beneficiando tanto a si próprios como aos filhos; (2) demonstra aos adotantes a importância de ações

\footnotetext{
${ }^{206}$ Como bem lembrado por Elizabeth Bartholet, as pesquisas e estudos realizados nos Estados Unidos tinham como finalidade averiguar o sucesso das adoções transraciais, do ponto de vista dos adotandos e das famílias adotivas, levando em consideração os seguintes fatores: adaptação, auto-estima, identidade racial e integração do adotando à família adotiva e à comunidade. Os estudos mais recentes tendem a se basear nas críticas feitas à adoção transracial ou, mais especificamente, nos pontos negativos da medida. Pouquíssimos estudos têm como base os pontos positivos da adoção transracial e quase nenhum é voltado à análise dos aspectos potencialmente negativos da política racial das agências de adoção (BARTHOLET, Elizabeth. Where do Black children belong? The politics of race matching in adoption. University of Pennsylvania Law Review, n. 05, vol. 139, p. 1207-1208, may 1991).

${ }^{207}$ Neste sentido, conferir: MORRISON, Andrew. Transracial Adoption: The Pros and Cons and The Parent's Perspective. Harvard BlackLetter Law Journal, vol. 20, pp.187-89, 2004.

${ }^{208}$ De acordo com as palavras de MORRISON, Andrew. Transracial Adoption: The Pros and Cons and The Parent's Perspective. Harvard BlackLetter Law Journal, vol. 20, p.190, 2004. “(...) The 'social contact' theory is based on the idea that prejudice can be reduced by simply showing, through contact, that people with different appearances can have beliefs, interests, values, and fears that are similar to those of people who have similar appearances. Social contact theorists suggest that only certain types of social contact reduce prejudice. In particular, the quality of the social contact is vital to successful change (...)" (" A teoria do contato social é baseada na ideia de que o preconceito pode ser reduzido pela simples demonstração, através do contato, de que pessoas com aparência diversa podem ter crenças, interesses, valores e medos similares àqueles de pessoas com aparência semelhante. Os teóricos do contato social sugerem que apenas alguns tipos de contato social reduzem o preconceito. Particularmente, a qualidade do contato social é vital para o sucesso da mudança").
} 
afirmativas contra o racismo e (3) aumenta a aceitação dos adotantes brancos pelas comunidades negras. ${ }^{209}$

Frise-se que o fato de a adoção inter-racial não permitir que a filiação afetiva seja ocultada, expondo tanto a criança quanto os adotantes aos estigmas sociais, não torna a sua concessão, por si só, desvantajosa. Isto porque, conforme já mencionado no decorrer deste trabalho, a adoção deve ser o mais transparente possível, a fim de evitar tensões e ansiedades não apenas entre os interessados, como também entre estes e terceiros (sejam estes terceiros familiares ou não).

A diferença racial, por impedir que os pais e os filhos escondam de si próprios, da família e da sociedade a filiação adotiva, permite que os interessados tratem de forma natural esta ligação afetiva, sem medos e preconceitos, abrindo as portas para que a sociedade aceite aquilo que eles já aceitaram: o amor e o respeito entre pessoas de raças diversas são possíveis.

Nesse sentido, vale transcrever a lição da doutrina:

\begin{abstract}
Uma pérola trazida pela filiação adotiva é o encontro de etnias em uma só família. Há quem se preocupe com a adoção inter-racial, como foi denominada, porque temem que a criança sofra constrangimentos com as perguntas e inquietações que uma família colorida pode suscitar. Põem na sociedade a culpa do preconceito racial e assumem postura condizente com este mesmo preconceito, deixando de experimentar esta mistura por temerem o julgamento alheio. É claro que há racismo. Mas eu não preciso me comportar como este racismo determina: sendo branco, que eu tenha filhos brancos. Posso escolher uma luta amorosa contra esta imposição ridícula e impor uma nova lógica na qual me liberto e me permito amar sem preconceito. Amor colorido, que pode ser branco, negro, com olhos puxados, amarelinho, cabelo escorrido de índio, enfim, posso ser integralmente humano, por ser esta a única identidade pura: a raça humana. Famílias coloridas são uma nova tônica, sendo a adoção inter-racial cada vez mais comum. ${ }^{210}$
\end{abstract}

Dessa maneira, restou cientificamente comprovado que a adoção inter-racial não causa prejuízo aos interesses das crianças, dos pais adotivos e da sociedade, devendo ser afastados os argumentos contrários levantados pela NABSW e pelos demais críticos da medida.

\footnotetext{
209 Neste sentido: MORRISON, Andrew. Transracial Adoption: The Pros and Cons and The Parent's Perspective. Harvard BlackLetter Law Journal, vol. 20, p.192, 2004.

${ }^{210}$ SILVA, Sávio Renato Bittencourt Soares. Guia do Pai Adotivo. Orientações para uma Adoção Feliz. $2^{\mathrm{a}}$ ed. Curitiba: Juruá, 2012. p. 77.
} 
No mais, a tese de que a política de combinação racial se caracteriza como ação afirmativa é absolutamente infundada, uma vez que toda ação afirmativa pressupõe um olhar mais para o passado do que o futuro, duração limitada no tempo e a eliminação do critério racial como base para a tomada de decisões. A política de combinação racial, pelo contrário, olha para o futuro tanto quanto olha para o passado, não tem nenhum limite temporal e incentiva a consideração racial na tomada de decisões, provocando o separatismo racial ao invés da integração racial. ${ }^{211}$

Com base neste raciocínio, é possível afirmar que a política de estímulo à adoção inter-racial se enquadra bem mais no objeto da ação afirmativa ${ }^{212}$ que a sua política contrária, aqui combatida. Tanto isso é verdade que o incentivo à adoção inter-racial tem como finalidade promover a integração racial, até que solucionado o problema da institucionalização das crianças brasileiras. Uma vez alcançada a situação almejada pela lei- manutenção das crianças em suas famílias biológicas-, não haverá mais motivos para o Poder Público e a sociedade insistirem na adoção como medida de inserção familiar e social.

Ressalte-se, porém, que apesar de insubsistentes, os argumentos contrários à adoção inter-racial possuem a valia de demonstrar as dificuldades que podem ser enfrentadas pelos adotantes e pelos adotandos durante e após o processo de adoção, permitindo que os envolvidos, a sociedade e o Poder Público se preparem para a sua concretização.

Não há como se negar que a diversidade racial pode provocar questionamentos e discriminação ${ }^{213}$ contra os adotandos e os adotantes.

\footnotetext{
211 Nesse sentido, vide BARTHOLET, Elizabeth. Where do Black children belong? The politics of race matching in adoption. University of Pennsylvania Law Review, n. 05, vol. 139, p. 1232-33, may 1991.

${ }^{212}$ As ações afirmativas foram previstas no artigo $1^{\circ}$, da Convenção Internacional para a Eliminação de Todas as Formas de Discriminação Racial (1968), nos seguintes termos: “(...) 4. Não serão consideradas discriminação racial as medidas especiais tomadas com o único objetivo de assegurar o progresso adequado de certos grupos raciais ou étnicos ou de indivíduos que necessitem da proteção que possa ser necessária para proporcionar a tais grupos ou indivíduos igual gozo ou exercício de direitos humanos e liberdades fundamentais, contanto que tais medidas não conduzam, em consequiência, à manutenção de direitos separados para diferentes grupos raciais e não prossigam após terem sido alcançados os seus objetivos".

${ }^{213}$ De acordo com o artigo $1^{\circ}$, da Convenção Internacional para a Eliminação de Todas as Formas de Discriminação Racial (1968), discriminação racial significa “(...) toda distinção, exclusão, restrição ou preferência baseada em raça, cor, descendência ou origem nacional ou étnica que tenha por objeto ou resultado anular ou restringir o reconhecimento, gozo ou exercício em um mesmo plano (em igualdade de condição) de direitos humanos e liberdades fundamentais nos campos político, econômico, social, cultural ou em qualquer outro campo da vida pública (...)”.
} 
Por estes motivos, que são reais (apesar de insuficientes para tornar esta modalidade de adoção inviável), a adoção inter-racial demanda um acompanhamento psicossocial antes, durante e após o seu processo, com a finalidade de preparar os pais e os filhos para os desafios que serão enfrentados em razão da diversidade racial (vide tópico seguinte).

Vale lembrar, ademais, que alguns dos argumentos expostos acima, contrários à adoção inter-racial, são mais justificáveis na sociedade norte-americana, que enfrentou conflitos raciais violentos nas décadas de 50-60, do que na sociedade brasileira, tida como exemplo de miscigenação e de democracia racial, ${ }^{214}$ ainda que nela não se negue a existência de preconceito e de discriminação. ${ }^{215}$

214 "Somente com Gilberto Freyre o Brasil se reconheceu mulato. Mulato, cabloco, pardo, cafuso, curiboca, mestiço mazombo, enfim, sua população sempre fora, desde que os primeiros portugueses vieram instalar-se, sem mulheres, nas terras coloniais transatlânticas, desde que os primeiros escravos africanos foram trazidos à força para trabalhar na lavoura do açúcar. Não obstante a tentativa de caiação realizada até então pela política imigratória, a partir da década de 30, o Brasil oficial, precedido nos anos 20 pelo Brasil artístico do Movimento Modernista, passou aos poucos a declarar assumir-se filho natural e cultural das três raças formadoras- ou, conforme explicitava Freyre, resultado antropológico de acasalamentos híbridos, por vezes até sacramentados pela religião oficial, do varão português com a índia fêmea, dos senhores e sinhozinhos da casa-grande com as negras domésticas e da senzala. Isso sem falar da massa maior e mais popular de nossa gente, oriunda da mestiçagem entre afro-brasileiros forros e foragidos com brancos pobres e a população nativa, nesses casos sem nenhum nexo sociológico entre o sexo e a parceria de esteira, rede e capim. (...) Negativo para o movimento negro, positivo para o uso externo, o fato é que o mito da democracia racial "pegou", no Brasil e no exterior. Conhecido como país do samba, das mulatas e do futebol (futebol do negro Pelé e do mulato Garrincha, mais que do alourado Zico ou do "italiano" Toninho Cerezo), o Brasil ainda é apontado alhures, com freqüência, como terra de miscigenação, tolerância e igualdade racial. Até por Nelson Mandela. Sabe-se, no presente, e em geral se admite, que nossa democracia racial era meramente formal. Compreende-se, no Brasil atual, que esse mito prejudicou uma conscientização mais tempestiva dos fatores discriminatórios que mantêm em posição de inferioridade os cidadãos "de cor". A crença numa ausência de preconceitos malévolos, intrínseca a nosso povo, ainda que decorrente das condições de escravidão de que fez uso a "lascívia" lusitana, ademais de encobrir o racismo existente, facilita a perpetuidade das condições sociais de pobreza e de marginalização da maioria dos nossos negros. Ao mesmo tempo em que faz arrefecer as cobranças de parte dos discriminados, desvanece eventuais sentimentos de culpa nas camadas dominantes. Por outro lado, é também inegável que em poucos lugares, se é que algum há em qualquer dos continentes, tanta gente aparentemente branca voluntária e prazerosamente se declara preta, mulata, cabocla ou "com um pé na África”. A ilusão de uma democracia racial faz, sem dúvida, confundir uma realidade complexa, na qual o preconceito se pratica, mas não se assume (...)" (LINDGREN ALVES, José Augusto. No Peito e na Raça: a Americanização do Brasil e a brasilianização da América. Revista Impulso, n. 27, pp. 135-136, set./2000). (grifos do autor)

${ }^{215}$ De acordo com a lição de Daniela Ikawa, "Nessa direção, embora não haja no Brasil uma democracia racial, a discriminação é frequentemente mascarada por um apego apenas superficial ao princípio da igualdade ou, em outras palavras, um apego a uma igualdade meramente formal, alheia a resultados. Esse apego é consolidado pela estima persistente à excepcionalidade e à excelência da nossa alegada convivência interracial isenta de preconceitos e marcada pela miscigenação. Ainda, ao se tomar como padrão o caso americano de racismo, um racismo institucionalizado legalmente, acabou-se novamente por se esconder ou se mascarar a existência do racismo assimilacionista brasileiro. De fato, não existia no Brasil um racismo conflitivo e legal, e sim um racismo pautado em "uma refinada etiqueta de distanciamento social e uma diferenciação aguda de status e de possibilidades econômicas". Havia e há um racismo construído e justificado, ainda que implicitamente, por hierarquias morais convencionais não condizentes com o princípio constitucional (e universal) da dignidade (IKAWA, Daniela. Direito às Ações Afirmativas em Universidades 
Como bem colocado por José Augusto Lindgren Alves, apesar das semelhanças encontradas nas questões referentes ao preconceito racial no Brasil e nos Estados Unidos, a luta pela conquista dos direitos civis dos afro-americanos foi marcada por um elemento inexistente (ou, ao menos, existente em menor escala) em nosso país: a cultura do ódio racial. $^{216}$

Esta diferença é também lembrada pelo Relatório de Desenvolvimento Humano do Brasil (2005), que afirma que o racismo no Brasil possui um perfil diferente do racismo nos Estados Unidos, principalmente em razão da miscigenação racial ocorrida no Brasil e de suas consequências sociais e jurídicas. Nesse sentido:

\begin{abstract}
Se, como foi dito anteriormente, o racismo é uma estrutura de dominação baseada no pressuposto ideológico da existência de uma hierarquia entre as "raças" humanas, o sistema racial brasileiro apresenta singularidades. Nos Estados Unidos, por exemplo, o racismo fundou-se na ascendência - ou seja, é a herança genética que define a identificação racial-, o que levou a uma classificação bipolarizada das "raças" negra e branca. Enquanto isso, no Brasil, o racismo prende-se às características fenotípicas, como cor da pele e textura do cabelo. É uma espécie do racismo de marca, e não de origem. Em função disso, o racismo brasileiro manifesta-se em gradação, atingindo mais as pessoas com um fenótipo mais próximo da ancestralidade africana e matizando as discriminações conforme a aparência se aproxime do fenótipo branco.

Esse sistema de classificação se explica por uma série de fatores históricos, demográficos, sociais e políticos, que construíram o padrão de relações raciais no Brasil. O principal deles é a miscigenação, que foi influenciada pelas condições demográficas do empreendimento colonial: prevalência de homens brancos escravistas procriando com poucas mulheres da mesma cor, mulheres indígenas e escravas negras. A miscigenação favoreceu uma percepção gradual da cor da pele e, ao mesmo tempo, tornou multirracial a sociedade brasileira, o que explica, segundo alguns estudiosos, a inexistência de uma cultura de ódio racial explícito no Brasil.

Outra característica associada à miscigenação que singulariza o racismo no Brasil foi a inexistência de leis e instituições segregacionistas - não se erigiu no país uma legislação determinando a separação de negros e brancos nos ônibus, escolas, igrejas e bairros. A segregação formal foi impossível por força de condições demográficas, pois a maioria da população brasileira era composta por negros e seus descendentes, e por razões políticas, visto que membros ilustres das elites eram mestiços e não fizeram uso de mecanismos de auto-exclusão. Isso não significa, contudo, que não havia - e não haja - uma sociedade racialmente dividida: informalmente, com o uso de mecanismos sociais - sobretudo o pertencimento de classe -, os negros foram segregados nas áreas mais degradadas dos centros urbanos e rurais e nas regiões economicamente menos dinâmicas do país. (grifos no original)
\end{abstract}

Brasileiras. In SARMENTO, Daniel; IKAWA, Daniela; PIOVESAN, Flávia. Igualdade, Diferença e Direitos Humanos. Rio de Janeiro: Lumen Juris, 2010. p. 391).

${ }^{216}$ Sobre o assunto, conferir: LINDGREN ALVES, José Augusto. No Peito e na Raça: a Americanização do Brasil e a brasilianização da América. Revista Impulso, n. 27, p. 140, set./2000). 
Nos Estados Unidos, o assassinato de Martin Luther King e a cultura do ódio racial originaram a formação de grupos que lutavam não só pelo reconhecimento dos direitos civis e políticos dos afro-americanos, como também pelo reconhecimento da superioridade da raça negra. Estes grupos não se contentavam com o reconhecimento da igualdade formal e material entre brancos e negros, mas buscavam o fortalecimento da "comunidade negra" e de sua identidade, de forma absolutamente independente da "comunidade branca".

As ideologias políticas que marcaram as lutas raciais nos Estados Unidos trouxeram consequências diretas para a formação da família norte-americana, especificamente para a filiação adotiva. Tanto isso é verdade que, apesar de não haver legislação nesse sentido (até porque estas leis seriam inconstitucionais, por adotarem a raça como critério de discriminação na tomada de decisões), as agências de adoção norte-americanas, públicas e privadas, após o pronunciamento The National Association of Black Social Workers (NABSW), em 1972, acolheram a política de rejeição das adoções inter-raciais (também conhecida como política da combinação racial).

Com a finalidade de solucionar o problema da ausência de compatibilidade entre o número de adotandos negros disponíveis para adoção e de adotantes negros interessados na medida, os críticos da adoção inter-racial defendem a promoção das seguintes políticas, a saber: (1) recrutamento de famílias negras para adoção, com a ajuda da igreja, da comunidade negra e da mídia; (2) concessão de subsídios pelo Governo Estadual e pelo Governo Federal às pessoas negras que adotam crianças negras, até estas atingirem a maioridade; (3) relativização dos critérios tradicionais, utilizados para análise da capacidade dos adotantes negros de atender às necessidades das crianças envolvidas na adoção e (4) tentativas de manutenção da criança em sua família de origem. ${ }^{217}$

Frise-se que, como regra, os assistentes sociais nos Estados Unidos dão preferência à adoção de crianças por pessoas casadas, abaixo de sessenta anos, com estabilidade financeira e valores próprios da classe média americana. No caso de crianças negras, com a finalidade de permitir a adoção entre pessoas da mesma raça, os assistentes sociais admitem candidatos mais velhos, solteiros e dependentes de auxílio econômico do

\footnotetext{
${ }^{217}$ Nesse sentido, conferir BARTHOLET, Elizabeth. Where do Black children belong? The politics of race
} matching in adoption. University of Pennsylvania Law Review, n. 05, vol. 139, p. 1196-1200, may 1991. 
Governo. Este tratamento diferenciado entre os interessados na adoção faz com que o perfil dos adotantes brancos seja bem diferente do perfil dos adotantes negros.

Ainda que se admita que os critérios adotados pelos assistentes sociais norteamericanos para análise da capacidade dos adotantes sejam extremamente rígidos e não atendam à preservação dos interesses das crianças institucionalizadas, fato é que a sua relativização, sem qualquer parâmetro, apenas para possibilitar a adoção de crianças negras por pessoas da mesma raça que a sua, pode ser extremamente prejudicial aos interesses dos adotandos.

Isto porque, a abertura indiscriminada da adoção pode gerar o reconhecimento da paternidade em favor de pessoas absolutamente despreparadas para esta responsabilidade. E, como se sabe, de acordo com a legislação vigente, no Brasil e nos Estados Unidos, a raça não pode ser um fator de discriminação na colocação de crianças em famílias substitutas. $\mathrm{O}$ fator preponderante na análise desses casos deve ser, sempre, $\mathrm{o}$ interesse das crianças envolvidas.

No que diz respeito especificamente ao incentivo da permanência das crianças com sua família biológica, apesar de esta ser a situação visada pela sociedade e pelo Estado, a sua concretização depende não apenas da vontade dos pais em modificar a sua atitude perante os próprios filhos e a sociedade, como também de recursos financeiros do Governo. Isto porque, muitos desses pais são pobres e precisarão da assistência do Governo para conseguir reunir condições emocionais, espirituais e econômicas para zelar pelos interesses de seus filhos.

Neste contexto, ao tentar ampliar a lista dos adotantes negros, os assistentes sociais norte-americanos vêm conseguindo o tipo de pais em potencial que eles normalmente rejeitariam. Nas palavras de Elizabeth Bartholet: ${ }^{218}$

\footnotetext{
218 "Recruitment can be used to pressure people who have no genuine interest in parenting to adopt children for whom they are told no home is available. Subsidies can be used to encourage people who have real financial needs but no real interest in a child to agree to an adoptive placement. Many of those I spoke to voiced their fears that racial matching policies had in fact produced, on a widespread basis, placements with families that were not capable of or interested in providing appropriate parenting-families that they characterized as substandard or unfit" (BARTHOLET, Elizabeth. Where do Black children belong? The politics of race matching in adoption. University of Pennsylvania Law Review, n. 05, vol. 139, p. 1206-07, may 1991).
} 


\begin{abstract}
O recrutamento pode ser utilizado para pressionar pessoas que não possuem genuíno interesse na paternidade em adotar crianças que não possuem qualquer perspectiva de obter um lar. Os subsídios podem ser usados para encorajar pessoas que possuem necessidades financeiras, mas nenhum interesse em uma criança, a concordar com a adoção. Muitas pessoas com quem eu conversei demonstraram preocupação com o fato de que as políticas de "combinação racial" produziram, na realidade, a colocação de crianças em famílias que não estavam interessadas em proporcionar uma paternidade adequada- famílias que eles caracterizaram como abaixo do padrão ou inadequadas.
\end{abstract}

No Brasil, não existe uma política declarada contra a adoção inter-racial ou de promoção da colocação de crianças negras em famílias negras, como ocorre nos Estados Unidos. Muito pelo contrário, em razão da formação racial de nosso povo e do fato de existirem mais crianças negras disponíveis para adoção, os assistentes sociais e os magistrados que atuam junto às Varas da Infância e da Juventude vêm buscando incentivar as adoções inter-raciais, como forma de possibilitar a convivência familiar das diversas crianças institucionalizadas no país.

Apesar desses esforços- que são mais recentes-, as pesquisas demonstram que os adotantes ainda preferem adotar crianças da mesma raça que a sua, em clara demonstração de que o critério biológico é preponderante na formação das famílias brasileiras.

Dessa maneira, ainda que as estatísticas demonstrem que as adoções inter-raciais são bem inferiores às adoções entre pessoas da mesma raça, no Brasil e nos Estados Unidos, as causas desse fenômeno são diferentes nestes dois países. E uma comparação destas causas permite concluir que a solução do problema brasileiro parece mais fácil que a transposição das dificuldades enfrentadas nos Estados Unidos.

Tanto isso é verdade que, nos Estados Unidos, a adoção inter-racial encontra resistência dos adotantes e do próprio sistema, ao passo que no Brasil a resistência à medida tem como causa somente a preferência dos interessados (ainda que esta preferência tenha como causa fatores sociais). Uma vez ultrapassada a barreira da aceitação da adoção inter-racial, por ele mesmo imposta, o interessado não encontrará resistência no próprio sistema. $\mathrm{O}$ mesmo não se pode dizer da realidade norte-americana.

Resta saber, dessa maneira, como solucionar o problema da resistência pessoal à adoção inter-racial. 
Esta questão também foi abordada nos Estados Unidos, ainda que de forma bem mais superficial que aquela relativa às políticas de combinação racial adotada pelas agências de adoção.

O professor da Universidade de Stanford, Richard Banks, observa que a resistência à adoção inter-racial nos Estados Unidos tem como causa não apenas a política de combinação racial, como também a preferência dos próprios interessados.

Na oportunidade, alerta o autor que a eliminação da política de combinação racial, nos termos defendidos por Elizabeth Bartholet, no artigo Where do Black Children Belong? The politics of race matching in adoption, aqui estudado, não soluciona o problema da institucionalização prolongada das crianças negras nos Estados Unidos.

Isto porque, a classificação das crianças por raça e a possibilidade de os adotantes escolherem as crianças que desejam adotar de acordo com a sua preferência racial possibilita a discriminação e promove a desigualdade racial. Nesse sentido:

\begin{abstract}
A classificação das crianças, realizada pelas agências de adoção, com base na raça facilita e promove o exercício de preferências raciais por pretensos adotantes. Eu nomeio desta prática de facilitação de acomodação (facilitative accommodation). Quando praticada por agências públicas, esta prática, assim como a colocação de menores em famílias que tenham a mesma raça que a sua, representa uma forma de ação fundada na raça. Através da combinação racial, o Estado determina a colocação de crianças em famílias substitutas com base na raça dos envolvidos. Através da política de "facilitação de acomodação", a classificação estatal com base na raça influencia na tomada de decisões dos adotantes, em razão do enquadramento das crianças disponíveis de acordo com a raça, encorajando os pais a escolher nas crianças com base na raça e não em suas características individuais. Em ambos os casos, o Poder Judiciário, ao conceder a adoção, valida as políticas adotadas pelas agências.

Como resultado desta política, nega-se a oportunidade, à maior parte das crianças negras disponíveis para adoção, de serem vistas de forma individualizada pelos pretendentes. Isto poderia não acontecer se esta prática não existisse. A classificação racial utilizada pela política de facilitação de acomodação ocasiona o tipo de prejuízo proibido pela Cláusula de Proteção Igualdade.

Pior ainda, a política de facilitação de acomodação reforça e legitima o tipo de consciência racial que produz a desigualdade racial injustificável, tanto nos processos de adoção como na sociedade em geral. A preferência racial dos pretensos pais adotivos diminui consideravelmente o campo de pais potenciais disponíveis para as crianças negras, quando em comparação com as crianças brancas. ${ }^{219}$ (grifos do autor)
\end{abstract}

219 “Adoption agencies' classification of children on the basis of race facilities and promotes the exercise of racial preferences by prospective adoptive parents. I term this practice 'facilitative accommodation'. When engaged in by public agencies, facilitative accommodations, like race matching, is an instance of race-based state action. In both cases, adoption agencies racially classify children. Through race matching, the state mandates the placement of children with parents on the basis of race. Through facilitative accommodation, 
Richard Banks sugere a eliminação da possibilidade do exercício de preferência racial pelos adotantes, como forma de evitar a discriminação e a exclusão das crianças negras da convivência familiar. Segundo o professor, "as preferências raciais dos indivíduos não são naturais, mas sim o produto das regras e políticas sociais relativas à identidade racial e à consciência racial no país".220

A tese defendida pelo autor é uma crítica parcial ao pensamento de Elizabeth Bartholet, na obra citada acima, especialmente no que se refere à liberdade dos adotantes manifestarem a sua preferência racial no momento da candidatura/habilitação à adoção. Nas palavras do autor: ${ }^{221}$

\begin{abstract}
Bartholet não trata a facilitação de acomodação como uma política social baseada na raça. Apesar de suas observações indicarem que os adotantes brancos preferem crianças brancas e que ela acredita que as polícias baseadas em raça promovem as preferências baseadas em raça, Bartholet não identifica nenhuma política baseada em raça, além da combinação racial, a que estas preferências estejam ligadas. Ela analisa a combinação racial, mas não apresenta quase nenhuma crítica com relação à facilitação de acomodação.
\end{abstract}

the state's racial classification promotes the race-based decision making of prospective adoptive parents by framing the choice of a child in terms of race, encouraging parents to consider children based on the ascribed characteristic of race rather than individually. In both cases, a court, in finalizing the adoption, validates the actions of the adoption agency. As a result of facilitative accommodation policies, most black children in need of adoption are categorically denied, on the basis of race, the opportunity to be considered individually for adoption by the majority of prospective adoptive parents. This could not occur were it not for current policies of facilitative accommodation. The racial classification on witch facilitative accommodation practices rely is the type of harm prohibited by the Equal Protection Clause. Worse, facilitative accommodation reinforces and legitimizes the type of race-consciousness that produces unjustified racial inequality, both in adoption and throughout the American society. Adoptive parents' racial preferences dramatically diminish the pool of potential parents available to black children relative to that available to white children" (BANKS, Ralph Richard. The Color of Desire: Fulfilling Adoptive Parent's Racial Preferences Through Discriminatory State Action. 107 Yale Law Journal, pp. 880-881, 1998)..

220 “(...) racial preferences are not natural, but rather are products of the ways in which legal rules and social policy have shaped racial identity and race-consciousness". (BANKS, Ralph Richard. The Color of Desire: Fulfilling Adoptive Parent's Racial Preferences Through Discriminatory State Action. 107 Yale Law Journal, pp. 883, 1998).

221 "Bartholet does not treat facilitative accommodation as a race-based social policy. Although her own observations indicate the prevalence of white parents' preference for white children, and she believes that race-based policy promotes race-based preferences, Bartholet identifies no race-based social policy, other than race matching, to which such preferences are linked. She comprehensively analyzes race matching but offers almost no critique of facilitative accommodation. (...) Bartholet's condemnation of race matching and endorsement of parental autonomy represent a reasonable response to the dilemma of race and adoption. The cessation of race matching may later the disparate adoption rates of black and white children. Yet Bartholet's solution wrongly suggests that adoptive parents' racial preferences rise no issue of racial equality. The fact that race matching harms children does not mean that facilitative accommodation and adoptive parents' racial preferences do not. Racial preferences produce inequality just as surely as race matching, even if they produce it differently. Adoptive parents' racial preferences deny to black children access to a pool of potential adoptive parents comparable to that available to White children" (BANKS, Ralph Richard. The Color of Desire: Fulfilling Adoptive Parent's Racial Preferences Through Discriminatory State Action. 107 Yale Law Journal, pp. 893-94, 1998). 
(...)

A condenação da combinação racial e a defesa da autonomia dos pais, feitas por Bartholet, representam uma resposta razoável ao dilema da raça e da adoção. A extinção da política de combinação racial pode alterar as estatísticas desproporcionais de adoção de crianças negras e brancas. Entretanto, a solução dada por Bartholet, de forma equivocada, assume que a política de preferência racial não traz qualquer consequência para a desigualdade racial. $O$ fato de a política de combinação racial causar prejuízos às crianças não significa que a facilitação de acomodação e a preferência racial dos adotantes não faça o mesmo. As preferências raciais causam desigualdade da mesma forma que a combinação racial, mesmo que o façam de forma diversa. As preferências raciais dos adotantes brancos negam às crianças negras acesso a um grupo de pais adotivos em potencial em comparação com o grupo disponível para as crianças brancas.

\section{Em resposta à crítica feita por Richard Banks, Elizabeth Bartholet, ${ }^{222}$ em artigo}

publicado em 1998, esclarece que:

(...) Por que tantas pessoas acreditam que é natural, e apropriado, pensar em termos raciais no contexto familiar? Eu concordo, nos termos defendidos por Banks, que é importante questionar esta crença. Concordo que existe uma íntima ligação entre as preferências raciais privadas e as preferências raciais públicas, geralmente condenadas como discriminação. Eu concordo que as preferências raciais privadas não são inerentes, condições humanas inalteráveis, mas sim produto de nossos condicionamentos sociais. E eu concordo com Banks no sentido de que seria bom adotar medidas para mudar o modo como as pessoas pensam sobre raça no contexto familiar. Isto é uma dos motivos de eu ter advogado tanto tempo em favor da eliminação das barreiras estatais contra a adoção transracial, e porque eu argumentei que o Estado não poderia exercer qualquer preferência racial na colocação de crianças em famílias substitutas. Estas políticas não apenas evitam a formação de famílias transraciais, como também condicionam as pessoas a pensar de forma negativa sobre raça. (...)

222 “(...) Why are so many people so ready to assume that it is natural, and appropriate, to think in racial terms in the intimate family context? I agree with Banks that it is important to question this assumption. I agree that there is a connection between these private racial preferences and the public racial preferences that are generally condemned as 'discrimination'. I agree that private racial preferences are not inherent, unalterable condition of humankind, but rather products of our social conditioning. And I agree with Banks that it would be good to take steps to change the way people think about race in the family context. This is an important part of why I have long advocated elimination of state-imposed barriers to transracial adoption, and why I have argued that the state should not exercise any preferences whatsoever for placing children with racially matched families. Such policies not only prevent the formation of transracial families, but also condition people to think badly of racial intimacy. (...) Banks finds in an 'anomaly' that those of us opposing state-imposed barriers to transracial adoption have not addressed the issue of 'facilitative accommodation', as though we were not aware exists. Of course it exists, and of course it could be legally challenged. The issue for me, however, is whether it would be a good idea to try to eliminate private preferences with the coercive measures that Banks suggests. I agree that the state should take no action to encourage the exercise of private racial preference. But Banks go further, arguing that the state should not allow prospective adopters to consider race. Here I disagree with Banks. I do place some value on autonomy, and do not think the state should get in the business of limiting choice in marriage procreation, or adoptive relationships, unless absolutely necessary. And although I think it would be good for more people to cross racial and other lines of difference in the formation of their families, I do not think that ii is so clearly bad if many others form families on the basis of similarities in racial, religious, ethnic, and national heritage. Banks argues that his proposals will help alleviate the plight of many African-American children now held for long periods in foster care. I fear that if his proposal system were ever implemented it might hurt the life chances of the very children he wants to help" (BARTHOLET, Elizabeth. Private Race Preferences in Family Formation. The Yale Law Journal, n. 7, vol. 107, pp.2351-2353, May 1998). 
Banks acha que é uma "anomalia" que nós que nos opomos às barreiras estatais impostas contra a adoção transracial não abordemos o assunto das políticas de "facilitação de acomodação", como se não estivéssemos cientes de que o fenômeno existe. Claro que o fenômeno existe e claro que ele deveria ser alterado legalmente. Questiono, entretanto, se seria uma boa ideia eliminar as preferências privadas através das medidas coercitivas que Banks sugere. Eu concordo que o Estado não deveria adotar medidas para encorajar o exercício da preferência racial. Mas Banks vai além, argumentando que o Estado não deveria permitir que os pretensos pais considerassem a raça da criança.

Aqui eu discordo de Banks. Eu valorizo a autonomia, e não acredito que o Estado deveria limitar a escolha das pessoas com relação ao casamento, à procriação, ou os relacionamentos adotivos, a não quando estritamente necessário. E, apesar de pensar que seria bom que mais pessoas cruzassem a linha racial e outras linhas de diferença na formação de suas famílias, eu não penso que seja tão ruim se outras tantas pessoas formarem famílias com base em semelhanças raciais, religiosas, étnicas, e com herança nacional. Banks argumenta que sua proposta ajudará a solucionar o problema de muitas crianças negras, que permanecem anos em instituições. Eu receio que se o seu sistema fosse alguma vez implementado, ele poderia prejudicar as chances de vida das próprias crianças que ele pretende ajudar. (grifos da autora)

Dessa maneira, Elizabeth Bartholet, apesar de reconhecer que o exercício da preferência racial prejudica a formação de famílias transraciais, entende que a proibição pelo Estado do exercício desta preferência pode implicar em violação à autonomia individual e, em última análise, em prejuízo aos interesses das próprias crianças envolvidas. Isto porque, muitos pais adotariam crianças de raça diversa da sua por imposição legal e não por vontade própria, fator que poderia causar dificuldades na adaptação da família adotiva.

De fato, a preocupação de Richard Banks é real, mas a solução por ele apresentadaeliminação da possibilidade do exercício de preferência racial pelos interessados- parece não atender aos interesses dos envolvidos no processo de adoção, em especial das crianças que estão aguardando a possibilidade de serem inseridas em uma família substituta.

A preferência dos adotantes por crianças brancas, maior entrave da adoção interracial no Brasil, pode ser solucionada por meio de medidas menos dramáticas que aquelas propostas pelo professor da Universidade de Stanford. A preparação psicológica e a educação em direitos humanos são mecanismos voltados para a abertura da adoção interracial e para a conscientização dos valores da igualdade e da diferença, conforme será analisado nos próximos tópicos.

Feitas estas considerações a respeito da oposição, da defesa e dos desafios da adoção inter-racial, pode-se concluir que, ainda que compreensível a negação da medida 
por estudiosos norte-americanos, em virtude da valorização da identidade negra (individual e coletiva) e da dificuldade de se enfrentar o preconceito racial, ela não deve implicar no reconhecimento da divisão do mundo em duas comunidades distintas. Isto porque, os seres humanos, apesar de suas diferenças, integram uma única comunidade- a comunidade humana- sendo salutar que eles convivam de forma integrada e respeitosa.

Nesse sentido, vale a pena transcrever a lição de José Augusto Lindgren Alves, ${ }^{223}$ para quem é possível encontrar soluções para os problemas raciais brasileiros sem recorrer ao separatismo:

${ }^{223}$ LINDGREN ALVES, José Augusto. O Multiculturalismo Ideológico: Defeitos de uma Ideia BemIntencionada para Combater o Racismo. In PIOVESAN, Flávia e IKAWA, Daniela (coord). Direitos Humanos: Fundamento, Proteção e Implementação. Perspectivas e Desafios Contemporâneos. Curitiba: Juruá, 2009. v. II, pp.. 678-679.

Sejamos "multiculturalistas", sim, em qualquer dos sentidos integradores, de preferência com modelo nosso. É imprescindível que o Brasil, após tantos anos de lutas do movimento negro contra o branqueamento ostensivo ou disfarçado de nosso povo, continue a dar valor apropriado aos aportes fundamentais das culturas africanas e indígenas à originalidade da cultura brasileira. Nesta se inserem plenamente a capoeira, o candomblé, a macumba, as festas de Iemanjá, assim como as redes de dormir, as comidas típicas do Norte e da Bahia, a feijoada, o bumba-meu-boi e o samba, sem falar na figura histórica de Zumbi e no pioneirismo de Palmares nas lutas emancipatórias nacionais. $\mathrm{O}$ fato, atualmente recordado com intuito provocativo, de o Quilombo dos Palmares também haver funcionado com seus próprios escravos, não diminui seu valor histórico, nem seu simbolismo libertário para os escravos negros do homem branco, escravizados em função da "raça", numa fase em que o escravismo, de bases variadas, era legal e vigente em todo o mundo. Da mesma forma que seria absurdo desconsiderar os atos de resistência e rebeldia dos próprios escravos negros e mulatos, juntamente com as campanhas políticas de brancos e mestiços, no século XIX, para abolir nosso sistema de escravidão anacronicamente prolongado. Com nosso próprio reconhecimento do que somos, teremos mais razão até para exigirmos da comunidade internacional o reconhecimento da diferença brasileira.

Tendo sido negociador convicto de muitas das disposições da Conferência de Durban, sou favorável à adoção de ações afirmativas que ajudem a erradicar discriminações estruturais e preconceitos atávicos, elementos indescartáveis de nossos desequilíbrios. Não sei exatamente que ações são as mais adequadas para consolidar uma classe média negra com influência decisória em nosso país de mestiços, mas entendo que qualquer delas deverá ter destinação social definida.

É fato que as "diferenças" representam um aspecto novo na política brasileira. Acredito, porém, que para adotar ações afirmativas, o Brasil não necessita tornar-se "racialista" à americana, passando a enxergar tudo pelo viés das "relações raciais". Se tal distorção absurda num país misturado em tudo, menos na distribuição da riqueza, extrapolar as discussões teóricas para instalar-se em nosso cotidiano, o Brasil não estará indo ao encontro de soluções para problemas que atingem em graus particularmente elevados suas grandes "minorias". Estará acrescentando ao conjunto, em pulsão coletivamente suicida, um combustível a mais no fogo da caldeira já por demais aquecida, cujas apavorantes borbulhas de efeitos não-seletivos desafiam ostensivamente o Estado, delimitam-se à órbita 
criminal. Ou, se não se delimitam a ela, extravazam objetivos mais amplos, numa lógica acumulativa bem típica do capitalismo tacanho. (grifos do autor)

Frise-se, outrossim, que o argumento de que a adoção inter-racial trará prejuízos à formação da identidade da criança, em razão da impossibilidade de os adotantes brancos a inserirem na cultura da comunidade negra, deve ser afastado da prática nacional, quer porque o conceito de comunidade negra no Brasil é bem diverso daquele estabelecido pelos afro-americanos, quer porque o argumento não é verídico, conforme acima analisado.

As diferenças históricas entre o Brasil e os Estados Unidos, porém, não afastam a aplicação das obras estrangeiras aqui citadas à realidade brasileira, com as devidas adaptações, em especial em virtude da identidade dos problemas raciais enfrentados por ambos os países. Em outras palavras, a causa dos problemas raciais enfrentados pelo Brasil e pelos Estados Unidos é diversa (ainda que parcialmente coincidente), mas as suas consequências para as crianças negras são praticamente idênticas.

Tanto isso é verdade que os dados demonstram que nos Estados Unidos, assim como no Brasil, o número de crianças negras institucionalizadas é bem superior ao número de crianças brancas, ao passo que a grande maioria dos pretendentes à adoção é branca. ${ }^{224}$

Dessa maneira, com fundamento nas estatísticas e na realidade social de ambos os países, a rejeição da adoção inter-racial implicaria na institucionalização permanente ou por longo período de tempo de crianças negras, prejudicando seriamente o seu desenvolvimento físico, emocional e espiritual.

\footnotetext{
${ }^{224}$ Como bem lembrado por José Augusto Lindgren Alves, "Os negros dos Estados Unidos, autodenominados afro-americanos, além de terem atualmente participação ponderável na vida política e econômica nacional, compõem a população negra de melhor nível médio de vida do planeta. Educada e substancialmente abastada, em virtude do sistema da 'ação afirmativa', ora repudiado como anacrônico por alguns de seus beneficiários, a burguesia afro-americana não somente corresponde a parcela expressiva do mercado, como também influi significativamente na condução do país. Ocupa cargos importantes dos três ramos do Poder, nos três níveis da Federação, e funções de direção em empresas prósperas (quase sempre "étnicas')" (LINDGREN ALVES, José Augusto. No Peito e na Raça: a Americanização do Brasil e a brasilianização da América. Revista Impulso, n. 27, p. 140, set./2000). Este dado, porém, não desmente o fato de que ainda existem diversas crianças negras institucionalizadas no país, lembrando a sociedade da sua herança de preconceito, discriminação e desigualdade social. Afirma Elizabeth Bartholet que, a cada ano, mais de 25.000 jovens deixam os abrigos dos Estados Unidos, por completarem dezoito anos. Estes jovens, por terem crescido sem família e sem um lar estruturado, terão poucas perspectivas de vida. Muito provavelmente, estas pessoas serão vítimas de desemprego, crime, abuso e abandono (BARTHOLET, Elizabeth. Nobody's children. Abuse and Neglect, Foster Drift, and the Adoption Alternative. Boston: Beacon Press, 1999. p. 29).
} 
Como se viu neste tópico, a rejeição da adoção inter-racial é infundada, uma vez que, ao contrário do que sustentam os seus oponentes, ${ }^{225}$ ela permite um desenvolvimento do adotante, do adotando e da sociedade, sendo que suas desvantagens são ou comprovadamente falsas ou facilmente solucionadas.

É preciso reconhecer, nos termos defendidos por Elizabeth Bartholet (não apenas com fundamento em dados científicos, com também com base em sua experiência racial) que a injustiça racial e a injusta social são os pontos centrais da negligência e do abuso infantil, devendo o assunto ser tratado de forma direta e eficaz, com a finalidade de quebrar o ciclo vicioso estabelecido nas camadas mais pobres e negras da sociedade americana. Nesse sentido:

\footnotetext{
${ }^{225}$ Cumpre lembrar que também existiram vozes contrárias à adoção inter-racial no Brasil, conforme se percebe pela leitura dos ensinamentos de Valdir Sznick: "Uma criança loira, em um casal moreno, ou uma criança escura, em um casal de cor clara, será sempre fonte de problemas: não para os próprios adotantes, que considerarão, muitas vezes, essa adoção como uma benção, mas perante os demais, vizinhos, escola, pessoas de relação, pois alguma coisa se torna evidente, o que levará o casal a contar que se trata de filho adotivo, quebrando, por força da saciedade, aquele halo de mistério que não só o legislador quis resguardar, mas também colocando, aí, com essa revelação, sempre a criança (que é inocente quanto à sua cor) em uma situação, no mínimo, embaraçosa para ela. E tudo isso pode ser evitado, adotando-se uma criança- o que não é difícil- pelo menos, da cor da pele e caracteres assemelhados aos pais adotantes" (SZNICK, Valdir. Adoção. Direito de Família, Guarda de Menores, Tutela, Pátrio Poder, Adoção Internacional. $3^{a}$ ed. São Paulo: Liv. e Ed. Universitária de Direito, 1999. p. 402).
} 
pensarem nas crianças de toda a comunidade como sua responsabilidade, teremos mais chance de criar a sociedade justa, que é o nosso objetivo. ${ }^{226}$

Resta claro, assim, que não se trata de privilegiar a adoção inter-racial, em detrimento da adoção entre pessoas da mesma raça, até porque existem crianças brancas disponíveis para adoção (embora em menor quantidade).

Pretende-se neste trabalho, na mesma linha do que defende Elizabeth Bartholet, considerada referência em adoção inter-racial nos Estados Unidos, demonstrar que a adoção inter-racial é uma solução possível para o problema da institucionalização prolongada de crianças negras no Brasil, devendo ser estimulada pela sociedade e pelo Estado, sempre que os interesses da criança assim o exigirem.

Este estímulo, conforme se verá a seguir, será feito através do amparo psicológico a todos os envolvidos no processo de adoção e da educação, formal e informal, em direitos humanos.

\subsection{O amparo psicológico como mecanismo de esclarecimento e de estímulo às} adoções inter-raciais e tardias

A análise dos dispositivos do Estatuto da Criança e do Adolescente, alterado pela Lei n. 12.010/2009, deixa claro que o processo de adoção conta com a participação de

\footnotetext{
226 "The starting point for honest and meaningful debate has to be the recognition that racial and social injustice is at the core of child abuse and neglect. The parents who treat their children badly are themselves victims, and if we want to stop the vicious cycle, we need to create a society in which there is no miserable underclass, living in conditions which breed crime, violence, substance abuse, and child maltreatment. But at the same time we need to recognize that children who are growing up in foster and group homes, are also victims. Like their parents, they are often black and brown-skinned victims, and most of them are poor. Keeping them in their families and their kinship and racial groups when they won't get decent care in those situations may alleviate guilt, but it isn't actually going to anything to promote racial and social justice. It isn't going to help groups who are at the bottom of the socio-economic ladder to climb that ladder. It is simply going to victimize a new generation. Moving those children into nurturing homes will give them, at least, a chance to break the cycle. These homes might be with kin, they might be with same-race nonkin, they might be with other-race parents from the other side of town. What matters is that the children get into homes where they can thrive. But if we want to find truly nurturing homes for all the children in need, we have to reach out to the entire community. Most of the local villages at issue are not going to have enough good homes to spare. Encouraging people who are in position to provide good parenting to step forward, without regard to race or class or membership in the local village, encouraging to see children born to others as children they are responsible for, can be painted as a form of vicious exploitation. But that's not how I see it. It seems to me that if more members of the larger community thought of all the community's children as their responsibility, we'd have a much better chance of creating the just society that is our goal" (BARTHOLET, Elizabeth. Nobody's Children. Abuse and Neglect, Foster Drift, and the Adoption Alternative. Boston: Beacon Press, 1999. p. 6.
} 
equipe interprofissional, que tem como objetivo não apenas verificar se os candidatos estão aptos à adoção, como também (e principalmente) preparar os interessados para a filiação adotiva.

A principal crítica ao processo de adoção, em especial antes do advento da Lei n. 12.010/2009, era justamente a inexistência de preparo psicológico e emocional aos candidatos e às crianças envolvidas e a prolação de pareceres contrários à medida, sem qualquer tentativa de adequação das expectativas dos candidatos ou de justificativa. Nesse sentido, vale transcrever a lição de Lidia Natalia Dobrianskyj Weber: ${ }^{227}$

Muitos técnicos que trabalham nos Serviços de Adoção dos Juizados da Infância e da Juventude, em especial Assistentes Sociais e Psicólogos, adotam esta postura dogmática e estereotipada que sequer conseguem perceber seus próprios preconceitos. Trabalhar com adoção e chamar a família biológica de "normal" ou "natural" não parece preconceituoso? Ao se pensar nas antinomias, não se quer dizer que a família adotiva é "artificial" ou "anormal"? Técnicos dizem que é preciso "verificar se existem ou não contra-indicações (...) à luz de critérios previamente estabelecidos", e alguns textos de profissionais que trabalham com adoções costumam arrolar argumentos subjetivos e amplos, sem trazer especificidades para as "contra-indicações". Outros trazem claramente alguns exemplos contra a escolha de adotantes: por exemplo, um casal que adotaria uma criança de dois anos queria mudar seu nome e por este fato foi considerado inapto para a adoção. Foi correto? Em primeiro lugar, temos que ressaltar que o próprio Estatuto da Criança e do Adolescente permite esta mudança. Em segundo lugar, se esse casal não compreende a importância da construção da identidade de uma criança, não seria possível esclarecê-lo? Um simples fator é suficiente para rotular este casal de insensível e inapto para a paternidade? É preciso lembrar que estamos no Brasil, um país onde o acesso à informação, à educação, ao esclarecimento da maior parte da população é seletivo. A maioria das pessoas não toma leite com manga "porque faz mal", bate na madeira três vezes para "não dar azar", toma decisões com base no horóscopo do dia, acredita que os crimes de crianças e adolescentes aumentaram "por causa do Estatuto da Criança e do Adolescente”, não adotaria crianças que fossem filhos de prostitutas e assassinos porque "a marginalidade passa pelo sangue", acha que pelo fato de algumas mulheres engravidarem após a adoção, "adotar uma criança é um bom motivo para se tentar ter filhos naturais”, acredita que "quando uma criança não sabe que é adotada, surgem menos problemas", pensa que "somente os pais são culpados pelas crianças que estão nas ruas porque não souberam educá-las", ou que "é possível adotar crianças com mais de 10 anos de idade para que possam ajudar nos serviços domésticos". Não seria esperar demais que pessoas com essas idéias consigam entender as possíveis nuanças sobre a construção da identidade de uma pessoa e a relação com o seu nome? Acreditamos que seria possível esclarecer a acreditar na mudança, antes de excluir, senão as conhecidas avaliações pseudo-psicológicas podem tornar-se um modo perverso de discriminação e segregação. (grifos da autora)

${ }^{227}$ WEBER, Lidia Natalia Dobrianskyj. Aspectos Psicológicos da Adoção. $2^{\mathrm{a}}$ ed. Curitiba: Juruá, 2011. pp. 34-35. 
Esta postura- discriminatória e apriorística- acabou por levar o Poder Judiciário a negar diversos pedidos de adoção, antes mesmo de qualquer tentativa de preparo dos interessados para a filiação afetiva. Frise-se, aliás, que o preparo para a filiação é essencial não apenas para os interessados na adoção, como também para as pessoas que pretendem conceber uma criança (por todos os métodos possíveis). ${ }^{228}$

Atento a esta realidade e ao fato de existirem diversas crianças abrigadas, com perfil diverso daquele selecionado pelos candidatos, o Poder Legislativo exigiu a interferência de equipe interprofissional (formada por psicólogos e assistentes sociais) nas diversas fases do processo de adoção.

Sendo assim, a equipe formada por psicólogos e assistentes sociais deverá atuar nos seguintes momentos do processo de adoção, a saber: (1) habilitação dos candidatos (art. 50, $\S \S 1^{\circ}$ e $4^{\circ}$ do ECA); (2) oitiva das crianças e dos adolescentes sobre a conveniência e a adequação da medida, levando-se em consideração o seu grau de maturidade e de compreensão das consequências da adoção (art. 28, § $1^{\circ}$ do ECA); (3) fixação do período de estágio de convivência (art. 46, $\S 4^{\circ}$ e 167, do ECA do ECA) e (4) divulgação do processo de adoção ao interessado (art. 48, parágrafo único do ECA).

A atuação da equipe interprofissional nas hipóteses previstas nos itens 2,3 e 4 já foi objeto de estudo no presente trabalho, restando tão somente a análise da atuação dos psicólogos e assistentes sociais na fase de habilitação dos candidatos à adoção.

\footnotetext{
${ }^{228}$ Outra conseqüência importante da falta de preparo psicológico dos candidatos à adoção e da conseqüente negativa da medida, sem justificativa, é o estímulo das adoções à brasileira, consistentes no registro de filho alheio como próprio. Esta conduta, apesar de criminosa, acontece com frequiência no Brasil, em razão dos trâmites do processo judicial de adoção, tido por muitos como demorado e invasivo. Os nossos Tribunais, com fundamento na paternidade afetiva e no princípio do melhor interesse da criança, vêm afastando as sanções penais e civis da adoção à brasileira, dando prevalência à manutenção dos vínculos formados entre os adotantes e o adotado. Nesse sentido: "RECURSO ESPECIAL - AÇÃO DECLARATÓRIA DE NULIDADE DE REGISTRO CIVIL - NEGATIVA DE PRESTAÇÃO JURISDICIONAL - ALEGAÇÃO DE VIOLAÇÃO GENÉRICA - RECURSO ESPECIAL, NO PONTO, DEFICIENTEMENTE FUNDAMENTADO - APLICAÇÃO DA SÚMULA N. 284/STF - ADOÇÃO À BRASILEIRA PATERNIDADE SÓCIO-AFETIVA - IMPOSSIBILIDADE, NA ESPÉCIE DE DESFAZIMENTO RECURSO ESPECIAL IMPROVIDO. (...) A paternidade afetiva deve prevalecer sobre a biológica sempre que esta situação for mais benéfica aos interesses do menor. Caso, porém, a própria criança queira saber quem são seus pais biológicos, não pode ser impedida, uma vez que a adoção brasileira não rompe, por si só, os vínculos de filiação entre os pais naturais e seus filhos. (...) (REsp 1167993/RS, Rel. Ministro LUIS FELIPE SALOMÃO, QUARTA TURMA, julgado em 18/12/2012, DJe 15/03/2013).
} 
De acordo com a legislação, os requisitos objetivos e subjetivos da adoção, mencionados no item anterior, serão averiguados no momento da habilitação dos candidatos, que sempre será precedida da preparação psicossocial e jurídica, essencial para que os interessados sejam esclarecidos sobre as peculiaridades da filiação adotiva e a importância da paternidade afetiva, estimulando-se, sempre que possível, as adoções necessárias.

Sobre o tema manifesta-se Sávio Bittencourt, nos seguintes termos:

\begin{abstract}
Com o escopo de construir adoções seguras e propiciar para os interessados na paternidade socioafetiva a preparação psicológica e o estímulo às adoções necessárias, tornou-se obrigatória a participação dos postulantes em programa oferecido pela Justiça da Infância e da Juventude, sendo desejável que exista apoio dos técnicos responsáveis pela execução da política municipal de garantia do direito à convivência familiar para este esforço. A ideia é capacitar os pretendentes para as peculiaridades da paternidade adotiva e, se possível, abrir os horizontes destes para as crianças que têm mais dificuldades de encontrar postulantes interessados: crianças negras, crianças maiores ou adolescentes, com necessidades específicas de saúde ou com deficiências e grupos de irmãos (parágrafo $1^{\circ}$ do artigo 197-C).

Perdeu a oportunidade o legislador de corroborar o Plano Nacional de Convivência Familiar e Comunitária e incluir nesta importante preparação os Grupos de Apoio à Adoção, que já fazem voluntariamente este trabalho há mais de uma década e acumularam valiosa experiência. Todavia, se espera que o Poder Judiciário busque esta parceria em prol das crianças disponíveis para a adoção, demonstrando a maturidade necessária para tratar de questão social que requer o empenho solidário das instituições (...). ${ }^{229}$
\end{abstract}

No momento desta preparação psicológica, é importante que a equipe técnica, formada por psicólogos e assistentes sociais, verifique quais os motivos que levaram os interessados- sejam eles solteiros, casados ou companheiros- a adotar e o que estas pessoas esperam da adoção. Afinal, o conhecimento da motivação dos interessados pela equipe multidisciplinar possibilita a preparação adequada dos candidatos para a filiação afetiva e o ajuste de suas expectativas.

Caso a adoção seja conjunta, é importante que as duas pessoas estejam preparadas para assumir a filiação e que a sua motivação seja compatível. Afinal, a imposição da decisão de adotar a um dos membros do casal ou a incompatibilidade de motivação pode gerar conflitos insolúveis entre os interessados, prejudiciais à manutenção de um ambiente familiar sadio e equilibrado. Nesse sentido:

229 BITTENCOURT, Sávio. A Nova Lei de Adoção. Do Abandono à Garantia do Direito à Convivência Familiar e Comunitária. Rio de Janeiro: Lumen Juris, 2010. pp. 128-129. 


\begin{abstract}
A diferença de móvel interno entre os integrantes de um casal poderá acarretar conseqüências tais que demonstram ao juiz não ser aconselhável a deferimento da adoção. Isso ainda que, caso analisadas separadamente, como se de dois adotantes singulares potenciais se tratasse, os móveis internos de ambos mostrassem-se aptos ao deferimento da relação parental. Vale dizer: pode ser que o juiz, entrevistando o marido e percebendo o móvel que lhe anima o espírito em direção ao passo que está prestes a dar, convença-se da aptidão deste para adotar; da mesma forma, ao entrevistar a mulher, pode ele juiz mostrar-se absolutamente convencido de que os motivos que a animam são os mais lícitos, morais e aconselháveis possíveis. O problema se põe, portanto, é na verificação da conjugação de ambos os fatores e da previsão dos conflitos que podem daí advir. Inegável, assim, a importância da coadjuvação dos assistentes sociais, dos psicólogos forenses e demais auxiliares de que se possa o magistrado valer. Cabe a estes indicar os potenciais conflitos e conseqüências que possam advir. Caberá ao juiz analisá-los e dar aplicação ao princípio do melhor interesse da criança inscrito em nossa legislação interna por inspiração das posições assumidas pela comunidade internacional, ainda que para negar a adoção pretendida. Se, por outro lado, restar-lhe assente que os conflitos que daí advir não se diferenciariam em muito dos conflitos normalmente existentes entre os casais que decidem por uma gravidez, por exemplo, então o melhor é deferir a adoção, uma vez que se desprende da filosofia civil-constitucional o postulado de que as relações existentes entre os pais são de uma ordem e aquelas existentes entre os pais e os filhos são outras.
\end{abstract}

Diante do quadro acima, pode-se imaginar que a adoção conjunta é sempre mais delicada que a adoção singular, por envolver a conjugação da vontade de pessoas com expectativas e desejos diversos. Apesar de esta suposição ser razoável, não é menos verdade que a adoção singular também possui suas particularidades, merecendo análise detalhada dos psicólogos e assistentes sociais.

Afinal, por não ter um companheiro, alguém para dividir os ônus e bônus da paternidade/maternidade, é comum que o adotante deposite na criança todas as suas expectativas. Ademais, a construção ou a reconstrução da vida amorosa do adotante ficará na dependência da aceitação da pré-existência deste vínculo com a criança e do respeito pelos interesses da mesma, como bem lembrado pelo professor Gustavo Ferraz de Campos Mônaco. ${ }^{230}$

\footnotetext{
230 “(...) Num extremo oposto está a intenção do adotante singular que não mantém (mais ou ainda) uma relação amorosa e afetiva com a intenção de constituir uma família. Assim, os agentes sociais deverão ter em consideração não apenas a real intenção do (a) pretenso (a) adotante, como, ainda e principalmente, garantirem-se da real conscientização do (a) mesmo (a) no sentido de que a construção (para os solteiros que não possuem nenhuma espécie de união estável semelhável ao casamento) ou reconstrução (para os divorciados, viúvos ou aqueles que tenham rompido uma união estável) de sua vida amorosa e afetiva passará, inevitavelmente, pela pré-existência de uma prole que deverá ser aceita e respeitada por aquela pessoa que venha a triangular a relação de afeto familiar previamente constituída (família monoparental na origem)". (MÔNACO, Gustavo Ferraz de Campos. Motivação interna da decisão de adotar: adoção por casais e por pessoas singulares. Porto Alegre, Revista Brasileira de Direito de Família, v. 4, n. 14, pp.43-50, 2002).
} 
A verdade é que não existe, e nem deveria existir, uma regra enumerando os motivos válidos para adoção.

Muitos dos pretendentes chegam ao Poder Judiciário repletos de dúvidas, inseguranças e pré-conceitos, após um longo processo de desgaste, marcado por tentativas frustradas de gestação e pela cobrança familiar e social da maternidade/paternidade, sentindo-se culpados por serem incapazes de formar uma família.

As pesquisas acima mencionadas, porém, não adentram nos motivos que levam às pessoas a adotar uma criança. Na grande maioria das vezes, a adoção é uma opção para aqueles pais que não possuem condições de gerar um filho. Mas, mais importante que isso, a adoção é um ato de amor, uma opção consciente pela paternidade.

A adoção, apesar de movida pelo amor e pela vontade consciente de ser pai/mãe, não é uma escolha fácil. Muito pelo contrário, a adoção faz com que o interessado se questione sobre a viabilidade deste amor desvinculado de qualquer laço de sangue, e sobre seus próprios preconceitos. Nesse sentido, vale transcrever as observações de Elizabeth Bartholet:

O processo de adoção me forçou a pensar na discriminação em um nível pessoal. Quando você precisa preencher um formulário da agência de adoção a respeito das incapacidades que você poderia aceitar em uma criança- retardo mental, cegueira, ausência de rim, síndrome de Down- você passa a pensar sobre o significado de incapacidade de uma nova maneira. Se você escolhe a opção que diz "nenhuma das incapacidades anteriores", você é forçado a pensar sobre se o seu ato de discriminação é fundamentalmente o mesmo que aquele que exclui uma pessoa incapaz do mercado de trabalho. Se o seu objetivo é adotar uma criança saudável, como era o meu, você pode passar muitas horas se sentindo culpada e se questionando se esta atitude é consistente com a sua visão de si próprio como um ser humano amável e um possível pai adequado.

(...)

A adoção levantou questões assustadoras. Eu poderia amar uma criança que não foi parte de mim e não foi gerada pelo meu corpo? Eu poderia sentir o total comprometimento que associei com amor parental por uma criança que veio a mim como um estranho? Ou a forma de apego que eu vivenciei com meu primeiro filho era conseqüência da inevitabilidade biológica decorrente da progressão da relação sexual, que levou à gravidez e ao nascimento, e do vínculo genético entre a gente?

Eu descobri que o que conheço por amor parental é decorrência da experiência de cuidado, e que a paternidade adotiva é, em aspectos fundamentais, idêntica à paternidade biológica. Eu passei a encarar a gravidez e o parto como experiências que para mim foram extremamente gratificantes, mas que possuem relevância limitada no relacionamento parental. Eu não vejo os vínculos biológicos como totalmente irrelevantes para a paternidade, mas tampouco vejo 
um sistema de hierarquia entre a paternidade biológica e a adotiva (...). ${ }^{231}$ (grifo da autora)

Cabe, assim, à equipe técnica acalmar, estimular e alertar os interessados sobre a importância da filiação afetiva, ajustando as suas expectativas e evitando que eles tomem uma decisão por motivos puramente egoísticos. A compreensão das expectativas dos interessados e de sua vivência é fundamental para o sucesso da adoção.

Dessa maneira, resta plenamente possível, por meio do amparo da equipe profissional à disposição do Juízo, que a motivação e as expectativas dos interessados sejam adequadas às necessidades e ao perfil das crianças e dos adolescentes disponíveis para adoção. $^{232}$

231 "The adoption process also forced me to think on a personal level about discrimination. When you have to fill out a form for the adoption agency that asks what disabilities you could accept in a child-mental retardation, blindness, a missing limb, Down syndrome- you think about the meaning of disability in a new way. If you check the box on the bottom that says 'none of the above disabilities', you are pushed to think about whether your act of discrimination is fundamentally the same as or different from the act excluding a disabled person from employment or housing. If your goal is to adopt children who fall in the healthy infant' category, as my goal was, you may spend many guilty hours questioning whether this goal is consistent with your sense of yourself as a loving human being and a fit prospective parent. (...) Adoption posed terrifying questions. Could I love in the same way a child who had not been part of me and was not born from my body? Could I feel that totality of commitment I associated with parental love toward a child who came to me as a baby stranger? Or did the form of attachment I had known with my first child arise out of the biologic inevitability felt in the progression from sexual intercourse to pregnancy to childbirth, and out of the genetic link between us? I discovered that the thing I know as parental love grows out of the experience of nurturing, and that adoptive parenting is in fundamental ways identical to biological parenting. I have come to think of pregnancy and childbirth as experiences that for me were enormously satisfying but that seem of limited relevance to the parenting relationship. I do not see biologic links as entirely irrelevant to parenting, but neither do I see an obvious hierarchical system for ranking biologic and adoptive parenting (...)" (BARTHOLET, Elizabeth. Family Bonds: Adoption, Infertility, and the New World of Child Production. Boston: Beacon Press, 1999. pp. xx-xxii).

${ }^{232}$ Nas palavras de Lidia Natalia Dobrianskyj Weber, "Pesquisas com famílias adotivas (Eber, 1995 A, 1995 B, 1995 C; Weber 1996; Weber e colaboradores, 1994); (Weber e Cornélio, 1995 a e 1995 B) revelaram dados surpreendentes em relação à questão das 'motivações inadequadas ou adequadas para o exercício da paternidade adotiva'. A análise dos resultados mostrou que não existe correlação entre a motivação dos adotantes e o sucesso da adoção. Isso significa, grosso modo, que a construção do vínculo afetivo pode ser tão poderosa e importante na dinâmica familiar que deixa em segundo plano a inadequação do motivo inicial e outra história é capaz de ser construída posteriormente; exatamente o oposto que supõem muitos técnicos, ao afirmarem que 'a apreciação das motivações tem um interesse capital', pois 'é mais simples uma ligação com os filhos naturais do que com os filhos adotivos'. Para estes técnicos são consideradas não recomendáveis as motivações que resultam no risco da 'criança-distração', 'criança tábua-de-salvação', 'criança colocação' e ainda 'a atração neurótica por crianças deficientes'; outros técnicos afirmam que as famílias monoparentais e pessoas que podem ter filhos biológicos e optam por filhos adotivos também estariam em 'situação de risco'. Um casal que deseja adotar uma criança porque seu filho biológico faleceu pode parecer realmente inadequado. Os técnicos diriam que eles 'estão querendo substituir o filho falecido'. No entanto, é preciso levar em conta a capacidade de reconstrução de sua própria história, de construção do apego, do fascínio da capacidade de amar. Pode-se aprender que, na verdade, ninguém substitui ninguém e todo filho pode ter seu lugar no afeto dos pais. Se ninguém pode acessar a subjetividade do outro, e, muitas vezes, nem mesmo a própria pessoa, então os rótulos de nada valem, porque cada caso é um caso, ou seja, as pessoas não se comportam da mesma maneira nem mesmo em situações idênticas- as relações funcionais em cada situação é que são importantes: 'o vento é o mesmo, mas a sua resposta é diferente em cada folha', 
Neste contexto, é de suma importância que os psicólogos e assistentes sociais fiquem atentos ao perfil dos interessados, a fim de averiguar se eles terão condições de estimular as potencialidades das crianças envolvidas, proporcionando-lhes um desenvolvimento saudável e completo. Como bem lembrado por Françoise Dolto:

(...) Em que critérios se basear para estudar as candidaturas? É necessário basearse em critérios que levem em conta o que se deve fazer ou não quando se trata de entregar uma criança. Não se pode por uma criança que não tem ouvido, por exemplo, em uma família de músicos. Não se pode colocar uma criança muito imaginativa em casa de pais obsessivos e sem imaginação. Não se pode por uma criança que tenha sensibilidade, que seja fina e tenha potencialidades intelectuais ou artísticas em casa de alguém quadrado, rústico e pouco sensível. Seria uma loucura! Num caso assim, tudo o que a criança fizer ficará completamente aculturado, e isso pode torná-la perversa, porque não haverá potencialidade de escuta para ela. ${ }^{233}$

Isso não quer dizer, por óbvio, que os adotantes e os adotandos devam ser iguais em gostos, preferências e aptidões, mas é preciso que os interessados estejam abertos à diferença, que, de forma geral, é muito mais edificante que a igualdade. Deve-se lembrar, afinal, que adoção é uma forma de desenvolvimento recíproco dos adotantes e dos adotados.

Nesta linha de raciocínio e atentas à necessidade de integração familiar das crianças institucionalizadas, em sua grande maioria negra e mais velha, as equipes interprofissionais que atuam nas Varas da Infância e da Juventude, auxiliadas pelos Grupos de Apoio à Adoção, ${ }^{234}$ ao entrevistar e preparar os candidatos, buscam estimular as adoções inter-

ressalta sabiamente a poetisa Cecília Meireles. Este argumento nos faz entender que a prevenção é fundamental, mas também é preciso acreditar num trabalho a posteriori frente a estas 'inadequações'- o acompanhamento (WEBER, Lidia Natalia Dobrianskyj. Aspectos Psicológicos da Adoção. 2a ed. Curitiba: Juruá, 2011. pp. 36-37).

${ }^{233}$ DOLTO, Françoise. Destinos de crianças: adoção, famílias de acolhimento, trabalho social. São Paulo: Martins Fontes, 1998. p. 98.

234 (...) uma importante colaboração dos GAAs é a preparação de candidatos à adoção para o enfrentamento de questões particulares da paternidade socioafetiva, que tem por escopo garantir adoções emocionalmente mais seguras. A meta de evitar devolução de crianças e propiciar uma qualidade de vínculo afetivo com a superação de mitos e preconceitos tem sido noticiada em diversos municípios, nos quais atuam os GAAs. Ademais, o perfil dos adotantes brasileiros começa a se transformar, ainda que lentamente, a partir da compreensão de do vínculo adotivo como uma forma de viver o afeto em plenitude, afastando-se a prisão ideológica do amor vinculado aos laços de sangue. O trabalho dos grupos tem sido decisivo para propiciar aos candidatos possibilidade de reflexões sobre o perfil da criança desejada, possibilitando a opção madura por crianças que estão fora do padrão tradicionalmente desejado. Ainda não há pesquisas que possa colaborar com esta impressão, mas os GAAs colecionam casos concretos de pessoas que procurando a adoção para imitar uma filiação biológica tanto quanto possível, mudam seu paradigma e adotam crianças fora do perfil inicialmente planejado, realizando as chamadas adoções necessárias (inter-raciais, de crianças mais velhas, de grupos de irmãos ou de crianças com deficiência) (BITTENCOURT, Sávio. A Nova Lei de Adoção. Do Abandono à Garantia do Direito à Convivência Familiar e Comunitária. Rio de Janeiro: Lumen Juris, 2010. p. 23). 
raciais e tardias, demonstrando que a filiação afetiva ultrapassa as barreiras da cor e da idade.

É dever das equipes técnicas informar aos pretendentes que a adoção não tem o condão de imitar a família biológica, sendo irrelevante que o adotando possua as mesmas características genéticas dos adotantes. A filiação adotiva se forma a partir de laços de amor e não de sangue, sendo salutar que os interessados se desapeguem da concepção biológica da paternidade.

Uma vez que os interessados tiverem consciência das peculiaridades da filiação adotiva e deixarem de lado a intenção de imitar a família biológica, as suas possibilidades e o seu horizonte se ampliarão, tornando a adoção inter-racial, muitas vezes também tardia, mais viável e atraente.

Ressalte-se, ademais, que o amparo psicológico e social não deve se restringir apenas ao curso do processo judicial de adoção. É essencial que os pais que tiveram a medida deferida e as crianças contempladas sejam amparados pela equipe interprofissional, permitindo a adaptação e a formação dos vínculos de afeto entre os envolvidos.

Apesar de todo o suporte oferecido pelo Poder Judiciário no curso da adoção, é comum que os pais se sintam inseguros quando recebem as crianças em suas casas, de forma definitiva, tendendo a superprotegê-las, com medo de perdê-las.

Dessa maneira, os pais adotivos devem ser orientados a agir com firmeza e amor na criação de seu filho, não cedendo às pirraças e chantagens emocionais da criança, que fará de tudo para testar o afeto e a vontade dos interessados em mantê-las em sua companhia, de forma permanente. Nesse sentido:

O filho precisa de exemplo e firmeza de posicionamento do pai. Já se disse que a palavra convence e o exemplo arrasta. Se a adoção estiver bem resolvida na vida do pai, e ele se comporta de forma a demonstrar isto, a compreensão e aceitação da verdade adotiva por parte do filho será muito facilitada. Assim, o pai deve exercer sua autoridade de forma equilibrada, exigindo do filho o cumprimento de tarefas e tomando as atitudes de coerção de comportamentos inadequados. 
Desembaraço para lidar com as pirraças, as impertinências e os equívocos do filho, demonstra que o pai não tem nenhum bloqueio pelo fato de se tratar de um vínculo adotivo. O que não é recomendável é se tratar a criança com pena por ela ser adotiva, pois é uma atitude preconceituosa e deseducadora. Mimar o filho em função de ele ser adotivo, não o corrigindo, "passando a mão na cabeça", simplesmente o transforma numa vítima de uma lesão imaginária e demonstra que o pai não acredita que a sua filiação seja tão importante e digna de respeito quanto a biológica. Em qualquer criação a presença dos pais como mediadores da adaptação do filho ao mundo é fundamental. Abdicar-se deste direito-dever pode significar abrir a porta para a entrada dos desvios de comportamento mais graves. $^{235}$ (grifo do autor)

Ressalte-se, aliás, que, ademais de estimular as adoções necessárias e preparar os candidatos para a filiação afetiva, o amparo psicológico dos pretendentes desempenha importante papel na manutenção dos vínculos estabelecidos entre os adotantes e os adotados, evitando a devolução ${ }^{236}$ de crianças aos abrigos e instituições de onde foram retiradas, quando da fixação do estágio de convivência ou da concessão final da medida.

Apesar de a lei dispor que a adoção é um ato irrevogável, é comum que os adotantes, quando se deparam com as dificuldades da filiação e com os desafios apresentados pela adoção (em especial a tardia), optem pela devolução do adotado, em clara violação aos deveres inerentes ao poder familiar.

Neste contexto, a equipe multidisciplinar desempenha papel fundamental na conscientização dos pretendentes à adoção, diminuindo os riscos de arrependimento e devolução das crianças adotadas, nos termos da lição da doutrina:

\footnotetext{
235 SILVA, Sávio Renato Bittencourt Soares. Guia do Pai Adotivo. Orientações para uma Adoção Feliz. $2^{\mathrm{a}}$ ed. Curitiba: Juruá, 2012. p. 53.

${ }^{236}$ Sobre a devolução de crianças, verificar a lição de Lidia Natalia Dobrianskyj Weber: "Devolução é uma palavra ampla e generalizada para este fenômeno e contempla pelo menos dois casos distintos: a 'interrupção' e a 'dissolução'. A literatura internacional denomina 'interrupção' da adoção quando os adotantes desistem de completar o processo antes de a adoção ser legalmente efetivada (esse período de efetivação não ultrapassa seis meses em países desenvolvidos, diferentemente do Brasil em que, às vezes, levam-se anos para que a família tenha de fato os papéis da adoção após o início da convivência...). Fala-se em 'rompimento' ou 'dissolução' quando ocorre a entrega da criança após a adoção efetivada e legalizada. O segundo caso é mais grave porque entende-se que houve maior tempo de convívio e, portanto, maior dor acarretará para os envolvidos, em especial a criança ou o adolescente. No Brasil não existem estatísticas precisas sobre a situação (mais estatísticas que faltam em nosso país...), mas dados americanos (o povo que mais faz adoções no mundo) mostram uma média de $3 \%$ a $12 \%$ de interrupções nas adoções; quando se analisam os dados apenas nas adoções tardias (adolescentes de 12 a 17 anos) o percentual pode subir para 25\% de interrupções. Nos Estados Unidos, mesmo se a família solicitar a anulação da adoção, ou seja, a dissolução, ela continua responsável pela criança ou adolescente mesmo que ela vá morar com outra família paga (sistema de fostercare, em países desenvolvidos não existem instituições), sendo que o sistema legal ainda tenta a reconciliação por meio de aconselhamento profissional (...) (WEBER, Lidia Natalia Dobrianskyj. Prefácio. In SOUZA, Hália Pauliv de. Adoção Tardia. Devolução ou Desistência de um Filho? A Necessária Preparação para a Adoção. Curitiba: Juruá, 2012. p. 13).
} 
Quanto ao sucesso obtido na reintegração familiar ou adaptação à família substituta, tema bastante atual e que merece discussão é o problema da devolução de crianças adotadas. Conforme pesquisa realizada pela psicanalista Maria Luiza Ghirardi, pelo Instituto de Psicologia da Universidade de São Paulo (USP), os pais adotivos encontram várias dificuldades após a adoção, especialmente porque tendem a idealizar uma relação perfeita com os filhos. Uma solução para evitar os problemas das devoluções seria o da preparação prévia dos pais adotivos sobre o significado da adoção, seu caráter irrevogável e o conhecimento de seus próprios sentimentos em relação à adoção. Um acompanhamento próximo e a ajuda de profissionais, no período posterior à adoção, também seriam de extrema importância para auxiliar na solução de possíveis conflitos. $^{237}$

Com a finalidade de desestimular este tipo de comportamento e conscientizar os interessados dos deveres que lhes são impostos com a concessão da adoção, o Tribunal de Justiça do Estado de Minas Gerais reconheceu a responsabilidade dos adotantes pelo pagamento de indenização por danos materiais (pensão alimentícia) e morais ao adotando, em caso de desistência da adoção e devolução do menor, nos seguintes termos:

\begin{abstract}
Ação Civil Pública. Indenização. Danos morais e materiais. Adoção. Devolução de menor. Responsabilidade civil dos pais adotivos configurada. Tendo os pais adotivos abandonado o menor, devolvendo-o ao abrigo, não tendo demonstrado sequer um mínimo de esforço para se reaproximarem da criança, patente o dever de indenizar, não só porque o filho foi privado do convívio de seus pais, mas primordialmente de sua irmã de sangue de quem sente muita saudade. Negligenciando os requeridos na criação e educação do adotado, mormente, por terem ciência de que a adoção só foi concedida para possibilitar o convívio dos irmãos, ferindo, assim, o princípio constitucionalmente assegurado da dignidade da pessoa humana, cabe-lhe indenizar a criança pelos danos sofridos (Apelação cível n. 12.0702.09.568648-2/002, $8^{\mathrm{a}}$ Câmara Cível, TJMG, Relatora Desembargadora Teresa Cristina da Cunha Peixoto, j. 10.11.2011).
\end{abstract}

Vale lembrar que, uma vez consumada a adoção, os pais adotivos possuem as mesmas responsabilidades que os biológicos, devendo zelar pela criação, cuidado e educação de seus filhos. Em razão disso, a devolução de crianças adotadas a abrigos e instituições configura abandono material e intelectual, sujeitando-se os seus genitores às consequências penais e civis de seu ato.

Frise-se, por fim, que a devolução acarreta consequências extremamente danosas às crianças adotadas ou em processo de adoção, uma vez que representa mais um abandono em sua curta existência e pode dificultar, sobremaneira, a sua recolocação em família substituta. Em virtude disso, os interessados devem ter a consciência de que seus atos são

${ }^{237}$ RIBEIRO, Paulo Hermano Soares; SANTOS, Vívian Cristina Maria; SOUZA, Ionete de Magalhães. Nova Lei de Adoção Comentada. 2a ed. Leme: J.H.Mizuno, 2012. p. 225. 
capazes de causar prejuízos irreparáveis ao desenvolvimento da criança, evitando encarar a adoção como um mero capricho.

\subsection{A educação em direitos humanos como mecanismo de esclarecimento e de estímulo às adoções inter-raciais e tardias}

Assim como o amparo psicológico aos envolvidos no processo de adoção interracial, a educação em direitos humanos é fundamental para o sucesso da medida.

O direito à educação, em sentido lato, está longe de ser uma preocupação recente. Suas raízes remontam ao século XVIII, mais especificamente à Revolução Francesa.

A Declaração dos Direitos do Homem e do Cidadão, aprovada pela Convenção Nacional Francesa em 1793, dispôs sobre a relevância da educação (instrução) em seu art. XXII, nos seguintes termos: a instrução é a "necessidade de todos. A sociedade deve favorecer com todo o seu poder o progresso da inteligência pública e colocar a instrução ao alcance de todos os cidadãos".

Na mesma linha de raciocínio, a Declaração Universal dos Direitos Humanos, proclamada pela Assembleia Geral da Organização das Nações Unidas (ONU), em 10 de dezembro de 1948, reafirmou, no seu artigo XXVI, que:

Toda pessoa tem direito à instrução. A instrução será gratuita, pelo menos nos graus elementares e fundamentais. A instrução elementar será obrigatória. A instrução técnico-profissional será acessível a todos, bem como a instrução superior, esta baseada no mérito.

Estes dispositivos serviram de inspiração para as Constituições brasileiras, em especial para a Constituição vigente (1988), que prevê o direito à educação como direito fundamental, ${ }^{238}$ de natureza social ${ }^{239}$ e estabelece que a educação básica é obrigatória e

\footnotetext{
238 Artigo 6 ${ }^{\circ}$. "São direitos sociais a educação, a saúde, a alimentação, o trabalho, a moradia, o lazer, a segurança, a previdência social, a proteção à maternidade e à infância, a assistência aos desamparados na forma desta Constituição".

239 “Assim, podemos dizer que os direitos sociais, como dimensão dos direitos fundamentais do homem, são prestações positivas proporcionadas pelo Estado direta ou indiretamente, enunciadas em normas constitucionais, que possibilitam melhores condições de vida aos mais fracos, direitos que tendem a realizar a igualização de situações sociais desiguais. São, portanto, direitos que se ligam ao direito de igualdade. Valem como pressupostos do gozo dos direitos individuais, na medida em que criam condições materiais mais propícias ao auferimento da igualdade real, o que, por sua vez, proporciona condição mais compatível com o
} 
gratuita, permitindo o seu acesso a todos, independentemente de suas condições pessoais e/ou econômicas.

A educação, dever do Estado e da família, é norteada pelos princípios da igualdade de condições para acesso e permanência na escola, da liberdade de ensino e de divulgação do pensamento, da garantia do padrão de qualidade, dentre outros. Nesse sentido:

Art. 205. A educação, direito de todos e dever do Estado e da família, será promovida e incentivada com a colaboração da sociedade, visando ao pleno desenvolvimento da pessoa, seu preparo para o exercício da cidadania e sua qualificação para o trabalho.

Art. 206. O ensino será ministrado com base nos seguintes princípios:

I - igualdade de condições para o acesso e permanência na escola;

II - liberdade de aprender, ensinar, pesquisar e divulgar o pensamento, a arte e o saber;

III - pluralismo de idéias e de concepções pedagógicas, e coexistência de instituições públicas e privadas de ensino;

IV - gratuidade do ensino público em estabelecimentos oficiais;

V - valorização dos profissionais da educação escolar, garantidos, na forma da lei, planos de carreira, com ingresso exclusivamente por concurso público de provas e títulos, aos das redes públicas;

VI - gestão democrática do ensino público, na forma da lei;

VII - garantia de padrão de qualidade.

VIII - piso salarial profissional nacional para os profissionais da educação escolar pública, nos termos de lei federal.

Parágrafo único. A lei disporá sobre as categorias de trabalhadores considerados profissionais da educação básica e sobre a fixação de prazo para a elaboração ou adequação de seus planos de carreira, no âmbito da União, dos Estados, do Distrito Federal e dos Municípios.

Neste contexto, cumpre mencionar que a universalização da educação, apesar de ser obtida por meio do princípio da igualdade de condições de acesso e de permanência na escola, só é eficaz e com qualidade quando respeitada a diversidade. Dessa maneira, a igualdade e a diferença devem conviver de forma harmônica, ${ }^{240}$ a fim de que o direito à educação seja alcançado nos moldes previstos pela Constituição Federal. ${ }^{241}$

exercício efetivo da liberdade" (SILVA, José Afonso da. Curso de Direito Constitucional Positivo. $37^{\mathrm{a}}$ ed. São Paulo: Malheiros, 2014. pp. 288-289).

${ }^{240}$ A harmonia entre a igualdade e a diferença se dá, muitas vezes, através da adoção de políticas afirmativas, pautadas no princípio da distribuição. Nesse sentido: “O princípio da redistribuição serve de base a um direito à redistribuição, tanto por políticas universalistas quanto por políticas afirmativas, por ter como fundamento um elenco amplo e diversificado de deveres constitucionais. Esses deveres não se restringem à promoção da educação para todos. Abarcam também resultados dessa educação, demandando uma educação que se volte ao pleno desenvolvimento da pessoa, que seja diversa, que compense por discriminações passadas e que provoque um melhora no status social de cada indivíduo" (IKAWA, Daniela. Direito às Ações Afirmativas em Universidades Brasileiras. In SARMENTO, Daniel; IKAWA, Daniela; PIOVESAN, Flávia. Igualdade, Diferença e Direitos Humanos. Rio de Janeiro: Lumen Juris, 2010. p. 374).

${ }^{241}$ Nesse sentido, conferir WEINGARTNER NETO, Jayme e SARLET, Ingo Wolfgang: “A educação (abrangendo ensino e pesquisa) e a formação para uma vida com dignidade e, neste contexto, uma educação 
Vale lembrar que esta compatibilização entre a igualdade e a diferença pode ser obtida por meio da educação intercultural, que pressupõe um processo dinâmico e contínuo com as seguintes fases: (1) desconstrução: é preciso conhecer os preconceitos e as causas da discriminação, com a finalidade de reavaliar os currículos e programas escolares e pôr fim ao caráter monocultural do ensino; (2) articulação: deve haver uma articulação entre a igualdade e as diferenças das políticas educativas e práticas pedagógicas, permitindo a valorização cultural e o reconhecimento da diversidade; (3) resgate: retomada dos processos de construção das identidades culturais, individuais e coletivas. Este aspecto se relaciona com o diálogo entre os diferentes saberes; (4) promoção: estímulo de interação, como mecanismo de valorização de outras culturas e saberes e de reconstrução do conhecimento. ${ }^{242}$

Ressalte-se que pesquisas comprovam que o rendimento escolar dos alunos que são vítimas de desigualdades regionais, culturais e linguísticas é mais baixo que o dos alunos que não enfrentam a mesma situação, sendo imprescindível que as escolas estabeleçam conteúdos programáticos diferenciados para cada região do país, levando-se em consideração o perfil e as peculiaridades dos seus educandos. ${ }^{243}$

para os direitos humanos e fundamentais, constitui tarefa (dever constitucional) irrenunciável do Estado e da Sociedade, no âmbito de todas as suas unidades, sendo mesmo possível afirmar que a educação para os direitos humanos e fundamentais integra o que se tem designado de um mínimo existencial sociocultural. Mas, como já foi, aliás, objeto de longa digressão, o Estado deve- como Estado Democrático de Direitogarantir e promover a liberdade e a proteção dos bens e direitos culturais simultaneamente, resistindo às tentações totalitárias da 'instrumentalização' e da 'programação' cultural, daí a já enfatizada necessidade de preservar o pluralismo e assegurar o reinado da tolerância, o que desafia o que se poderia designar de uma 'separação cultural' de poderes. Com efeito, se no que diz com a aplicação do princípio da dignidade da pessoa humana já se apontou, à vista dos excessos ou menoscabos, para uma tirania da dignidade, mais cuidado ainda para com os riscos de uma tirania dos valores e da cultura no campo da educação em geral, bem como na esfera do ensino e da pesquisa jurídica em particular" (WEINGARTNER NETO, Jayme; SARLET, Ingo Wolfgang. Dignidade (da Pessoa) Humana e Fundamentais e Ensino Jurídico: Algumas Aproximações. In NALINI, José Renato; CARLINI, Angélica. Direitos Humanos e Formação Jurídica. Rio de Janeiro: Forense, 2010. p. 421).

${ }^{242}$ Nesse sentido: CANDAU, Vera Maria. Direitos humanos, educação e interculturalidade: as tensões entre igualdade e diferença. Revista Brasileira de Educação, v. 13, n. 37, pp.53-54, jan./abr. 2008.

${ }^{243} \mathrm{O}$ site www.objetivosdomilenio.org.br traz uma lista de casos de voluntariados, que se destinam ao alcance da educação universal e de qualidade. Como exemplo, pode-se citar a Associação Vaga Lume, "entidade civil que tem como missão promover o desenvolvimento cultural e educacional de comunidades rurais da Amazônia Legal Brasileira e contribuir para a integração da Amazônia com as demais regiões do país". Referida associação possui dois programas: (a) a Expedição Vaga-lume, que busca promover a criação de bibliotecas comunitárias, vistas como centros irradiadores de conhecimento, cultura, educação, articulação e organização comunitária e (b) a Rede dos Vaga-lumes, encarregada de promover o intercâmbio cultural entre as comunidades escolares urbanas e rurais. De acordo com as informações constantes do site, a intervenção da Associação Vaga-lumes tem como objetivos (a) formar professores e comunitários como mediadores de leitura; (b) estimular exercícios de gestão comunitária de bibliotecas e ações que facilitem o envio de livros para a região amazônica e (c) monitorar ações desenvolvidas nas bibliotecas implantadas pela Associação. 
Nesta linha de raciocínio, vale transcrever a lição de Adelaide Alves Dias: ${ }^{244}$

Se tranversalizarmos os dados estatísticos até aqui apresentados sobre rendimento escolar, veremos que eles são mais desfavoráveis entre aqueles que são vítimas das desigualdades regionais, culturais e lingüísticas no nosso país. Assim, por exemplo, com relação ao ensino fundamental, as taxas de repetência concentram seus mais altos índices nas regiões Norte e Nordeste, 15,8\% e 16,3\% respectivamente. Igual realidade pode ser constatada com relação à taxa de evasão/abandono: $11,1 \%$ para a região Norte e 12,3\% para o Nordeste. Inversamente, estas regiões possuem as menores taxas de aprovação no ensino fundamental do país - 73,1\% e 71,4\%, respectivamente. (INEP, Sinopse estatística do Censo Escolar, 2006). Os mesmos dados relativos ao ensino médio, mostram sua face mais cruel: o índice de abandono/evasão supera os $20 \%$ nas citadas regiões, acompanhado pela menor taxa de aprovação, em torno de pouco mais de $70 \%$.

Isto significa que a problemática da igualdade do acesso à escola não pode ser confundida como expressão de uma cultura homogênea, de padrão único. Faz-se necessário a adoção de currículos e metodologias de ensino que levem em consideração as diferenças regionais, culturais, de gênero, étnicas, raciais e religiosas, os perfis populacionais etários e os contextos onde as aprendizagens se realizam.

Os estudos sobre o multiculturalismo têm revelado que a nossa identidade é plural, marcada pelo nosso pertencimento aos mais variados grupos sociais e, que, portanto, precisamos tratar nossas diferenças com o devido respeito e tolerância necessários ao convívio escolar democrático, acolhedor, humano.

Dessa maneira, o respeito dos educandos e dos educadores às diferenças de raça, cor, sexo, credo e opinião dos envolvidos no processo de transmissão do conhecimento e daqueles por ele atingidos (direta ou indiretamente) precisa estar englobado no próprio objeto da educação, que há de envolver não apenas a transmissão de conhecimentos científicos, como também de valores.

Neste contexto, desempenha papel fundamental a educação em direitos humanos, prevista pela Declaração de Viena, de 1993, como mecanismo de promoção da paz, da tolerância e do respeito mútuo, nos seguintes termos:

33. A Conferência Mundial sobre Direitos Humanos reafirma que os Estados estão vinculados, conforme previsto na Declaração Universal dos Direitos do Homem, no Pacto Internacional sobre os Direitos econômicos, Sociais e Culturais e noutros instrumentos internacionais de Direitos Humanos, a garantir que a educação se destine a reforçar o respeito pelos Direitos Humanos e liberdades fundamentais. A Conferência Mundial sobre Direitos Humanos realça a importância de incluir a questão dos Direitos Humanos nos programas de educação e apela aos Estados para o fazerem. A educação deverá promover a compreensão, a tolerância, a paz e as relações amistosas entre as nações e todos

244 DIAS, Adelaide Alves. Da educação como direito humano aos direitos humanos como princípio educativo. In SILVEIRA, Rosa Maria Godoy et al (org.). Educação em Direitos Humanos. Fundamentos teórico-metodológicos. João Pessoa: Editora Universitária/UFPB, 2007. pp. 451-452. 
os grupos raciais ou religiosos, e encorajar o desenvolvimento de atividades das Nações Unidas na prossecução destes objetivos. Assim, a educação em matéria de Direitos Humanos e a divulgação de informação adequada, tanto teórica como prática, desempenham um papel importante na promoção e no respeito dos Direitos Humanos em relação a todos os indivíduos, sem distinção de qualquer tipo, nomeadamente de raça, sexo, língua ou religião, devendo isto ser incluído nas políticas educacionais, quer a nível nacional, quer internacional. A Conferência Mundial sobre Direitos Humanos observa que as limitações de recursos e a falta de adequação das instituições podem impedir a imediata concretização destes objetivos.

\title{
A leitura do trecho da Declaração de Viena demonstra que a educação em direitos
} humanos, assim como a educação em sentido lato, deve se dar no campo formal e informal, ${ }^{245}$ de modo a propiciar que todos os indivíduos exercitem a sua cidadania com dignidade e respeito ao próximo.

\section{De acordo com o Plano Nacional de Educação em Direitos Humanos, a transmissão} e a absorção de conhecimento não ocorrem apenas no ambiente escolar. A educação nãoformal, que pode se dar em diferentes dimensões, públicas e/ou privadas, tem como finalidade promover a divulgação do conhecimento popular e a participação em ações coletivas, de forma dialógica e integradora. Nesse sentido:

\begin{abstract}
A humanidade vive em permanente processo de reflexão e aprendizado. Esse processo ocorre em todas as dimensões da vida, pois a aquisição e produção de conhecimento não acontecem somente nas escolas e instituições de ensino superior, mas nas moradias e locais de trabalho,nas cidades e no campo, nas famílias, nos movimentos sociais, nas associações civis, nas organizações nãogovernamentais e em todas as áreas da convivência humana. A educação nãoformal em direitos humanos orienta-se pelos princípios da emancipação e da autonomia. Sua implementação configura um permanente processo de sensibilização e formação de consciência crítica, direcionada para o encaminhamento de reivindicações e a formulação de propostas para as políticas
\end{abstract}

\footnotetext{
245 “Existem muitas instituições, culturas e práticas por meio das quais as diferentes sociedades educam suas crianças e jovens. Podemos dizer que existe um 'sistema informal' de educação que é formado pelas instâncias de socialização, de criação e de treinamento que as pessoas recebem dos seus pais e de suas famílias, ou de outros membros de sua comunidade, de empregadores, da mídia, de grupos sociais a que pertencem, e da própria escola enquanto um espaço público responsável também pela socialização das pessoas. Essa educação informal pode nos deixar alguns aprendizados muito importantes para nossa vida. É 'vivendo a vida' que aprendemos as lições mais importantes de como devemos nos relacionar com as outras pessoas e de quais valores e princípios tornam essa vida social possível.Por isso é que se as pessoas vivem em uma sociedade onde o autointeresse é mais importante do que o cuidado pelo próximo, onde as injustiças sociais são ignoradas, gerando frustrações, onde a violência é vista como o método padrão de resolução de conflitos, é natural que suas crianças e jovens sejam treinados a viver esses valores como parte de sua educação informal.Por outro lado, o 'sistema formal' de educação inclui escolas públicas e privadas e universidades. Há sempre uma esperança de que as escolas possam reparar qualquer má promoção de valores feita pelo sistema informal. Se as famílias e comunidades são incapazes de cultivar os valores e os comportamentos de que a sociedade necessita para o seu bom funcionamento, então volta-se às escolas para a reparação dessa falha" (ONU. Programa das Nações Unidas para o Desenvolvimento. Relatório de Desenvolvimento Humano Brasileiro 2009/2010. p. 146).
} 
públicas, podendo ser compreendida como: a) qualificação para o trabalho; b) adoção e exercício de práticas voltadas para a comunidade; c) aprendizagem política de direitos por meio da participação em grupos sociais; d) educação realizada nos meios de comunicação social; e) aprendizagem de conteúdos da escolarização formal em modalidades diversificadas; e f) educação para a vida no sentido de garantir o respeito à dignidade do ser humano.

Os espaços das atividades de educação não-formal distribuem-se em inúmeras dimensões, incluindo desde as ações das comunidades, dos movimentos e organizações sociais, políticas e não governamentais até as do setor da educação e da cultura. Essas atividades se desenvolvem em duas vertentes principais: a construção do conhecimento em educação popular e o processo de participação em ações coletivas, tendo a cidadania democrática como foco central.

Nesse sentido, movimentos sociais, entidades civis e partidos políticos praticam educação não formal quando estimulam os grupos sociais a refletirem sobre as suas próprias condições de vida, os processos históricos em que estão inseridos e o papel que desempenham na sociedade contemporânea. Muitas práticas educativas não-formais enfatizam a reflexão e o conhecimento das pessoas e grupos sobre os direitos civis, políticos, econômicos, sociais e culturais. Também estimulam os grupos e as comunidades a se organizarem e proporem interlocução com as autoridades públicas, principalmente no que se refere ao encaminhamento das suas principais reivindicações e à formulação de propostas para as políticas públicas. ${ }^{246}$

Dessa maneira, a educação em direitos humanos, mais do que conscientizar o aluno de seus direitos fundamentais, tem como finalidade demonstrar a importância do respeito ao próximo, em especial pela valorização de sua opinião.

Frise-se que esta modalidade de educação diz respeito não somente ao conteúdo da instrução, mas principalmente à forma pela qual os ensinamentos são transmitidos e trocados. Educar em e para os direitos humanos significa, sobretudo, transmitir conhecimentos de forma dialógica, em respeito às opiniões dos alunos e às suas diferenças culturais, étnicas, raciais e religiosas. ${ }^{247} \mathrm{O}$ educador passa a ser um mediador, permitindo que o aluno construa e reconstrua o seu conhecimento. ${ }^{248}$

${ }^{246}$ BRASIL. Comitê Nacional de Educação em Direitos Humanos. Plano Nacional de Educação em Direitos Humanos. Brasília: Secretaria Especial dos Direitos Humanos, 2007. p. 43.

${ }^{247}$ Especificamente no que diz respeito à inclusão dos negros em universidades, sustenta Daniela Ikawa que: “A inclusão implica ainda uma consideração da igualdade de respeito (respeito na primeira acepção) do outro em um grau que possibilite o diálogo e a efetiva participação no ambiente objeto da inclusão. A inclusão abarca uma ideia de participação que pode ser estimulada na universidade pela adoção de tutorias extracurriculares, de acompanhamento pedagógico e eventualmente psicológico (em decorrência da pressão pela discriminação racial), pelo oferecimento de bolsas, e pela adoção de programas que envolvam a participação de brancos e negros com o intuito de provocar uma maior compreensão das diferenças estigmatizantes em status, dentre outras medidas" (IKAWA, Daniela. Direito às Ações Afirmativas em Universidades Brasileiras. In SARMENTO, Daniel; IKAWA, Daniela; PIOVESAN, Flávia. Igualdade, Diferença e Direitos Humanos. Rio de Janeiro: Lumen Juris, 2010. pp. 378-379).

${ }^{248}$ Neste sentido, conferir GADOTTI, Moacir. A questão da educação formall não-formal. Disponível em <www.virtual.ufc.br>. “(...) o professor é muito mais um mediador do conhecimento, diante do aluno que é o sujeito de sua própria formação. O aluno precisa construir e reconstruir conhecimento a partir do que faz. Para isso o professor também precisa ser curioso, buscar sentido para o que faz e apontar novos sentidos para o que fazer dos seus alunos. Ele deixará de ser um lecionador para ser um organizador do conhecimento e da aprendizagem. O professor se tornou um aprendiz permanente, um construtor de 


\section{Como bem lembrado pela doutrina:}

Educar para os direitos humanos prescinde, então, de uma escuta sensível e de uma ação compartilhada entre professores e alunos, capaz de desencadear processos autônomos de produção de conhecimento.

A produção do conhecimento socialmente relevante traz em seu escopo o necessário compromisso com a autonomia do pensamento. A conscientização, da qual falava Paulo Freire, é um importante vetor de oxigenação das práticas educativas que devam ser efetivadas em ambientes escolares ou não. A consciência do ser-no-mundo se mostra como uma ferramenta que possibilita a construção de sujeitos sociais críticos e atuantes em uma determinada sociedade, cônscios de seu inacabamento e, por isso mesmo, capazes de serem protagonistas de sua própria história.

Saberes construídos da contextualização e problematização de uma dada realidade, baseados em relações horizontais de ensino-aprendizagem, mediante as quais educador e educando se formam e se transformam, se criam e se recriam, conferem autonomia ao pensamento de ambos.

Tal construção de saberes, oriundos da práxis, mediatizados pela realidade histórica, social e cultural, consegue fazer com que educadores e educandos libertem-se de seus próprios pré-conceitos, pré-noções, pré-juízos.

É na relação que o sujeito contrai com os valores que a cultura e a sociedade definem para si mesmas, que a ação educativa se efetiva. A idéia do respeito ao saber do outro, só possível mediante práticas educativas dialógicas, traz consigo a possibilidade de, juntos, educadores e educandos construírem processos de emancipação humanos que repercutem em seus modos de sentir, de pensar e de agir frente ao mundo, aos outros sociais e a si próprios.

Em conclusão, podemos aduzir que a garantia do direito à educação, enquanto direito humano fundamental, percorre um caminho marcado por inúmeros sujeitos sociais: pelas lutas que afirmam esse direito, pela responsabilidade do Estado em prover os meios necessários à sua concretização e pela adoção de concepção de uma educação cujo princípio de igualdade contemple o necessário respeito e tolerância à diversidade.

Educar para os direitos humanos é, antes de tudo, assumir a postura de dialogia que mobiliza uma teia de relações intersubjetivamente formadas a partir da qual educadores e educandos negociam a definição das situações sociais, tendo como elemento mediador seus próprios saberes.

Tal noção de educação para os direitos humanos guarda íntima conexão com os ideais de democracia, cidadania, paz e justiça social, tão caros aos que militam pelos direitos humanos no nosso país. ${ }^{249}$

Percebe-se, assim, que a educação deve ser vista de forma ampla, de modo a abranger a educação em direitos, a transmissão de valores, o respeito ao outro e às diferenças. Enfim, o educador deve se preocupar não somente com a transmissão de

sentidos, um cooperador, e, sobretudo, um organizador da aprendizagem. É aquele que "cuida" da aprendizagem. O 'cuidado' (Boff, 1999) é uma categoria essencial na tarefa de educador. Não se trata do cuidado no sentido assistencial, mas do cuidado no sentido da atenção e da responsabilidade ético-políticado educador. De nada adiantará ensinar, se os alunos não conseguirem organizar o seu trabalho, serem sujeitos ativos da aprendizagem, auto-disciplinados, motivados. E não é suficiente oportunizar o acesso e a permanência na escola para todos: o direito à educação implica o direito de aprender".

249 DIAS, Adelaide Alves. Da educação como direito humano aos direitos humanos como princípio educativo. In SILVEIRA, Rosa Maria Godoy et al (org.). Educação em Direitos Humanos. Fundamentos teórico-metodológicos. João Pessoa: Editora Universitária/UFPB, 2007. pp. 453-454. 
conhecimentos científicos (ensino e pesquisa), mas também e principalmente com a formação do caráter dos indivíduos, por meio da transmissão de valores. ${ }^{250}$

Em virtude deste amplo perfil da educação, é importante que as instituições de ensino estejam atentas para as múltiplas oportunidades de aprendizagem, incluindo na sua rotina atividades internas e externas, que exijam interação pessoal, social, humana e com a natureza.

Conforme bem lembrado pela professora Eunice Aparecida de Jesus Prudente, a educação é fundamental não apenas para o pleno desenvolvimento do indivíduo, como também para o exercício dos seus direitos políticos. Em razão disso, a formação deve compreender: (1) a valorização pessoal; (2) o conhecimento da própria História; (3) a percepção das diferenças naturais; (4) a visão holística do Direito; (6) a recepção da opinião do outro; (7) a informação e organização política e (8) a participação política efetiva. ${ }^{251}$

Atenta à relevância da educação para a formação do indivíduo e para a evolução da sociedade, a Organização das Nações Unidas, em 2000, estabeleceu dentre os Oito Objetivos do Milênio- ODM a educação básica de qualidade para todos.

Feitas estas considerações, torna-se possível compreender a relevância do papel que a educação ocupa no combate contra o racismo e a discriminação e, consequentemente, na

\footnotetext{
${ }^{250}$ Conforme mencionado por Margarida Pedreira Bulhões Genevois, “A Educação em Direitos Humanos objetiva formar a consciência do indivíduo para que ele seja o sujeito de sua própria história; visa incutir o ideal de uma sociedade justa e democrática, o espírito de tolerância e a fraternidade ao mesmo tempo em que a determinação de lutar pelos que não têm direitos. Os Direitos Humanos não se aprendem nas salas de aula, mas permeiam todos os momentos da vida, e os atos do cotidiano; a Educação em Direitos Humanos visa criar um 'estado de espirito' de permanente vigilância. Não se trata de criar uma matéria sobre Direitos Humanos no programa escolar reservando um período para ensiná-las. Direitos Humanos não se adquirem aprendendo 'sobre', mas vivenciando experiências que afetem os sentimentos. Acredita-se que a concretização da democracia exige dos cidadãos tanto o conhecimento das causas e dos processos que determinam as injustiças pessoais e sociais, quanto o conhecimento das alternativas democráticas da sociedade para superá-las. Educar para os Direitos Humanos é, prioritariamente, criar uma cultura cujo embasamento seja o homem com dignidade, direitos e responsabilidades; é possibilitar a reflexão, desenvolver o espírito crítico e incitar o reconhecimento e a aceitação do 'diferente' nos outros. Para chegarmos a uma sociedade justa e democrática a que aspiramos, é essencial mudar as mentalidades. Acreditamos que isso só acontecerá pela educação e uma educação que incuta valores, ética, justiça, tolerância e fraternidade - fundamentos de uma nova ordem social" (GENEVOIS, Margarida Pedreira Bulhões. Educação $e \quad$ Direitos Humanos. Disponível em <www.dhnet.org.br/educar/textos/genevois_edh.pdf>. Acesso em 15/01/2014).

${ }^{251}$ PRUDENTE, Eunice Aparecida de Jesus. Educação em Direitos: Um Caminho para a Igualdade Racial. In Revista Brasileira de Filosofia, ano 60, n. 236, pp. 63-66, jan.-jun./2011.
} 
aceitação da adoção inter-racial. O respeito pelo outro e a valorização das diferenças, sejam elas raciais, sociais, econômicas, religiosas, de sexo ou culturais, possibilita a convivência harmônica entre todos os indivíduos e a construção de um conhecimento mais democrático.

O alcance desta educação integradora, que tem como consequência o respeito ao próximo e a diminuição da discriminação, entretanto, não se obtém apenas através de ações universais. O Poder Público deve se valer da adoção de $\underline{\text { accões afirmativas }}^{252}{ }^{2}$ voltadas para a educação, com a finalidade de alcançar a inclusão das crianças e jovens negros no ambiente escolar. $^{253}$

${ }^{252}$ O Relatório de Desenvolvimento Humano: Racismo, Pobreza e Violência, do Programa das Nações Unidas pelo desenvolvimento- PNUD atesta que: "Em face da violência contínua (da escravidão até os dias atuais) a que está submetida a população negra, uma única abordagem não será eficaz para criar oportunidades iguais. É imprescindível que o Estado lance mão de duas políticas públicas: Universais que são aplicadas sem distinção ou privilégio para o grupo beneficiário, e focalizadas, que têm como objetivo incluir os mais diversos grupos que compõem a sociedade brasileira. Entre essas últimas, estão as ações afirmativas. (...) As políticas de ação afirmativa justificam-se no Brasil porque as diferenças raciais persistem ao longo das décadas, seja em faces de crescimento, seja em faces de desaceleração da economia. Em vários casos, mesmo quando negros e brancos melhoram em algum indicador, os brancos melhoram mais e as desigualdades entre ambos persistem e aumentam".

${ }^{253}$ Muitos estudiosos são contra a política de cotas raciais, por entenderem que as políticas de cunho econômico solucionariam o problema da exclusão dos negros no país. Este raciocínio, que tem como base a íntima ligação entre pobreza e racismo (que é inegável) é fortemente combatido por Daniela Ikawa, nos seguintes termos: "O argumento da identidade entre o problema da discriminação racial e o problema da discriminação econômica apresenta duas falhas: (a) não descreve o problema de forma correta; e (b) aponta uma solução de cunho prescritivo, também incorreta. A ligação entre discriminação racial e pobreza não implica, contudo, que haja identidade entre esses dois fatores (Essa ligação e, na verdade, comum a grande parte dos grupos discriminados, como mulheres, indígenas, pessoas com deficiência, minorias étnicas). Nesse ponto, cabe tratar da segunda falha do argumento, a falha de cunho prescritivo: as ações afirmativas de cunho unicamente econômico podem não atingir a hierarquia racial. James Sterba, por exemplo, ao analisar o caso americano, indica que programas que levam em consideração fatores de classe como renda, educação dos pais, proporção de famílias que recebem seguro social o bairro, proporção de adultos sem segundo grau no bairro provocaram queda na seleção de negros em comparação com ações afirmativas de cunho racial. No mesmo sentido, aponta Richard Fallon que se a ação afirmativa de cunho econômico é considerada a melhor opção na substituição de ações afirmativas de cunho racial, é uma melhor opção muito inferior à primeira no que se refere à raça, já que o status do grupo racial discriminado perdurará dentro da política econômica. No mesmo sentido ainda, entendem Ronald Dworkin, William Bowen e Derek Bok que as ações afirmativas de cunho econômico alcançarão principalmente brancos pobres. Visto que apenas $2 \%$ dos matriculados brancos e $14 \$$ dos matriculados negros em universidades seletivas americanas em 1989 vêm de posições sócioeconômicas mais baixas, Bowen e Bok indicam que 'a substituição (do sistema racial) por um sistema baseado na classe econômica reduzira drasticamente a qualidade do grupo de negros e hispanos selecionáveis, seriamente impedindo a meta de preparar os líderes mais hábeis, membros da minoria, para a sociedade e para a vida profissional'. Supondo-se que no Brasil a realidade seria similar, não é possível a substituição da ação afirmativa de cunho racial por uma ação afirmativa de cunho econômico com os mesmos resultados. O que é possível, e provavelmente desejável, é a cumulação entre ações afirmativas de cunho racial e ações afirmativas de cunho econômico" (IKAWA, Daniela. Direito às Ações Afirmativas em Universidades Brasileiras. In SARMENTO, Daniel; IKAWA, Daniela; PIOVESAN, Flávia. Igualdade, Diferença e Direitos Humanos. Rio de Janeiro: Lumen Juris, 2010. pp. 394-397). 
Com a finalidade de implementar a educação em direitos humanos no país, o Programa Nacional de Direitos Humanos- PNDH-3, aprovado pelo Decreto Federal n. 7.037/2009, estabeleceu como um dos seus Eixos Orientadores a Educação e Cultura em Direitos Humanos (Eixo n. V), composto pelas seguintes diretrizes a saber: (1) Diretriz 18: efetivação das diretrizes e dos princípios da política nacional de educação em Direitos Humanos para fortalecer uma cultura de direitos; (2) Diretriz 19: fortalecimento dos princípios da democracia e dos Direitos Humanos nos sistemas de educação básica, nas instituições de ensino superior e nas instituições formadoras; (3) Diretriz 20: reconhecimento da educação não formal como espaço de defesa e promoção dos Direitos Humanos; (4) Diretriz 21: promoção da Educação em Direitos Humanos no serviço público; e (5) Diretriz 22: garantia do direito à comunicação democrática e ao acesso à informação para consolidação de uma cultura em Direitos Humanos.

Especificamente no que se refere às crianças, o Fundo das Nações Unidas para a Infância- UNICEF ${ }^{254}$ no relatório denominado "O impacto do racismo na infância"

${ }^{254}$ De acordo com as informações obtidas junto ao portal eletrônico do UNICEF Brasil, “O Fundo das Nações Unidas para a Infância - UNICEF está presente no Brasil desde 1950, liderando e apoiando algumas das mais importantes transformações na área da infância e da adolescência no País, como as grandes campanhas de imunização e aleitamento, a aprovação do artigo 227 da Constituição Federal e o Estatuto da Criança e do Adolescente, o movimento pelo acesso universal à educação, os programas de combate ao trabalho infantil, as ações por uma vida melhor para crianças e adolescentes no semi-árido brasileiro. $\mathrm{O}$ UNICEF está presente em praticamente todo o território nacional. O trabalho das equipes do UNICEF impacta diretamente e para melhor a vida das crianças, dos adolescentes e de suas famílias. Nos últimos cinco anos, o UNICEF, ao lado de seus muitos aliados, ajudou o Brasil a: (1) reduzir a mortalidade infantil em municípios do Semi-árido brasileiro em 14,4\%, entre 2003 e 2005 (quando a redução em média nacional foi de 6,2\%). Na mesma região, reduzir de 9,2\% para 6,2\% o número de crianças de até 2 anos de idade com desnutrição, aumentar em 10\% o número de crianças na pré-escola, criar 170 conselhos municipais de direitos da criança e do adolescente e mobilizar 1,8 milhão de crianças em torno de projetos de educação ambiental. Tudo isso a partir da mobilização do Selo UNICEF Município Aprovado, desenvolvido entre 2005 e 2006, e da qual participaram 1.179 municípios dos 11 Estados do Semi-árido, a região mais pobre e mais vulnerável do Brasil, onde vivem 13 milhões de meninas e meninos; (2) treinar mais de 22 mil agentes comunitários de saúde, educadores de creches e pré-escolas para assegurar sobrevivência, desenvolvimento, participação e proteção das crianças desde o período pré-natal até os 6 anos de idade, alcançando 2,4 milhões de famílias em 718 municípios de 14 Estados brasileiros; (3) reduzir de 24,8\%, em 1997, para 12,7\%, em 2006, o número de crianças de até 1 ano de idade sem registro civil de nascimento; (4) melhorar o aprendizado das crianças, principalmente as mais vulneráveis à repetência e à evasão escolar, como as indígenas, as quilombolas, as que trabalhavam na região do sisal, nos lixões e em outros bolsões de pobreza, garantindo a produção e disseminação de materiais paradidáticos para as crianças do Semi-árido e a inclusão das crianças com deficiências nas escolas; (5) melhorar a gestão democrática e os mecanismos de controle social em 3.292 municípios, além de contribuir com 1.618 municípios para que criassem e gerenciassem os Conselhos Escolares; (6) adquirir no mercado internacional, em parceria com o governo brasileiro, 110 mil testes rápidos de HIV para distribuir entre mulheres grávidas no Norte e Nordeste, a fim de prevenir a transmissão vertical (a infecção durante a gravidez, parto e aleitamento materno) do HIV/aids; (7) mapear 2,5 mil grupos organizados de adolescentes, envolvidos na melhoria das condições de vida de suas comunidades, na oferta de atividades de esporte, cultura, educação, na prevenção da violência e da gravidez na adolescência; (8) ajudar outros sete países (Bolívia, Cabo Verde, Guiné Bissau, Nicarágua, Paraguai, São Tomé e Príncipe, Timor Leste) a oferecer acesso universal à prevenção, cuidados e tratamento 
(2010), alertou sobre a necessidade: (1) de educar as crianças para o respeito à diferença;

(2) estimular o convívio de crianças de raça diversa; (3) denunciar as práticas de racismo;

(4) inserir nos currículos escolares a história dos povos indígenas e dos afrodescendentes, dentre outras.

Dessa maneira, não restam dúvidas de que já estão sendo adotadas medidas tendentes ao alcance da educação em direitos humanos, formal e informal, em especial com a finalidade de promover a inclusão social e o combate da discriminação.

Estas medidas possibilitarão, juntamente com as políticas públicas de valorização da família e com o amparo psicológico aos interessados em adoção, que a adoção interracial seja aceita não apenas pelos adotantes, como também pela sociedade.

do HIV/aids, com especial ênfase em crianças, adolescentes e mulheres grávidas; (9) elaborar a criação de 1.072 centros de referência especializados no atendimento de crianças vítimas de violência física e sexual; (10) publicar dados contundentes sobre como a iniqüidade racial e étnica no Brasil afeta sobremaneira as crianças e adolescentes" (disponível em http://www.unicef.org/brazil/pt/overview.html). 


\section{CAPÍTULO 5}

\section{A ADOÇÃO INTER-RACIAL COMO MECANISMO DE DESENVOLVIMENTO PESSOAL RECÍPROCO E DE INCLUSÃO SOCIAL}

\subsection{A realidade brasileira}

De acordo com as pesquisas realizadas pela Associação dos Magistrados Brasileiros, pelo Conselho Nacional de Justiça e pela psicóloga Lidia Natalia Dobrianskyj Weber, ${ }^{255}$ analisadas de forma detalhada no Capítulo anterior, a grande maioria dos interessados na adoção é branca e prefere adotar crianças brancas, apesar de a maioria das crianças disponíveis para adoção ser negra (no sentido lato).

Antes de se adentrar nas consequências práticas destes dados para o processo de desenvolvimento humano, de prevenção da violência e de inclusão social, é preciso perquirir os motivos históricos e sociais destas estatísticas. Por que a maior parte das crianças institucionalizadas no Brasil é negra?

A resposta para esta pergunta não é encontrada na análise, pura e simples, de nossa história recente. A exclusão dos negros tem origem no Brasil colônia, mais especificamente nas estruturas econômicas e jurídicas que permitiram a exploração, durante anos, da mão de obra escrava em benefício da metrópole portuguesa.

Conforme relatado por Robin Blackburn, ${ }^{256}$ os negros que vieram para o Brasil trabalhavam nas grandes plantações de cana-de-açúcar por mais de dezesseis horas por dia, em condições climáticas desfavoráveis e eram submetidos a açoitamentos constantes. ${ }^{257}$

\footnotetext{
${ }^{255}$ WEBER, Lidia Natalia Dobrianskyj. Aspectos Psicológicos das Famílias por Adoção. In LEITE, Eduardo de Oliveira (org.). Grandes Temas da Atualidade: Adoção. Aspectos Jurídicos e Metajurídicos. Rio de Janeiro: Forense, 2005. pp. 226/229.

${ }^{256}$ BLACKBURN, Robin. A Queda do Escravismo Colonial: 1776-1848. Rio de Janeiro: Record, 2002.

${ }^{257}$ Especificamente no que diz respeito às crianças escravas, Ana Maria Lima Lobo lembra que elas eram vítimas de castigos físicos intensos, que muitas vezes levavam à morte, de sevícias sexuais e de brutais brincadeiras dos filhos dos senhores brancos. A sociedade escravista era marcada pela violência (LOBO, Ana Maria Lima. Os Maus-Tratos na Infância e Adolescência. Aspectos Jurídicos. In PIOVESAN, Flávia; IKAWA, Daniela. Direitos Humanos: Fundamento, Proteção e Implementação. Perspectivas e Desafios Contemporâneos. Curitiba: Juruá, 2009. v. II, p. 879).
} 
Em razão do trabalho exaustivo, os escravos não tinham tempo de se preocupar com a própria saúde, muitos deles morrendo de doenças ou simples exaustão.

O Relatório de Desenvolvimento Humano brasileiro (2005) chamou a atenção para a violência física e emocional de que foram vítimas os cativos no período de escravidão, como mecanismo de punição e de coerção. Nesse sentido:

\begin{abstract}
A violência e a exploração intensa do trabalho cativo constituíram-se, portanto, em características inerentes ao escravismo, apenas sujeitas a princípios e regras que definiam quando e como determinado procedimento disciplinar e punitivo era "legítimo" ou não. Praticados quer pelo senhor, quer pelo feitor, atos de extrema brutalidade romperam variadas vezes o frágil equilíbrio construído sobre o uso da violência como pedagogia disciplinar. Nessas situações, a certeza da impunidade, derivada do poder despótico do senhor, resultou nos excessos disciplinares impostos aos cativos.

Os jesuítas, nos séculos 17 e 18, foram os primeiros a constatar não só a dependência do senhor em relação ao trabalho escravo como também a função da violência no controle dos cativos. Ao legitimar a escravidão, enfatizavam a idéia de reciprocidade que julgavam existir entre as obrigações de manter os escravos bem alimentados, saudáveis e adequadamente vestidos para o trabalho e os deveres que estes, enquanto trabalhadores, deveriam observar e cumprir. Admitiam que a quebra desse "acordo" deveria ser alvo de punição, e os castigos, sendo limitados, funcionariam como uma pedagogia, bem como um meio de conversão.

No entanto, mesmo com as pregações dos jesuítas em favor de limites nas punições, para muitos senhores qualquer desvio, insolência ou sinal de questionamento à idéia da "retribuição" pelos cativos resultava em brutal castigo. Embora os costumes restringissem excessos, as punições em geral ultrapassavam os limites socialmente aceitos: a indisciplina dos escravos, disfarçada ou agressiva, não raro desembocava em castigos atrozes, em geral aplicados no transgressor à vista dos demais. Era um quadro social no qual se tecia uma pedagogia da obediência, por meio da submissão e do medo intrínsecos aos códigos de controle social do escravismo. ${ }^{258}$ (grifos no original)
\end{abstract}

Ressalte-se, ademais, que a escravidão, para além da violência física, implicou em um processo de anulação da identidade dos negros capturados na África. Assim que chegavam ao Brasil, os escravos tinham seus nomes e suas crenças absolutamente ignorados pelos senhores dos engenhos, que faziam o possível para separar os negros da mesma etnia e para anular a sua identidade. Essas medidas visavam não apenas quebrar qualquer laço cultural e de afetividade que pudesse existir entre os escravos, como também evitar a formação de resistência à escravidão.

Esse processo de desconstrução da identidade dos negros africanos, porém, não obteve o êxito esperado pelos senhores de engenho. Tanto isso é verdade que os escravos

258 ONU. Programa das Nações Unidas para o Desenvolvimento. Relatório de Desenvolvimento Humano Brasileiro 2005. Brasília: PNUD, 2006. p. 26. 
procuravam resgatar a sua identidade cultural através da dança, dos cultos religiosos e da tradição. Nesse sentido:

Os cativos deparavam com um processo de recriação das identidades africanas logo após a captura na África e o traslado para as Américas. Suas tradições eram ignoradas, e eles ganhavam novas designações logo que desembarcavam no Brasil - a primeira a se tornar comum foi negros da Guiné, usada para quaisquer escravos, fossem ou não oriundos do Golfo da Guiné. As novas identidades eram acompanhadas também da prática de juntar escravos e escravas de etnias distintas, para evitar comunicação entre eles. Os nomes indicavam ora a procedência do porto de embarque ou da região genérica de onde eram provenientes; ora um grupo identificado no Brasil, com características semelhantes, aos olhos dos colonos; ou, ainda, a forma pela qual se autonomeavam.

(...)

Ressalte-se, nesse sentido, que a escravidão no Brasil, mesmo atropelando identidades tradicionais, não foi capaz de destruí-las completamente. Os próprios africanos podiam muito bem saber quem era quem a partir de sua inserção em determinados grupos culturais, identificando as experiências particulares de cada etnia. Os senhores não conseguiram apagar a memória das tradições e das culturas africanas nem minar os laços de solidariedade e identidade política que emergiam nos momentos de revolta e conflitos abertos na ordem escravista.

Um campo importante para preservar e reconstruir identidades foram as práticas religiosas tradicionais,contra as quais se insurgiu a Igreja Católica. Se, no plano da violência física, as repreensões da Igreja aos senhores eram mais severas, a situação se invertia em alguns planos da violência simbólica. Em meio à ContraReforma, que visava resgatar a pureza da fé católica atingida pela cisão da cristandade com a Reforma Protestante, as religiões e os rituais africanos sofreram feroz perseguição e rígidos controles por parte da Igreja Católica. Os calundus e as mandingas, demonizados pelo Santo Ofício, levaram alguns negros e negras aos cárceres inquisitoriais. ${ }^{259}$ (grifos no original)

Frise-se, entretanto, que a manutenção da identidade cultural dos escravos dentro dos engenhos de cana-de-açúcar e a posterior formação dos quilombos não foram responsáveis pela abolição da escravidão no Brasil, que ocorreu apenas em razão de pressões externas, aos 13 de maio de 1888 (com a publicação da Lei Áurea, pela Princesa Isabel). A fragilidade do movimento negro deveu-se, principalmente, à miscigenação e à hierarquia criada pelos senhores de engenho entre os próprios escravos. ${ }^{260}$

259 ONU. Programa das Nações Unidas para o Desenvolvimento. Relatório de Desenvolvimento Humano Brasileiro 2005. Brasília: PNUD, 2006, pp. 27-28.

${ }^{260}$ Vale mencionar que a miscigenação continua a ser um dos motivos da fragilidade do movimento negro nos dias atuais, conforme lembrado pelo Relatório de Desenvolvimento Humano brasileiro, elaborado em 2005: "Apesar do crescimento do ativismo negro e da amplitude de seu leque de atuação, ele ainda não conseguiu se tornar um movimento de massas no Brasil, país em que quase metade da população é preta ou parda. O movimento negro agrega poucos ativistas, que em sua maioria são de classe média ou em ascensão social. A produção bibliográfica não oferece explicações conclusivas sobre isso, mas uma das hipóteses é que esse segmento está exposto a um tipo de discriminação racial mais explícito do que aquele que atinge os mais pobres; a frustração daí decorrente teria facilitado o surgimento da consciência e do protesto racial por parte dessas pessoas. No entanto, esse recorte deve ser visto com reservas, já que o termo classe média oculta diferenças raciais marcantes - as condições de vida dos negros da classe média são relativamente precárias, o 
Diversamente do que se imaginava, a abolição da escravidão melhorou, de forma significativa, a qualidade de vida e a situação econômica da população negra no Brasil. Isto porque, "as economias são tão estruturalmente monopolizadas que a abolição do trabalho escravo não altera o modo de produção e em muitos casos só faz reforçar os monopólios". ${ }^{261}$ Dessa maneira, os negros libertos passaram a trabalhar como assalariados, ganhando (quando muito) apenas o suficiente para a sua subsistência.

Com o início do processo de industrialização, a situação econômica dos libertos e de seus descendentes apenas piorou. Por não possuírem estudo e qualificação, os negros não conseguiram se inserir no mercado de trabalho, formando um contingente de mão de obra ociosa e miserável nas vizinhanças das cidades.

De lá para cá, em razão da inexistência de políticas públicas efetivas de inserção social, a situação econômica e social dos negros no Brasil pouco mudou. Com a apropriação de diferenças raciais pelo processo de colonização, a pobreza e a discriminação são, ainda hoje, fatos indissociáveis. Como bem lembrado por Daniel Sarmento: ${ }^{262}$

(...) para lutar contra a discriminação racial e as desigualdades, é preciso reaprender a olhar. Olhar para ver que são quase sempre negras as crianças famélicas que fazem malabarismos com bolinhas nos sinais de trânsito das grandes cidades; são quase sempre negras as famílias que dormem sob as marquises, na imundice das sarjetas das nossas ruas; quase sempre negras são as

que se reflete na reduzida capacidade desses cidadãos de mobilizar recursos em prol do movimento. Outro aspecto que tem dificultado a mobilização da comunidade negra é o apelo social e cultural à miscigenação. Não por acaso, ao longo das décadas os censos mostram uma persistente queda da parcela da população que se autoclassifica como preta e um aumento contínuo da população que se autoclassifica como parda. Apesar de serem em geral desprezíveis as diferenças entre os indicadores sociais desses dois grupos, a miscigenação é vista como uma estratégia de superação do racismo por meio do apagamento dos traços africanos na descendência. As vantagens simbólicas da miscigenação se alimentam, no imaginário coletivo, da idéia de que o branco é a tradução do que é bom e desejável, e o negro sinônimo do que é negativo e humilhante. A visão de que a miscigenação funciona como uma solução para a superação do racismo no Brasil despolitiza o problema. Além disso, as distinções sociais de fenótipo no interior do grupo considerado negro seguirão agindo como redutores do potencial de solidariedade entre as vítimas da discriminação racial, criando um obstáculo à construção de um movimento de massas" (ONU. Programa das Nações Unidas para o Desenvolvimento. Relatório de Desenvolvimento Humano Brasileiro 2005. Brasília: PNUD, 2006.pp. 110111).

${ }^{261}$ SALOMÃO FILHO, Calixto; FERRÃO, Brisa Lopes de Mello; RIBEIRO, Ivan César. Concentração, Estruturas e Desigualdade: As origens coloniais da pobreza e da má distribuição de renda. São Paulo: Idcid, 2006. p. 40.

${ }^{262}$ SARMENTO, Daniel. Direito Constitucional e Igualdade Étnico-Racial. In PIOVESAN, Flávia; SOUZA, Douglas Martins de. Ordem Jurídica e Igualdade Étnico-Racial. Rio de Janeiro: Lumen Juris, 2008. p. 61. 
vítimas da violência policial e da tortura. Olhar para ver que a miséria no Brasil tem cor. (grifo nosso)

Este breve apanhado histórico demonstra que a pobreza no Brasil não está associada simplesmente à carência de recursos financeiros. Muito pelo contrário, a pobreza vai além da desigualdade econômica, para alcançar a falta de representatividade dos interesses da camada mais vulnerável da população e, consequentemente, a inexistência de políticas públicas eficazes para a solução do problema. Em outras palavras, a pobreza abrange a desigualdade econômica, social, racial e política. ${ }^{263}$

Especificamente no caso da população negra, que representa mais da metade dos brasileiros (caso se considere uma classificação racial menos restrita, capaz de abranger negros e pardos), ${ }^{264}$ a inexistência de poder e de representação política foi gerada pelo processo de escravidão, que ademais de desconsiderar os direitos- civis, sociais e políticos- dos cativos, estabeleceu uma hierarquia entre os escravos, dificultando a sua organização e a consequente exigência de condições dignas de vida.

Esta ausência de representatividade e de reconhecimento fez com que se estabelecesse no país um ciclo vicioso, por meio do qual as vítimas do descaso e da violência se tornam os agentes do descaso e da violência, não apenas contra terceiros como também contra a própria família.

Neste contexto, é comum que pais que não tiveram afeto, educação de valores e oportunidades de crescimento emocional e profissional descontem em seus filhos as suas frustrações, através de comportamentos negativos, ou simplesmente reproduzam os padrões a que foram submetidos na infância.

\footnotetext{
263 Nesse sentido, conferir: ONU. Programa das Nações Unidas para o Desenvolvimento. Relatório de Desenvolvimento Humano Brasileiro 2005. Brasília: PNUD, 2006. p. 45.

264 “A desproporção entre negros e brancos no Brasil levou a critérios de classificação racial fenotípica que promoveram indivíduos mestiços à categoria de 'brancos'. Uma classificação genotípica teria gerado problemas políticos incontornáveis, pelo fato de existirem membros não-brancos entre as elites do império. Enquanto isso, nos Estados Unidos a população negra sempre foi minoritária. Naquele país, a definição política da classificação racial foi genotípica e por hipodescendência, ou seja, os frutos da miscigenação eram considerados negros em razão de ser esta a 'raça' considerada 'inferior'. A graduação de cor, embora existente no interior do segmento negro norte-americano, não teve a mesma validação externa, impedindo assim que as fragmentações internas se tornassem obstáculos à mobilização política unificada das mulheres e dos homens negros" (ONU. Programa das Nações Unidas para o Desenvolvimento. Relatório de Desenvolvimento Humano Brasileiro 2005. Brasília: PNUD, 2006. pp. 45-46).
} 
De acordo com o Relatório de Desenvolvimento Humano, elaborado no Brasil em 2009/2010, a família é um dos principais agentes da violência contra crianças e adolescentes:

\begin{abstract}
(...) Segundo dados disponíveis no Sistema de Informação para a Infância e Adolescência (Sipia), desde 1999, foram registrados 1.003.833 fatos de violência de direitos de crianças e adolescentes. E os pais são apontados como principais agentes de violação. A violência doméstica contra crianças e adolescentes pode ser classificada em distintas formas: violência física, violência sexual, violência psicológica, negligência e violência fatal. Dentre essas, a negligência aparece como a forma de violência mais notificada, o que aponta para o fato da possível existência de uma cultura camuflada do abandono infantil no país.

A violência física aparece fortemente associada aos castigos corporais infligidos às crianças, que podem variar de uma "palmada" a espancamentos e homicídios. Essa aparece muitas vezes associada com a violência psicológica, que pode deixar profundas marcas no desenvolvimento emocional das crianças. As consequências da violência sofrida dentro de casa se alastram para outras esferas das vidas das crianças e adolescentes e trazem impactos para a dinâmica da violência na comunidade. Adolescentes que sofrem maus-tratos familiares sofrem mais episódios de violência na escola, vivenciam mais agressões na comunidade e transgridem mais as normas sociais, fechando assim um círculo de violência. ${ }^{265}$
\end{abstract}

Com a finalidade de evitar que estes atos de violência tragam consequências irreversíveis ao desenvolvimento das crianças e adolescentes vitimados, o sistema jurídico prevê a destituição do poder familiar dos responsáveis. Esta destituição, por sua vez, implica (na grande maioria das vezes) na institucionalização destas crianças e adolescentes.

Sendo assim, pode-se afirmar que, em última análise, a institucionalização de crianças negras no Brasil está relacionada, principalmente (ainda que não exclusivamente), com a escassez de recursos financeiros, a ausência de planejamento familiar, a falta de oportunidades, a discriminação racial e a violência decorrente da exclusão social.

Nesse sentido, merece destaque a lição de Elizabeth Bartholet: ${ }^{266}$

265 ONU. Programa das Nações Unidas para o Desenvolvimento. Relatório de Desenvolvimento Humano Brasileiro. Brasília: PNUD, 2009/2010. p. 169.

266 "There is no denying the strong connection between socioeconomic status and child maltreatment. For political reasons many have found it important at various point in history to minimize this connection, but today it is widely acknowledged. This does not mean, obviously, that all poor people are destined to abuse or neglect their children. Most do not. And it is of course true that child abuse and neglect occur among all racial groups and on all economic levels. But statistics confirm what the psychological literature and our own experience and common sense suggest: to an overwhelming degree the people who treat their children badly are people who have been treated badly by their own parents nad by the larger society. They are people who fall disproportionately into groups that are at the bottom of the socioeconomic ladder. Children from families earning less than \$15,000 per year are most than twenty-two times more likely to suffer maltreatment involving demonstrable harm than children from families earning more than $\$ 30,000$, and they are more than forty-four times more likely to be neglect. More than 90 percent of child maltreatment occurs 
Não há como negar a forte ligação entre o status socioeconômico e o maltrato infantil. Por motivos políticos, muitas pessoas entenderam, em diversas épocas da história, que seria melhor negar esta conexão, mas hoje esta situação é amplamente reconhecida. Isto não significa, por óbvio, que todas as pessoas pobres estão destinadas a abusar e negligenciar seus filhos. A maioria não o faz. É verdade que o abuso e o maltrato infantis ocorrem em todos os grupos raciais e níveis econômicos. Mas as estatísticas confirmam o que a literatura psicológica e a nossa própria experiência e senso comum sugerem: na grande maioria as pessoas que tratam mal seus filhos são as mesmas que foram maltratadas por seus pais e pela sociedade. São pessoas que integram as camadas mais baixas da sociedade. Crianças provenientes de famílias que ganham menos de 15.000 mil dólares no ano são vinte e duas vezes mais propensas a sofrer maus tratos que as crianças de família que ganham mais de 30.000 dólares por ano, e elas são quarenta e quatro vezes mais propensas a serem vítimas de negligência. Mais de $90 \%$ do abuso infantil ocorre em famílias com renda abaixo da média e os índices mais altos de maus-tratos estão concentrados na população mais pobre da classe pobre. As crianças de famílias pobres, e minorias raciais que são desproporcionalmente pobres, são mais prováveis de serem removidas de suas famílias para instituições e abrigos. O percentual de crianças afro-americanas em abrigos, em qualquer época, é cinco vezes maior que o percentual da população em geral.

Muitos dizem que esta situação decorre da discriminação imposta pelo sistema de assistência social infantil. Eles alegam que estamos removendo crianças de suas famílias com base exclusivamente na situação econômica de seus pais. Não há dúvidas de as crianças são, ocasionalmente, removidas de suas famílias porque seus pais não têm condições de prover suas necessidades ou porque eles perderam suas casas. Mas estes casos são exceções à regra de que os pais não podem ser acusados de violação das leis de abuso e negligência somente por não possuírem condições financeiras ou serem vítimas de injustiça social. As crianças não são normalmente removidas com fundamento em denúncias de pequenas negligências. (...) É a pobreza em conjunto com outros fatores que ocasionam o maltrato infantil.

Percebe-se, dessa maneira, que a pobreza e a exclusão social levam à institucionalização crescente de crianças e adolescentes, que, ao atingirem a maioridade e deixarem os abrigos, não terão qualquer suporte material, psicológico e emocional ${ }^{267}$ para a

in families with incomes below the median, and the highest maltreatment rates are concentrated in the poorest of the poor families. Children from poor families, and from racial minorities groups who are of course disproportionately poor, are much more likely to be removed from their families to foster and institutional care. The percentage of African-American children in foster care at any one time is roughly five times their percentage in the general population. Many say this is simply demonstrative of 'discrimination' by the child welfare system. They say that we are removing children from parents solely on the basis of the parents' economic situation. It's no doubt true that children are occasionally removed simply because a parent cannot afford any form of child care, or because a parent loses her home. But these are exceptions to the general rule today, which holds that so long as the parent is guilty of nothing more than poverty, or homelessness, or their victimization by societal injustice, that will not be found in violation of the abuse and neglect laws. Children are not typically removed on the basis of minor forms of abuse and neglect. (...) It is poverty together with other factors that results in child maltreatment" (BARTHOLET, Elizabeth. Nobody's Children. Abuse and Neglect, Foster Drift and the Adoption Alternative. Boston: Beacon Press, 1999. pp. 233-234).

${ }^{267}$ Lidia Natalia Dobrianskyj Weber lembra a resistência da doutrina à institucionalização e de seus efeitos no desenvolvimento das crianças e adolescentes a ela submetidas: Como bem coloca Pilotti (1995, p. 41) "... a institucionalização acarreta mais danos que benefícios para a maioria das crianças internas devido ao predomínio das seguintes características negativas no desenvolvimento do ser humano: impossibilidade de interação com o mundo exterior e conseqüente limitação da convivência social; invariabilidade do ambiente 
vida social e, muito provavelmente, viverão à margem do sistema, em situação de pobreza extrema ou de miséria. Estas carência e ausência de reconhecimento, por sua vez, levarão os filhos destes indivíduos à institucionalização, formando-se um ciclo vicioso.

Em outras palavras, a institucionalização prolongada de crianças e adolescentes no Brasil dá causa a um ciclo, no qual os que são abandonados hoje serão os que irão abandonar amanhã.

Neste contexto, a inserção familiar dessas crianças, através da adoção inter-racial (em virtude da realidade brasileira) surge como solução para a quebra do ciclo acima descrito, propiciando o desenvolvimento recíproco do adotante e do adotado e, em última análise, a inclusão social e a prevenção da violência.

\subsection{A adoção inter-racial como mecanismo de desenvolvimento humano} recíproco

Antes de se adentrar na análise da contribuição da adoção inter-racial para o desenvolvimento dos envolvidos diretos em seu processo (adotante e adotado), é preciso conceituar a expressão “desenvolvimento".

Até bem pouco tempo, o conceito de desenvolvimento estava relacionado exclusivamente a aspectos econômicos. Esta visão individualista do instituto, entretanto, sofreu alterações nos últimos anos, assim como ocorreu com outros conceitos da Tradição Jurídica Ocidental. $^{268}$

\footnotetext{
físico, do grupo de parceiros e das autoridades; planejamento das atividades externas à criança, com ênfase na rotina e na ordem; vigilância contínua; ênfase na submissão, silêncio e falta de autonomia. As conseqüências negativas deste processo - tanto para o indivíduo como para a sociedade - surgem dos graves e irreversíveis efeitos exercidos pela institucionalização sobre os afetados". Com efeito, a criança interna desenvolve uma auto-estima extremamente baixa, caracterizada por uma imagem negativa de si mesma o que interfere no desenvolvimento normal das relações interpessoais. A inserção social destas crianças fica extremamente limitada". (WEBER, Lidia Natalia Dobrianskyj. Quero que alguém me chame de filho: abandono, pobreza, institucionalização e o direito à convivência familiar. Disponível em $<$ http//lidiaw.sites.uol.com.br/convivenciafamiliar.htm>. Acesso em 12.01.2013) (grifo nosso).

${ }^{268}$ Neste sentido, conferir BERMAN, Harold J. Direito e Revolução. A Formação da Tradição Jurídica Ocidental. São Leopoldo: Unisinos, 2006. p. 47.
} 
Em 1986, ${ }^{269}$ a Organização das Nações Unidas, por meio da Declaração sobre o Direito ao Desenvolvimento (artigo $1^{\circ}, 1$ ), reconheceu ser o desenvolvimento um direito fundamental, dotado de aspectos econômicos, sociais, culturais e políticos, voltado ao bem-estar de todos os indivíduos, nos seguintes termos:

O direito ao desenvolvimento é um direito humano inalienável em virtude do qual toda pessoa humana e todos os povos estão habilitados a participar do desenvolvimento econômico, social cultural e político, a ele contribuir e dele desfrutar, no qual todos os direitos humanos e liberdades fundamentais possam ser plenamente realizados.

A leitura deste documento internacional deixa claro que o desenvolvimento é um processo complexo, que se destina à plena realização dos direitos humanos, não se limitando ao alcance de uma economia satisfatória.

Nesta mesma linha de raciocínio, o Programa Nacional para o Desenvolvimento, das Nações Unidas, deixa claro que o desenvolvimento tem como principal destinatário o ser humano, justificando-se a utilização da expressão desenvolvimento humano. Nesse sentido:

\begin{abstract}
O conceito de desenvolvimento humano nasceu definido como um processo de ampliação das escolhas das pessoas para que elas tenham capacidades e oportunidades para serem aquilo que desejam ser.

Diferentemente da perspectiva do crescimento econômico, que vê o bem-estar de uma sociedade apenas pelos recursos ou pela renda que ela pode gerar, a abordagem de desenvolvimento humano procura olhar diretamente para as pessoas, suas oportunidades e capacidades. A renda é importante, mas como um dos meios do desenvolvimento e não como seu fim. É uma mudança de perspectiva: com o desenvolvimento humano, o foco é transferido do crescimento econômico, ou da renda, para o ser humano.

O conceito de Desenvolvimento Humano também parte do pressuposto de que para aferir o avanço na qualidade de vida de uma população é preciso ir além do viés puramente econômico e considerar outras características sociais, culturais e políticas que influenciam a qualidade da vida humana. Esse conceito é a base do Índice de Desenvolvimento Humano (IDH) e do Relatório de Desenvolvimento Humano (RDH), publicados anualmente pelo PNUD. ${ }^{270}$
\end{abstract}

\footnotetext{
${ }^{269}$ No mesmo ano, coincidentemente, a ONU proclamou a Declaração sobre Princípios Sociais e Jurídicos Relativos à Proteção e ao Bem-Estar das Crianças, com Particular Referência à Colocação em Lares de Guarda, nos Planos Nacional e Internacional. Referido documento deixa claro que teve origem na preocupação "com o grande número de crianças que ficam abandonadas ou órfãs por causa da violência, dos distúrbios internos, dos conflitos armados, dos desastres naturais, das crises econômicas ou dos problemas sociais". Ademais, asseverou que "em todos os procedimentos de adoção e colocação em lares de guarda, os interesses das crianças devem ser primeiramente considerados" (www.camara.gov.br).

${ }^{270}$ Disponível em <http://www.pnud.org.br/IDH/DesenvolvimentoHumano.aspx?indiceAccordion=0\&li=li_DH>. Acesso em 20/01/2014.
} 
Com a finalidade de averiguar o status do desenvolvimento humano dos diversos países integrantes das Nações Unidas, Mahbubul Haq e o economista indiano Amartya Sen, ganhador do Prêmio Nobel de Economia de 1998, criaram, em 1990, o Índice de Desenvolvimento Humano (IDH).

Os três elementos centrais do Índice de Desenvolvimento Humano (saúde, educação e renda) são mensurados, atualmente, da seguinte forma: (1) uma vida longa e saudável (saúde) é medida pela expectativa de vida; (2) o acesso ao conhecimento (educação) é medido pela: i) média de anos de educação de adultos (assim considerados a partir dos 25 anos); e ii) expectativa de anos de escolaridade para crianças na idade de iniciar a vida escolar e (3) o padrão de vida (renda) é medido pela Renda Nacional Bruta (RNB) per capita, expressa em poder de paridade de compra (PPP) constante, em dólar. ${ }^{271}$

Percebe-se, assim, que a educação desempenha papel fundamental no alcance do desenvolvimento de um país, devendo ser entendida não apenas em seu aspecto formal, como também informal, conforme já visto no capítulo anterior. Nesse sentido, vale mencionar as conclusões do Relatório de Desenvolvimento Humano, elaborado no Brasil, em 2009/2010:

\begin{abstract}
Dentro da perspectiva do desenvolvimento humano, a educação é a maneira pela qual um indivíduo adquire não somente conhecimentos, mas habilidades para a vida, contribuindo para a autonomia das pessoas, sua participação na sociedade, suas escolhas, sua formação crítica e ética. Nesse sentido a educação não é apenas instrumental, preparando para o mercado de trabalho, mas também importante em si mesma, ajudando as pessoas a tomarem decisões sobre o que realmente importa em suas vidas. Em outras palavras, podemos dizer que a educação não pode ser reduzida a ensino. Chamamos, assim, de uma "educação de valor" aquela educação que tanto prepara para o mercado de trabalho quanto para a vida, englobando aqui o desenvolvimento da capacidade psicológica e moral dos indivíduos de desenvolverem valores importantes para eles e a sociedade onde vivem. ${ }^{272}$
\end{abstract}

Com a finalidade de alcançar a espécie de desenvolvimento proposta acima, os Estados-membros integrantes da Organização das Nações Unidas, em setembro de 2000, na Cúpula do Milênio, assumiram o compromisso de cumprir uma agenda global para a

${ }^{271}$ Disponível em <http://www.pnud.org.br/IDH/IDH.aspx?indiceAccordion=0\&li=li_IDH>. Acesso em 20/01/2014.

${ }^{272}$ ONU. Programa das Nações Unidas para o Desenvolvimento. Relatório de Desenvolvimento Humano Brasileiro 2009/2010. Brasília: PNUD, 2010. p. 150. 
promoção da paz, dos direitos humanos e do desenvolvimento, por meio da adoção de oito Objetivos de Desenvolvimento do Milênio (ODM), a saber:

1. Erradicar a pobreza e a fome;

2. Atingir o ensino básico fundamental;

3. Promover a igualdade entre os sexos e a autonomia das mulheres;

4. Reduzir a mortalidade infantil;

5. Melhorar a saúde materna;

6. Combater o HIV/AIDs, a malária e outras doenças;

7. Garantir a sustentabilidade ambiental e

8. Estabelecer uma parceria mundial para o desenvolvimento.

Nos anos que se seguiram, diversas reuniões e resoluções foram realizadas pela ONU, com o objetivo de se alcançar o desenvolvimento dos diversos países dela integrantes, por meio da adoção de políticas de redução da pobreza, da fome e de doenças opressivas, além de medidas destinadas à proteção do meio-ambiente (Conferência de Monterrey, Resolução da ONU 58/291 e Cúpula Mundial de 2005). ${ }^{273}$

Compartilhando o ideal do compromisso internacional acima relatado, Amartya Sen lembra que os países precisam enxergar muito além do crescimento econômico, direcionando a sua atenção para o alcance da garantia da liberdade e da melhora de vida dos indivíduos. ${ }^{274}$

Nesta linha de raciocínio, o crescimento econômico, sem qualquer preocupação com a garantia das liberdades individuais, aqui entendidas, em sentido amplo, como a proteção dos direitos fundamentais, não possui nenhum fundamento. Este entendimento, aliás, foi endossado por Celso Lafer, ${ }^{275}$ em intervenção apresentada no Painel sobre “ $O$

\footnotetext{
${ }^{273}$ Para mais esclarecimentos, conferir GOMES, Maria Tereza Uille. Direitos Humanos, Desenvolvimento e os Objetivos de Desenvolvimento do Milênio (ODM). In FOLMANN, Melissa; ANNONI, Daniela. Direitos Humanos: Os 60 Anos da Declaração Universal da ONU. Curitiba: Juruá Editora, 2008. pp. 267-268.

${ }^{274}$ SEN, Amartya. Desenvolvimento como Liberdade. São Paulo: Companhia das Letras: 2000, p. 29: “(...) O desenvolvimento deve estar relacionado, sobretudo, com a melhora da vida que levamos e das liberdades que desfrutamos. Expandir as liberdades que temos razão de valorizar não só torna nossa vida mais rica e mais desimpedida, mas também permite que sejamos seres sociais mais completos, pondo em prática nossas volições, interagindo com o mundo que vivemos e influenciando este mundo".

${ }^{275}$ Nesse sentido, verificar LAFER, Celso. Liberdade e Igualdade: Reflexões sobre o crescimento econômico e a democracia. In $123-141$. . Ensaios sobre a liberdade. São Paulo: Perspectiva, 1980. Parte III, item 5, pp.
} 
Problema da Distribuição de Renda no Brasil e no Desenvolvimento”, em 1977, anos antes da promulgação, pela Organização das Nações Unidas, da Declaração sobre o Direito ao Desenvolvimento (1986).

Dessa maneira, a visão de que a desigualdade social pode ser solucionada por meio, exclusivamente, do aumento da produção, defendida por J.K Galbraith, ${ }^{276}$ é insuficiente, por levar em consideração apenas um aspecto do problema, a saber: o econômico.

Sendo assim, o desenvolvimento só pode ser alcançado por meio de ações conjuntas nas áreas política, econômica, social e cultural, privilegiando-se, sempre, a proteção dos direitos humanos. Afinal, como bem lembrado por Josiane Rose Petry Veronese, ${ }^{277}$ na "sociedade, que valoriza unicamente o sentido material da existência, (...) tudo se torna descartável, os vínculos afetivos, os sentimentos, as condutas e até mesmo as instituições (....)".

Com base no raciocínio desenvolvido até então, pode-se afirmar que a proteção da família é essencial para a garantia dos demais direitos fundamentais dos indivíduos e, consequentemente, para o desenvolvimento de seus membros e da sociedade.

Isto porque, é no seio da família que se inicia o processo de socialização das crianças, através da relação de amor e de carinho estabelecida entre elas e seus pais ou responsáveis. A formação dos vínculos de afetividade entre os membros da família é responsável pelo desenvolvimento saudável do indivíduo e pela qualidade das relações sociais que ele estabelecerá com o mundo exterior. ${ }^{278}$

${ }^{276}$ GALBRAITH, J.K. The Affluent Society. Fortieth Anniversary Edition. Boston: Mariner Books, 1998, pp. 79-80: o autor defende que as discussões a respeito da desigualdade perderam parte de sua importância com o aumento da produtividade. O aumento da produção é visto como política de distribuição de renda e de igualdade social.

${ }^{277}$ VERONESE, Josiane Rose Petry. Discriminação e atentados ao exercício da cidadania da criança e do adolescente. In PEREIRA, Tânia da Silva (coord). O Melhor Interesse da Criança: Um Debate Interdisciplinar. Rio de Janeiro: Renovar, 1999. p. 659.

${ }^{278}$ Até os dois anos a criança passa por um estágio chamado sensório-motor, e os sentimentos são de caráter intuitivo e intraindividuais, ligados às percepções das experiências imediatas, como alegria, prazer, dor, tristeza, ou ligados às ações primárias, como aprender a caminhar, que pode gerar contentamento ou desapontamento, sucesso ou fracasso. Com base nas experiências, a criança começa a sentir confiança, simpatia ou desgosto com relação aos objetos ou às pessoas. Já a partir dos 2 e até os 7 anos criança aprende, reorganiza e interioriza cognitivamente as ações vividas e alguns comportamentos normativos ditados pelos pais, como por exemplo, a obediência; paralelamente ao surgimento da linguagem, ocorre uma progressiva estruturação afetiva e os sentimentos tornam-se mais estáveis e duráveis, dando lugar aos sentimentos morais, associados ao relacionamento com as outras pessoas, como afeto, simpatia, antipatia, certo grau de 
Diversos estudos ${ }^{279}$ demonstram a importância do amor e do afeto dos pais para o desenvolvimento da personalidade dos filhos e para a manutenção das relações sociais. Uma vez desenvolvida a personalidade individual, com base em sólidas relações de amor e de confiança, o ser humano terá condições de interagir, por meio de um discurso não violento. ${ }^{280}$ Esta situação, por óbvio, colaborará para a proteção dos direitos humanos- aí abrangidos a igualdade e a segurança-e, consequentemente, para o desenvolvimento.

Ademais do estabelecimento de relações afetivas, conforme já visto no capítulo anterior, os pais são responsáveis pela educação informal de seus filhos, caracterizada pela transmissão de valores positivos ${ }^{\mathbf{2 8 1}}$ (como a generosidade, a honestidade, a tolerância, o

reciprocidade, respeito de forma unilateral ou à figura de autoridade e obediência. Nessa fase a criança é ainda centrada em si mesma e tem dificuldade em se colocar no lugar do outro. A partir dos 7 e até os 11 anos, as crianças começam a ser mais autônomas, sendo capazes de realizar operações concretas e de fazer suas próprias avaliações morais. As crianças identificam o que é desejável normativamente, desenvolvendo e interiorizando valores de respeito mútuo, de responsabilidade, reciprocidade, honestidade, honradez, justiça e de cooperação com os outros por vontade própria e não por imposição externa. Dessa forma, origina-se uma organização de valores de forma autônoma na medida em que a criança estrutura um conhecimento complexo com respeito: i) às normas morais; ii) à relação com suas ações; e iii) aos impactos sobre os outros e sobre si mesmo. Já na fase dos 12 até os 15 anos de idade, os adolescentes experimentam o último estágio do desenvolvimento intelectual, com maior capacidade de reflexão, de formulação de hipóteses e resolução de problemas. Inicia-se a definição da identidade com possíveis conflitos e surgimento de valores idealistas. Em geral, a evolução dentro desses estágios de desenvolvimento e formação de valores dependerá em parte das características particulares de cada indivíduo e do grau de estímulos e interações com o ambiente e com as pessoas, que se dá inicialmente na família (ONU. Programa das Nações Unidas para o Desenvolvimento. Relatório de Desenvolvimento Humano Brasileiro 2009/2010. Brasília: PNUD, 2010.pp. 105-106).

${ }^{279}$ A respeito da importância do amor para o desenvolvimento do ser humano, conferir HONNETH, Axel. A Luta por Reconhecimento. A gramática moral dos conflitos sociais. São Paulo: Editora 34, 2009, p. 177: “(...) aquela camada fundamental de uma segurança emotiva não apenas na experiência, mas também na manifestação das próprias carências e sentimentos, propiciada pela experiência intersubjetiva do amor, constitui o pressuposto psíquico do desenvolvimento de todas as outras atitudes de autorrespeito". (grifo nosso). Conferir, também, WINNICOTT, Donald W. A família e o desenvolvimento individual. Trad. de Marcelo Brandão Cipola. São Paulo: Martins Fontes, 1983.

280 Sobre a relação entre a violência e linguagem, consultar RICOEUR, Paul. Violência e Linguagem. Leituras 1: Em torno ao Político. São Paulo: Edições Loyola, 1995. p. 59-68.

${ }^{281}$ De acordo com o RDH Brasil, "A discussão sobre valores pode parecer moralista, subjetiva e anacrônica. Frequentemente, o discurso sobre valores é usado para condenar os outros, para reprimir, para julgar. Em sociedade, cada indivíduo tem direito à sua voz, à sua opinião. Sempre que confrontados, sentimos que ninguém tem o direito de nos impor suas próprias preferências ou julgamentos morais. Então, por que devemos nos importar com os valores, que podem servir mais para agravar do que para resolver os problemas? Primeiro, porque parece que no Brasil a violência urbana e a degradação dos valores de vida invadiram todas as áreas. Essa ausência de valores de vida, isto é, de valores vivos, postos em prática, pode ser percebida no trabalho, no trânsito, na escola, nos esportes, nos serviços de saúde, na política, em casa, entre outros espaços. Nesse sentido, tratar os valores é uma maneira de entendermos o enfraquecimento dos vínculos interpessoais, o esvaziamento do sentido das ações coletivas, a banalização da violência, a violação dos direitos humanos, a proliferação do preconceito e o desengajamento moral que marca muito da vida cotidiana no país. Segundo, porque pensar a questão dos valores nos abre novas perspectivas para encararmos velhos problemas, como a desigualdade, as instituições políticas e as regras de sociabilidade que caracterizam não somente a história do nosso país, mas de toda a América Latina. Terceiro, porque a discussão sobre valores nos permite entender melhor as relações interpessoais em nível micro, como nas famílias, entre amigos, em pequenos grupos, abrindo a possibilidade de pensarmos estratégias de promoção de 
respeito, dentre outros), através do diálogo transparente e respeitoso e, principalmente, dos exemplos diários. Nesse sentido:

\begin{abstract}
No processo de formação de valores, a família desempenha um papel muito importante, uma vez que representa o primeiro ambiente de socialização que a criança conhece e em meio do qual os pais ou as pessoas que cumprem a função parental são responsáveis por estimular, transmitir, ensinar e reforçar os valores que devem orientar a vida e o comportamento das crianças. Posteriormente, serão os pais que influenciarão os valores adotados na passagem da criança à fase adolescente e adulta, de forma que ela se insira na sociedade e se desenvolva como pessoa plena e autônoma.

(...)

Compreender a dinâmica e os determinantes da formação de valores dentro das famílias é de vital importância para ampliar o entendimento do desenvolvimento humano, uma vez que este pode ser promovido ou restringido dependendo de como se dê esse processo de construção e transmissão de valores nos filhos, que impacta nos modos de comportamento e interações sociais e, portanto, no bemestar das pessoas. Condições que facilitem esse processo de construção de valores dentro da família aumentam a propensão a comportamentos desejáveis e propiciam uma convivência harmônica.

Em contraste, se um ambiente inadequado - caracterizado pela ausência dos pais ou pela agressividade física e moral entre os cônjuges ou com os filhospredomina, a transmissão e construção de valores pode ser inconsistente, podendo prejudicar o desenvolvimento do indivíduo e de seus relacionamentos. Dinâmicas internas da família, como as práticas utilizadas pelos pais para educar seus filhos, podem influenciá-los tanto a comportamentos pró-sociais, relacionados à empatia, à solidariedade e à gratidão, quanto a comportamentos anti-sociais, como a mentira, a evasão escolar e o uso de drogas. Nesse sentido, consideramos a família como uma unidade de formação social que pode potencialmente moldar a estrutura de valores que uma pessoa possui, podendo também influenciar a propensão para certas atitudes e comportamentos e afetar positivamente ou negativamente seu desenvolvimento humano. ${ }^{282}$.
\end{abstract}

Percebe-se, assim, a importância da proteção da família- sob suas diversas formas-, como núcleo essencial da sociedade e ambiente propício ao desenvolvimento de seus integrantes. Isto porque, é na família que "os indivíduos (...) trocam experiências afetivas, aprendem a lidar com os afetos, e com isso, se constituem enquanto seres humanos e se desenvolvem com vista à vida em sociedade". ${ }^{283}$

compromissos sociais duradouros, de laços de solidariedade, quebrando a tendência de afastamento e descompromisso que existe com os próximos. Podemos, assim, ver a exclusão moral e a desumanização do outro como forma de violência que nos impede buscar o desenvolvimento humano com autonomia ética dos indivíduos. Finalmente, cabe mencionar que pensar os valores nos possibilita tratar do desenvolvimento humano construído a partir do diálogo e da democracia, em que valores são vistos como resultados de práticas sociais e experiências subjetivas compartilhadas, concretizando em ações e instituições que simbolizam e mediam diferentes interesses políticos e sociais" (ONU. Programa das Nações Unidas para o Desenvolvimento. Relatório de Desenvolvimento Humano Brasileiro 2009/2010. Brasília: PNUD, 2010. pp. 85-86).

${ }^{282}$ ONU. Programa das Nações Unidas para o Desenvolvimento. Relatório de Desenvolvimento Humano Brasileiro 2009/2010. Brasília: PNUD, 2010. pp. 100-101.

${ }^{283}$ SANTOS, Romualdo Baptista dos. A Tutela Jurídica da Afetividade. Curitiba: Juruá, 2011. p. 153. 
Neste contexto, a adoção inter-racial surge como importante mecanismo de desenvolvimento humano, não apenas do adotado, que até então estava privado da convivência familiar adequada, como também do adotante.

Apesar das críticas feitas à adoção inter-racial, com fundamento no melhor interesse (1) da criança, (2) do adotante e (3) da sociedade, restou demonstrado neste trabalho que esta medida não causa nenhum prejuízo aos envolvidos. Muito pelo contrário, a adoção inter-racial possibilita a superação do preconceito e da discriminação, através do convívio entre pessoas de raças diversas.

Sendo assim, a formação de famílias multirraciais viabiliza não apenas o respeito ao ser humano, em suas igualdades e diferenças, como também a troca de experiências a respeito de culturas diversas e a quebra de preconceitos arraigados, há anos, na sociedade e na consciência dos indivíduos. Trata-se de valiosa oportunidade de revisão de opiniões e crenças sobre a família e humanidade.

Sobre este aspecto, mostra-se extremamente relevante a contribuição da professora Elizabeth Bartholet:

No contexto de uma sociedade lutando contra a diferença racial, os estudos sobre
adoção inter-racial são extremamente interessantes. Eles não demonstram apenas
que as crianças negras se adaptam bem às famílias brancas. Eles não demonstram
simplesmente que nós colocamos os interesses das criaças em risco quando
optamos por aguardar a disponibilidade de uma família negra. Os estudos
mostram que crianças negras criadas por famílias brancas se sentem confortáveis
com a sua raça e igualmente confortáveis ao se relacionarem com brancos.
Ademais, os estudos comprovam que a adoção inter-racial tem um impacto
interessante nas atitudes raciais dos membros brancos destas famílias. Os pais
tendem a descrever que suas vidas foram modificadas de forma significativa e
enriquecidas em razão da experiência de se tornar uma família inter-racial. Eles
mencionam que adquiriram uma nova percepção das questões raciais. As
crianças brancas destas famílias são vistas como tão comprometidas quanto seus
pais com relação aos seus irmãos ou irmãs negros. As crianças brancas e negras
destas famílias são descritas como não possuidoras de preconceito racial e
possuidoras de uma visão de mundo pluralista e multicultural, na qual a
humanidade de uma pessoa é mais relevante que a sua raça.
Os estudos mostram pais e crianças, irmãos e irmãs, se relacionando nestas
famílias transraciais como se a raça não representasse uma barreira ao amor e ao
comprometimento. Eles demonstram as crianças negras e brancas crescendo com
o senso de que a raça não deveria ser uma barreira em seu relacionamento com
as pessoas. Em uma sociedade marcada por conflitos raciais, estes estudos
mostram seres humanos transcendendo as diferenças raciais. ${ }^{284}$

284 "In the context of a society struggling with the issue of how to deal with racial difference, the studies of transracial adoptive families are extraordinarily interesting. They do not simply show that black children do 
Frise-se que muitos pesquisadores norte-americanos, contrários à adoção interracial, sustentam que a tolerância racial advinda da concessão da medida é extremamente prejudicial aos interesses da comunidade negra, por representar um enfraquecimento de seus ideais. Esta visão, entretanto, se coaduna com uma postura separatista da sociedade, que não é (e nem deve ser) compatível com a realidade brasileira.

Como bem lembrado por Elizabeth Bartholet, o respeito às diferenças raciais e a convivência harmoniosa de pessoas de raças diversas é vista de forma positiva ou negativa, a depender da perspectiva política de cada um. Tanto isso é verdade que, para aqueles que acreditam que o mundo se subdivide um uma comunidade negra e em outra branca, o respeito entre pessoas destas duas raças é um sinal negativo, ao passo que para aqueles que acreditam que existe apenas uma comunidade, formada por seres humanos, o respeito à diversidade e a integração social são um avanço. Nesse sentido:

Mas a conclusão de que esta evidência é positiva ou negativa em suas
implicações para a adoção transracial depende inteiramente da perspectiva
política de cada um. A partir da perspectiva daqueles que acreditam que brancos
e negros devem aprender a viver, de forma compatível, no mesmo mundo, com
respeito e consideração mútua, apreciando as diferenças raciais e culturais, bem
como a humanidade que lhes é comum, a evidência é positiva. E não há qualquer
evidência de que as diferenças em atitudes raciais tenham qualquer influência
negativa no bem-estar das crianças adotadas de forma transracial.
A evidência demonstra, de forma clara, que os adotados desenvolvem um forte
senso de identidade negra, diversamente do que muitos alegam. (...) Algumas das
evidências demonstram, inclusive, que a adoção transracial produz um impacto
positivo na sensação de conforto que as crianças possuem quanto à sua
identidade racial.
(...)
A principal diferença obtida pelas evidências é que as crianças negras criadas por
brancos são mais abertas que os negros criados dentro da mesma raça a respeito
de relacionamentos com brancos, mais confortáveis nestes relacionamentos e
mais interessadas em uma convivência inter-racial. Ademais, há evidência de

well in white adoptive homes. They do not simply show that we put black children at risk by delaying or denying placement while we await black homes. The studies shows that black children raised in white homes are comfortable with their blackness and also uniquely comfortable in dealing with whites. In addition, the studies show that transracial adoption has as interesting impact on the racial attitudes of the white members of these families. The parents tend to describe their lives as significantly changed and enriched by the experience of becoming an interracial family. They describe themselves as having developed a new awareness of racial issues. The white children in transracial adoptive families are described as committed to and protective of their black brothers and sisters. The white as well as the black children are described as exhibiting an unusual absence of white racial bias, and as unusually committed to the vision of pluralistic, multicolored world in which a person's humanity is more important than his race. The studies show parents and children, brothers and sisters, relating to each other in these transracial families as if race was no barrier to love and commitment. They show the back adopted and the white birth children growing up with the sense that race should not be a barrier in their relationships with people in the larger social context. In a society torn by racial conflicts, these studies show human beings transcending racial difference". (BARTHOLET, Elizabeth. Where do Black children belong? The politics of race matching in adoption. University of Pennsylvania Law Review, n. 05, vol. 139, p. 1225-26, may 1991). 
estes adotados pensam que a raça não é o fator mais importante para a sua definição ou para a definição de seus amigos. Estudos demonstraram que alguns adotados de forma transracial se vêem como birraciais ou americanos ou humanos, ao invés de negros. ${ }^{285}$

Dessa maneira, a adoção inter-racial possibilita não somente o desenvolvimento dos adotados, por preservar-lhes a integridade física, emocional, psicológica e espiritual (em razão da colocação destas crianças em lares estruturados, evitando a institucionalização prolongada), mas também o desenvolvimento dos adotantes e das pessoas a ele ligadas.

Tanto isso é verdade que esta medida permite que as pessoas, diretamente ligadas ao processo de adoção inter-racial ou por ele afetadas (1) vejam a família como uma instituição vinculada ao afeto e não a aspectos meramente biológicos; (2) respeitem-se em virtude de características e valores que vão muito além da raça; (3) valorizem as suas diferenças; (4) conheçam uma cultura diferente da sua e (5) tenham a oportunidade de compreender o preconceito e modificar a visão das pessoas com quem convivem a respeito de raça.

Ressalte-se que a integração racial viabilizada por meio da adoção entre pessoas de raças diversas, ademais de alterar os valores dos adotantes e dos adotados, acaba modificando os valores da própria sociedade brasileira. Com o tempo, a tendência é de que os valores negativos, especificamente no que se refere à raça, cedam lugar ao respeito e às atitudes pacíficas.

\footnotetext{
285 "But conclusions that this evidence is positive or negative in its implications for transracial adoption depend entirely on one's political perspective. From the perspective of one who believes that blacks and whites should be learning to live compatibly in one world, with respect and concern for each other, with appreciation for their racial and cultural differences as well as their common humanity, the evidence is positively heartwarming. And there is no evidence that the differences in racial attitudes have any negative bearing on the welfare of the transracial adoptees themselves. The evidence shows clearly that transracial adoptees develop a strong sense of black identity, contrary to many of the claims made about the evidence. (...) Indeed, some of the evidence indicates that transracial adoption may even have a positive impact in terms of black children's sense of comfort with their racial identity. (...) The main difference revealed by the evidence is that transracial adoptees appear more positive than blacks raised inracially about relationships with whites, more comfortable in those relationships, and more interested in a racially integrated lifestyle. There is also evidence that they think race is not the most important factor in defining who they are or who their friends should be. Studies have found some transracial adoptees describing themselves as biracial or American or 'human', rather than black (...)". (BARTHOLET, Elizabeth. Where do Black children belong? The politics of race matching in adoption. University of Pennsylvania Law Review, n. 05, vol. 139, p. 12161218, may 1991).
} 
Por este raciocínio, resta claro que a adoção produz reflexos individuais e sociais, estabelecendo-se uma relação de complementaridade recíproca entre os campos privado e público. $^{286}$

Em suma, a proteção da família, mais especificamente da família formada em razão da adoção inter-racial, viabiliza o desenvolvimento dos seres humanos envolvidos e, consequentemente, da sociedade e do país.

\subsection{A adoção inter-racial como medida preventiva da violência e da exclusão} social

Antes de se adentrar na defesa da convivência familiar como mecanismo de prevenção da violência e de inclusão social, é preciso esclarecer o que se entende por violência.

De acordo com a Organização Mundial da Saúde (OMS), a violência se caracteriza como o

Uso intencional da força física ou do poder, real ou em ameaça, contra si próprio, contra outra pessoa, ou contra um grupo ou uma comunidade, que resulte ou tenha grande possibilidade de resultar em lesão, morte, dano psicológico, deficiência de desenvolvimento ou privação. ${ }^{287}$

A definição de violência dada pela Organização Mundial da Saúde, assim como a maior parte dos conceitos de violência formulados por pesquisadores das áreas jurídica e das ciências sociais, envolve a intencionalidade do ato violento, capaz de causar dano físico ou psicológico ao próprio agressor ou a terceiro.

Deve-se lembrar, porém, que a violência gerada pela força física não é a única modalidade de violência presente em nossa sociedade. O Relatório de Desenvolvimento

\footnotetext{
${ }^{286}$ De acordo com o Relatório de Desenvolvimento Humano, "Como podemos separar o mundo 'privado' do mundo 'público', quando o que acontece nas famílias molda tanto a sociedade na qual vivemos quanto a agenda nacional de prioridades? Uma abordagem que focaliza os valores resgata a importância de uma visão sistêmica para a solução de problemas complexos, destacando não somente a sua integração, mas a simplicidade das ações que os compõe" (ONU. Programa das Nações Unidas para o Desenvolvimento. Relatório de Desenvolvimento Humano Brasileiro 2009/2010. Brasília: PNUD, 2010. p. 211).

${ }^{287}$ Organização Mundial de Saúde (OMS). Relatório mundial sobre a violência e saúde. s.l. 2002.
} 
Humano (Brasil, 2005) chama a atenção para a violência simbólica, caracterizada pelo desrespeito dos valores compartilhados pela sociedade ou, até mesmo, pela reprodução de valores negativos pela mesma sociedade, em detrimento de uma determinada camada da população. Exemplo desta modalidade de violência é o preconceito racial. Nesse sentido:

(...) A associação da violência com a força física é a representação mais corriqueira do fenômeno. Tanto na etimologia como no seu uso cotidiano, a palavra "violência" está presente preponderantemente associada à aplicação de força física. No entanto, a relação do conceito com a dimensão moral e valorativa do fenômeno nem sempre é tão evidente. E essa relação é fundamental para analisarmos a relação entre violência e valores de vida.

Sempre que uma violência é cometida, vem acompanhada de uma agressão moral. Ou seja, não é possível analisar uma manifestação de violência ou mesmo definir esse conceito sem considerar a dimensão moral implicada nas agressões. Em outras palavras, não basta, por exemplo, considerar o uso da força física, mas é importante examinar o significado atribuído pelas pessoas àquela aplicação da força. Esta pode ser interpretada como um fenômeno corriqueiro. Ou como um grave desrespeito e, consequentemente, violência. Ou seja, a dimensão das crenças e significados é essencial para a compreensão de como se dá a classificação de um ato como violento (pp. 162-163).

No século XIX, por influência da Europa e dos Estados Unidos, alguns estudiosos brasileiros defenderam a tese do racismo científico, fundado "em pesquisas da biologia e da antropologia física, que criaram a idéia de raça com base em investigações sobre as diferenças físicas e visíveis entre grupos humanos e civilizações”.

Estas teorias, porém, não conseguiram fincar raízes definitivas no Brasil, em razão da miscigenação racial de nosso povo e do receio de se colocar em risco a integridade nacional. Como bem lembrado pelo Relatório de Desenvolvimento Humano:

Deve-se ressalvar, no entanto, que algumas características da sociedade brasileira (miscigenação, diversidade cultural e ausência de práticas extremadas e intolerantes de racismos) constituíram-se em parte como uma blindagem à incorporação plena e original dos postulados do racismo científico. Se desde o período da escravidão foi produzido no Brasil um discurso racista que veiculou estereótipos e signos depreciadores sobre os brasileiros de origem africana, esse mesmo discurso não logrou constituir um racismo legalizado, expresso em códigos formais e em espaços institucionalizados distintos, como ocorreu nos Estados Unidos e na África do Sul.

Outras razões podem explicar o fracasso parcial do racismo científico em criar uma codificação bipolar entre brancos e negros na sociedade brasileira. Por exemplo, os fatores geográficos que apontavam uma inquestionável maioria de indivíduos de origem africana nas regiões norte e nordeste e uma presença mais significativa de brancos, embora miscigenados, no sul e no centro-sul. Uma segregação formal poderia ser arriscada para a integração do país.

Face a essa realidade demográfica e territorial, o projeto de nação das elites dominantes buscou lograr uma segregação silenciosa dos brasileiros de origem africana, não positivada no direito, mas excluindo-os e marginalizando-os 
através de mecanismos informais de natureza social, econômica e cultural - ao mesmo tempo em que implantava as políticas imigrantistas como instrumento de branqueamento do país. Esse projeto de nação sonhava, para um futuro não muito distante, com a completa absorção demográfica dos negros pela miscigenação, enquanto no presente a discriminação e a desqualificação social atuariam no sentido de reduzir seu acesso a direitos e oportunidades. ${ }^{288}$

Dessa maneira, a discriminação racial no país não se fundou em teorias científicas, nem tampouco foi codificada. A discriminação foi velada e se manifestou, durante anos, através de práticas de exclusão social e política, ancoradas na crença da democracia racial.

A partir da década de 60 , entretanto, o preconceito racial passou a ser enfrentado de forma mais direta pelos Estados, em razão da formação de movimentos sociais pela defesa dos direitos civis dos negros e das mulheres. De lá para cá muitas medidas foram adotadas, na esfera nacional e internacional, para prevenir e combater toda e qualquer forma de discriminação racial, bem como promover a inclusão social das camadas mais vulneráveis da sociedade.

Exemplo marcante desta mudança de postura é a Convenção Internacional sobre a Eliminação de Todas as Formas de Discriminação Racial, ratificada pelo Brasil em 1969. De acordo com o artigo $1^{\circ}$ desta Convenção,

\begin{abstract}
Artigo $1^{\circ}$ - Para os fins da presente Convenção, a expressão "discriminação racial" significará toda distinção, exclusão, restrição ou preferência baseada em raça, cor, descendência ou origem nacional ou étnica que tenha por objeto ou resultado anular ou restringir o reconhecimento, gozo ou exercício em um mesmo plano (em igualdade de condição) de direitos humanos e liberdades fundamentais nos campos político, econômico, social, cultural ou em qualquer outro campo da vida pública.

2. Esta Convenção não se aplicará às distinções, exclusões, restrições e preferências feitas por um Estado-parte entre cidadãos e não cidadãos.

3. Nada nesta Convenção poderá ser interpretado como afetando as disposições legais dos Estados-partes, relativas à nacionalidade, cidadania e naturalização, desde que tais disposições não discriminem contra qualquer nacionalidade particular.

4. Não serão consideradas discriminação racial as medidas especiais tomadas com o único objetivo de assegurar o progresso adequado de certos grupos raciais ou étnicos ou de indivíduos que necessitem da proteção que possa ser necessária para proporcionar a tais grupos ou indivíduos igual gozo ou exercício de direitos humanos e liberdades fundamentais, contanto que tais medidas não conduzam, em consequência, à manutenção de direitos separados para diferentes grupos raciais e não prossigam após terem sido alcançados os seus objetivos.
\end{abstract}

${ }^{288}$ ONU. Programa das Nações Unidas para o Desenvolvimento. Relatório de Desenvolvimento Humano Brasileiro 2005. Brasília: PNUD, 2006. pp. 31-34. 
Conforme se percebe pela leitura deste artigo da Convenção, a comunidade internacional decidiu que a discriminação racial deve ser combatida por meio da adoção de políticas universais e especiais, nestas últimas incluídas as chamadas ações afirmativas. Optou-se pela complementaridade destes dois regimes, por se concluir que a adoção isolada de apenas um deles seria insuficiente para solucionar este problema que atinge a grande maioria das sociedades contemporâneas.

Nesta linha, a Constituição Federal de 1988, além de prever o princípio da igualdade (e da proibição da discriminação de qualquer espécie), tipificou o racismo como crime inafiançável.

Feitas estas considerações preliminares, é possível afirmar que a violência no Brasil é causada tanto por atos de agressão física, como de agressão moral, e tem como causas, ainda que não únicas, a exclusão econômica e social e a descrença no sistema jurídico, indicando que toda e qualquer medida tendente a diminuí-la deve considerar políticas de inclusão. Nesse sentido, vale transcrever a lição de Oscar Vilhena Vieira: ${ }^{289}$

\begin{abstract}
As exclusões econômicas e sociais, oriundas de níveis extremos e persistentes de desigualdade, causam a invisibilidade daqueles submetidos à pobreza extrema, a demonização daqueles que desafiam o sistema e a imunidade dos privilegiados, minando a imparcialidade da lei. (...) Porém, se a invisibilidade pode ser aceita em sociedades tradicionais, ela se torna um problema muito preocupante num regime democrático e num contexto consumista. Para muitos que não experimentaram a sensação de serem tratados com igual consideração e respeito por aqueles responsáveis por aplicar a lei e pela sociedade em geral, não existe razão alguma para que ajam em conformidade com o Direito. Em outras palavras, para aqueles criados como invisíveis em sociedades não tradicionais, há ainda menos razões morais ou instrumentais para respeitar as leis. A consequiência é que, ao desafiar a invisibilidade através de meios violentos, os indivíduos começam a ser vistos como uma classe perigosa, a qual nenhuma proteção legal deve ser dada.
\end{abstract}

Assim como a discriminação deve ser combatida por políticas universais (de vedação do racismo) e especiais (de inclusão), a violência só pode ser solucionada através da adoção conjunta de políticas repressivas e preventivas. Não é isso, entretanto, que se vê no país.

\footnotetext{
${ }^{289}$ VIEIRA, Oscar Vilhena. A Desigualdade e a Subversão do Estado de Direito. In SARMENTO, Daniel et al (coord). Igualdade, Diferença e Direitos Humanos. Rio de Janeiro: Lumen Juris, 2010. pp. 207-208.
} 
Tanto isso é verdade que as discussões sobre a solução do problema da violência urbana $^{290}$ no Brasil continuam centradas na diminuição da maioridade penal e na instituição da pena de morte, em clara demonstração de que os brasileiros valorizam as medidas repressivas e ignoram (ou preferem ignorar) as causas diretas da violência. Entretanto, caso a solução puramente repressiva fosse efetiva, o encarceramento dos condenados implicaria na diminuição da violência. Não é isso, porém, o que vem ocorrendo na sociedade brasileira.

Apesar de os presídios do país apresentarem lotação máxima (não se adentrando aqui nas condições em que os presos vivem, já que a discussão se distancia do objeto desta pesquisa), a segurança não está aumentando e a pobreza não está diminuindo, deixando claro que a adoção de medidas meramente repressivas, sem qualquer preocupação com as políticas de reconhecimento e de inclusão social, é insuficiente (para não dizer inútil).

Neste contexto, a garantia da família, como entidade responsável pela formação da personalidade de seus membros e pela transmissão de valores, surge como alternativa à prevenção da violência no país.

Isto porque, ao transmitirem valores positivos aos seus filhos, através de uma conduta dialógica $^{291}$ e solidária, os pais são capazes de formar indivíduos seguros,

\footnotetext{
${ }^{290}$ Nas palavras de Sergio Adorno: “A tese que sustentava relações de causalidade entre pobreza, delinquiência e violência está hoje bastante contestada em inúmeros estudos (...). No entanto não há como deixar de reconhecer relações entre a persistência, na sociedade brasileira, da concentração da riqueza, da concentração de precária qualidade de vida coletiva nos chamados bairros periféricos das grandes cidades e a explosão da violência fatal. Mapas da violência, realizados para algumas capitais brasileiras na década passada, indicavam que as taxas de homicídios eram sempre e flagrantemente mais elevadas nessas áreas do que nos bairros que compõem o cinturão urbano melhor atendido por infraestrutura urbana, por oferta de postos de trabalho, por serviços de lazer e cultura. Recente estudo sugeriu que, no Município de São Paulo, a maior concentração de homicídios estava associada ao congestionamento habitacional, fenômeno característico dos bairros onde habitam preferencialmente trabalhadores urbanos de baixa renda (Cardia e Schiffer, 2000). Tudo isso parece indicar, nesses bairros, maior predisposição para desfechos fatais em conflitos sociais, interpessoais e intersubjetivos (...)". (ADORNO, Sergio. Exclusão socioeconômica e violência urbana. Porto Alegre, Sociologias, ano 4, no 8, pp.84-135, jul./dez. 2002).

${ }^{291}$ De acordo com o Relatório de Desenvolvimento Humano, "O diálogo ou comunicação positiva consiste na troca de explicações pacientes e no esclarecimento de dúvidas e de expressões de sentimentos e pensamentos, que incentivam um clima de confiança no qual os filhos se sentem à vontade para conversar sobre diferentes temas, inclusive sobre assuntos muito pessoais. Por meio do diálogo, é possível a aproximação, a intimidade e um relacionamento familiar de qualidade, além de ser importante na redução de comportamentos inapropriados entre jovens. O diálogo é importante em todas as etapas de crescimento dos filhos, porém, na adolescência se faz muito mais necessário, pois podem surgir possíveis conflitos entre as concepções dos pais e a dos jovens, o que gera tensões. Questões como a iniciação precoce da vida sexual, o uso de substâncias psicoativas e outros comportamentos considerados de risco fazem parte desse universo. A interação entre pais e crianças, o envolvimento dos pais nas atividades dos filhos, conselhos nos momentos
} 
autoconfiantes, que respeitam os direitos de terceiros, as diferenças naturais e culturais dos seres humanos e desprezam comportamentos violentos.

Dessa maneira, as crianças que crescem em lares estruturados recebem uma educação formal e informal voltada à valorização dos seres humanos (aí compreendida a valorização da vida, da integridade física, da diferença, da liberdade e de todos os demais direitos fundamentais dos indivíduos), possuindo poucas chances de praticar atos violentos (sejam eles físicos ou psicológicos).

Por outro lado, as crianças que são privadas do convívio familiar ou que são criadas por pais agressivos, negligentes ou simplesmente desinteressados em seu bem-estar físico, emocional e espiritual são propensas a comportamentos violentos, por repetirem padrões ou não valorizarem a vida própria e alheia.

Nesta linha de raciocínio, a violência surge como reação (ou consequência) da ausência de reconhecimento, em qualquer de suas esferas, a saber: reconhecimento na esfera do amor, ${ }^{292}$ reconhecimento na esfera do direito ${ }^{293}$ e reconhecimento na esfera da estima social. $^{294}$

difíceis, assim como práticas de apoio e incentivos facilitam a construção da autoestima" (ONU. Programa das Nações Unidas para o Desenvolvimento. Relatório de Desenvolvimento Humano Brasileiro 2009/2010. Brasília: PNUD, 2010. p. 213).

${ }^{292}$ De acordo com Axel Honneth, “(...) a criatividade infantil, e mesmo a faculdade humana de imaginação em geral, está ligada ao pressuposto de uma 'capacidade de estar só', que por sua vez se realiza somente através da confiança elementar na disposição da pessoa amada para a dedicação. (...) Se a mãe soube passar pelo teste de seu filho, tolerando os ataques agressivos sem privá-lo do amor, então da perspectiva dele, ela pertence de agora em diante a um mundo exterior aceito com dor; pela primeira vez, como foi dito, ele terá de tomar consciência agora de sua dependência em relação à dedicação dela. Se o amor da mãe é duradouro e confiável, a criança é capaz de desenvolver ao mesmo tempo, à sombra de sua confiabilidade intersubjetiva, uma confiança na satisfação social de suas próprias demandas ditadas pela carência; pelas vias psíquicas abertas dessa forma, vai se desdobrando nela, de maneira gradual, uma 'capacidade elementar de estar só'. (...) a criança pequena, por se tornar segura do amor materno, alcança uma confiança em si mesma que lhe possibilita estar a sós despreocupadamente" (HONNETH, Axel. A Luta por Reconhecimento. A gramática moral dos conflitos sociais. São Paulo: Editora 34, 2009. pp. 172-174).

293 “(...) para poder agir como uma pessoa moralmente imputável, o indivíduo não precisa somente de proteção jurídica contra interferências em sua esfera de liberdade, mas também da possibilidade juridicamente assegurada de participação no processo público de formação da vontade, da qual ele faz uso, porém, somente quando lhe compete ao mesmo tempo um certo nível de vida. Por isso, nos últimos séculos, em unidade com os enriquecimentos que experimenta o status jurídico do cidadão individual, foi-se ampliando também o conjunto de todas as capacidades que caracterizam o ser humano constitutivamente como pessoa: nesse meio tempo acrescentou-se às propriedades que colocam um sujeito em condições de agir autonomamente com discernimento racional uma medida mínima de formação cultural e de segurança econômica. (...) assim como no amor a criança adquire confiança para manifestar espontaneamente as suas carências mediante a experiência contínua da dedicação materna, o sujeito adulto obtém a possibilidade de conceber sua ação como uma manifestação da própria autonomia, respeitada por todos os outros, mediante a experiência do reconhecimento jurídico. Que o autorrespeito é para a relação jurídica o que a autoconfiaça 
Não restam dúvidas de que a falta de reconhecimento pelo amor, que se adquire na primeira infância, no relacionamento com os pais e, posteriormente, no relacionamento com os amigos e demais familiares, produz consequências nas demais esferas de reconhecimento acima mencionadas, por servir como base ou pressuposto psíquico do desenvolvimento de todas as outras atitudes de auto-respeito.

Em outras palavras, a criança que não recebe afeto no seio da família, em razão da ausência de confiança em si própria, tem sérias dificuldades de estabelecer relações sociais e, em última análise, de reivindicar direitos, sendo levada a ver na violência a única resposta para a ausência de reconhecimento sofrida. ${ }^{295}$

Sobre o tema da ausência de reconhecimento e de suas conseqüências para o indivíduo, merecem menção os ensinamentos de Axel Honneth:

Os maus-tratos físicos de um sujeito representam um tipo de desrespeito que fere
duradouramente a confiança, aprendida através do amor, na capacidade de
coordenação autônoma do próprio corpo; daí a consequência ser também, com
efeito, uma perda de confiança em si e no mundo, que se estende até as camadas

era para a relação amorosa é o eu já se sugere pela logicidade com que os direitos se deixam conceber como signos anonimizados de um respeito social, da mesma maneira que o amor pode ser concebido como a expressão afetiva de uma dedicação, ainda que mantida à distância: enquanto esse cria em todo ser humano o fundamento psíquico para poder confiar nos próprios impulsos carenciais, aqueles fazem surgir nele a consciência de poder se respeitar a si próprio, porque ele merece o respeito de todos os outros" (HONNETH, Axel. A Luta por Reconhecimento. A gramática moral dos conflitos sociais. São Paulo: Editora 34, 2009. pp. 192-195).

294 “Como tínhamos visto, diferentemente do reconhecimento jurídico em sua forma moderna, a estima social se aplica às propriedades particulares que caracterizam os seres humanos em suas diferenças pessoais: por isso, enquanto o direito moderno representa um medium de reconhecimento que expressa propriedades universais de sujeitos humanos de maneira diferenciadora, aquela segunda forma de reconhecimento requer um medium social que deve expressar as diferenças de propriedades entre sujeitos humanos de maneira universal, isto é intersubjetivamente vinculante. (...) A autocompreensão cultural de uma sociedade predetermina os critérios pelos quais se orienta a estima social das pessoas, já que suas capacidades e realizações são julgadas intersubjetivamente, conforme a medida em que cooperam na implementação de valores culturalmente definidos; nesse sentido, essa forma de reconhecimento recíproco está ligada também à pressuposição de um contexto de vida social cujos membros constituem uma comunidade de valores mediante a orientação por concepções de objetivos comuns" (HONNETH, Axel.A Luta por Reconhecimento. A gramática moral dos conflitos sociais. São Paulo: Editora 34, 2009. pp. 199-200).

295 De acordo com os ensinamentos de Márcia Lopes de Carvalho e Natalia Soares Franco, a ausência de cuidado dos pais com os filhos é uma das causas preponderantes da criminalidade. Nesse sentido: "Estudos sobre as causas da criminalidade e da violência dizem que as condutas da criança/adolescente infrator estão intimamente ligadas ao abandono e às seguintes situações familiares: a) desorganização ou inexistência de um grupo familiar; b) condições impróprias ou inadequadas da personalidade dos pais; c) renda familiar modesta, insuficiente ou mesmo vil; d) desemprego, subemprego com rentabilidade deficiente; e) falta de instrução ou qualificação profissional dos membros da família; f) moradia ou habitação inadequada e condições precaríssimas, inclusive de higiene, facilitando a proliferação do vício. Observamos em todas estas causas a ausência de cuidado" (CARVALHO, Márcia Lopes de; FRANCO, Natalia Soares. O cuidado na adoção: algumas experiências. In PEREIRA, Tânia da Silva; OLIVEIRA, Guilherme de (coords.). O cuidado como valor jurídico. Rio de Janeiro: Forense, 2008. p. 190). 
corporais do relacionamento prático com outros sujeitos, emparelhada com uma espécie de vergonha social.

(...)

Por isso, a particularidade nas formas de desrespeito, como as existentes na privação de direitos ou na exclusão social, não representa somente a limitação violenta da autonomia pessoal, mas também sua associação com o sentimento de não possuir o status de um parceiro da interação com igual valor, moralmente em pé de igualdade; para o indivíduo, a denegação de pretensões jurídicas socialmente vigentes significa ser lesado na expectativa intersubjetiva de ser reconhecido como sujeito capaz de formar juízo moral; nesse sentido, de maneira típica, vai de par com a experiência da privação de direitos uma perda de autorrespeito, ou seja, uma perda da capacidade de se referir a si mesmo como parceiro em pé de igualdade na interação com todos os próximos. Portanto o que aqui é subtraído da pessoa pelo desrespeito em termos de reconhecimento é o respeito cognitivo de uma imputabilidade moral, que, por seu turno, tem de ser adquirida a custo em processos de interação socializadora.

(...)

Por fim, em face desse segundo tipo de desrespeito, que lesa uma pessoa nas possibilidades de seu autorrespeito, constitui-se ainda um último tipo de rebaixamento, referindo-se negativamente ao valor social de indivíduos ou grupos (...). A degradação valorativa de determinados padrões de autorrealização tem para seus portadores a conseqüência de eles não poderem se referir à condução de sua vida como a algo a que caberia um significado positivo no interior de uma coletividade; por isso, para o indivíduo, vai de par com a experiência de uma tal desvalorização social, de maneira típica, uma perda de autoestima pessoal, ou seja, uma perda de possibilidade de se entender a si próprio como um ser estimado por suas propriedades e capacidades características. $^{296}$

Dessa maneira, a falta de reconhecimento nas esferas do amor, do direito e da estima social gera um ciclo vicioso, caracterizado pela carência de respeito próprio gerando situações de violência e situações de violência gerando carência de respeito próprio.

Neste contexto, propõe-se que a solução do problema da violência seja obtida através da inserção de crianças em ambiente familiar adequado, possibilitando a constituição de sujeitos de direito. Deixa-se de lado a ética da potência (caracterizada por posturas violentas) e adota-se a ética do diálogo (marcada por posturas pacíficas).

Esta abordagem, apesar de absolutamente lógica, é pouco utilizada nos debates públicos a respeito da violência, provavelmente em razão da natureza imediatista das políticas públicas brasileiras (que são criadas mais se pensando em votos do que na garantia da paz social). Seja qual for a causa desta lacuna, ainda há tempo para mudanças.

\footnotetext{
296 HONNETH, Axel. A Luta por Reconhecimento. A gramática moral dos conflitos sociais. São Paulo:
} Editora 34, 2009. pp. 215-218. 
Neste cenário de violência, causada pela falta de reconhecimento, a adoção interracial (aqui vista como a forma mais genuína do reconhecimento pelo amor, capaz de propiciar bases sólidas para o reconhecimento jurídico e para o reconhecimento pela solidariedade) de crianças abandonadas e institucionalizadas surge como instrumento de inclusão social, propiciando solução preventiva para grande parte dos problemas relacionados à violência no Brasil. 


\section{CONCLUSÃO}

Conforme se pode perceber pela leitura deste trabalho, o abandono e a institucionalização de crianças no país são um dos grandes problemas a serem enfrentados pelo Estado, pela sociedade e pela família.

As causas do abandono são diversas, mas não restam dúvidas de que a ausência de perspectivas e de amparo afetivo pode ser apontada como uma das principais fontes da institucionalização de crianças no Brasil.

A análise das causas do abandono é essencial para busca de alternativas para a institucionalização e para a quebra do ciclo vicioso formado entre os envolvidos.

Os Capítulos acima demonstram que os adultos que são vítimas de descaso, de violência e de negligência familiar têm a tendência de repetir este comportamento com seus filhos. Este dado comprova, claramente, que o afeto e o respeito são essenciais para a formação da personalidade dos indivíduos e para a manutenção dos vínculos familiares e sociais.

O Brasil possui uma legislação avançada em matéria de proteção dos direitos das crianças e dos adolescentes. Ademais dos direitos explícitos na Constituição Federal, no Estatuto da Criança e do Adolescente e no Código Civil (dentre outras legislações esparsas), o Brasil é signatário de tratados e convenções internacionais específicos, destinados à proteção destes seres em desenvolvimento.

Deste sistema normativo é possível extrair diversos princípios voltados à proteção das crianças, tais como: princípio do melhor interesse da criança, princípio da convivência familiar, princípio da afetividade e princípio da dignidade da pessoa humana.

A plena realização destes princípios, porém, só é possível no seio da família, seja ela natural ou substituta. 
O nosso sistema jurídico prevê que a criança deve ser mantida no seio de sua família natural, sendo a adoção medida excepcional, a ser adotada somente nos casos em que a convivência familiar for inviável. A viabilidade desta norma, por óbvio, depende não somente da boa vontade dos membros da família, como também do suporte do Poder Público, através do desenvolvimento de políticas públicas voltadas ao amparo e à assistência física, moral e financeira dos pais biológicos.

Apesar da boa vontade do nosso legislador e do investimento feito pelo Poder Judiciário para a manutenção dos vínculos biológicos (inclusive com a família estendida), fato é que em muitos casos esta convivência não se mostra possível, quer por completo descaso dos pais, quer por sua total incapacidade (até mesmo por problemas de saúde) para zelar pelos interesses de seus filhos.

Nestas hipóteses, alternativa não resta ao Poder Judiciário senão a inserção destas crianças em famílias substitutas, principalmente através da adoção.

Os dados científicos mencionados neste trabalho demonstram que a maior parte das crianças institucionalizadas no país são negras, ao passo que a maior parte dos adotantes são brancos, dado que justifica, por si só, o incentivo das adoções inter-raciais e o enfoque emprestado a esta medida no presente trabalho.

Apesar da resistência da doutrina norte-americana às adoções inter-raciais, restou demonstrado que a medida representa vantagens não apenas para os adotados, como também para os adotantes e para toda a sociedade, não configurando nenhum risco à identidade racial dos envolvidos.

Ademais de oferecer a oportunidade das crianças institucionalizadas formarem vínculos familiares contínuos e afetivos, a adoção inter-racial é a prova de que a convivência entre pessoas de raças diversas não só é possível, como extremamente valiosa.

O amor não encontra raízes na raça, mas sim no respeito pelas diferenças. Neste aspecto, a diversidade e o pluralismo são essenciais para o combate ao racismo e à discriminação, conforme bem lembrado pela professora Elizabeth Bartholet: 
(...) é possível reconhecer a importância da diferença cultural e racial sem se submeter ao separatismo. É possível celebrar a identidade racial de uma criança sem insistir que uma criança que tenha nascido com uma determinada raça viva dentro de uma comunidade racial pré-estabelecida. É possível reconhecer que existe uma enorme variedade de formas dos indivíduos de diversos grupos raciais definirem a sua identidade e os relacionamentos que mantêm com outros grupos raciais. É possível acreditar que as pessoas são plenamente capazes de amar aqueles que não são racial e biologicamente iguais, mas que são "outros", e é importante que mais pessoas aprendam a assim agir. É possível que se veja a eliminação das hostilidades raciais como mais importante que a promoção da diferença cultural.

A partir desta perspectiva, com a qual compartilho, as famílias adotivas transraciais constituem um interessante modelo de como podemos viver melhor em sociedade. Estas famílias podem dar certo apenas se existir respeito pela diferença e amor que transcenda esta diferença. E as evidências indicam que estas famílias, de fato, dão certo. Dessa maneira, eu acredito que as políticas vigentes de combinação racial devem ser abandonadas, não apenas porque violam a lei, mas porque causam sérios prejuízos às crianças negras em nome da necessidade de se promover o separatismo racial. ${ }^{297}$

Esta pesquisa não nega as dificuldades que serão enfrentadas pelos adotantes e pelos adotados que optarem pela adoção inter-racial, em razão do perfil da sociedade brasileira e da discriminação nela ainda existente, por mais mascarada que seja.

Entretanto, este estudo, baseado em experiências de adotantes e adotados, relatadas por pesquisadores das áreas das ciências sociais, demonstra que o apoio de psicólogos e de assistentes sociais, aliado à educação em direitos humanos, pode tornar a medida não apenas viável, como real. ${ }^{298}$ Para tanto, porém, é preciso que sejam reconhecidas e valorizadas as diferenças, abrindo-se as portas para um intercâmbio cultural.

297 "But one can recognize the importance of racial and cultural difference without subscribing to separatism. One can celebrate a child's race identity without insisting that the child born with a particular racial make-up must live within a prescribed racial community. One can recognize that there are an endless variety of ways individual members of various racial groups choose to define their identities and to define themselves in relationship to racial and other groups. One can believe that people are fully capable of love those who are not biological and racial likes, but are 'other', and that it is important that more learn to do so. One can see the elimination of racial hostilities as more important than the promotion of cultural difference. From this perspective, which is one I share, transracial adoptive families constitute an interesting model of how we might better learn to live with one another in this society. These families can work only if there is appreciation of racial difference. And the evidence indicates that these families do work. Accordingly, I believe that current racial matching policies should be abandoned not simply because they violate the law but because they do serious injury to clack children in the interest of promoting as inappropriate separatist agenda." (BARTHOLET, Elizabeth. Where do Black children belong? The politics of race matching in adoption. University of Pennsylvania Law Review, n. 05, vol. 139, p. 1247-48, may 1991).

298 “Através deste estudo, constatou-se que a adoção inter-racial não é uma prática muito comum na sociedade atual, nem no país, nem nas cidades catarinenses. Ela caracteriza-se como um ato possível e realizável, desde que as diferenças sejam reconhecidas pelos pais. É exatamente a aceitação dessas diferenças que permitirá aos pais levar em consideração a sua história anterior e estabelecer, junto com seu filho, um relacionamento que facilitará o seu desenvolvimento, num contexto cultural diverso daquele de origem. Numa adoção inter-racial é necessário que sejam vivenciadas e reconhecidas, positivamente, pela criança as características culturais e biológicas que ela adquiriu originalmente e, em particular, a cor de sua pele. Se 
Uma vez ultrapassadas as barreiras aqui mencionadas, a adoção inter-racial se mostra a medida mais adequada ao desenvolvimento recíproco dos adotantes e dos adotados brasileiros, trazendo consequências benéficas para toda sociedade. Isto porque, a convivência familiar contínua colabora para a formação do caráter dos indivíduos e, em última análise, previne comportamentos violentos.

Dessa maneira, a colocação de crianças em famílias substitutas, quando a convivência familiar no seio da família natural for inviável, representa importante mecanismo de prevenção da violência e da criminalidade.

Em um país no qual o sistema de repressão enfrenta uma forte crise, em razão da falta de credibilidade, da ausência de investimento e da inexistência de adoção de medidas de ressocialização, o investimento na família parece ser a aposta menos arriscada e mais confiável, em virtude da comprovação de que a convivência familiar saudável é responsável pela formação do caráter dos indivíduos.

Em suma, a conjugação dos benefícios pessoais e sociais da adoção (em especial da adoção inter-racial, em razão da realidade brasileira), narrados no decorrer do presente trabalho, demonstra que a medida deve receber especial atenção da sociedade, da família e do Poder Público, por representar importante mecanismo de desenvolvimento humano para o nosso país.

uma criança afrodescendente, adotada por pais brancos, sentir-se e for sentida como um verdadeiro membro dessa nova família, num clima recíproco de dignidade e de respeito, será o prenúncio da possibilidade de constituição de uma família mutirracial, mesmo em sociedades em que ainda são fortes os sinais e as barreiras estabelecidas entre as diferentes etnias. Esta conscientização permitirá à criança afrodescendente, adotada por pais brancos, poder mostrar-se à sociedade que tanto a discrimina e a marginaliza- ao meio extrafamiliar- não como um "hóspede" ou um "filho bastardo", mas como um real membro de uma família que é, e que pode se considerar uma família multirracial, que contribui e valorize a diversidade étnica, ressaltando a dignidade de crianças e adultos de todas as etnias" (RUFINO, Silvana. Uma realidade fragmentada: a adoção inter-racial e os desafios da formação de uma família multiracial. Florianópolis, Katálysis, v.5, n.1,p. 86, jan./jun. 2002). 


\section{REFERÊNCIAS}

ADORNO, Sergio. Exclusão socioeconômica e violência urbana. Porto Alegre, Sociologias, ano 4, no 8, pp.84-135, jul/dez 2002.

ALEXANDRINO, José de Melo. Os direitos das crianças: linhas para uma construção unitária. In TEIXEIRA, Ana Carolina Brochado et al (coords.). Problemas da Família no Direito. Belo Horizonte: Del Rey, 2012.

AOKI, Luiz Paulo Santos. Da Família Substituta. In CURY, Munir. Estatuto da Criança e do Adolescente Comentado. Comentários Jurídicos e Sociais. $12^{\mathrm{a}}$ ed. São Paulo: Malheiros, 2013.

ALMEIDA, Guilherme Assis de. Mediação, proteção local dos direitos humanos e prevenção da violência. In Revista Brasileira de Segurança Pública, ano 1, edição 2, pp. 137-138, 2007.

AULER, Juliana de Alencar. Adoção e direito à verdade sobre a própria origem. Belo Horizonte, Revista de Jurisprudência Mineira, v. 61, n. 194, pp. 23-30, jul./set 2010.

BANKS, Ralph Richard. The Color of Desire: Fulfilling Adoptive Parent's Racial Preferences Through Discriminatory State Action. 107 Yale Law Journal, pp.875-964, 1998.

BARAN, Anette; PANNOR, Reuben. Perspectives on Open Adoption. The Future of Children. Adoption, vol. 3, n.1, pp. 119-124, Spring 1993.

BARROS, Sérgio Resende de. Direitos Humanos e Direito de Família. Palestra proferida em 29/08/2003, na XII Jornada de Direito de Família, realizada no Auditório da Assembleia Legislativa do Estado do Rio Grande do Sul. Disponível em <www.srbarros.com.br>. Acesso em 09/01/2013.

BARROSO, Luis Roberto; BARCELLOS, Ana Paula de. O começo da história: a nova interpretação constitucional e o papel dos princípios no Direito Brasileiro. In SILVA, Virgílio Afonso da (org.). Interpretação Constitucional. São Paulo: Malheiros, 2005.

BARTHOLET, Elizabeth. Private Race Preferences in Family Formation. The Yale Law Journal, n. 7, vol. 107, pp.2351-2356, May 1998.

. Nobody's children. Abuse and Neglect, Foster Drift, and the Adoption Alternative. Boston: Beacon Press, 1999.

Family Bonds. Adoption, Infertility, and The New World of Child Production. Boston: Beacon Press, 1999.

Where do Black children belong? The politics of race matching in adoption. University of Pennsylvania Law Review, n. 05, vol. 139, pp.1163-1256, may 1991. 
BECKER, Maria Josefina. Da Adoção. In CURY, Munir. Estatuto da Criança e do Adolescente Comentado. Comentários Jurídicos e Sociais. $12^{\mathrm{a}}$ ed. São Paulo: Malheiros, 2013.

BELLI, Benoni. A politização dos Direitos Humanos. O Conselho de Direitos Humanos das Nações Unidas e as Resoluções sobre países. São Paulo: Perspectiva, 2009.

BERIAIN, Miguel. Es digno ser un ser que no es autónomo? Reflexiones acerca del concepto kantiano de dignidad humana. In Estudios en Homenaje al Profesor Gregorio Peces-Barba. Madrid: Dykinson, 2008.

BERMAN, Harold J. Direito e Revolução. A Formação da Tradição Jurídica Ocidental. São Leopoldo: Unisinos, 2006.

BERRY, Marianne. Risks and Benefits of Open Adoption. The Future of Children. Adoption, vol. 3, n.1, p. 125-138, Spring 1993.

BITTENCOURT, Sávio. A Nova Lei de Adoção. Do Abandono à Garantia do Direito à Convivência Familiar e Comunitária. Rio de Janeiro: Lumen Jures, 2010.

BLACKBURN, Robin. A Queda do Escravismo Colonial: 1776-1848. Rio de Janeiro: Record, 2002.

BOBBIO, Norberto. A Era dos Direitos. Rio de Janeiro: Elsevier, 2004.

BOCHNIA, Simone Franzoni. Da Adoção. Categorias, Paradigmas e Práticas de Direito de Família. Curitiba: Juruá, 2010.

BOSCHI, Fábio Bauabi. Direito de Visita. São Paulo: Saraiva, 2006.

BONAVIDES, Paulo. Curso de Direito Constitucional. 28 ed. São Paulo: Malheiros, 2013.

BOULOS, Kátia. Da Guarda "Com-Parte-lhada" à Guarda Compartilhada: Novos Rumos e Desafios. In SILVA, Regina Beatriz Tavares da; CAMARGO NETO, Theodureto de Almeida. Grandes Temas de Direito de Família e das Sucessões. São Paulo: Saraiva, 2011.

BRASIL. Comitê Nacional de Educação em Direitos Humanos. Plano Nacional de Educação em Direitos Humanos. Brasília: Secretaria Especial dos Direitos Humanos, 2007.

CANÇADO TRINDADE, Antônio Augusto. A Humanização do Direito Internacional. Belo Horizonte: Del Rey, 2006.

CANDAU, Vera Maria. Direitos humanos, educação e interculturalidade: as tensões entre igualdade e diferença. Revista Brasileira de Educação, v. 13, n. 37, pp. 45-56, jan./abr. 2008.

CARBONERA, Silvana Maria. Guarda de filhos na família constitucionalizada. Porto Alegre: Sergio Antonio Fabris Editor, 2000. 
CARVALHO, Márcia Lopes de; FRANCO, Natalia Soares. O cuidado na adoção: algumas experiências. In PEREIRA, Tânia da Silva e OLIVEIRA, Guilherme de (coords.). $O$ cuidado como valor jurídico. Rio de Janeiro: Forense, 2008.

CARVALHO RAMOS, André. Teoria Geral dos Direitos Humanos na Ordem Internacional. $2^{\mathrm{a}}$ ed. São Paulo: Saraiva, 2012.

A Interpretação Internacional dos Direitos Humanos: Choque ou Diálogo com o Supremo Tribunal Federal? In BAPTISTA, Luiz Olavo; FERRAZ JUNIOR, Tércio Sampaio (coords.). Novos Caminhos do Direito no Século XXI. Direito Internacional, Filosofia Jurídica e Política, Dogmática Jurídica e Direitos Fundamentais. Uma Homenagem a Celso Lafer. Curitiba: Juruá, 2012.

COMPARATO, Fábio Konder. A Afirmação Histórica dos Direitos Humanos. $4^{\mathrm{a}}$ edição. São Paulo: Saraiva, 2005.

Ética. Direito, Moral e Religião no Mundo Moderno. $3^{\text {a }}$ ed. São Paulo: Companhia das Letras, 2011.

Fundamentos dos Direitos Humanos. São Paulo: Instituto de Estudos Avançados da Universidade de São Paulo, 1997, p. 19. Texto disponível em <www.iea.usp.br/artigos>. Acesso em 19/03/2012.

CURY, Munir (coord). Estatuto da Criança e do Adolescente Comentado. Comentários Jurídicos e Sociais. 12a ed. São Paulo: Malheiros, 2012.

DALLARI, Pedro Bohomoletz de Abreu. Tratados Internacionais na Emenda Constitucional 45. In TAVARES, André Ramos et al (coord.). Reforma do Judiciário analisada e comentada. São Paulo: Método, 2005.

DALLARI, Dalmo de Abreu. Elementos da Teoria Geral do Estado. 25 a ed. São Paulo: Saraiva, 2003.

DIAS, Adelaide Alves. Da educação como direito humano aos direitos humanos como princípio educativo. In SILVEIRA, Rosa Maria Godoy et al (org.). Educação em Direitos Humanos. Fundamentos teórico-metodológicos. João Pessoa: Editora Universitária da UFPB, vol. 1, 2007.

DIMOULIS, Dimitri; MARTINS, Leonardo. Definição e características dos direitos fundamentais. In LEITE, George Salomão; SARLET, Ingo Wolfgang (Org.). Direitos Fundamentais e Estado Constitucional. Estudos em Homenagem a J.J. Gomes Canotilho. Coimbra: Coimbra Editora, 2009.

DOLINGER, Jacob. Direito Internacional Privado. A Criança no Direito Internacional. Rio de Janeiro: Renovar, 2003.

DOLTO, Françoise. Destinos de crianças: adoção, famílias de acolhimento, trabalho social. São Paulo: Martins Fontes, 1998. 
DONNELLY, Jack. Cultural Relativism and Universal Human Rights. In Human Rights Quarterly, vol. 6, nº 4, pp. 400-419, 1994.

FERREIRA FILHO, Manoel Gonçalves. Curso de Direito Constitucional. 24 ed. São Paulo: Saraiva, 1997.

FERREIRA, Lúcia Maria Teixeira; BITTENCOURT, Sávio Renato. A adoção no início do terceiro milênio: para cada criança uma família - primeiros questionamentos. In PEREIRA, Tânia da Silva; OLIVEIRA, Guilherme de. Cuidado e vulnerabilidade. São Paulo: Atlas, 2009.

FONSECA, Antônio Cezar Lima da. Direitos da Criança e do Adolescente. $2^{\text {a }}$ ed. São Paulo: Atlas, 2012.

FRANCISCO, José Carlos. Bloco de Constitucionalidade e Recepção dos Tratados Internacionais. In TAVARES, André Ramos; LENZA, Pedro; ALARCÓN, Pietro de Jesús. Reforma do Judiciário analisada e comentada. São Paulo: Método, 2005.

GADOTTI, Moacir. A questão da educação formal/ não-formal. Disponível em <www.virtual.ufc.br>. Acesso em 15/01/2014.

GALBRAITH, J.K. The Affluent Society. Fortieth Anniversary Edition. Boston: Mariner Books, 1998.

GAMA, Guilherme Calmon Nogueira da. Princípios Constitucionais do Direito de Família. Guarda Compartilhada à Luz da Lei $n^{\circ}$ 11.698/08: família, criança, adolescente e idoso. São Paulo: Atlas, 2008.

Cuidado e Planejamento Familiar. In PEREIRA, Tânia da Silva e OLIVEIRA, Guilherme de. Cuidado e Vulnerabilidade. São Paulo: Atlas, 2009.

GENEVOIS, Margarida Pedreira Bulhões. Educação e Direitos Humanos. Disponível em <www.dhnet.org.br/educar/textos/genevois_edh.pdf>. Acesso em 15/01/2014.

GOMES, Maria Tereza Uille. Direitos Humanos, Desenvolvimento e os Objetivos de Desenvolvimento do Milênio (ODM). In FOLMANN, Melissa; ANNONI, Daniela. Direitos Humanos: Os 60 Anos da Declaração Universal da ONU. Curitiba: Juruá Editora, 2008. pp. 265-282.

HIRONAKA, Giselda; MÔNACO, Gustavo Ferraz de Campos. Síndrome de Alienação Parental. In TEIXEIRA, Ana Carolina Brochado et al (coords.). Problemas da Família no Direito. Belo Horizonte: Del Rey, 2012. pp. 235-247.

HONNETH, Axel. A Luta por Reconhecimento. A gramática moral dos conflitos sociais. São Paulo: Editora 34, 2009.

IKAWA, Daniela. Direito às Ações Afirmativas em Universidades Brasileiras. In SARMENTO, Daniel; IKAWA, Daniela; PIOVESAN, Flávia. Igualdade, Diferença e Direitos Humanos. Rio de Janeiro: Lumen Juris, 2010. 
INSTITUTO DE PESQUISA ECONÔMICA AVANÇADA- IPEA. Levantamento nacional dos abrigos para crianças e adolescentes da rede de Serviço de Ação Continuada (SAC). Relatório de Pesquisa n.01, Brasília: IPEA, 2003.

KANT, Immanuel. Fundamentação da Metafísica dos Costumes. Rio de Janeiro: Edições 70 Brasil, 1991.

LAFER, Celso. A Internacionalização dos Direitos Humanos: O Desafio do Direito a Ter Direitos. Revista do Tribunal Regional Federal da $3^{a}$ Região, vol. 75, pp. 44-45, jan. e fev./2006.

. Declaração Universal dos Direitos Humanos (1948). In MAGNOLI, Demétrio (org.). História da Paz. São Paulo: Contexto, 2008.

Direitos Humanos em Hannah Arendt: Considerações sobre as Fontes Materiais da Declaração Universal de 1948. São Paulo, Justitia, n. 65, p. 113, jan./jun. 2008.

. Liberdade e Igualdade: Reflexões sobre o crescimento econômico e a democracia. In__. Ensaios sobre a liberdade. São Paulo: Perspectiva, 1980.

- A Declaração Universal dos Direitos Humanos - Sua Relevância para a Afirmação da Tolerância e do Pluralismo. In MARCílIO, Maria Luiza et al (org.). A Declaração Universal dos Direitos Humanos. Sessenta Anos. Sonhos e Realidades. São Paulo: Editora da Universidade de São Paulo, 2008.

LEITE, Eduardo de Oliveira. Estudos de Direito de Família e Pareceres de Direito Civil. Em homenagem à Dra. Regina Bilac Pinto, a "Grande Dama" da editoração jurídica brasileira. Rio de Janeiro: Forense, 2011.

LINDGREN ALVES, José Augusto. No Peito e na Raça: a Americanização do Brasil e a brasilianização da América. Revista Impulso, n. 27, pp. 133-156, set./2000.

. O Multiculturalismo Ideológico: Defeitos de uma Ideia Bem-Intencionada para Combater o Racismo. In PIOVESAN, Flávia e IKAWA, Daniela (coord). Direitos Humanos: Fundamento, Proteção e Implementação. Perspectivas e Desafios Contemporâneos. Curitiba: Juruá, 2009. v. II

LOBO, Ana Maria Lima. Os Maus-Tratos na Infância e Adolescência. Aspectos Jurídicos. In PIOVESAN, Flávia e IKAWA, Daniela. Direitos Humanos: Fundamento, Proteção e Implementação. Perspectivas e Desafios Contemporâneos. Curitiba: Juruá, 2009. v. II

MADALENO, Rolf. Novas Perspectivas do Direito de Família. Porto Alegre: Livraria do Advogado, 2000.

A guarda compartilhada pela ótica dos direitos fundamentais. In WELTER, Belmiro Pedro; MADALENO, Pedro Hanssen. Direitos Fundamentais do Direito de Família. Porto Alegre: Livraria do Advogado, 2004.

MALUF, Adriana Caldas do Rego Freitas Dabus. Direito das famílias. Amor e bioética. Rio de Janeiro: Elsevier, 2012. 
MARTEL, Letícia de Campos Velho. São os Direitos Fundamentais Disponíveis? Reflexões à Luz da Teoria dos Direitos de Robert Alexy. In __. Estudos Contemporâneos de Direitos Fundamentais. Rio de Janeiro: Lumen Juris, 2009. V1 II, pp. 43-69.

MAZZUOLI, Valerio de Oliveira. Curso de Direito Internacional Público. $7^{\mathrm{a}}$ ed. São Paulo: Revista dos Tribunais, 2013.

- Teoria geral do controle de convencionalidade no direito brasileiro. In PIOVESAN, Flávia et al (coord.). Estudos Avançados de Direitos Humanos. Democracia e Integração Jurídica: Emergência de um novo Direito Público. Rio de Janeiro: Elsevier, 2013.

Saraiva, 2010.

Tratados Internacionais de Direitos Humanos e Direito Interno. São Paulo:

Direitos Humanos, Constituição e os Tratados Internacionais. Estudo analítico da situação e aplicação do Tratado na Ordem Jurídica Brasileira. São Paulo: Juarez de Oliveira, 2001.

MÔNACO, Gustavo Ferraz de Campos. A Proteção da Criança no Cenário Internacional. Belo Horizonte: Del Rey, 2005.

- Motivação interna da decisão de adotar: adoção por casais e por pessoas singulares. Porto Alegre, Revista Brasileira de Direito de Família, v. 4, n. 14, pp. 43-50, 2002.

MÔNACO, Gustavo Ferraz de Campos; CAMPOS, Maria Luiza Ferraz de. O direito de audição de crianças e jovens em processo de regulação do exercício do poder familiar. Curitiba: Arte Jurídica: Biblioteca Científica de Direito Civil e Processo Civil da Universidade Estadual de Londrina, 2006. v. 3, pp. 93-105.

MORAES, Alexandre de. Direito Constitucional. 30ª ed. São Paulo: Atlas, 2014.

MORRISON, Andrew. Transracial Adoption: The Pros and Cons and The Parent's Perspective. Harvard BlackLetter Law Journal, vol. 20, pp.163-202, 2004.

OLIVEIRA, José Sebastião de. Fundamentos Constitucionais do Direito de Família. São Paulo: Revista dos Tribunais, 2002.

OlIVEIRA E TELlES, Marília Campos; COLTRO, Antônio Carlos Mathias. Cuidando do cuidado. In PEREIRA, Tânia da Silva; OLIVEIRA, Guilherme de. Cuidado e Vulnerabilidade. São Paulo: Atlas, 2009.

OMS. Organização Mundial de Saúde. Relatório mundial sobre a violência e saúde. s.l., 2002.

ONU. Programa das Nações Unidas para o Desenvolvimento. Relatório de Desenvolvimento Humano Brasileiro 2005. Brasília: PNUD, 2006. 
Programa das Nações Unidas para o Desenvolvimento. Relatório de Desenvolvimento Humano Brasileiro 2009/2010. Brasília: PNUD, 2010.

PELUSO, Antônio Cézar. Da Colocação em Família Substituta. In CURY, Munir (coord.). Estatuto da Criança e do Adolescente Comentado. Comentários Jurídicos e Socais. $12^{\mathrm{a}}$ ed. São Paulo: Malheiros, 2013.

PEREIRA, Rodrigo da Cunha. Princípios Fundamentais Norteadores do Direito de Família. Belo Horizonte: Del Rey, 2006.

PICO DELLA MIRÀNDOLA, Giovanni. Discurso sobre a dignidade do homem. Tradução de Maria de Lurdes Sirgado Ganho. Lisboa: Edições 70, 2001.

PIOVESAN, Flávia. Direitos Humanos e Diálogo Jurisdicional no Contexto Latinoamericano. In BOGDANDY, Arminvon; PIOVESAN, Flávia; ANTONIAZZI, Mariela Morales. Estudos Avançados de Direitos Humanos. Democracia e Integração Jurídica: Emergência de um Novo Direito Público. Rio de Janeiro: Elsevier, 2013.

Temas de Direitos Humanos. $4^{\mathrm{a}}$ ed. São Paulo: Saraiva, 2010.

- Direitos Humanos: Desafios da Ordem Internacional Contemporânea. In PIOVESAN, Flávia (coord.). Direitos Humanos. Curitiba: Juruá, 2009. V1 I.

Direito Internacional dos Direitos Humanos e Igualdade Étnico-Racial. In SOUZA, Douglas Martins de; PIOVESAN, Flávia. Ordem Jurídica e Igualdade ÉtnicoRacial. Rio de Janeiro: Lumen Juris, 2008.

Igualdade, diferença e direitos humanos: perspectivas global e regional. In LEITE, George Salomão; SARLET, Ingo Wolfgang (Org.). Direitos Fundamentais e Estado Constitucional. Estudos em Homenagem a J.J. Gomes Canotilho. Coimbra: Coimbra Editora e Revista dos Tribunais, 2009.

Direitos Humanos, o Princípio da Dignidade Humana e a Constituição Brasileira de 1988. In Revista dos Tribunais, vol. 94, p. 52, mar./2005.

Reforma do Judiciário e Direitos Humanos. In TAVARES, André Ramos; LENZA, Pedro; ALARCÓN, Pietro de Jesús Lora (coords.). Reforma do Judiciário: analisada e comentada. São Paulo: Método, 2005.

PRUDENTE, Eunice Aparecida de Jesus. Educação em Direitos: Um Caminho para a Igualdade Racial. In Revista Brasileira de Filosofia, ano 60, n. 236, pp. 35-72, jan.jun./2011.

REZEK, José Francisco. Direito Internacional Público: curso elementar. $8^{a}$ ed. São Paulo: Saraiva, 2000.

RIBEIRO, Paulo Hermano Soares; SANTOS, Vívian Cristina Maria; SOUZA, Ionete de Magalhães. Nova Lei de Adoção Comentada. $2^{a}$ ed. Leme: J.H.Mizuno, 2012. 
RICHTER, Daniela; VIEIRA, Gustavo Oliveira; TERRA, Rosane Mariano da Rocha Barcelos. A Proteção Internacional da Infância e Juventude: Perspectivas, Contextos e Desafios. In PES, João Hélio Ferreira (coord.). Direitos Humanos: Crianças e Adolescentes. Curitiba: Juruá, 2010.

RICOEUR, Paul. Violência e Linguagem. Leituras 1: Em torno ao Político. São Paulo: Edições Loyola, 1995.

ROCHA, Carmen Lúcia Antunes. O Princípio da Dignidade da Pessoa Humana e a Exclusão Social. Fortaleza, Revista do Instituto Brasileiro de Direitos Humanos, ano 2, vol. 2, número 2, pp. 49-67, 2001.

RUFINO, Silvana. Uma realidade fragmentada: a adoção inter-racial e os desafios da formação de uma família multiracial. Florianópolis, Katálysis, v.5, n.1, pp. 79-88, jan./jun. 2002.

SALOMÃO FILHO, Calixto; FERRÃO, Brisa Lopes de Mello; RIBEIRO, Ivan César. Concentração, Estruturas e Desigualdade: As origens coloniais da pobreza e da má distribuição de renda. São Paulo: Idcid, 2006.

SAMUELS, Gina Miranda. Being Raised by White People: Navigating Racial Difference Among Adopt Multiracial Adults. In Journal of Marriage and Family 71, p. 81, February 2009.

SANTOS, Boaventura de Souza. Para uma Concepção Intercultural dos Direitos Humanos. In SARMENTO, Daniel et al (coord). Igualdade, Diferença e Direitos Humanos. Rio de Janeiro: Lumen Juris, 2010.

SANTOS, Romualdo Baptista dos. A Tutela Jurídica da Afetividade. Curitiba: Juruá, 2011.

SARLET, Ingo Wolfgang. Os direitos sociais como direitos fundamentais: seu conteúdo, eficácia e efetividade no atual marco jurídico-constitucional brasileiro. In LEITE, George Salomão; SARLET, Ingo Wolfgang (Org.). Direitos Fundamentais e Estado Constitucional. Estudos em Homenagem a J.J. Gomes Canotilho. Coimbra: Coimbra Editora, 2009.

Dignidade da Pessoa Humana e Direitos Fundamentais na Constituição Federal de 1988. 4ª ed. Porto Alegre: Livraria do Advogado, 2006.

SARMENTO, Daniel. Direito Constitucional e Igualdade Étnico-Racial. In PIOVESAN, Flávia; SOUZA, Douglas Martins de. Ordem Jurídica e Igualdade Étnico-Racial. Rio de Janeiro: Lumen Juris, 2008.

SECRETARIA MUNICIPAL DE ASSISTÊNCIA SOCIAL - SAS [et al.] (2004). Reordenamento de abrigos infanto-juvenis da cidade de São Paulo: construção da política interinstitucional de defesa dos direitos de convivência familiar e comunitária das crianças e adolescentes de São Paulo. São Paulo: SAS, 2004.

SEN, Amartya. Desenvolvimento como Liberdade. São Paulo: Companhia das Letras, 2000 . 
SILVA, José Afonso da. Curso de Direito Constitucional Positivo. $37^{\mathrm{a}}$ ed. São Paulo: Malheiros, 2014.

. Mandado de Segurança. 28 ed. São Paulo: Malheiros, 2005.

SILVA, Sávio Renato Bittencourt Soares. Guia do Pai Adotivo. Orientações para uma Adoção Feliz. $2^{a}$ ed. Curitiba: Juruá, 2012.

SILVERMAN, Arnold R. Outcomes of Transracial Adoption. The Future of Children. Adoption, n. 1, vol. 3, Spring, pp.104-118, 1993.

SZNICK, Valdir. Adoção. Direito de Família, Guarda de Menores, Tutela, Pátrio Poder, Adoção Internacional. $3^{a}$ ed. São Paulo: Liv. e Ed. Universitária de Direito, 1999.

TAKAHASHI, Estela Mayumi. A adoção no Brasil. In SILVA, Regina Beatriz Tavares da; CAMARGO NETO, Theodureto de Almeida Camargo. Grandes Temas de Direito de Família e das Sucessões. São Paulo: Saraiva, 2011.

TAVARES, André Ramos. Princípio da Dignidade da Pessoa Humana. In ARAÚJO, Luiz Alberto David; SEGALLA, José Roberto Martins (coords.). 15 anos da Constituição Federal em busca da efetividade. Bauru: EDITE, 2003.

VERONESE, Josiane Rose Petry. Discriminação e atentados ao exercício da cidadania da criança e do adolescente. In PEREIRA, Tânia da Silva (coord). O Melhor Interesse da Criança: Um Debate Interdisciplinar. Rio de Janeiro: Renovar, 1999.

VIEIRA, Oscar Vilhena. A Desigualdade e a Subversão do Estado de Direito. In SARMENTO, Daniel et al (coord.). Igualdade, Diferença e Direitos Humanos. Rio de Janeiro: Lumen Juris, 2010. pp.191-216.

WEBER, Lidia Natalia Dobrianskyj. Aspectos Psicológicos das Famílias por Adoção. In LEITE, Eduardo de Oliveira (org.). Grandes Temas da Atualidade: Adoção. Aspectos Jurídicos e Metajurídicos. Rio de Janeiro: Forense, 2005.

Aspectos Psicológicos da Adoção. $2^{\mathrm{a}}$ ed. Curitiba: Juruá, 2011.

Prefácio. In SOUZA, Hália Pauliv de. Adoção Tardia. Devolução ou Desistência de um Filho? A Necessária Preparação para a Adoção. Curitiba: Juruá, 2012.

Quero que alguém me chame de filho: abandono, pobreza, institucionalização e o direito à convivência familiar. $\quad$ Disponível $<$ http//lidiaw.sites.uol.com.br/convivenciafamiliar.htm>. Acesso em 12/01/2013.

WEINGARTNER NETO, Jayme; SARLET, Ingo Wolfgang. Dignidade (da Pessoa) Humana e Fundamentais e Ensino Jurídico: Algumas Aproximações. In NALINI, José Renato e CARLINI, Angélica. Direitos Humanos e Formação Jurídica. Rio de Janeiro: Forense, 2010.

WINNICOTT, Donald W. A família e o desenvolvimento individual. Trad. de Marcelo Brandão Cipola. São Paulo: Martins Fontes, 1983. 